\title{
Over keuringen. Onderzoek naar de kwaliteit van keuringen voor militair personeel van de Koninklijke Landmacht
}

Citation for published version (APA):

de Raad, J. (2005). Over keuringen. Onderzoek naar de kwaliteit van keuringen voor militair personeel van de Koninklijke Landmacht. [Doctoral Thesis, Maastricht University]. https://doi.org/10.26481/dis.20050916jr

Document status and date:

Published: 01/01/2005

DOI:

10.26481/dis.20050916jr

Document Version:

Publisher's PDF, also known as Version of record

\section{Please check the document version of this publication:}

- A submitted manuscript is the version of the article upon submission and before peer-review. There can be important differences between the submitted version and the official published version of record.

People interested in the research are advised to contact the author for the final version of the publication, or visit the DOI to the publisher's website.

- The final author version and the galley proof are versions of the publication after peer review.

- The final published version features the final layout of the paper including the volume, issue and page numbers.

Link to publication

\footnotetext{
General rights rights.

- You may freely distribute the URL identifying the publication in the public portal. please follow below link for the End User Agreement:

www.umlib.nl/taverne-license

Take down policy

If you believe that this document breaches copyright please contact us at:

repository@maastrichtuniversity.nl

providing details and we will investigate your claim.
}

Copyright and moral rights for the publications made accessible in the public portal are retained by the authors and/or other copyright owners and it is a condition of accessing publications that users recognise and abide by the legal requirements associated with these

- Users may download and print one copy of any publication from the public portal for the purpose of private study or research.

- You may not further distribute the material or use it for any profit-making activity or commercial gain

If the publication is distributed under the terms of Article $25 \mathrm{fa}$ of the Dutch Copyright Act, indicated by the "Taverne" license above, 


\section{OVER KEURINGEN}

Onderzoek naar de kwaliteit van keuringen voor militair personeel van de Koninklijke Landmacht 
ISBN 9052784795

Copyinght $O$ John de Rad, Mastricht 2005

Vormgeving en druk: Datawyse / Unversitaire Pers Maastricht

Onslag: Invaliden te Bronbeek, 1897 door J.W. Hoijinck wan Papendrecht. 


\section{OVER KEURINGEN}

Onderzoek naar de kwaliteit van keuringen voor militair personeel van de Koninklijke Landmacht

\section{PROEFSCHRIFT}

ter verkrijging van de graad van doctor aan de Universiteit Maastricht, op gezag van de Rector Magnificus, Prof. mr. G.P.M.F. Mols volgens het besluit van het College van Decanen, in het openbaar te verdedigen op vrijdag 16 september 2005 om 14.00 uur door

John de Raad

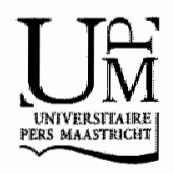


Promolores

Prof. dr. FIN. Nujhuis

Prof. dr. J.H.B.M. Willems (Universiteit van Amsterdam)

\section{Beoordelingscommissie}

Prof. mr. dr. Fu van Wigmen, voorzitter

Prof. dr. J. Th. M. van Eijk

Prof. dr. J.W. Groothoff (Rijksuniversiteit Groningen).

Dr. W.L.A.M. de Kort (Divisiedirecteur Sanquin Bloedbank Regio Zuidoost) Dr. A. de Rijk 
18. Want geen man, in wien een gebrek zal zijn, zal naderen om de spijze van zijn God te offeren, hij zij een blind man, of kreupel, of te kort of te lang in leden;

19. Of een man, in wien een breuk des voets, of een breuk der hand zal zijn;

20. Of die bultachtig, of dwergachtig zal zijn, of een vel op zijn oog zal hebben, of droge schurftheid, of etterige schurftheid, of die gebroken zal zijn aan zijn gemacht.

Levitias, vers 21, Statenvertaling 1959. 


\section{Inhoudsopgave}

1. Inleiding en vraagstelling 11

1.1 Achtergrond van het onderzoek $\quad 12$

1.2 Niet systematische waarnemingen 12

1.3 Systematische waarnemingen 14

1.4 Een nieuw keuringssysteem en de relatie erwan met $\begin{array}{ll}\text { wet- en regelgeving } & 28\end{array}$

1.5 Theorie, hypothese en vraagstelling 39

1.6 Material en methoden 51

1.7. Verdere uitwerking van het onderzoek

2. De beperkingen van medische beperkingen 65

2.1 Inleiding en vraagstelling van dit onderzoek 66

2.2 Achtergrondinformatie 66

2.3 Materiaal en methoden 68

2.4 Resultaten 71

2.5 Beschouwing 75

3. Een onderzoek naar de reproduceerbaarheid van de basismedische eisen KL bij de pensioenkeuring 79

3.1 Inleiding en vraagstelling van het onderzoek 80

3.2 Materiaal en methoden 81

3.3 Resultaten $\quad 83$

3.4 Beschouwing 86

4. De reproduceerbaarheid van de aanstellingskeuring op grond van de Basismedische eisen en het ABOHZISsysteem

4.1 Inleiding en vraagstelling van dit onderzoek 92

4.2 Achtergrondinformatie 93

4.3 Material en methoden 94

4.4 Resultaten 96

4.5 Beschouwing 99 
5. Een vergelijking tussen twee systemen voor de aanstellingskeuring bij de Koninklijke Landmacht met behulp van een gerandomiseerde, gecontroleerde studie

5.1 Inleiding en vraagstelling van dit onderzoek 106

5.2 Material en methoden 108

$\begin{array}{ll}5.3 \text { Resultaten } & 110\end{array}$

5.4 Beschouwing 115

6. Analyse van het verschil in prognostische waarde tussen beide keuringssystemen

6.1 Inleiding en vraagstelling voor dit onderzoek. 120

6.2 Materiaal en methoden 121

$\begin{array}{ll}6.3 \text { Resultaten } & 125\end{array}$

6.4 Beschouwing 1.30

7. Verschillen in inzetbaarheid tussen uitgezonden militairen 135

7.1 Inleiding en vraagstelling voor dit onderzoek 136

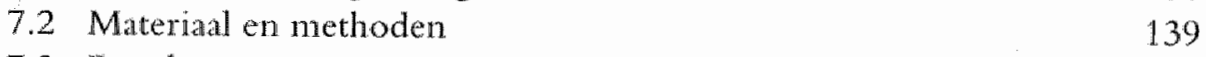

$\begin{array}{ll}7.3 \text { Resultaten } & 143\end{array}$

$\begin{array}{ll}7.4 \text { Beschouwing } & 147\end{array}$

8. Slotbeschouwing $\quad 151$

8.1 Inleiding 152

8.2 Nabeschouwing van het verrichte onderzoek 1.52

8.3 Beantwoording van de vraagstelling 156

8.4 Toetsing van de hypothese 159

8.5 Aanpassing van de theorie? 160 8.6 Over keuringen: de betekenis van dit onderzoek voor de
empirische spiraal 
Bijlage: Verklaring van begrippen en afkortingen

Samenvatting

Abstract

Nawoord

Curriculum Vitae 
1 Inleiding en vraagstelling 


\subsection{Achtergrond van het onderzoek}

Basis van dit onderzoek is de behoefte om de inzetbaarheid van militairen goed te kunnen voorspellen. De keuze voor het verrichten van onderzoek naar valide instrumentatrium is voortgekomen uit een aantal niet-systematische waarnemingen. Deze niet-systematische waarnemingen hebben geleid tot onderzoeksvragen, met als doel om meer inzicht te krijgen in de aspecten die bijdragen tot een verantwoord instrumentarium. Uitgaande van bestaand instrumentarium is een nieuw toetsingsinstrument ontwikkeld om de inzetbaarheid van militairen mee te beoordelen. Daarmee is dit onderzoek naar de voorspelbaarheid van medische keuringen primair een valideringsonderzoek [1] geworden.

In dit proefschrift worden de aanleiding, uitvoering en interpretatie van een onderzoek naar de kwaliteit van de medische aanstellingskeuring bij de Koninklijke Landmacht (KL) beschreven. Daarbij wordt uitgegaan van een onderzoeksmodel dat vergelijkbaar is met het model van de empirische cyclus [1]. Hieronder volgt allereerst de weergave van twee niet-systematische waarnemingen, die beide aanleiding vormden voor verder onderzoek. Hierna wordt aandacht besteed aan systematische waarnemingen, die mede hebben geleid tot de ontwikkeling van een nieuw keuringssysteem, waaraan aandacht zal worden besteed. Vervolgens wordt aan de waarnemingen een theorie ontleend, waaruit met inachtneming van het nieuwe keuringssysteem een hypothese wordt gededuceerd. Dan volgt het formuleren van de onderzoeksvragen, gericht op de validering van de keuringssystematiek. Aansluitend vindt een beschrijving van materiaal en methoden plaats.

Het tweede hoofdstuk is de weergave van de primaire reactie op beide niet-systematische waarnemingen, in de vorm van een eerste eigen onderzoek. In de daaropvolgende hoofdstukken wordt separaat ingegaan op de geformuleerde onderzoeksvragen. Het afsluitende hoofdstuk begint met de nabeschouwing op de verrichte onderzoeken, waarna de onderzoeksvragen worden beantwoord, gevolgd door de toetsing van de hypothese. Uiteindelijk wordt de vraag beantwoord of de nieuw ontwikkelde keuringssystematiek een valide instrument is om de inzetbaarheid van militairen te beoordelen en wordt andacht besteed aan de vraag op welk vervolg-onderzoek op het terrein van keuringen resteert.

\subsection{Niet systematische waarnemingen}

De eerste niet-systematische waarneming vond plaats tijdens het $24^{e}$ Internationale Congres voor Bedrijfsgezondheidszorg te Nice in 1993. Post-Uiterweer [2] hicld tijdens dat congres een lezing over onderzoek naar de reproduceer- 
baarheid van aanstellingskeuringen. Hij had 180 geanonimiseerde keuringsdossiers, waarvan de ene helft geschikt was verklaard en de andere helft ongeschikt, ter herbeoordeling aan vijf artsen van de bedrijfsgezondheidszorgdienst voor owerheidspersoneel (RBB) voorgelegd. De bij dit onderzoek gevonden mate van overeenkomst viel lager uit dan wat als aanvaardbare ondergrens voor screeningstesten wordt aangehouden [1]. Omdat in Frankrijk het uitvoeren van (aanstellings-, periodieke) keuringen een prominente plats binnen de bedrijfsgezondheidszorg inneent, alsmede omdat de meerderheid der toehoorders uit het gastland afkomstig bleek, leidde het bekend stellen van de onderzoeksresultaten tot uitgebreide discussie met publieke inmenging. Deze waarneming leidde enerzijds tot de constatering dat er maatstaven bestonden on de kwaliteit van keuringen te beoordelen, anderzijds tot het vermoeden dat vele keurend artsen niet van deze maatstaven op de hoogte waren.

Interesse naar de vraag hoe de mate van overeenstemming van binnen de $\mathrm{KL}$ verrichte keuringen zou zijn, ontstond pas later. Daarvoor moest eerst een tweede niet-systematische waarneming worden gedaan.

Deze tweede waarneming vond plaats tijdens een reorganisatieproject bij de $\mathrm{KL}$ in 1994. De dienstplicht werd opgeschort, er zou een beroepsleger worden gevormd en de taakstelling werd uitgebreid met het uitvoeren van missies buiten de eigen landsgrenzen. De samenstelling van het functiebestand van het toenmalige beroepskader was te onevenwichtig voor de directe omvorming tot een beroepsleger. Bovendien waren bij enige duizenden beroepsmilitairen medische en/of functioneringsbeperkingen in hun personeelsdossier opgenomen. Op grond van dat laatste feit veronderstelde de KL-leiding dat deze militairen, zeker met de uit te breiden taakstelling in het vooruitzicht, als beperkt inzetbaar moesten worden beschouwd en derhalve als eersten voor ontslag in aanmerking zouden komen.

Die medische en/of functioneringsbeperkingen werden vastgesteld naar aanleiding van het "Periodiek Geneeskundig Onderzoek" (PGO). Dit PGO was een formele periodieke toetsing an de medische dienstgeschiktheid voor beroepspersoneel. Vermindering van die geschiktheid kon leiden tot een beperking of tot ongeschikt verklaring. Op de beoordeling van militaire dienstgeschiktheid en het $\mathrm{PGO}$ wordt in paragraaf 1.3 nader ingegaan.

De staf van de Geneeskundige Dienst KL kreeg de opdracht om aan de hand van deze keuringsdossiers een uitspraak te doen omtrent de "algemene en brede inzetbaarheid" van militairen met beperkingen in hun personeelsdossier.

Bij toetsing van de keuringsdossiers kwamen twee knelpunten aan het licht. Ten eerste bleken de in de keuringsdossiers weergegeven beperkingen sterk risicowerend van aard te zijn; er was zelden sprake van een causaal verband urssen de gesignaleerde medische problemen en de actuele inzetbaarheid. Het gevolg 
daarvan was discrepantie tussen de administratieve inzetbaarheid van vele militairen en hun effectieve inzetbaarheid. Onder de geschetste omstandigheden gingen vele militairen met succes in bezwaar tegen de opgelegde beperkingen. In de tweede plaats bleek de intra-waarnemers variatie tijdens de herbeoordeling van deze dossiers hoog te liggen.

Deze warnemingen vormden de aanleiding om het door Post-Uiterweer verrichte onderzoek [2] binnen de KL te herhalen (Hoofdstuk 2). Het gegeven dat het gehanteerde keuringssysteem op een zo risicowerende manier kon worden gehanteerd vormde de aanleiding om het militaire keuringssysteem nader te beschouwen.

\subsection{Systematische waarnemingen}

\subsubsection{Beschouwing van het Militair Keuringsreglement en de lijst van ziekten en gebreken}

In 1810 was Holland door Napoleon Bonaparte bij het Franse Keizerrijk ingelijfd. Tot 1810 bestonden de Napoleontische legers geheel uit vrijwillig dienend beroepspersoneel, maar in 1811 ontstond een tekort aan vrijwilligers. Daarom voerde Napoleon in 1811 de conscriptie in - een beperkte vorm van dienstplicht [3].

Voorafgaand aan het in dienst treden van deze dienstplichtigen werd de vaststelling van hun medische geschiktheid noodzakelijk geacht. Dit was de reden waarom ook in ons land het eerste (Franse) reglement op het geneeskundig onderzoek van miliciens van kracht werd. Dit reglement vormt de grondslag van het Militair Keuringsreglement (MKR), dat sedertdien bij de Koninklijke Landmacht als basis dient voor zowel de medische aanstellingskeuring als de pensioenkeuring voor militair personeel [3]. Reeds de eerste versie van het MKR bevatte naast het reglementaire gedeelte ook een lijst met ziekten en gebreken "die ongeschikt maken voor den militairen dienst", zoals Romeyn [4] stelt.

De keurend arts onderzocht de rekruut op de aanwezigheid van die ziekten en gebreken. Indien ziekten of gebreken aanwezig bleken te zijn diende de keurend arts vervolgens te bepalen of dat lijden "op hardnekkige wijze" of "in belangrijke mate" aanwezig was. Deze beide latste bevindingen leidden tot afkeuring. Na het vertrek van de Franse troepen uit ons land in 1815 werd dit MKR als keuringssysteem voor de krijgsmacht gehandhaafd.

Vanaf het prille begin van de dienstplichtkeuring speelde de mogelijke simulatie van ziekten en gebreken, om zo de dienstplicht te ontlopen, onder rekruten een rol. In de $19^{\circ}$ eeuw maakte volgens Branger [5] herkenning van simulatie onderdeel uit van de opleiding tot officier-arts. Ook in de $20^{\mathrm{e}}$ eeuw wordt de 
officier-arts door verschillende auteurs op het bestaan van simulatie geattendeerd, zoals Fouw [6], Quix, [7], Wijsman [8] en Spruyt [9].

Daarnaast ontstaat volgens Romeyn [10] al spoedig na de invoering van het MKR de tendens om actief dienende ongeschikte miliciens zo snel mogellijk aff te keuren, teneinde de sterfte binnen de Landmacht te laten dalen.

In de loop der tijden werden zowel MKR als de lijst met ziekten en gebreken periodiek aangepast. Dit had onder meer te maken met het ontstaan van meer verfijnde meetmethoden (gehoor), nieuwe endemische ziekten (tuberculose), wetenschappelijke ontwikkelingen (intrede van de psychologie) en gewijzigde taakstelling (met de exploitatie van koloniën deden tropische ziekten hun intrede).

Ter verfijning van de selectiecriteria nam de KL in 1946 het Canadese PULHEEMS-selectiesysteem over, vertaald als het ABOHZIS-systeem [11]. De letters ABOHZIS stonden voor Algemene fysieke toestand, Bovenste extremiteiten, Onderste extremiteiten, Horen, Zien, Intelligentie en Stabiliteit. Voor elk van deze deelgebieden werd een indeling in vijf classificaties gehanteerd, lopend van één tot vijf (bijvoorbeeld $\mathrm{A}_{1}, \mathrm{~B}_{2}, \mathrm{O}_{3}$ etc.). Op deze wijze werden de inmiddels 282 ziekten en gebreken uit het MKR over de zeven deelgebieden verspreid. Voor elke militair werd bij de keuring een ABOHZIS-classificatie opgesteld. Daarbij betekende een 1-classificatie dat men niet aan een in het MKR vermelde ziekte of gebrek leed, hetgeen in toenemende mate well het geval was indien men een 2-classificatie of hoger kreeg. Elke 5-classificatie leidde tot ongeschiktverklaring. Hierdoor werden de begrippen "hardnekkige wijze" en "mits in belangrijke mate" nader gedetailleerd. Verminderde belastbaarheid werd aangeduid door het hanteren van één of meer graden " 2 ", " 3 " of "4" in de ABOHZIS-classificatie. Deze verminderde belastbaarheid werd vervolgens door middel van een beperking verduidelijkt. Zo werd bij een bepaald perceptief verlies in het toonaudiogram de beperking "mag nog uitsluitend met dubbele gehoorbescherming en uitsluitend ten behoeve van het bijhouden van de schietvaardigheid schieten" opgelegd.

Oorspronkelijk was de combinatie van MKR met ABOHZIS-classificatie alleen bedoeld om dienstplichtigen te keuren. In 1959 werd deze classificatie ook voor het beroepspersoneel ingevoerd. Koster [12] beschrijft dat vanaf dat moment aan beroepspersoneel hogere eisen werden gesteld dan aan dienstplichtigen. Voor beroepspersoneel werd de minimale geschiktheidnorm de "2-classificatie"; voor dienstplichtigen werd de "3-classificatie" gebruikt naarmate clit (qua personele behoefte) het beste uitkwam.

Dit onderscheid is tot het einde toe blijven bestaan. De ABOHZIS-classificatie werd de maatstaf voor de algemene inzetbaarheid; op grond van die classificatie 
werd beroepspersoneel in verschillende klassen ingedeeld. De klassering was bepalend voor de kansen op bevordering. Vervolgens werd deze indeling ook op actief dienend beroepspersoneel toegepast. Vanaf 1960 moest iedere beroepsmilitair orn de 5 jaar op deze manier worden gekeurd. Daarmee werd het Periodiek Geneeskundig Onderzoek (PGO), zoals de KL dat tot 1996 heeft gekend, een feit: De classificatie en de bijbehorende beperkingen die uit dit PGO voortvloeiden, werden grotendeels ontleend aan het medisch dossier dat ter inzage bij die keuring werd meegegeven. Ter illustratie: de keurend arts constateerde dat de militair in kwestie jaren geleden was geopereerd aan een hernia van de rug; zocht vervolgens in het voorschrift op welke classificatie daarbij werd aanbevolen, waarna beperkingen werden opgelegd, ongeacht de status praesens van de keurling:

Het ABOHZIS-classificatie systeem functioneerde op deze wijze als een verlengstuk van de lijst van ziekten en gebreken uit het MKR. Verdere detaillering werd in 1967 bereikt met de invoering van de Ministeriële Publicatie 35-401, de "Aanwijzingen voor artsen belast met militaire keuringen". In deze regeling werd voor alle gradaties van de ziekten en gebreken een bepaalde ABOHZIS-classificatie voorgeschreven. Hierdoor was er voor de keurend arts nauwelijks meer sprake van professionele autonomie. Tegelijkertijd werd het MKR in 1967 voor de laatste maall herzien.

Op grond van het bovenstaande kunnen bij het MKR, tezamen met de lijst van ziekten en gebreken en de ABOHZIS-classificatie, de volgende kritische kanttekeningen worden geplaatst. Het keuren van dienstplichtigen betekent rekening houden met simulatie $[5,6,7,8,9]$, hetgeen de zuivere oordeelsvorming niet ten goede kan zijn gekomen. Risicowering [10] speelt vanaf het begin van de dienstplichtkeuring een rol. Ook het vanaf 1959 gemaakte onderscheid in eisen tussen beroepspersoneel (zwaarder) en dienstplichtigen (lichter) kan worden beschouwd als een vorm van risicowering [12]. Beroepsmilitairen dienden voor het vervullen van dezelfde functie in mindere mate te lijden aan bepaalde ziekten of gebreken dan dienstplichtigen. Het systeem is diagnose-gericht en niet gebaseerd op het model belasting-belastbaarheid [13]. Op grond van aandoeningen wit het verleden worden beperkingen opgelegd. Het MKR ontwikkelde zich tot 1967 naar de samenleving. Juist sindsdien zijn de ontwikkelingen in de samenleving groter geweest dan ooit tevoren. Er is derhalve sprake van een gedateerd keuringssysteem, waarin risicowering een grote rol speelt.

Van Kessel [14] beargumenteerde al in 1984 om bovengenoemde redenen dat het ABOHZIS-systeem geen relatie met de feitelijke militaire werkzaamheden vertoont. Sindsclien is de aard van de feitelijke militaire werkzaamheden sterk 
veranderd (beroepsleger, buitenland-missies), waardoor die relatie thans zeker nog ontbreekt.

Naast deze beschouwing op militaire keuringen werd vanaf de tachtiger jaren van de $20^{\circ}$ eeuw onderzoek verricht waardoor de kwaliteit van aanstellingskeuringen in bredere zin in ons land ter discussie kwam te staan.

\subsubsection{Onderzoek naar de kwaliteit van aanstellingskeuringen}

\section{Onderzoek uit Nederland}

Vanaf 1989 onderzocht De Kort, samen met wisselende andere onderzoekers zoals Lourijsen, Post-Uiterweer en Van Dijk, de omvang, kosten en kwaliteit van aanstellingskeuringen in Nederland $[2,15,16,17,18,19]$. Bij deze onderzoeken werden de betrouwbarheid, validliteit en voorspellende waarde gehanteerd als graadmeters voor de kwaliteit van de medische aanstellingskeuring als meetinstrument. Omdat de laatste twee graadmeters in de praktijk moeilijk te onderzoeken zijn voor keuringen (zie paragraaf 1.5), werd hiervoor in de plaats een literatuuronderzoek verricht [15]. Op basis van de gevonden literatuur bleken nauwelijks argumenten te vinden voor de onderbouwing van de veronderstelling dat door aanstellingskeuringen gezondheidsschade en ziekteverzuim kan worden voorkomen. Weging van voor- en nadelen bij het opzetten van het complete instrument aanstellingskeuring vindt niet plats, evenmin als bij de verschillende afzonderlijke elementen uit de keuring. Het eindoordeel bleek tot stand te komen op basis van weging van de verschillende keuringsonderdelen, waarbij zowel de relevantie als de voorspellende waarde van de gebruikte onderzoeken ontbraken.

Voor het beoordelen van de betrouwbarheid vond in diezelfde periode cen vagenlijst-onderzoek onder 2350 bedrijven en 1750 artsen plaats. Op deze wijze wilde men inzicht $k r i j g e n$ in de hoeveelheid en het doel van de keuringen [16]. Uit dat vragenlijstonderzoek komt een grote pluriformiteit naar doel, werkwijze en maatstaven aan de orde bij telkens een laag percentage afgekeurden.

Daarnaast werd de mate van overeenstemming onderzocht door middel van het reproduceerbaarheidonderzoek [2], waarvan al in paragraf 1.2 gewag werd gemaakt. Bij dit onderzoek werden de dossiers van zowel 90 geschikt verklaarde als 90 ongeschikt verklaarde kandidaten aan een panel van vijf artsen voorgelegd. De gevonden overeenstemming was laag. Bovendien bleek een meer gede-tailleerde instructie (die voor sommige functies was beschreven) slechts geringe invloed op de mate van overeenstemming te hebben. 
Bovenstaande onderzoeken maakten in 1993 onderdeel uit van het proefschrift van De Kort [17]. Hij woegde hieraan enige publicaties toe. Eén ervan betreft een studie naar het aantal afwijzingen - plus de vermelde oorzaken daarvoor bij de populatie van de toenmalige Rijksbedrijfsgezondheids- en Bedrijtsveiligheidsdienst (RBB) [18]. Op grond wan de resultaten van deze studie concludeerde hij dat het percentage afkeuringen vrijwell altijd erg laag ligt en dat derhalve deze keuringen weinig toevoegen aan het wervingsproces. Voor de kleine groep die wordt afgekeurd ontbreekt bovendien een reproduceerbaar, gestandaardiseerd en valide onderzoek. Daarnaast vermeldde hij in het proefschrift een studie waarin 235 individuen met vroege uitval op het werk werden onderzocht op de relatie tussen bij de aanstellingskeuring gevonden medische bijzonderheden en de oorzaak van de uitval op het werk [16]. Met name omdat in de meerderheid van deze gevallen er helemaal geen medische bijzonderheden bij de aanstellingskeuring zijn genoteerd, concludeerde De Kort dat deze keuring slechts weinig bijdraagt aan het voorkomen van uitval op het werk. Tevens concludeerde hij dat het effect van een aanstellingskeuring op het terugdringen van arbeidsgebonden aandoeningen en vroeg optredende arbeidsongeschiktheid gering is.

In 1997 publiceerde De Kort [19] nog een artikel waarin hij het begrip aanstellingskeuring theoretisch en rekenkundig benadert. Hij definieert het preventieve effect van de aanstellingskeuring als: de benodigde inspanning - het aantal handelingen - benodigd om één uitvaller door beroepsziekte of arbeidsongeschiktheid te voorkomen. Achtereenvolgens berekent hij de prognostische positieve voorspellende waarde (PPV), het attributieve risico en het aantal af te wijzen kandidaten om één risicodrager uit te sluiten. Hieruit blijkt dat veel keuringen moeten worden verricht, altijd met een aantal fout-positieven, om cen enkele risicodrager te weren.

Net als in zijn proefschrift voegt De Kort daaraan de nuancering toe dat het gebruik van testmethoden met een lage voorspellende waarde aanvaardbaar kan zijn als het te vermijden risico groot wordt geacht. Als voorbeeld wijst hij naar de keuring van luchtvarenden, waarbij als consequentie veel kandidaten worden afgewezen.

Vermeldenswardig is ook het proefschrift van Reulings [20]. Zij onderzocht in een serie artikelen $[21,22,23,24,25]$ in hoeverre medisch disfunctioneren bij actief dienenden te voorspellen viel en in welke mate militaire keuringen reproduceerbaar waren. Zij verschafte eerst uitleg over het complexe keuringstraject dat voor dienstplichtigen werd gehanteerd [21]. Vervolgens verrichtte zij retrospectief cohortonderzoek onder 8714 dienstplichtigen naar het vermogen van de dienstplichtkeuring ( $b i j$ 16- en 17-jarigen) als selectie-instrument [22]. 
Statistisch bleek 6\% na opkomst medisch te disfunctioneren, hoofdzakelijk ofwel op grond van aandoeningen aan rug en onderste extremiteiten ofwel op grond van onvoldoende psychische stabiliteit. In alle drie deze situacies bleek een hoge (minder geschikt aanduidende) ABOHZIS-classificatie tijdens de dienstplichtkeuring een goede voorspeller te zijn. In een derde onderzoek [23] werden de afkeuringsgronden en afkeuringspercentages van de destijds verschillende regionale keuringsraden voor de dienstplichtkeuring onderling vergeleken. De aanname daarbij was dat er geen regionale gezondheidsverschillen bestonden en de gevonden percentages tussen de verschillende keuringsraden vergelijkbaar zouden moeten zijn. Dit bleek niet het geval te zijn, hetgeen voor een deel zou worden verklaard door procedureverschillen tussen die keuringsraden, en voor een ander deel zou berusten op grond van verschillen tussen individuele artsen. Hierna werd de reproduceerbaarheid van dienstplichtkeuringen onderzocht met behulp wan geanonimiseerde casussen door artsen van verschillende keuringsraden [24]. De gevonden overeenstemming was daarbij laag. Tenslotte werd ditzelfde onderzoek herhaald, maar nu met dossiers van beroepsmilitairen afkomstig uit het periodiek geneeskundig onderzoek $[25$, zie hoofdstuk. 2].

Reulings wees vervolgens op een aantal nadelen van het gebruik van de ABOHZIS-classificatie, zoals het risicowerende karakter ervan en het ontbreken van eisen wartegen de op grond van die classificatie opgelegde beperkingen kunnen worden afgezet.

Omdat het overgrote gedeelte van de dienstplichtigen terecht bleek goedgekeurd, constateerde zij dat de negatieve voorspellende waarde van de dienstplichtkeuring hoog ligt.

Ook buiten artikelen over de kwaliteit van keuringen zijn in de literatuur risicofactoren gevonden die voor de kwaliteit van keuren relevant kunnen zijn. Door Van Deursen, Otten, Smulders, Houtman en Bongers is in de periode van 1997 tot 1999 onderzoek verriclat naar de relatie tussen gezondheid en verzuim $[26,27,28]$. Hieruit bleek dat risicofactoren zoals de gezondheidstoestand, waarvan vooraf werd angenomen dat zij belangrijk waren, feitelijk slechte voorspellers waren, terwijl andere minder verwachte factoren zoals de privé-situatie of verschillen op grond van leeftijd en geslacht nu juist wel relevant bleken te zijn.

\section{Internationad}

Ook internationaal is gezocht naar informatie over de kwaliteit van (anstel lings-) keuringen. In de eerste plaats werden wereldwijd via de militaire attachés gerichte vragen gesteld omtrent de specifieke keuringssituatie bij verschillende krijgsmachten in het buitenland. Naar aanleiding hiervan werd releurstellend 
weinig materiad ontvangen. In total werden slechts 3 reacties ontvangen: uit Japan, Frankrijk en India. Het betreffende materiaal gaf alleen inzicht in de gebruikte testen en apparatuur (vergelijkbaar met die van de KL), zoals voor visus en gehoor, samenhangend met een medisch onderzoek. Standaarden of normen werden, ondanks het verzoek daartoe, niet specifiek vermeld.

Daarnast is ook in de internationale literatuur gezocht ${ }^{1}$. Hierbij werden geen artikelen gevonden die vergelijkbaar waren met het onderzoek uit eigen land. De gevonden artikelen behandelen onderdelen van keuring of selectie en zijn hoofdzakelijk gericht op het meten of vergroten van fysieke prestaties. Veel literatuur bleek uit militaire kring afkomstig te zijn. In die literatuur is ook aandacht voor onderwerpen zoals trainingsopbouw, blessurepreventie en onderzoek naar oorzaken van vroege uitval na indiensttreding.

Ondanks de hierboven geschetste tekortkomingen zitten er toch onderwerpen tussen die relevant genoeg zijn om te vermelden. Er worden belangrijke risicofactoren voor vroegtijdige uitval beschreven. Als onderdeel daarvan wordt het ontstaan en de achtergrond van de fysieke selectie, die ook bij de KL rondom de medische aanstellingskeuring een rol speelt, geschetst. Uiteindelijk kan ook uit de internationale literatuur lering woor verder onderzoek worden getrokken.

Eén van de bij een keuring gebruikelijke instrumenten is de anamnese. Bij veel keuringen wordt een vragenlijst als (onderdeel van de) anamnese gehanteerd. Jacobs [29] onderzocht gelijktijdig de reproduceerbaarheid en validiteit ("gouden standaard": tredmolentest, vitale capaciteit, percentage lichaamsvet) van 10 in de VS gebruikelijke vragenlijsten naar lichamelijke inspanning onder 78 mannen en vrouwen van 20 tot 59 jaar. De betrouwbaarheid gedurende de eerste maand bleek in alle gevallen hoog te zijn, nadien daalde de betrouwbaarheid. De correlatie met de gouden standaard was in alle gevallen laag. Hij adviseerde voorts in zulke vragenlijsten ook navrag te doen naar inspanningen gedurende vrijetijdsbesteding en huishoudelijk werk.

Weller [30] onderzocht de test-hertest betrouwbaarheid van de Canada Fitness Survey questionnaire met de Canadian Aerobic Fitness Test als "gouden standaard" bij 127 onderzoekspersonen ( 64 mannen en 63 vrouwen) tussen de 15 en 80 jaar. Voor de meeste activiteitsvariabelen lag de correlatie bij mannen hoger $\left(\mathrm{r}_{1}=0,28-0,60\right)$ dan bij vrouwen $\left(r_{1}=0.38-0.65\right)$. Zij concludeerde dat

L Databases: Medline, DIRLine, HeathSTAR, HISTLINE, OLDMEDLINE, POPLINE, SDLINE, OSH-ROM, National Library of Medicine. Zoeltermen: validity/predictive value, health cximintion/(pre-employment medcial) assessment occupational (health), physical/pshycological selection, attrition. 
deze vragenlijst slechts matig betrouwbaar is voor het meten van de meeste lichamelijke activiteiten.

Er is tevens veel internationaal onderzoek verricht naar de effecten van fysieke training. Zowel Vogel [31] als Stacey [32] onderzochten het trainingseffect op rekruten (Britse, respectievelijk Nieuw-Zeelandse) door de $\mathrm{VO}_{2}$ max met fietsergometrie te (her-) meten bij opkomst en aan het eind van de opleiding. Beiden vonden een stijging van de $\mathrm{VO}_{2}$ max en een daling van het percentage lichaamsvet onder gelijkblijvend lichaamsgewicht en beschouwden dit als een bewijs voor de effectiviteit van het trainingsprogramma.

Voorts is veel onderzoek verricht naar de risicofactoren voor het oplopen van blessures, onder meer door Jones [33, 34], Jordaan [35], Almeida [36] en Pope [37]. De onderzoeksopzet is telkens prospectief van aard: het meten van prestaties bij rekruten direct na opkomst en nogmaals aan het einde van de militaire opleiding, tezamen met het afnemen van een vragenlijst. Alom worden door deze auteurs de volgende risicofactoren geduid: gebrekkige basisconditie, eerdere blessures, te intensieve training(-sprogramma's). Vrouwelijke rekruten zijn meer blessuregevoelig dan mannelijke. De belangrijkste aanbevelingen zijn om maatwerk trainingsprogramma's te hanteren, voldoende aandacht te schenken aan blessurepreventie, maar ook om selectie te plegen op grond van een minimaal vereiste basisconditie.

In de hierboven vermelde studies is de relatie tussen de keuringsbevindingen (aan het bewegingsapparaat) en eventuele uitvalsoorzaken niet onderzocht. Ross [38] onderzocht die relatie wel. Hij verzamelde in een retrospectieve case-control studie (bij Australlische rekruten) elke anatomische afwijking aan de onderste extremiteiten uit de keuringsdossiers, niet zijnde van de huid, als variabele. Deze anatomische afwijkingen bleken risicofactoren te vormen. Bij onderzoek naar de fysieke screening op voetafwijkingen bij Australische rekruten concludeerde Rudzki [39] echter een slechte sensitiviteit en specificiteit, evenals een slechte voorspellende waarde, van deze onderzoeksmethode ten aanzien van optredende blessures.

Stevenson [40] verrichtte onderzoek naar de minimaal vereiste basisconditie voor het Canadese leger. Op grond van de gevonden resultaten adviseerde hij een ondergrens voor geschiktheid bij de fysieke test voor alle rekruten tezamen op de vijfde percentiel. Dit betekent echter in de praktijk dat vrouwelijke kandidaten aan hogere eisen moeten voldoen dan mannelijke.

Door een minimum aan conditie te eisen (conditietest) bij aanname wordt het oplopen van blessures teruggedrongen. Maar zo'n fysieke test voorspelt niet of een rekruut met succes de militaire opleiding zal afsluiten. Bij onderzoek van Chin [41] bleek geen statistisch significant verschil te zijn tussen de gemiddelde 
$\mathrm{VO}_{2}$ max van de geslaagden en de drop-outs tijden de opleiding van Amerikaanse luchtmachtrekruten, evenmin als bij een onderlinge vergelijking van het resultaat van de 2 -mijlsloop.

Williams [42] evalueerde de doeltreffendheid van het Britse trainingsprogramma voor rekruten. Hij onderzocht fitness, kracht en het vermogen om met militair materieel om te gaan. Het programma blijkt vooral de fitness te verhogen, maar omgang met het militaire materieel en de kracht worden weinig beînvloed door het programma. Het programma faalt derhalve in het opzicht om rekruten op hun militaire taak voor te bereiden.

Rayson [43] vermeldde in een serie artikelen de totstandkoming van zogenaamde takkcriterium tests (eenmalig tillen, dragen, herhaald tillen en marsen met bepakking) on tot een betere fysieke indeling van Brits militair personeel te komen. De beschreven werkwijze vertoont sterke overeenkomst net de wijze waarop de KL haar personeel indeelt.

Er bestaan nog meer risicofactoren voor het niet behalen wan de militaire opleiding dan louter fysieke. In 1990 wist McCraw [44] rekruten, die op grond van aanpassings en motivatieproblemen de militaire opleiding niet zouden afronden, met behulp van een zelf in te vullen persoonlijkheidstest te onderscheiden van de overige rekruten. Carbone [45] analyseerde 59 variabelen op het gebied van motivatie, biografie en psychologische test-uitkomsten onder 632 Amerikaanse Luchtmachtrekruten, waarvan de ene helft de opleiding afrondde en de andere helft niet. Hij concludeerde dat met behulp van een klein aantal van die variabelen tot op $70 \%$ nauwkeurig kan worden voorspeld of iemand de opleiding zal halen. Optimisme en motivatie ("Ik ga die opleiding halen", "Ik vind her leuk om nieuwe dingen te leren"), de hoeveelheid spreekuurcontacten met de behandelend militair arts en lichamelijk misbruik in de anamnese hebben in dat model de grootste bijdrage. Ook het onderzoek van Crawford [46] toont het bestaan van misbruik in de anamnese aan als risico-factor voor uitval tijdens de militaire opleiding in de VS.

\section{Interpretatie vaw de literatum poor verder onderzoek}

De teneur in de onderzoeken van De Kort is dat de aanstellingskeuring ontoereikend is voor het gestelde doel. Wel wordt door hem erkend [17, 19] dat de noodzaak voor een keuring meer gerechtvaardigd zou kunnen zijn indien het te vermijden risico groot wordt geacht.

Uit de artikelen van De Kort komen een aantal argumenten naar voren die nut en noodzaak van aanstellingskeuringen ter discussie stellen. Het aantal afkeuringen is vaak لaag [16, 18]. Hij signaleert voorts een ontbrekende relatie tussen medische bijzonderheden en uitval op het werk [17]. Daarnaast rekent hij het gebrek an reproduceerbaarheid voor [19]. Hij toont aan hoeveel onnodig afge- 
keurden, die theoretisch wel over de juiste kwaliteiten zouden beschikken, alsnog optreden[19].

De enige kanttekening die men bij zijn onderzoek zou kunnen plaatsen is dat hij zich in diverse artikelen $[15,16,18]$ hoofdzakelijk richt op het beperkte effect van een aanstellingskeuring op het terugdringen van arbeidsgebonden aandoeningen en vroeg optredende arbeidsongeschiktheid. Klein Hesselink [47] vermeldt vele factoren (onderverdeeld in persoonsgebonden, bedrijfsgebonden en maatschappelijke oorzaken) die uitval door ziekteverzuim kunnen beinvloeden. Deze factoren kunnen onderzoek naar het effect wan de anstellingskeuring en op uitval door ziekmelding of arbeidsongeschiktheid beinvloeden. Bovendien behoeft het in mindere mate voldoen aan de gestelde (keurings-)eisen niet altijd tot uitval op grond van beroepsziekten of arbeidsongeschiktheid te leiden. Er zijn ook andere uitingen van het minder aan de gestelde eisen voldoen denkbaar, zoals het vertonen van een lagere productienorm, het vertonen van herhaald kortdurend verzuim of alleen maar het uiten van een lagere arbeidssatisfactie tijdens het inloopspreekuur van de bedrijfsarts.

De conclusies van het onderzoek van Reulings [20] sluiten in meerdere opzichten aan bij die van De Kort. Ook zij vond een laag percentage afgekeurden [22], en uit haar onderzoeken bleek evenzeer de reproduceerbaarheid van de betreffende keuring gering te zijn [23, 24, 25]. Ook bij haar onderzoek vallen echter enige kanttekeningen te maken. Haar onderzoek was hoofdzakelijk gericht op dienstplichtigen, waarvan sinds 1996 geen sprake meer is. Van dienstplichtigen is in paragraaf 1.3.1 een aantal factoren vermeld, die van invloed kunnen zijn op de uitslag van de keuring, zoals simulatie $[5,6,7,8,9]$ en risicowering [10]. Deze factoren kunnen het aantal afkeuringen onnodig hebben verhoogd en de reproduceerbarheid negatief hebben beinvloed. $Z_{i j}$ constateerde voorts dat een hoge ABOHZIS-classificatie - als maatstaf voor een serieus afwijkende keuringsbevinding - een goede voorspeller zou zijn voor uitval als dienstplichtige [22]. Tegelijkertijd constateerde zij echter ook dat de reproduceerbaarheid warmee die classificaties worden gehanteerd onder de vereiste norm blijft $[24,25]$. Dat laatste betekent dat de validiteit van het gehanteerde keuringssysteem in elk geval volgens Bouter en Van Dongen[1] onvoldoende moet zijn geweest.

In de internationale literatuur komen de volgende feiten an bod. Vragenlijsten naar de mogelijkheden voor fysieke inspanning blijken alleen op korte termijn betrouwbaar [29]. Op grond van fysieke risicofactoren voor uitval tijdens de militaire opleiding $[33,34,35,36]$ (geslacht, gebrekkige basisconditie, eerdere blessures) wordt een aantal preventieve maatregelen geadviseerd, waaronder de 
vaststelling van een minimal vereiste basisconditie bij anname $[40,43]$. Naast oude of nieuwe blessures spelen motivatie, artsenbezoek en misbruik in de anamnese een rol bij uitval.

Opmerkelijk genoeg kan de voorspellende waarde van keuringsbevindingen an het bewegingsapparat in relatie tot uitval niet worden aangetoond in zowel een onderzoek van De Kort [17] als dat van Rudzki [39].

Ook bij de internationale literatuur moeten kanttekeningen worden geplaatst. Een eerste kanttekening is dat al het militaire onderzoek niet verder reikt dan de korte opleidingsfase. Tangere termijn effecten zijn niet onderzocht. Een tweede kanttekening is dat de omstandigheden waaronder en de populatie waarop onderzoek is verricht, niet per definitie vergelijkbaar zijn met de situatie in eigen land. Ter illustratie hiervan wordt een vergelijking getrokken tussen Amerikaanse luchtmachtrekruten onderzocht door Talcott [48] en KL-militairen over 1999, dit latatste gebaseerd op interne onderzoeksgegevens, naar aard en hoeveetheid uitvallers tijdens de militaire opleiding. Hieruit blijkt dat zowel de hoeveelheid uitvalliers alls de oorzaken voor die uitval onderling volstrekt onvergelijkbaar zijn. In de VS valt $6,2 \%$ van de rekruten uit tegenover $25,6 \%$ bij de KL. De voornaanste oorzaken voor de uitval in de VS zijn medisch, psychisch en disciplinair, terwijl dit in de KL voornamelijk bedrijfsgebonden oorzaken, de thuisomstandigheden en heimwee zijn. Ter verklaring kan aan meerdere mogelijke oorzaken worden gedacht: een verschil in selectie of opleiding tussen beide organisaties, een verschil in motivatie en perceptie tussen de rekruten, verschillen tussen beide samenlevingen of combinaties van deze factoren. Met de interpretatie van internationale onderzoeksgegevens naar de situatie in eigen land moet in elk geval terughoudendheid worden betracht.

Op grond van het bovenstaande kunnen de volgende notities voor gebruik bij verder onderzoek worden gemaakt:

- Om het gevaar voor derden te verkleinen kan een organisatie gerechtvaardigde redenen hebben om scherpe keuringscriteriate hanteren.

- Het hanteren van een minimaal vereiste basisconditie moet in theorie een verlagend effect hebben op witval door nieuw optredende blessures.

- Behoudens blessures in de anamnese is er geen duidelijk verband aangetoond tussen medische bijzonderheden en uitval na tewerkstelling; dat verband is wel (zij het onder buitenlandse militairen) vastgesteld voor de mate warin men zelf een taak (bijvoorbeeld opleiding) meent aan te kunnen, eventueel misbruik als kind en de hoeveelheid artsenbezoek.

- Telkens is alleen de relatie tussen keuring en uitval onderzocht. Het in mindere mate voldoen aan de gestelde (keurings-)eisen behoeft niet altijd te leiden tot uitval op grond wan beroepsziekten of arbeidsongeschiktheid. Er 
zijn nog andere uitingen van het minder aan de gestelde eisen voldoen denkbaar dan alleen uitval door ziekte.

- In geen enkel Nederlands onderzoek is de beleving of motivatie van de betrokken werknemers meegenomen. In het algemeen wordt volstaan met het keuringsdossier en de verzuimgegevens of andere data. Broersen, Weel en Van Dijk [49] stellen dat de beleving van gezondheidsbelastende factoren mede bepaalt hoe het effect ervan op de werknemer zal zijn. Zich gezond of ziek voelen heeft niet alleen te maken met de objectieve gezondheidsrisico's, maar ook met de wijze watrop de werknemer die risico's zelf ervart. De persoonlijke beleving kan mede de onderzoeksuitkomsten (ziekmelding, uitval) beïnloeden. Het gebruik van bijvoorbeeld een periodieke vragenlijst. zou op grond hiervan een toegevoegde waarde kunnen hebben bij verder onderzoek.

- Als in zo'n vragenlijst bovendien ook nog de te stellen eisen zouden worden opgenomen, zou op die manier van de werknemer zelf kunnen worden vernomen of deze zichzelf daartoe in staat acht.

- Als naast motivatie ook de mate van artsenbezoek een rol bij uitval speelt, is het zinvol om bij verder onderzoek ook daaraan aandacht te besteden.

\subsubsection{De Wet op de Medische Keuringen (WMK) en de praktische uitvoering ervan}

Het onderzoek van De Kort, Lourijsen, Post-Uiterweer en Van Dijk [2, 15, 16 , $17,18,19]$ was één van de factoren die een rol speelden bij de totstandkoming van nieuwe wetgeving op het gebied van (aanstellings-) keuringen in Nederland: de Wet op de Medische Keuringen (WMK, 1998). Centraal in deze wet staat dat er een specifiek doel moet bestaan voor de uitvoering van een anstellingskeuring: het noodzakelijkheidcriterium (Artikel 4). Aanstellingskeuringen mogen alleen plaatsvinden als er bijzondere eisen aan de medische geschiktheid moeten worden gesteld, op basis van risico's in de betreffende functie. Bovendien moeten keuringen worden beperkt naar hun aard, inhoud en omvang tot het doel waarvoor zij worden verricht (Artikel 2 lid 1). Tevens mogen bij een keuring geen vragen worden gesteld en geen medische onderzocken worden verricht die een onevenredige inbreuk betekenen op de persoonlijke levenssfeer van de keurling (Artikel 3 lid 1).

Op deze wetgeving werd een uitzondering gemaakt middels de Wijziging van de Wet op de Medische Keuringen (1998). Die uitzondering geldt de specifieke situatie voor militair personeel en wordt in de Memorie van Toelichting van deze wet nader verklaard. Ten aanzien van het functiegericht keuren, zoals bedoeld in Artikel 4 lid 1 van de Wet op de Medische Keuringen, wordt opgemerkt dat de militaire ambtenaar niet is aangesteld in cen functie, maar als militair. 
Deze militair dient alle in het belang van de takkuitoefening van de krijgsmacht opgedragen werkzaamheden en diensten te kunnen verrichten. Daarbij kan de militair overal ter wereld onder allerlei omstandigheden worden ingezet. Zowel dege ruim geformuleerde ("alle") taakstelling als de uiteenlopende mogelijke arbeidsomstandigheden ("overal ter wereld onder allerlei omstandigheden") maken dat aan de militair zware fysieke en geestelijke eisen moeten worden gesteld. On nu de risico's bij die taakuitoefening voor de militair en voor derden zo gering mogelijk te houden worden aan elke militair (onder meer medische) eisen gesteld die betrekking hebben op diens totale operationele inzetbaarheid.

In feite stelt de wetgever hiermee dat het scala van zich mogelijk voordoende taken en arbeidsomstandigheden voor een militair zo groot is, dat bij de aanstelling met vele uiteenlopende eisen rekening moet worden gehouden.

Naast het stellen van eisen voor de uitvoering van een keuring was in de Wet op de Medische Keuringen ook de bepaling opgenomen dat door de wetgever nadere regels zouden worden gesteld inzake de te volgen procedure voor bezwaar en beklag, indien daarover door de sociale partners geen consensus zou worden bereikt. Het uitblijven van deze consensus leidde in 2001 vervolgens tot nadere regelgeving, vastgelegd in de Staatsbladen 597 en 598. Op grond hiervan is een onafhankelijke klachtencommissie ingesteld waar keurlingen hun beklag kunnen doen over de aard, inhoud en procesgang van en bij de keuring (Staatsblad 598). Daarnaast worden de in de Wet op de Medische Keuringen vermelde toetsingscriteria voor het verrichten van een aanstellingskeuring scherper omschreven (Staatsblad 597). Keuringen mogen alleen worden verricht indien aan de betreffende functie bijzondere eisen op het punt van medische geschikt-heid worden gesteld en dan alleen nog indien de (te benoemen) risico's niet met gangbare matregelen kunnen worden gereduceerd. De keuringvrager moet de te stellen eisen schriftelijk vastleggen en inzake de rechtmatigheid ervan advies vragen bij een Arbo-dienst.

Voor het verder operationaliseren van aanstellingskeuringen door Arbo-diensten is door Hulshof [50] in opdracht van de Branche Organisatie Arbo-diensten de Algemene Richtlijn Aanstellingskeuringen (ARA) ontwikkeld. De richtlijn bevat een stappenplan, alsmede een overzicht van functie-eisen met bijbehorende gezondheidscriteria en onderzoeksmethoden.

Het stappenplan bevat achtereenvolgens de volgende vijf stappen:

- Het informeren van de klant.

- Het opstellen van functie-eisen. Hierbij wordt een model verstrekt aan de hand warvan kan worden bepaald voor welke functie-eisen een bijzonder beroep op de medische geschiktheid wordt gedaan. De ARA bevat een 
beoordelingsformulier waarmee an de hand van 18 veel voorkomende functie-eisen kan worden nagegaan of er sprake is van bijzondere eisen ten aanzien van de medische geschiktheid voor de functie. Dit formulier geeft een globale klassering in termen varièrend van afwezig (klasse 1) tot zeer zwaar (klasse 5). Essentieel is dat het om risicofactoren moet gaan die de werkgever niet redelijkerwijs met preventieve of andere matregelen kan terugdringen.

- Het maken van de keuze of er al dan niet een aanstellingskeuring moet plaatsvinden.

- Het vaststellen van de inhoud van de aanstellingskeuring.

- Het uitvoeren van de aanstellingskeuring.

Bij het opstellen van de eisen en het bepalen van het al dan niet uitvoeren van een aanstellingskeuring moeten volgens dit plan de volgende vragen worden beantwoord:

- Zijn er functie-eisen met een ongewoon hoge belasting?

- Is die belasting niet met gangbare maatregelen te reduceren?

- Is er een kans op gezondheidsschade?

- Zijn de eisen te vertalen in gezondheidscriteria?

- Is medisch onderzoek mogelijk?

- Zijn er normen?

- Vormt de gehanteerde methode een valide indicator?

- Staat het te verrichten onderzoek in verhouding tot het doel van de keuring (het proportionaliteitscriterium)?

- Bestaat er geen minder belastende of ingrijpende onderzoeksmethode (subsidiariteitcriterium)?

- Leidt de onderzoeksmethode niet tot ongerechtvaardigde differentiatic en/of discriminatie van groepen in de samenleving?

- Is het te verrichten onderzoek relevant voor het doel van de keuring?

- Is keuren toegestaan?

- Zijn de eisen door een bedrijfsarts vastgesteld?

De ARA is geen juridisch binclende richtlijn; men mag er beargumenteerd van afwijken. Daaraan moet echter worden toegevoegd dat in de Nota van Toelichting van de Staatsbladen 597 en 598 wordt vermeld dat de ARA een eerste poging tot ordening in de praktijk is en door de klachtencommissie kan worden gehanteerd als toetsingskader voor wat in de beroepsgroep gebruikelijk is. Dit maakt de ARA alleminst tot een vrijblijvend advies. 
De tot nu toe beschreven niet-systematische zowel als de systematische waarne-mingen vormden aanleiding voor de vraag of het bestaande keuringssysteem niet aan vervanging toe was.

\subsection{Een nieuw keuringssysteem en de relatie ervan met wet- en regelgeving}

\subsubsection{De ontwikkeling van een nieuw keuringssysteem}

De Wet op de Medische Keuringen staat uitvoering van aanstellingskeuringen alleen toe indien aan de medische geschiktheid bijzondere eisen moeten worden gesteld. Weliswaar wordt in de Wijziging van de Wet op de Medische Keuringen aangegeven dat bij het aanstellen van militair ambtenaren met vele mogelijke eisen rekening moet worden gehouden, maar dat laat onverlet dat er eisen moeten worden gesteld.

$\mathrm{Bij}$ het tot dan toe in gebruik zijnde diagnosegerichte keuringssysteem bij de $\mathrm{KL}$ was daarvan geen sprake. Afwijzing of ontslag vonden plaats op grond van een zekere mate van ziekte of gebrek, eisen waaraan de militair diende te voldoen waren niet geformuleerd. Er was geen sprake van een relatie tussen belasting en belastbaarheid [13]. Mede omdat deze situatie voorts in de praktijk tot rechtspositionele en juridische problemen leidde (een ontslagaanvrage omdat een militair op grond van ziekten en gebreken niet operationeel inzetbaar werd geacht, werd afgewezen door de ambtenarenrechter), gaf de KL-leiding in 1997 opdracht om functie-eisen voor militairen te laten ontwikkelen en deze op medisch gebied te laten operationaliseren [51].

Gelet op de bijzondere positie van de militair, zoals in de vorige paragraaf weergegeven, werd besloten om voor alle militairen in beginsel dezelfde algemene en brede functie-eisen te definiëren. In de loop van 1997 werden de eisen, minimaal te stellen aan $\mathrm{KL}$-militairen, geformuleerd op grond van de concrete activiteiten van militairen. Die eisen strekken zich uit over de volle breedte van het functioneren als militair ambtenaar, inclusief de mogelijkheid tot wereldwijde operationele inzet. Deze eisen werden de Militaire basiseisen KL genoemd.

Om deze functio-eisen te operationaliseren is gebruik gemaakt van twee bronnen. In de eerste plaats werd gebruik gemaakt van het belastbaarheidpatroon van het Functie Informatie Systeem (FIS) ${ }^{2}$. Dit FIS omvatte 28 beoorde-

2 Het belastbaarheidspatroon wan het $\mathbb{F}[S$ is een beoordelingssysteem warbij in de vorige eeuw voor de Nederlandse marktsector de belasting van bestaande arbeid in katr is gebracht door middel wan 28 beoordelingspunten. Bij veel van deze beoordelingspunten kan gedifferentieerd worden tussen verschillende prestatieniveaus. 
lingspunten op fysiek en mental terrein tan handelingen en gemoedstoestanden, die alle relevant bleken (omdat zij zich veelwuldig voordoen) voor het operationaliseren van de werkgeverseisen. Maar hiermee werd het complete scala aan militaire werkgeverseisen niet afgedekt. Zo wordt an het kunnen schieten met een vuurwapen in het FIS geen aandacht geschonken, evenmin als de handeling graven erin voorkomt. Daarom wend daarnaast gebruik gemaakt van beoordelingspunten die specifieke militaire vaardigheden betreffen, op dezelfde wijze als het FIS ontwikkeld door sportartsen en bewegingswetenschappers van de Arbo-dienst KL. Dit leidde in december 1997 tot het opstellen van een lijst met 43 beoordelingspunten. Elk beoordelingspunt werd voorzien van een grenswaarde: de Basismedische Eis $\mathrm{KL}$ (BMEKL). Ter illustratie vermeldt beoordelingspunt 15 (dragen) als basiseis "het kunnen dragen van $25 \mathrm{~kg}$ gedurende 2 uur per werkdag", en heeft beoordelingspunt 32 (springen) als basiseis "het van en/of over 1 in kunnen springen".

Anders dan bij de WAO-keuring waarvoor het FIS tot december 2001 werd gebruikt, worden de BMEKL gehanteerd op een dichotome wijze: de gekeurde wordt beschouwd als zijnde wel of niet beperkt (geschikt of ongeschikt) voor het vervullen van de basale militaire functie - het gat om de minimale geschiktheid, met inbegrip van operationele inzetbaarheid. Een ovarzicht van de 43 beoordelingspunten en basismedische eisen wordt in tabel 1 weergegeven.

Centraal bij het hanteren wan de BMEKL stat de vraag of er bij de keuring sprake is van medische bijzonderheden. Onder een medische bijzonderheid wordt elke afwijkende medische bevinding verstaan, die in het kader van de keuring wordt geconstateerd.

Voor het onderzoek naar deze medische bijzonderheden zijn tevens keuringsprotocollen ontwikkeld, die een brug slaan tussen de keuringsgegevens en de consequenties die daaraan worden verbonden in het kader van de basismedische eisen [51]. Bij het ontwikkelen van deze keuringsprotocollen is ervoor gekozen om het onderzoek naar de meest voorkomende medische bijzonderheden bij militaire keuringen te protocolleren. Aldus werd één algemeen onderzoeksprotocol ontwikkeld, tezamen met 25 specifieke, op bepaalde lichaamsdelen, respectievelijk op specifieke aandachtsgebieden (zoals het gebruik van geneesmiddelen) en op tracti (zoals digestivus, urogenitalis) gerichte protocollen. Bij elk van deze protocollen is aangegeven wat standaard zou mocten worden gevraagd, onderzocht, gemeten en op welke wijze hieraan consequenties moeten worden verbonden.

Bij de keuring wordt standaard het algemene protocol (nummer 1) gehanteerd. In geval op het terrein van één van de specifieke keuringsprotocollen een medi- 
Tabel 1. Een overzicht van de beoordelingspanten en Basismadische Eisen

\begin{tabular}{|c|c|c|}
\hline W & Beoord dingspunt & Basimedische Eis \\
\hline 1 & Zillten & Znten gedurende wojwel de gehele werkdag 2 uur aneengesloten \\
\hline 2 & Stwan & Stangedurende vrijwel de gehele werldag 2 uur andengesloten \\
\hline 3 & Loper & Lopen gedunende wrijwel de gehele werkdag 1 wur and angesloten \\
\hline 萠 & Trapperislopen & Trappenlopen 9 seer per tur 25 treden \\
\hline 5 & Klommery en ktateren & Klimmen of klauteren 8 keer per uur 5 meter \\
\hline 6 & Knielen, kriupen on liurken & $\begin{array}{l}\text { Kniwen, kruipen; hurken gednemde } 4 \text { mur per werkdag en half } \\
\text { uur aneengesloten }\end{array}$ \\
\hline
\end{tabular}

7 Gebogen werken

8 Kortoyclisch buigen en tordercin

9 Gebruilk van de nek

10 Reiken

11 Dowentrands worken

12. Hand-en vingergetiruik

13. Tillen

14. Duwen en trekken

15. Dragen

16 Luchtwerplatsing

17 Stor, rook, gas en damp

18 Konde

19 Mitte

20 Tenperatunuwisse hingen

21 Luchwochtighwd.

22 Droge hicht

23 Wuidcontinct

24 Vibratiobelasting

$25 \mathrm{H}$ Zintuigen-gehoor

$25 Z$ Zintoigen-zich

$25 \mathrm{~K}$ Zintuigenkleuronderscheiden

26 Beschermende middelen

27 Persomilike risico.

28 Pychische belasting

29 Algemene condirie
Gobogen waken gedurende vrijwel de gehele werkdag 1 kwartier wamengesloten

Buigen of torderen 150 keer per um in $90^{\circ}$

Gebruik van de nek is nict beperkt

Reiken 500 keer per uur $80 \mathrm{~cm}$

Werken boven schouderhoogte 4 un per werkdag een kwartier aneengesloten

Hand-en vingergebruik is niet beperkt

Tillien 150 keer per unr $20 \mathrm{~kg}$

Geen beperkingen ten aanzien wan duwen en trekken

Dragen gedurende 2 un per werkdag $25 \mathrm{~kg}$

Blootstelling an luchtverplaatsing is niet beperkt

Blootstelling am stof, rook, gas en damp is miet beperke

Blootstelling is mogelijk langer dan 5 minuten bij temperaturen van $-20^{\circ} \mathrm{C}$

Blootstelling is mogelijk langer dan 5 minuten bij temperatwen van $+40^{\circ} \mathrm{C}$

Mer dan én temperatuurwisseling wan $60^{\circ} \mathrm{C}$ binnen 5 minuten

Bloowtalling langer dan 4 uur anewngesloten an een relatieve luchtwochtighed wan $>90^{\mathrm{g}}$ is niet beperk

Blootstelling langer dan 4 ur aneengesloten aan eeru relatieve Luchrwochtigheid vari $<35 \%$ is net beperkt

Huidcontact met vaste en vloeibare stofien is miet beparkt

Blootsrelling an trillingen (ind. transport) is niet beperkt

Buiderzids gehoorverlies $<30$ ab $4 / \mathrm{m} 3 \mathrm{kHz} /<65 \mathrm{db}$ twsen $3-8 \mathrm{kHz}$

Anblyopie nc $>0.3$ andice oog $>0.8$; binoculair zien mo $>0.8$ Ishihara $>10 / 16$; daanonder verder onderzoek m.b.v de Fannsworth D 15 test

Dragen van beschermende middelen is niet beperkt

Blootstolling an persoonlijk riciso is niet beporkt (zoals bij epilepsic wal het geval is)

De psychische belasting is net beperkt (nadere specificatie stibeisen wan a-q) (Zie tabe] 14)

Voldoende conditie 


\begin{tabular}{|c|c|c|}
\hline $\mathrm{Nr}$ & Beoordelingspunt & Basismedische Eis \\
\hline 30 & Lopen met bepakking & $\begin{array}{l}\text { Kan incidented } 5 \mathrm{~km} \text { met GVTI (cerstelijn malitare bepaking) } \\
\text { in ten war afleggen }\end{array}$ \\
\hline 31 & Graven & Kan incidented een kubieke meter in twee mur gaven \\
\hline 32 & Springen & Kan wan / ower ến mo springen. \\
\hline 33 & Optreden te velde & Optreden te velde is op basaal niwean mogelijk \\
\hline 34 & $\begin{array}{l}\text { NBC (nucleaire, chennische } \\
\text { en biologische protectie) }\end{array}$ & $\begin{array}{l}\text { Kan incidented nbc-beschermende middelen gedurende án thur } \\
\text { dragen. }\end{array}$ \\
\hline 35 & Tropen & Kan in de tropen functioneren \\
\hline 36 & Spreekvandigheid & Sprecknandigheid is net beperkt \\
\hline 37 & Gesanecrd gebit & $\begin{array}{l}\text { Dental fitness Klasse } 2 \text { ( witzendbar zonder behandeling } \\
\text { gedurende } 6 \text { maanden) }\end{array}$ \\
\hline 38 & Scherfwerend vest dragen & Kan incidenteel gedurende 8 umr ean scherfwerend vest dragen \\
\hline 39 & Helm dragen & Kan incidented de helm gedurende 8 uur chragen \\
\hline 40 & Hanteren vuurwapen & Kan een handvuwrwapen hanteren \\
\hline 41 & Onregelmatig functioneren & Kan incidenteal op onregelmatige tijden functioneren \\
\hline 42 & $\begin{array}{l}\text { Verdragen Klasse I } \\
\text { (voeding) }\end{array}$ & Kan door de KL verstrekte Klasse I verdragen \\
\hline 43 & Medicatie-aflhankelijkheid & Er is geen sprake van medicatic-athankelijkheid \\
\hline
\end{tabular}

sche bijzonderheid wordt verondersteld, dan vormt die veronderstelling aanleiding om vervolgens ook het betreffende specifieke protocol bij die keuring te gaan hanteren. De consequenties van de bevindingen dienen dan vervolgens conform het gestelde in de basismedische eisen te worden afgehandeld. Alle protocollen zijn opgebouwd uit dezelfde onderwerpen: anamnese, lichamelijk onderzoek, biometrische gegevens (zoals bijvoorbeeld de bloeddruk of hartfrequentie), redenen voor verwijzing (naar specialismen of voor verder onderzoek), en in welke situaties het inwinnen wan inlichtingen geindiceerd is.

Deze keuringsprotocollen hebben geen dwingend karakter, maar wormen een methodiek om geen essentiële vragen te vergeten, geen specifiek onderzoek achterwege te laten en geen stappen in het proces van oordeelsvorming over te slaan. De individuele keurend arts behoudt de vrijheid om van het in het keuringsprotocol voorgestelde oordeel af te wijken, indien dit zorgvuldig en toetsbaar gemotiveerd wordt. Dit betekent dat de arts ten opzichte van het vorige systeem meer autonomie heeft, maar tegelijkertijd over een instrument beschikt om systematisch te werken. Een overzicht van de keuringsprotocollen wordt weergegeven in tabel 2.

Voor het ontwikkelen van zowel keuringsprotocollen als basismedische eisen is een werkverband opgericht, waarin vertegenwoordigers van bedrijfsartsen, verzekeringsgeneeskundigen en sportartsen uit de krijgsmacht zitting hadden. De normstelling van de Basismedische Eisen vond plaats op grond van de erva-m 
ring van leden (empirie), Die ervaring is waar mogelijk aangevuld met gegevens uit de vakliteratuur Zo doende zou gesteld kunnen worden dat het nieuwe keuringsinstrument aan de vereisten van "face validity" [1] voldoet. Alle keuringsprotocollen zijn ter beoordeling voorgelegd aan op betreffend terrein deskundig geachte klinisch specialisten. Hierdoor wordt aannemelijk dat bij het nieuwe keuringssysteem ook sprake is van "expert validity" [1].

Met behulp van de keuringsprotocollen wordt het onderzoek naar eventuele medische bijzonderheden uitgevoerd. Vervolgens moet worden vastgesteld of een gevonden medische bijzonderheid leidt tot beperkingen in het functioneren als militair. Dit windt plaats door toetsing van de medische bijzonderheid aan de gestelde basismedische eisen. Indien dit tot de constatering van één of meer beperkingen leidt, dan is er sprake van ongeschikt verklaring. In figuur 1 wordt de te hanteren werkwijze schematisch weergegeven.

Welke verschillen bestaan er uiteindelijk tussen het nieuwe en het oude keuringssysteem? Het oude keuringssysteem ("ABOHZIS") was diagnosegericht en verplichtte de keurend arts om ziekten en gebreken te determineren, waaruit een indelingadvies volgde. Bekend was dat dit systeem geen relatie met de feitelijke militaire werkzaamheden vertoonde [14]. Er bestonden geen functie-eisen, noch werd rekening gehouden met specifieke militaire vaardigheden. In de loop van de tijd verdween de medische aandacht voor de psychische belastbaatheid. De arts beoordeelde of er sprake was ziekten of gebreken, aan de hand waarvan men werd goed - of afgekeurd, ongeacht of men aan de bepaalde functie-eisen voldeed (deze ontbraken immers).

Het nieuwe keuringssysteem ("BMEKL") is functiegericht en volgens het model belasting-belastbararheid [13] afgeleid van de concrete eisen, te stellen aan militairen [51]. Deze eisen omvatten het complete scala aan taken met inbegrip van operationele inzet, rekening houdend met specifieke militaire vaardigheden en de mate van psychische belastbaarheid. Hierbij wordt gekeken of de gevonden medische bijzonderheden tot beperkingen leiden in het minimal vereiste operationele functioneringsniveau. Is dit het geval dan word men ongeschikt bevonden. Daarbij kan nog worden aangetekend dat de eisen van het BMEKL-systeem objectiveerbaar zijn. In geval een kandidaat meent dat de uitslag niet klopt, dan kan deze in de gelegenheid worden gesteld om het gelijk aan te tonen. Ter illustratie daarvan komt het voor dat iemand bij de pensioenkeuring wordt afgekeurd (zowel het oude als het nieuwe keuringssysteem werd zowel voor de anstellingskeuring als voor de pensioenkeuring gebruikt) op grond van thet niet langer een mars met bepakking te kunnen volbrengen. In geval deze persoon de uitspraak betwist, wordt overgegaan tot het aanbieden van een meerdaags programma waarin dat vermogen in de praktijk wordt getest. 
Thbel 2. De ontwikkelde keuringsprotocollen

\begin{tabular}{|c|c|}
\hline Nr & Inhoud \\
\hline$\Downarrow$ & Standaard-anamnese, lichamelijk onderzoek en bionetrische gegeverns. \\
\hline 2 & De beoordeling van het gebruik pan geneesmiddelen \\
\hline 3 & Het onderzoek van de voeten \\
\hline 4 & Het onderzoek wan de enkels \\
\hline 5 & Het onderzock van de onderbenen \\
\hline 6 & Het onderzoek wan de knieën \\
\hline 7 & Het onderzock van de bowenbenen en de liezen \\
\hline 8 & Het onderzoek van de heupen \\
\hline 9 & Het onderzoek van wervelkolom, nek en Sacro-lincale gewnchten \\
\hline 10 & Het onderzoek van de schoudergordels \\
\hline $\mathbb{1 1}$ & Het onderzoek van de bowenarmen \\
\hline 12 & Her onderzoek van de ellebogen \\
\hline 1.3 & Het onderzoek van de onderamen \\
\hline 14 & Het onderzock van de polsen \\
\hline 15 & Het onderzock van de handen en vingers \\
\hline 16 & Het neurologisch onderzoek \\
\hline 17 & Het onderzoek van de luchtwegen \\
\hline 18 & Het onderzoek van het hart en de bloedsomoop \\
\hline 19 & Het onderzoek van de tractus digestivus \\
\hline 20 & Het onderzoek van de tractus urogenitalis \\
\hline 21 & Het dermatologisch onderzoek: \\
\hline 22 & Het onderzoek van het gehoor \\
\hline 23 & Het onderzoek van de visus \\
\hline 24 & De beoordeling van endocrinologische andoenangen \\
\hline 25 & Het piychiatrisch onderzoek \\
\hline 26 & Het onderzoek van het bloed en de bloedwormende organen \\
\hline
\end{tabular}

Samengevat: kon de keurend arts vroeger na de vaststelling van een bepaalde ziekte of gebrek in een voorschrift opzoeken of daarmee de kandidaat wel of niet geschikt was, thans moet de arts met behulp van protocollen de onderzoeksbevindingen toetsen aan de functie-eisen en verwolgens afwegen of dat tot beperkingen ten aanzien van de gestelde eisen leidt of niet. In tabel 3 worden de belangrijkste verschillen op een rij gezet. Daarmee wordt een voorschot genomen op de vraag of het nieuwe keuringssysteem all dan niet voldoet aan de 


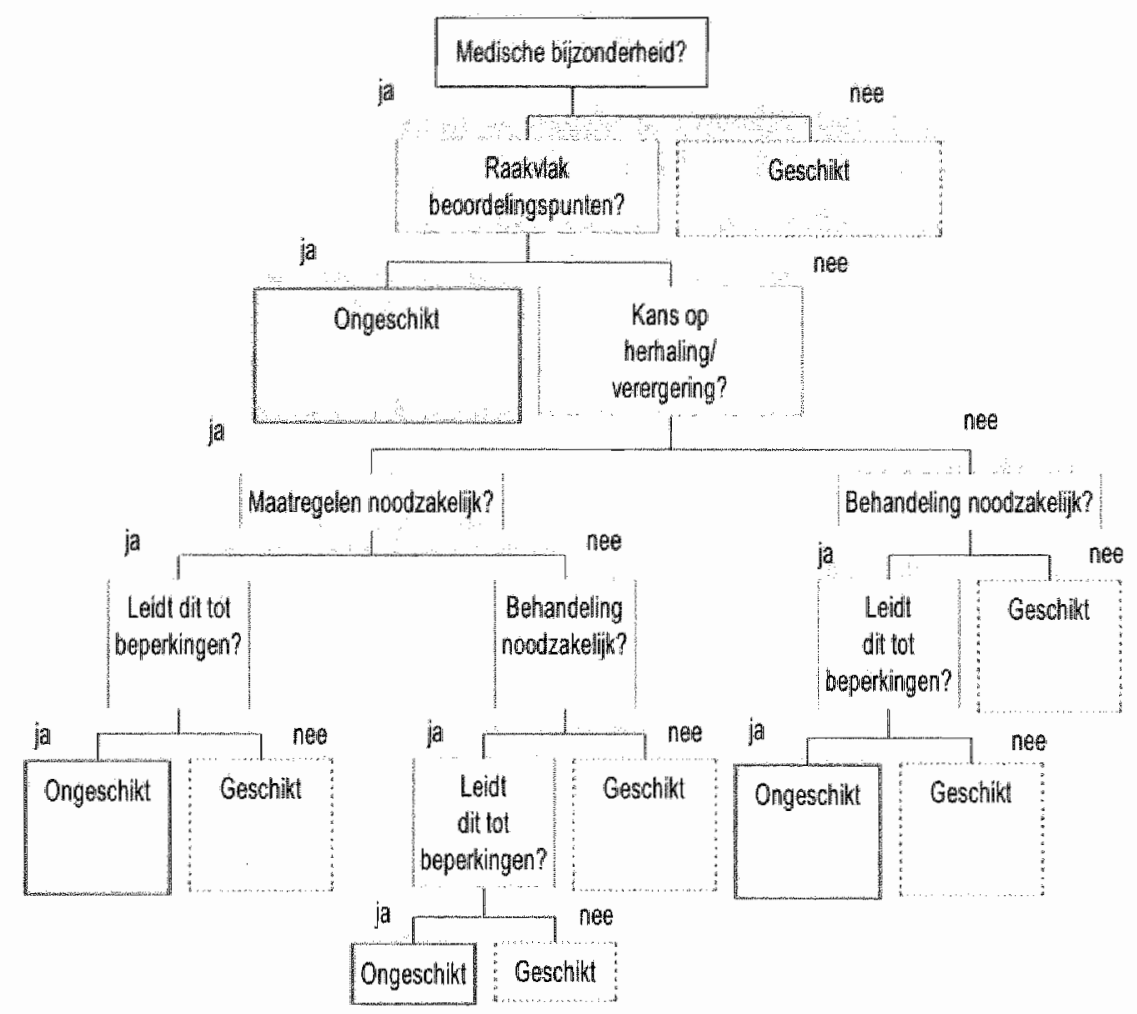

Figuur 1: Beslissingrschema bij het nieuwe (BMEKL) keuringssysteem.

eisen, gesteld door de WMK. Aan het beantwoorden van deze laatste vrag wordt in de volgende paragraf aandacht geschonken.

\subsubsection{Voldoet het nienwe systeem aan de WMK en de ARA?}

Na de ingebruikneming van dit nieuwe systeem diende te worden beoordeeld of nu voldan was aan het in de WMK gestelde. Bovendien was ansluitend op de WMK inmiddels ook Algemene Richtlijn Aarstellingskeuringen (ARA) ontwikkeld [50], terwijl een aantal bepalingen uit de WMK nog extra werden belicht door de publicatie in 2001 van de Statsbladen 597 en 598 . In Staatsblad 597 worden nogmaals alle relevante toetsingscriteria opgesomd, waaraan bij het verrichten van een anstellingskeuring moet worden voldaan. In Staatsblad 598 wordt en onathankeljke klachtencommissie ingesteld. 


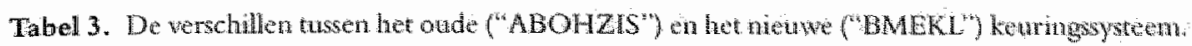

\begin{tabular}{|c|c|c|}
\hline & ABOHZIS & BMEKL \\
\hline Model & Ziekten en gebreken & Belasting belastbathed \\
\hline Functie-eisen & Nee & $\int \mathrm{an}$ \\
\hline Relatie met takstelling & Nee & Ja, daanan afguleid \\
\hline Specifeke militaire vaardigheden & Nee, diagnosexericht & fia \\
\hline Psychische belastlaarheid & Nict of namwelyiks & la \\
\hline Conplete afdekking & Nee & Ja \\
\hline Beoordelingskader & Afwerig & Aanwezig \\
\hline Geprotocolleerd & Nee & Ia \\
\hline Objectiveerbaar & Afhanketijk van oorded arts & ${ }_{\text {Ja }}$ praktisch alle eisen \\
\hline Voldoet an WMK & Nee & Jal \\
\hline
\end{tabular}

Teneinde de BMEKL te toetsen aan WMK en ARA worden hieronder de vragen, zoals vermeld in het stappenplan van de ARA, achtereenvolgens beantwoord.

\section{Zijn er functie-eisen met ongewoon hoge belasting?}

Gelet op het in de documentatie van de basismedische eisen en de keuringsprotocollen vermelde, mag dit bevestigend worden beantwoord. Ook de werkgever geeft, zoals reeds eerder is opgemerkt, te kennen dat de samengestelde functie van de militair ambtenaar "zware fysieke en geestelijke eisen" met zich meebrengt.

Op grond van die "zware fysieke en geestelijke eisen" zijn door de werkgever met behulp van deskundigen - in de loop van 1997 de "Militaire Basiseisen KL" opgesteld. Deze basiseisen geven een compleet overzicht van de concrete belasting die zich in het functioneren als militair ambenaar minimal voordoen. Deze basiseisen zijn vervolgens op medisch gebied geoperationaliseerd.

Vervolgens resteert de vraag tot welke ARA-klassering de bijzondere eisen ten aanzien van de medische geschiktheid voor de functie behoren. Dit kan variëren van afwezig (klasse 1) tot zeer zwaar (klasse 5). Gelet op het over de eisen gestelde in de Memorie van Toelichting bij de Wijziging op de Wet op de Medische Keuringen alsmede de concrete operationele taakstelling, kan worden aangenomen dat de eisen voor de militair ambtenaar een aanstellingskeuring rechtvaardigen en dat de eisen global op het niveau 5 van de ARA liggen. Bovendien zijn voor de militair ambtenaar nog meer eisen te formuleren dan die in de ARA als voorbeeld zijn bijgeleverd (zoals het moeten kunnen 
hanteren van een wurwapen), warvoor basismedische eisen als bewijs kunnen gelden.

Is die belasting niet wet gangbare maatregelen te reduceren?

Er is thans een Convenant Fysieke Belasting afgesloten tussen de Ministeries wan Sociale Zaken en Werkgelegenheid en Defensie. In dat kader wordt onderzoek bij de krijgsmacht verricht naar mogelijkheden om op het terrein van fysieke belasting verbeteringen door te voeren. Hierbij kan worden gedacht aan tilhulpmiddelen en een lichtere standaarduitrusting. Tevens wordt onderzoek verricht naar de gebruikelijke training zoals deze bij opleiding en oefeningen voorkont, met als doell om blessures te reduceren. Verder kan de operationele noodzaak voor met name de fysieke belasting slechts als een voldongen feit worden beschouwd: de bepakking van een infanterist weegt nu eemmal veel, evenals het huidige scherfwerend vest. Ook nar de psychische belasting wordt veel onderzoek verricht; hieruit blijkt dat in de praktijk na elke uitzending een aantal militairen geestelijke schade op heeft opgelopen.

Is er een visico op gezondheidsschade?

De verschillende eisen (zoals diverse vormen van lichamelijke inspanning, schieten, tactisch optreden te velde) kunnen samengevat tot hetzelfde risico leiden: uitval bij de eenheid tijdens operationeel optreden, waardoor men zichzelf en/ of de eenheid in gevaar brengt. Dit risico kan onder meer worden uitgesplitst naar: bedrijfsongevallen (zwaar en gevaarlijk materiaal), verkeersongevallen (verplaatsingen en tactisch optreden in oneffen terrein onder moeilijke omstandigheden), blessures (die de eenheid ophouden), het gebruik van vuurwapens, de kans op gijzeling, het plegen van gevechtshandelingen, het gebruik van beschermende middelen zoals helmen en scherfwerende vesten of het dragen van luchtmaskers plus beschermende kleding tegen chemische aanvallen.

Deze risico's worden klassiek geformuleerd als: schade voor de eigen gezondtheid en weiligheid of voor die van derden. Om deze risico's te elimineren dient een militair op tekortkomingen die tot deze uitval kunnen leiden te worden beoordeeld, in relatie tot de operationele takstelling.

Subcondusie: Op grond van het bovenstaande wordt aan het in Artikel 4 van de WMK vermelde noodzakelijkheidcriterium voldaan.

\section{Zijn de eisen te vertalen in gezondheidscriteria?}

Hiervoor is de procedure ingevoerd conform Figuur 1, schriftelijk weergegeven in de vorige paragraaf. De arts verzamelt medische bijzonderheden op geprotocolleerde wijze en weegt deze ten opzichte van de geoperationaliseerde basis- 
medische eisen. Leidt dit tot de constatering dat er wan een beperking sprake is, dan zal het ongeschiktheidoordeel worden uitgesproken. Dit geeft de keurend arts geen vrijbrief om om het even welke medische bijzonderheid als een beperking ten aanzien van de BMEKL te beschouwen. Juist de formulering en normering van de eisen begrenst de professionele autonomie tot het gewenste terrein: alleen medische bijzonderheden die ten opzichte van de geformuleerde eisen gesignaleerde beperkingen opleveren tellen mee in de oordeelsvorming.

Subconclusie: Gelet op de documentatie van de BMEKL en de keuringsprotocollen zijn de eisen te vertalen in gezondheidsrisico's.

\section{Is medisch onderzoek mogelijk?}

\section{Zijw er normen?}

In de BMEKL zijn bij alle 43 beoordelingspunten duidelijke normen aangebracht. De gehanteerde methoden leveren geen risico voor de lichamelijke of geestellijke gezondheid voor de keurling op. Bij het onderzoek naar het al dan niet voldoen aan de gestelde eisen, wordt gebruik gemaakt van protocollen.

\section{Vorwt de gehanteetde methode een valide indicator?}

De gehanteerde eisen zelf en de keuringsprotocollen (hoe onderzoek naar de bijzonderheden te verrichten) zijn ontwikkeld door een krijgsmachtbrede combinatie van bedrijfsartsen, verzekeringsgeneeskundigen, sportartsen, en bewegingswetenschappers. In paragraaf 1.4.1 is aannemelijk gemaakt dat voor het nieuwe keuringssysteem sprake is van zowel "face validity" [1] als van "expert validity" [1].

De sensitiviteit en specificiteit van het keuringssysteem zijn niet bekend. Van de gehanteerde meetinstrumenten om medische bijzonderheden op te sporen (bijwoorbeeld voor visusbepaling) is de validiteit niet bekend, hooguit kan worden gesteld dat deze instrumenten standaard in ons land worden gehanteerd. Voor de gedetailleerde weergave van de aanstellingsprocedure en daarbij gehanteerde meetinstrumenten wordt naar de paragraaf "Achtergrondinformatie" van hoofdstuk 4 verwezen.

Is de gehanteerde methode proportioneel?

In het keuringsproces wordt eerst naar medische bijzonderheden bij cle kandidaat gezocht door middel van anamnese, aanvullend onderzock en lichamelijk onderzoek. Vervolgens wordt beoordeeld of een eventueel gevonden medische bijzonderheid tot een beperking ten aanzien van de BMEKL leidt. Die toetsing aan de BMEKL kan zonder meer als proportioneel worden beschouwd: de normen zijn afgeleid van de aan militairen te stellen eisen. Resteert de vraag of het onderzoek naar medische bijzonderheden proportioneel is. De anamnese is 
enige jaren geleden reeds getoetst op proportionaliteit en waar nodig aangepast ${ }^{3}$. Behoudens die anamnese wordt een aantal instrumenten gehanteerd om aanvullend bepaalde specifieke (vooral zintuiglijke) kwaliteiten te onderzoeken, zoals het gehoor, de visus en het kleuronderscheidend vermogen. Dit geldt in feite ook voor het onderzoek naar de kwaliteit van het bewegingsapparaat door de fysiotherapeut voorafgaande aan het bezoek aan de keurend arts. Gelet op de ten tijde van het opstellen van het keuringssysteem beschikbare keuringsgegevens is destijds aangenomen dat het gebruik van het instrumentaritum aan het proportionaliteitscriterium voldeed, maar het kan niet worden uitgesloten dat toekomstig onderzoek tot andere inzichten zal leiden.

Is de gehanteerde methode subsidiair?

Voor al het gebruikte instrumentarium kan worden aangenomen dat dit subsidiair is. Anamnese en lichamelijk onderzoek kunnen de toets der kritiek doorstaan; voor bij de overige onderzoeken gehanteerde methoden bestaan geen minder ingrijpende methoden, noch is het aannemelijk dat het gebruik van die methoden zelf als te ingrijpend zal worden ervaren.

Leiden de onderzoeksmethoden niet tot ongerechtvaardigde differentiatie en discriminatie van groepen in de samenleving?

Het doel van de BMEKL is om onderscheid te maken tussen een operationeel wel en niet inzetbare militair ambtenaar. De in de begeleidende documentatie van BMEKL en keuringsprotocollen vermelde gegevens geven geen aanleiding om aan te nemen dat er in deze werkwijze sprake is van ongerechtvaardigde discriminatie.

Is het te verichten onderzoek relevant voor het verwezenlijken van het doel wan de keuring (relevantiecriterium)?

Hierbij past een zelfde redenatie als bij de vraag naar proportionaliteit het geval was. Gelet op de ten tijde van het opstellen van het keuringssysteem beschikbare keuringsgegevens is destijds aangenomen dat het gebruik van het instrumentarium aan het relevantiecriterium voldeed, maar het kan niet worden uitgesloten dat toekomstig onderzoek tot andere inzichten zal leiden.

Subondusie: Voor zover redellikerwijze te beoordelen valt, is medisch onderzoek mogelijk.

3 Nar andeiding van wagen uit de Tweede Kamer heef een intem werkverband bepalde vragen uir de anamnese geschrapt. 


\section{Is keuren toegestan?}

Zijn de eisen door een bedrifsarts watgesteld?

De vertaling van de bijzondere functie-eisen is primair de taak van de bedrijfsarts. Dit is bij het opstellen van de BMEKL ook het geval geweest.

Is keuren toegestaan?

Er zijn functie-eisen met een ongewoon hoge belasting, meer zelfs dan in het voorbeeld van de ARA zijn opgenomen. Al deze eisen vallen volgens het ARA-voorbeeld in de zwarste klasse. Deze eisen zijn te vertalen in gezond heidscriteria. Ook medisch onderzoek is mogelijk. Het keuringssysteem voldoet aan de vereisten voor face-validity en expert-validity, maar door het ontbreken van de sensitiviteit en specificiteit kan de validiteit van het keuringssysteem niet worden angetoond; dit is overigens bij geen enkel keuringssysteem in Nederland her geval. Een voorbehoud moet voorts worden gemakt ten aanzien van het proportionaliteitscriterium en het relevantiecriterium. Het kan niet worden uitgesloten dat het gebruik van bepaald onderzoeksinstrumentarium (visus, gehoor etc.) nar aanleiding van toekomstig onderzoek zou moeten worden bijgesteld. Het systeem is immers twee jaar voor de invoering van de ARA ontworpen. De eisen zijn door bedrijfsartsen opgesteld; de te hanteren werkwijze wordt ondersteund door protocollen.

Conchsie: Gelet op het onder de stappen 1 tot en met 4 betoogde valt het te verantwoorden dat voor een anstelling bij de $\mathrm{KL}$ als militair ambtenar een aanstellingskeuring wordt verricht, mits nog nader onderzoek wordt uitgevoerd (naar de validiteit, proportionaliteit en/ of relevantie van bepaalde meetinstrumenten, evenals naar het uiteindelijke effect van het Convenant Fysieke Belasting tussen de Ministeries van SZW en Defensie).

Op de volgende pagina is met behulp van Figuur 2 het stappenplan ten anzien van de functie voor militair ambtenaar schematisch weergegeven.

\subsection{Theorie, hypothese en vraagstelling}

\subsubsection{Theorie}

Volgens Bouter en Van Dongen [1] ontstat een theorie door inductic van warmemingen. Voor wat keuringen betreft zijn die warnemingen in de voorgaande paragrafen weergegeven. De bewijslast van deze warnemungen is overtuigend genoeg om er een theorie an te ontlenen. Deze theorie luidt dat de kualiteit wan aanstellingskewringen ats meetinstrwment te wensen over laat. 
Fumetie: militair ambienaar

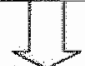

Functemeisen met ongewoon hoge belasting, net met gewone gangbare

maluregelen te reduceren, waandoor grote kan:s op gezondheidsschade?

a) Wethelijk werplicht on schade aan eigen gezondheid en veitigheid, dan wel die van anderen te voorkonen

b) Uzzondering in de Wijziging op de Wet op de Medische Keuringen waarbi "zware fysioke en geestelike eisen" worden aangenomen

c) Operationelle taakstelling, met vooraf onbekende risico's (vanaf peacekeeping operaties $\mathrm{Um}$ grootschalig conflict)

d) Speciffek: scherfwerend vest, helm, vuunwapen, nbc-omstandigheden. velidwerk, zwaar materieel, werktjden, woeding

e) Zware fysieke training en opleiding

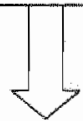

JA

2

Te vertalen in 43. 1sieke en psychische beoordelingspunten

JA

Medisch onderzoek mogelijk?

(expert en face) valide indicatoren subsidiair en proportioneel genormeerd (BMEKL zijn de normen) niet discriminerend, relewant geprotocolleerd

Vertalald door bedrifsartisen

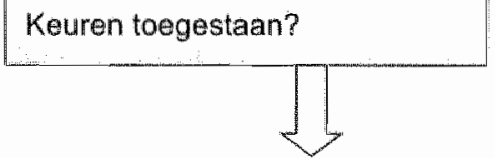

JA

Figute 2:Schenatiscli overzich van de volgens de AR A te beantwoonden vragen om te mogen kcuren.

Het antal atkeuringen is vak erg laag, hetgeen de vraag oproept warom er moet worden gekeurd $[16,18]$. Ook de reproduceerbaarheid is vaak te laag $[2$, $19,24,25]$. De relatie tussen medische bijzonderheden en uitval op het werk 
ontbreekt $[17,39]$, onderzoek naar andere kwaliteitsmaatstaven dan de reproduceerbaarheid ontbreekt feitelijk $[16,17]$, onder meer omdat dit moeilijk te verwezenlijken valt.

\subsubsection{Hypothese}

Mede op grond van bovengenoemde waarnemingen is de WMK in ons land ingevoerd. Door voorwarden te werbinden aan het mogen uitvoeren van keuringen, beoogt de WMK de kwaliteit van keuringen te verbeteren.

In paragraaf 1.3.1 is uiteengezet dat ook op het ABOHZIS-keuringssysteem de nodige kritiek te leveren viel; zo voldeed dit systeem niet ann de vereisten die door de WMK worden gesteld.

Uit de voorgaande paragraaf blijkt dat het nieuwe keuringssysteem - de BMEKL - in hoofdzaak aan zowel WMK als ARA voldoet. Hypothetisch zou dit moeten betekenen dat de kwaliteit van het BMEKL-keuringssysteem beter zou moeten zijn dan die van het ABOHZIS-systeem.

Vervolgens moeten nu de onderzoeksvragen worden geoperationaliseerd.

\subsubsection{Operationalisering van de onderzoeksvragen}

\section{Inleiding}

De hypothese is dat de kwaliteit van het BMEKL-keuringssysteem beter zou moeten zijn dan die van het ABOHZIS-systeem. Hoe kunnen nu vanuit deze hypothese de onderzoeksvragen worden geoperationaliseerd? Uitgangspunt is dat onderzoek dient plats te vinden naar de kwaliteit van keuringen. In de eerste plaats zal daarbij aandacht moeten worden besteed aan de vraag welke kwaliteitscriteria voor de keuring te onderscheiden vallen. Wellicht moet daaruit een keuze worden gemaakt. Vervolgens zal een onderzoekspopulatie moeten worden gekozen. Bekeken zal moeten worden welke metingen bij die populatie moeten worden verricht om de gekozen kwaliteitscriteria té onderzoeken. Uiteindelijk zal moeten worden nagegaan onder welke omstandigheden die metingen bij de onderzoekspopulatie moeten worden verricht.

\section{Kualiteit}

Een keuring is een meetinstrument of diagnostische test. De kwaliteit van een diagnostische test is afhankelijk van verschillende testeigenschappen. Bouter en Van Dongen [1] onderscheiden er vijf.

- De relevantie van het met behulp van de test gemeten kenmerk. Bouter en Van Dongen [1] definiëren dit als volgt: het kenmerk (bijwoorbeeld pijn) moet betekenisvol zijn, gegeven het doel dat met de toepassing van de testprocedure wordt beoogd (bijvoorbeeld vaststellen of een ziekenhuisopname is geindiceerd). 
- De praktische toepasbaarheid. De test moet zijn toegesneden op de praktijksituatie warin hij wordt toegepast (kenmerken van de populatie: aantal, beschikbare tijd, leeftijd overwegend gezond; kenmerken van de onderzoeker: vardigheid, beschikbare tijd). Afhankelijk van de onderzoekssituatie dienen eisen te worden gesteld aan onder andere het tijdsbeslag, de complexiteit en de and de test verbonden risico's.

- De efficientie, de mate warin de gevraagde inspanning en de gemaakte kosten zo laag mogelijk blijven.

- De reproduceerbaarheid, waarbij de onderlinge variatie in beoordelingen zo klein mogelijk dient te zijn.

- De validiteit; de test dient het diagnostische kenmerk zo nauwkeurig mogelijk te meten en derhalve een zo hoog mogelijke sensitiviteit en specificiteit te bezitten.

Eerder is echter reeds vermeld dat het ABOHZIS-systeem geen relatie meer vertoonde met de feitelijke aard van de werkzaamheden [14], terwijl het BMEKL-systeem juist was afgeleid van die feitelijke werkzaamheden [51]. Theoretisch zou daarmee de relevantie van het nieuwe systeem hoger moeten uitvallen dan het vorige ABOHZIS-systeem, maar aangetoond is dat niet.

In paragraaf 1.4 .2 is uiteengezet dat bij de aanstellingskeuring van een aantal meetinstrumenten gebruik wordt gemaakt. Bij de overgang van het ene keuringssysteem naar het andere is daarbij geen verandering gekomen. Door de keuringsprotocollen en het beoordelingskader is de beschouwing wel gewijzigd: in plaats van diagnose-gericht te oordelen, wordt in het nieuwe systeem volgens het model van belasting - belastbaarheid beoordeeld of iemand voldoet aan de te stellen eisen, die zijn ontleend aan de realiteit. Waar de praktische toepasbaarheid van het ABOHZIS-systeem door het decennialange gebruik ervan (vanaf 1946 tot 1997) empirisch is aangetoond, kan op theoretische gronden worden aangenomen dat die van het nieuwe systeem tenminste even goed en wellicht iets beter zal zijn. Ook dit is echter niet aangetoond.

Ook qua efficiëntie zullen beide systemen elkaar weinig ontlopen. Er wordt van dezelfde instrumenten, personen en infrastructuur gebruik gemaakt. Voor de ingebruikneming van de BMEKL zijn geen meerkosten gemaakt, terwijl het nieuwe keuringsproces zelf ook niet meer tijd in beslag neemt dan het vorige. Het opleiden wan de betrokken artsen vond plaats gedurende twee workshops in het voorjaar van 1998, waarbij de opkomst $98 \%$ was. Na afloop gaven alle bij de aanstellingskeuring betrokken artsen in de schriftelijke evaluatie aan van mening te zijn zonder verdere begeleiding met het nieuwe systeem te kunnen werken. De speciaal daarvoor in het leven geroepen helpdesk ontving tot aan het begin van het onderzoek uit dit proefschrift (oktober 1998) geen vragen. 
De reproduceerbaarheid, betroumbarheid of consistentic is de mate van overeenstemming tussen testuitslagen, meermalen toegepast bij dezelfde onderzoekspersonen onder gelijkblijvende condities. Dit vormt een graadmeter voor de kwaliteit van de diagnostiek.

De reproduceerbarheid kan op verschillende manieren worden beoordeeld. $Z$ o kan worden onderzocht of éen warnemer die de test bij dezelfde personen herhaalt, steeds tot dezelfde bevindingen komt (intra-waamemers variatie, test-retest reliability). Hierbij moet voldoende tijd tussen de metingen zitten om herkenning te voorkomen, maar een te lange tussentijd kan werkelijke veranderingen inhouden. Ook kan worden onderzocht of twee warnemers die de test - liefst gelijktijdig - bij dezelfde personen uityoeren tot gelijkluidende concinsies komen (inter-warnemers variatie, inter-observer reliability).

De reproduceerbaarheid kan met behulp van verschillende maten worden onderzocht [1,2], af te leiden van onderstaande kruistabel (tabel 4). Op deze maten zelf en de daaraan soms verbonden beperkingen $[1,52,53]$ wordt in de hoofdstukken 2 tot en met 4 nader ingegaan. Hier wordt volstan met op te merken dat volgens Bouter en van Dongen [1] de kappa én van die maten is (uitslag minimaal 0,0 tot maximaal 1,0 ). Volgens deze auteurs suggereren gepubliceerde onderzoeksgegevens dat een kappa tussen de 0,40 en 0,75 voor diagnostische testen in de klinische diagnostiek gebruikelijk is.

Ondat zowel het oude als het nieuwe keuringssysteem niet alleen bij de anstellingskeuring wordt gehanteerd, maar tevens bedoeld is als instrument voor de pensioenkeuring, moet voor beide vormen van keuring de reproduceerbaarheid worden nagegan.

Als met beoordelaar 1 en 2 twee verschillende onderzoekers worden bedoeld, kan de inter-warnemers variatie worden berekend. Als met beoordelar 1 en 2 dezelfde onderzoeker wordt bedoeld, kan de intra-warnemers variatie worden berekend.

Het ABOHZIS-keuringssysteem is onderzocht op reproduceerbaarheid (hoofdstuk 2). De uitslagen van de twee darbij gehanteerde maten voor overeenkomst waren vergeligkbar met de uitslagen van het onderzoek wan Post-Uiterweer en De Kort [2]. Het BMEKL-systeem is nog niet onderzocht op reproduceerbaarheid.

De gangbare maten om de validiteit wan een test te bepalen, zijn de sensitiviteit en de specificiteit. Sensitiviteit geeft het percentage mensen met een bepalde ziekte die door de test terecht als ziek worden geclassificeerd; sensitiviteit zegt dus iets over de gevoeligheid van de test voor het herkennen van zixktegevallen. De specificiteit geeft het percentage mensen aan dat terecht als niet ziek wordt geclassificeerd. Een goede test scoort meer dan $90 \%$ op zowel de sensitiviteit als de specificiteit [1]. Dit wordt in tabel 5 weergegeven. 


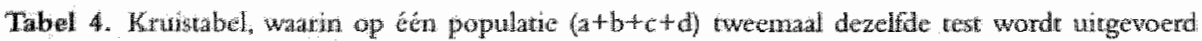
door ofwel twee verschillende beoordelars (1 en 2), ofwel rwe mal achtereen door dezelfde beowrdelar.

Beoordelaar 2

Nomale testuritag AFwikende testuitslag

Beoordetian 1

Normale testuirslag

Afwijkende testuirslag

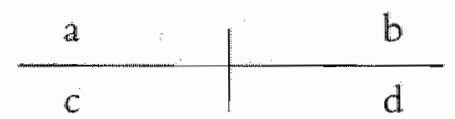

Tabel 5. Kruigabel warm een zitkte of kermerk met behulp van een test op de aan- of afwezigheid binnen een populatie (atb+ctd) wordt beoordedd, terwijl deze ziekte of kenmerk reeds aerder is vastgesteld met een andere test die over de an- of afwezigheid daarvant absolunt uitslwitsel werschaft.

Ziekte

\begin{tabular}{|c|c|c|c|}
\hline & Aanwezig & Afwezig & \\
\hline Positief & $\begin{array}{l}\text { terechto-positief } \\
\text { a }\end{array}$ & $\begin{array}{l}\text { fout-positzef } \\
\text { b }\end{array}$ & $a+b$ \\
\hline Negandet & $\begin{array}{l}c \\
\text { fout-negaltief } \\
a+c\end{array}$ & $\begin{array}{l}d \\
\text { terecht-negatief } \\
b+d\end{array}$ & $\begin{array}{l}c+d \\
a+b+c+d\end{array}$ \\
\hline
\end{tabular}

De sensitiviteit wordt vervolgens uitgedrukt als $\mathrm{Se}=\mathrm{a} /(\mathrm{a}+\mathrm{c})$. De specificiteit wordt vervolgens uitgedrukt als $S p=d /(b+d)$.

Om de validiteit te kunnen berekenen moet er zekerheid bestaan omtrent de begrippen "terecht" en "fout", er moet een test bestaan die daarover in absolute zin uitsluitse] verschaft. Zo'n test wordt de "gouden standaard" [1] genoemd. Van zowel het ABOHZIS-systeem als het BMEKL-systeem is de validiteit niet onderzocht.

In tabell 6 wordt een inschatting van de stand van zaken met betrekking tot de vijf kwaliteitsmaatstaven voor beide keuringssystemen weergegeven.

De Kort [17] en diens mede-onderzoekers beperkten zich tot de betrouwbaarheid en de validiteit als graadmeters voor de kwaliteit van de medische aanstellingskeuring als selectie-instrument. Dit doet vermoeden dat door De Kort [17] an deze kwaliteitseisen van het instrument anstellingskeuring meer gewicht werd toegekend dan aan andere. Tevens blijkt uit tabel 6 dat juist kennis van die specifieke kwaliteitseisen in deze situatie gebrekkig is. Op grond hiervan is het voor deze studie plausibel om juist onderzoek te verrichten naar de reproduceerbaarheid en de validiteit. Met behulp hiervan zal worden nagegaan of het 
Tabell 6. Inschatting van de stand van zaken met betrekking tot de kwaliteitsisen ten wanzien wan beide keuringsystemen voorafgande an de onderzoeksvraag:

\begin{tabular}{|c|c|c|c|}
\hline $\begin{array}{l}\text { Kwaliteitskermerk } \\
\text { Keuring }\end{array}$ & ABOHZIS & BMEKL & Toelichting \\
\hline Relevancie & \multicolumn{2}{|c|}{ Vermoedelijk grelijkwaardig } & $\begin{array}{l}\text { Gemeten kenunerl moet betekenis } \\
\text { hebben gelet op het met de test } \\
\text { beoogde doel }\end{array}$ \\
\hline Toepasbaratheid & \multicolumn{2}{|c|}{ Vermoedelijk gelijkwaardigg } & $\begin{array}{l}\text { Toegesneden op situatic, proportioned, } \\
\text { subsidiair, voor alle partigen acceptabel } \\
\text { (implementatie) }\end{array}$ \\
\hline Efficientic & \multicolumn{2}{|c|}{ Vermoedelijk gelijkwaardig } & $\begin{array}{l}\text { Minimalisering van inspanningen en } \\
\text { unitgaven }\end{array}$ \\
\hline Validirent & \multicolumn{2}{|c|}{ Beide onbekend } & 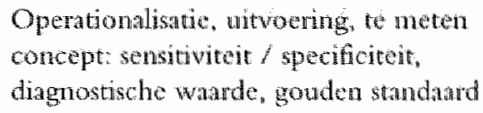 \\
\hline Reproduceerbaarheid & Laag & Onbekend & $\begin{array}{l}\text { Intra-warnemers en inter-wharnemen } \\
\text { variatic }\end{array}$ \\
\hline
\end{tabular}

nieuwe instrument beter volstaat dan het oude. Bij een eventueel gevonden verschil zal vanzelfsprekend worden getracht on het mechanisme daarvan te achterhalen. Het primaire doel is echter om de kwaliteit van het nieuwe keuringssysteem te vergelijken met die van het oude.

Voor onderzoek naar de validiteit van één of meer keuringssystemen ontbreekt de gouden standaard, waardoor het inzicht inzake de fout-positieven en fout-negatieven ontbreekt. Er is dus niet bekend wie de "ziekte" (of in dit geval het kenmerk dienstongeschiktheid) wel of niet bezit. In dat geval is men geïnteresseerd in de voorspellende waarde van de test. De voorspellende waarde geeft de kans aan dat personen met de betreffende testuitslag de ziekte of het kenmerk bezitten of in de toekonst zullen bezitten (tabel 7).

Op grond van de testuitslag is een voorspelling mogelijk ten aanzien van de aanwezigheid, respectievelijk afwezigheid van een ziekte of het kenmerk (in dit onderzoek de dienstgeschiktheid).

Daarbij geeft een positieve voorspellende waarde (DW + ) an welk deel van de onderzochte personen met een positieve testuitslag de ziekte of het kenmerk heeft, en een negatieve voorspellende waarde (DW-) welk deel van de onderzochte personen met een negatieve testuitslag van de ziekte of het kenmerk gevrijwaard is gebleven.

Hoe groter de sensitiviteit en specificiteit zijn, des te groter is de positieve en negatieve voorspellende waarde van de test [1]. De voorspellende warde is echter ook afhankelijk van de prevalentie van de ziekte of het kenmerk in de onderzoekspopulatie [1]. In het algemeen geldt: hoe hoger de prevalentie, des te 
Tabel 7. Kruistabel warin de poorspellende waade binnen een populatie $(a+b+c+d)$ wordt angegeven woor het betitten of venkijgen van een bepalde ziekte of kennerk.

Ziekte:

\begin{tabular}{|c|c|c|c|}
\hline & Aanowezig & Afwezig & \\
\hline Testuitslag positier & $\mathrm{a}$ & $b$ & $D W+=a / a+b \times 100 \%$ \\
\hline Testuirsilag negatief & $c$ & $d$ & $\begin{array}{l}\mathrm{DW}-\mathrm{d} / \mathrm{c}+\mathrm{d} \mathrm{x} 100 \% \\
\text { (negatieve woorspllende waarde) }\end{array}$ \\
\hline
\end{tabular}

groter de positieve voorspellende waarde en des te kleiner de negatieve voorspellende waarde, en vice versa [1].

In de ideale onderzoeksopzet worden groeperingen kandidaat-militairen volgens één of beide systemen gekeurd en vervolgens aangenomen, opgeleid en ingezet - onafhankelijk van goed- of afkeuring (Figuur 3).

Het te werk stellen van ongeschikt verklaarde militairen was echter geen haalbare optie. Om praktische en ethische redenen geeft de $\mathrm{KL}$-organisatie hiervoor geen toestemming.

$\mathrm{Nu}$ zou er toe kunnen worden overgegaan om de afgewezen kandidaten op dezelfde wijze te volgen gedurende dezelfde onderzoeksperiode als hun geschikt bevonden collega's. Hierbij zouden zich drie problemen voordoen. Ten eerste waren de mogelijkheden om gegevens over bij de KL te werk gestelde militairen te verzannelen aanmerkelijk uitgebreider dan die voor de externe onderzoeksgroep. Hierdoor zou selectiebias optreden. Ten tweede zouden de arbeidsomstandigheden en functie-eisen van die externe onderzoeksgroep grote individuele variatie vertonen. Door de te verwachten selectiebias zou hiervoor niet kunnen worden gecorrigeerd. Als derde zou het verkrijgen van voldoende respons problematisch kunnen blijken te zijn.

Hierdoor resteerde alleen de mogelijkheid om onderzoek te verrichten naar verschillen tussen geschikt verklaarde militairen. Dit betekent dat onderzoek naar de prognostische waarde van beide keuringssystemen zal plaatsvinden. Hierdoor zullen echter zowel sensitiviteit als specificiteit onbekend blijven.

Na het maken van deze ketuze om zowel de reproduceerbaarheid als de prognostische warde van beide keuringssystemen onderling te vergelijken moet vervolgens worden nagegaan bij welke populatie onderzoek moet plaatsvinden, en met welke metingen dat onderzoek moet worden uitgevoerd, waarna moet worden nagegaan met welke determinanten verder rekening moet worden gehouden. 


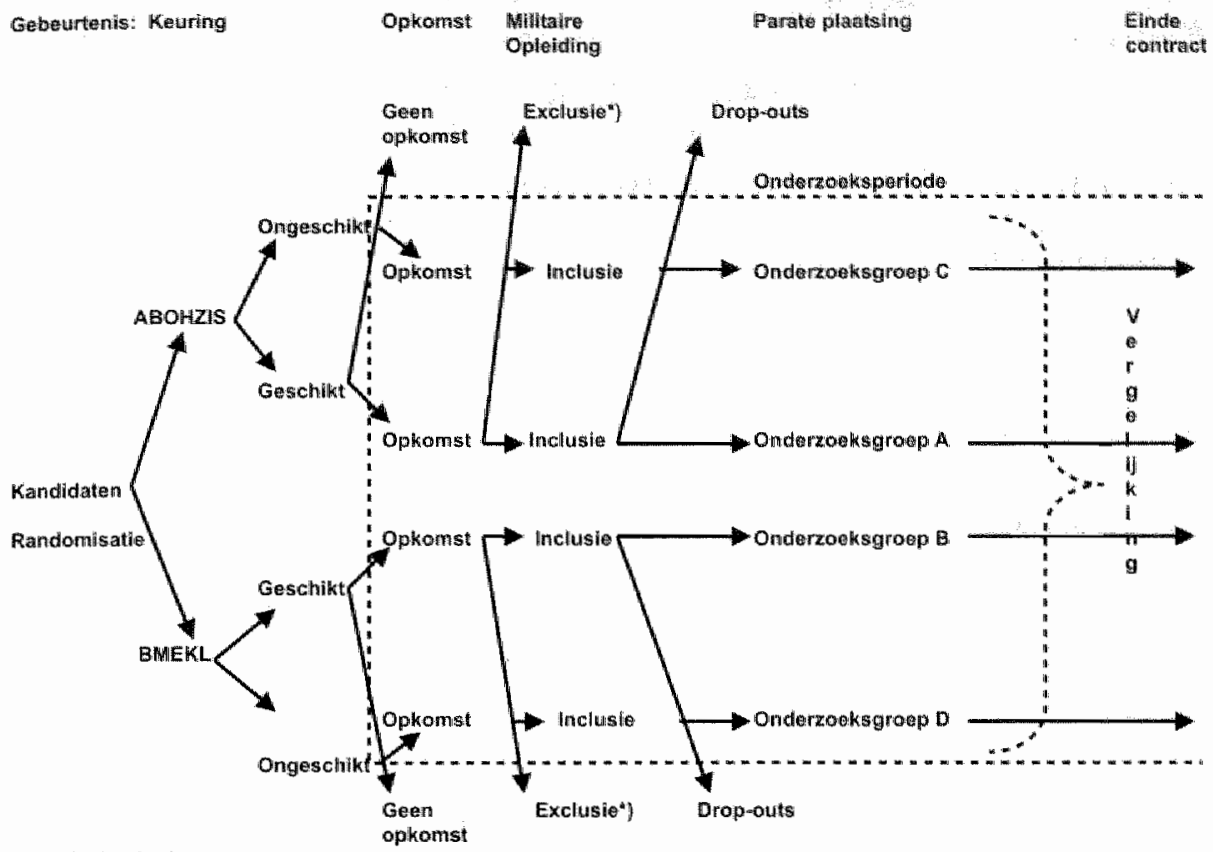

") exclustecriteria

Figuur 3: De ideale onderzoeksopzet voor de bepalling van de voorspellende waarde.

Alle kandidaten, geschikt zowel als ongeschikt verklatrd, worden na opkonst tot het einde van de arbeidsovereenkomst gewolgd.

\section{Kenze van de populatie}

De basispopulatie wordt gevormd door gegadigden voor een aanstelling bij de KL als militair ambtenaar.

Naast grotendeels jonge gegadigden afkomstig uit de civiele sector die een overeenkomst var tijdelijke aard (in de regel $2 \frac{1}{2}$ jaar; "militairen BBT"4) krijgen, vinden aanstellingskeuringen in mindere mate ook bij reeds actief dienend militair personeel plaats dat een overeenkomst van ombepaalde tijd krijgt aangeboden ("militairen BOT" ${ }^{\text {") }}$. Een militair komt pas in aanmerking voor een BOT-arbeidsovereenkomst na succesvol uitdienen van een BBT-overeenkomst. Beide groepen verschillen derhalve in ervaring. Daarnaast is er een leeftijdsverschil tussen beide groepen, verloopt de militaire opleiding anders, de positionering in de hiërarchie is verschillend en de fysieke belasting kan uiteen lopen. Om die redenen wordt de populatie beperkt tot de groep der militairen BBT. 
Met welke metingen moet het onderzoek worden witgevoerd?

Voor het onderzoek naar de reproduceerbaarheid van keuringsuitslagen, ongeacht of dit aanstellingskeuringen dan wel pensioenkeuringen betreft, geldt de keuringsuitslag vanzelfsprekend als de te meten effectvariabele. Voor het onderzoek naar de voorspellende waarde ligt dit ingewikkelder.

In paragraf 1.3.2. is aandacht besteed an onderzoek dat reeds was verricht naar de kwaliteit van aanstellingskeuringen $[20,23]$. Hieruit kwam een aantal aandachtspunten naar voren, dat van nut zou zijn bij verder onderzoek, zoals vermeld in paragraf 1.3.2. Naast een aantal bemerkingen van meer algemene strekking waren daaronder tevens bemerkingen die richting geven aan de te gebruiken effectvariabelen.

Een eerste opmerking daarover luidde dat tot op heden alleen de relatie tussen keuring en uitvall was onderzocht. Het in mindere mate voldoen aan de gestelde (keurings-)eisen behoeft niet altijd tot uitval op grond van beroepsziekten of arbeidsongeschiktheid te leiden. Er zijn ook andere uitingen van het minder aan de gestelde eisen voldoen denkbaar. De vraag is vervolgens hoe dit voor militairen te operationaliseren.

Voor militairen wordt inzetbaarheid als het belangrijkste product beschouwd. Dit begrip is voor deze studie geoperationaliseerd als het aantal dagen tijdens de onderzoeksperiode waarin geen sprake was van verminderde inzetbaarheid door ziekteverzuim of andere vormen van arbeidsverzuim. Door deze definitie kon het netto aantal dagen worden vastgesteld, dat deze militair theoretisch operationeel had kunnen worden ingezet. Weliswar is in paragraaf 1.3.2 reeds gesteld dat verzuim een multifactoriële effectparameter [47] is, onder te verdelen in persoonsgebonden, bedrijfsgebonden en matschappelijke oorzaken, maar omwille van de volgende argumenten is deze effectvariabele desalniettemin bruikbaar voor deze studie:

- het geeft de inzetbaarheid in mat en getal weer;

- voorafgande aan de tewerkstelling vindt achtereenvolgens administratieve, psychologische en fysieke selectie plats, waardoor diverse persoonsgebonden en maatschappelijke factoren worden uitgesloten;

- er vindt cen aanstellingskeuring plaats waarbij eveneens cen aantal persoonsgebonden faccoren worden uitgesloten;

- men wordt binnen een enkele organisatie tewerkgesteld, zodat hooguit minimale verschillen in bedrijfsgebonden factoren resteren;

- onder dé voorafgaande aan de studie onderkende mogelijke confounders (zie paragraaf 1.6.2) bevindt zich een aantal persoonsgebonden en bedrijfsgebonden factoren waarop bij gevonden verschil tussen studiegroepen kan worden gecorrigeerd. 
Een tweede opmerking was dat als artsenbezoek ook een rol by uitval speelt, het zinvol is om bij verder onderzoek ook daaraan aandacht te besteden. Volgens het onderzoek van Carbone [45] zou de hoeveellheid spreekurcontacten omgekeerd evenredig zijn met de inzetbaarheid. Binnen de $\mathrm{KL}$ plaatsgevonden spreekuurcontacten zouden eveneens kunnen worden geteld, maar daarnaast is er de mogelijkheid dat militairen (buiten de diensturen om) ook extern geneeskundige verzorging behoeven. Van die vorm van verzorging kan het precieze aantal contacten niet worden nagegaan, maar de erbij gedeclareerde kosten worden central bijgehouden. Om die reden is de medische consumptie die gedurende de onderzoeksperiode heeft plaatsgevonden als tweede effectrariabele gehanteerd.

Een derde opmerking was dat in geen enkel Nederlands onderzoek de beleving of motivatie van de betrokken werknemers is meegenomen, ondanks het feit dat de invloed van die beleving bekend was. Het gebruik van bijvoorbeeld een periodieke vragenlijst zou op grond hiervan een toegevoegde waarde kunnen hebben bij verder onderzoek.

Samenvattend blijkt uit deze paragraf dat onderzoek zal worden verricht naar het aantal dagen dat de onderzoeksgroep operationeel inzetbaar is geweest, evenals naar de medische consumptie gedurende de onderzoeksperiode. Daarnaast zal gebruik worden gemaakt van een vragenlijst. Voor het operationaljseren van de onderzoeksvragen resteert nu nog om na te gaan onder welke omstandigheden het onderzoek moet worden verricht.

\section{Determinanten}

Welke factoren kunnen van invloed op de resultaten zijn? Zoals onderaan paragraaf 1.4.1. is uiteengezet omvat het nieuwe BMEKL-keuringssysteem het complete scala an taken met inbegrip van operationele inzet. Een belangrijk onderscheid tussen beide keuringssystemen is in theorie dat het voormalige ABOHZIS-systeem geen rekening met deze vorm van inzet hield en het nieuwe BMEKL-systeem nu juist wel. Het complete scala an taken met inbegrip van operationele inzet komt echter pas tot volle uiting onder operationele omstandigheden. Weliswaar wordt de militair door middel van training en opleiding ook onder niet-operationele omstandigheden op operationeel optreden voorbereid, maar behoudens die operationele omstandigheden wordt een specifieke functie vervuld. Die (vredes-)functie zelf vertoont sons sterke overeenkomsten met civiele functies. Bovendien kunnen niet alle aspecten vooraf worden getraind, zoals bijwoorbeeld het ondergaan van hoge temperaturen in een uitzendgebied. Er bestaat derhalve een onderscheid in belasting tussen het optreden onder niet-operationele omstandigheden (lichter, minder breed scala aan taken, bekende omstandigheden) en het optreden onder operati- 
onele omstandigheden (zwaarder, breed scala aan taken, geheel andere omstandigheden).

Of en in hoeverre een aangenomen militair daadwerkelijk wordt uitgezonden, wordt echter niet door middel van de keuring bepaald, maar is afhankelijk van andere factoren, zoals of de betreffende eenheid aan de beurt is voor uitzendingen. Dit betekent dat bij het onderzoek rekening moet worden gehouden met het gegeven of de militair al dan niet operationeel wordt ingezet voor een buitenlandse missie.

Daarnaast kunnen ook die uitkomstvariabelen als determinanten worden beschouwd, waarvan bekend was of waarvan niet kon worden uitgesloten dat zij de inzetbararheid en/of medische consumptie mogelijk beinnvloeden: de locatie van de initiële militaire opleiding (er bestonden verschillen in zwaarte en duur), of men een gevechtsfunctie of een gevechtsondersteunende functie vervult, het onderdeel en de functie war men na de opleiding wordt geplaatst.

Zoals uit paragraaf 1.3.2 blijkt, kan ook aan de eigen beleving van omstandigheden en gezondheid invloed worden toegekend. Hierop wordt in paragraaf 1.6.2. nader ingegaan.

\subsubsection{Vraagstelling voor dit onderzoek}

Om, bij het ontbreken van een gouden standaard, de kwaliteit van beide keuringssystemen onderling te vergelijken zal onderzoek worden verricht naar zowel de reproduceerbaarheid als de prognostische waarde van beide systemen. De reproduceerbaarheid van beide keuringssystemen wordt zowel bij de aanstellingskeuring als bij de pensioenkeuring vergeleken. Daarbij wordt de keuringsuitslag als effectvariabele gehanteerd.

Door middel van de prognostische waarde wordt onderzocht of er associaties bestaan tussen (ến van) beide keuringssystemen en de afhankelijke variabelen dagen inzetbaarheid en medische consumptie, met de eigen beleving van werk en gezondheid als secundaire uitkomstmaat. Dit onderzoek vindt plaats bij militairen BBT, waarbij onderscheid moet worden gemaakt tussen degenen die wel, respectievelijk niet operationeel worden ingezet.

Bovenstaande samenvatting van de operationalisering leidt tot de volgende onderzoeksvragen:

1. Voldoet de reproduceerbaarheid van het nieuwe keuringssysteem bij de pensioenkeuring aan de normering die gebruikelijk is voor screeningstesten'?

6. Volgens Bouter en Vam Dongen [1] suggereren gepubliceerde onderzoeksgegevens dat een kappa tursen de 0,40 en 0,75 voor diagnostische testen in de kliniek gebrukelijk is. 
2. Hoe verhoudt zich de mate van overeenstemming tussen beide keuringsystemen bij de aanstellingskeuring?

3. Is er een verschil in prognostische waarde tussen beide keuringssystemen ten aanzien van de geschikt verklaarde militairen $B B T$ op het gebied van de dagen inzetbaarheid en/of de genoten medische consumptie?

4. Indien een verschil in prognostische waarde tussen beide keuringsystemen wordt gevonden, kan het mechanisme darvan worden verklard door analyse van de determinanten persoonskenmerken, de eigen beleving van gezondheid, inzetbantheid en operationele inzet?

5. Bestaat er ook een verschil in prognostische waarde tussen beide keuringssystemen ten aanzien van uitshitend de uitgezonden militairen en zo ja, kan dat worden verklard door analyse van de determinanten persoonskenmerken, het beleven van de eigen gezondheid, de eigen beleving van gezondheid en inzetbarheid?

\subsection{Materiaal en methoden}

\subsubsection{Populatie}

\section{Groepsgrootte}

Ten aanzien wan de groepsgrootte moest rekening worden gehouden met mogelijke uitwal. Bekende redenen voor uitval waren (en zijn):

- Uitval door psychologische selectie. Deze uitval bedroeg ongeveer $30 \%$ van de gegadigden.

- Uitval door afkeuring en fysieke selectie van de overgebleven kandidaten. Deze uitval was niet exact te voorspellen omdat in de gekozen onderzoeksperiode een nieuw systeem voor fysieke selectie werd ingevoerd en het Instituut Keuringen en Selectic (IKS) geen concrete informatic over afkeuringen kon verschaffen. Desgevraagd schatten de uitslaggevend seniorbedrijtsartsen van het IKS deze utval globaal in op $20-30 \%$ van de na de psychologische selectie overgebleven kandidaten.

- Uirval door het veiligheidsonderzoek (militair personeel wordt voorafgande de formele aanstelling door de Militaire Inlichtingen en Veiligheidsdienst gescreend op veiligheidsaspecten). De groepsgrootte hiervan was onbekend, maar vooraf werd als gering ingeschat.

- Uitval in de eerste opleidingsweken. Intern onderzoek toonde aan dat in de jaren 1997 (zowel als in 1998 en 1999) sprake was van een niet-nedische uitval van tussen de 20 en $30 \%$ van de geschikt bevonden kandidaten.

Naar inschatting van de witslaggevend artsen werden in 1998 maandelijks tussen de 300 en 500 kandidaten medisch gekeurd. Om twee groepen van voldoende 
grootte te kunnen formeren zou een periode van 6 tot 8 weken volstaan. Om orinodige variatic uit te sluiten, diende sprake te zijn van een zo kort mogelijke, maar in elk geval aaneengesloten periode.

\section{Exclusiecriteria}

Behoudens het onderzoek te beperken tot militairen met een overeenkomst van bepalde tijd ("BBT"), diende tevens met de volgende feiten rekening te worden gehouden:

- Kandidaten bestemd voor de Nationale Reserve (Natres) worden administratief ook als gewone KL-gegadigde beschouwd, terwijl hun taakstelling niet vergelijkbaar is met die van de gewone KL-militair (geen operationele inzet buiten de landsgrenzen en in beginsel alleen in de weekeinden actief). Om deze redenen dienden deze kandidaten te worden uitgesloten.

- Er bestaan functies binnen het bestand aan KL-militairen, waarvan het risicoprofiel teveel afwijkt van het in de Wijziging van de Wet op de Medische Keuringen over militair ambtenaren geformuleerde risicoprofiel, zoals militaire muzikanten en geestelijk verzorgers. Ook bij deze gegadigden moest uitsluiting plaatsvinden.

- Bekend was dat tijdens de initiële militaire opleiding of AMO een forse uitval ontstaat - gedurende de opleidingsperiode kan de rekruut de verbintenis eenzijdig opzeggen. Wellicht zou hierin qua omvang al een onderscheid te signaleren zijn bij een vergelijking tussen twee onderzoeksgroepen (alhoewel tot dan toe intern onderzoek had uitgewezen dat meer dan $95 \%$ van de bij voortijdig vertrek opgegeven redenen van niet-medische aard zijn). Het probleem is dat deze "drop-outs" vertrekken tussen de dag na opkomst en de eerste 12 weken. Hierdoor zou bij een vergelijking van diegenen die (veel langer) bij de KL blijven (en van de opleidingssituatie overgaan naar een situatie waarin zij concrete werkzaamheden moeten uitvoeren) een sterke informatie-bias optreden.

- Het moment van de anstellingskeuring behoefde niet maatgevend te zijn voor het moment van opkomst en tewerkstelling. Ten tajde van de onderzoeksopzet was niet bekend hoeveel tijd er lag tussen het moment van keuren en het moment van dadwerkelijke opkomst. Het was de bedoeling om alle personen van de onderzoeksgroep (of groepen) gedurende dezelfde onderzoeksperiode te volgen.

- Omdat het hierboven genoemde delay ten tijde van de onderzoeksopzet onbekend was, viel evenmin uit te sluiten dat er ook nog rekruten zouden zijn die ondanks hun geschiktheid niet op zouden komen, bijvoorbeeld omdat ze in de tussenliggende periode een andere (civiele) functie hadden aanvaard. 


\section{Onderzoeksperiode}

Het nieuwe BMEKL-keuringssysteem zou per 1 november 1998 worden ingevoerd. Om die reden werd voordien bijscholing in het gebruk van het nieuwe systeem voor de keurend artsen georganiseend. Hierdoor werd het mogelijk om woorafgaande aan de invoering van dit nieuwe systeem tijdelijk beide keuringssystemen tegelijkertijd te gebruken.

Bekend was reeds dat er een verschil in beweegredenen van gegadigden bestat tussen diegenen die zich aansluitend an de afloop van het schooljaar (en/of in de daaropvolgende zomervakantie) aanmelden en diegenen die zich gedurende de rest van het jaar aanmelden. De laatste groep mist de naturulyjke aansluiting, hierdoor zijn de beweegredenen om zich tot de KL te wenden meer pluriform van aard dan van de eerste groep. In de zomervakantie zelf treedt mogelijk selectiebias op door vakantie van zowel de gegadigden als de keurend artsen. Hierdoor werd de ideale onderzoeksperiode gedefinieerd als zijnde de maanden september en oktober 1998.

Omdat onder de exclusiecriteria is vermeld dat het delay tussen keuring en opkomst niet bekend was, werd de onderzoeksperiode vastgesteld als de periode warin de meeste kandidaten na hun militaire opleiding op functie worden geplatst. Uiteindelijk bleek dit de periode van 1 juni 1999 tot 1 juni 2001 te zijn.

\subsubsection{Procedure}

\section{Reproduceerbaaheid}

Omdat het keuringssysteem voor zowel de anstellingskewring als de pensioenkeuring zou worden gebruikt moest reproduceerbatheidonderzoek voor beide processen plaatsvinden.

In de ideale situatie wordt de reproduceerbarheid beoordeeld door de kandidaten achtereenvolgens door twee verschillende artsen te laten keuren (inter-waarnemers variatie), of na verloop van tijd opnieuw door dezelfde arts (intra-warnemers variatie).

Zelf aan deze ideale opzet kleven nadelen, zoals rechtspositionele problemen (aannemen of afkeuren bij discongruente uitslagen?), eventuele invloed uitgeoefend door de onderzoekers (op gedrag van de keurling of op elkaars beslissing), dan wel het herkennen van de keurling bij een tweede beoordeling door dezelfde arts.

Voor de beoordeling van de reproduceerbarheid in dit onderzoek is ervoor gekozen om dat aan de hand van de beoordeling van dossiers te laten bepalen. Alhoewel hieraan ook nadelen zijn verbonden (zoals de kans op informatie-bias), is dergelijk onderzoek al vaker verricht, hetgeen de aanvardbaarheid ervan verhoogt. 
Het bepalen van de mate wan overeenkonst tussen bedrijfsartsen bij de aanstellingsketring kon qua onderzoekspopulatie worden gecombineerd met een prospectief onderzoek, omdat dit laatste bij de aanstellingskeuring moest beginnen. Hierdoor zou in elk geval voldoende onderzoeksmateriaal ontstaan on de mate van overeenkomst te meten.

Het bepalen van de mate van overeenkonst tussen artsen bij de pensioenkeuring kon beter met behulp van een andere populatie plaatsvinden. Er was geen garantie dat een coliortstudie naar geschikt verklaarde militairen voldoende pensioenkeuringen zou opleveren on tot een aanvardbaar minimum aan dossiers te geraken, nog afgezien van de onbekende tijdsduur die het verzamelen ervan in beslag zou nemen. Onbekend was vooraf immers wanneer militairen eventueel ongeschikt zouden worden of wanneer zij hun claim zouden indienen (rechtspositioneel mag dit op elk moment plaatsvinden, bijvoorbeeld ook eerst na afloop van de verbintenis).

\section{Mogelijke confounders}

Een confounder is een verstorende variabele die de weergave van de relatie tussen centrale determinant en onathankelijke variabele vertekent (bijvoorbeeld roken bij onderzoek naar de relatie tussen allcoholconsumptie en het voorkomen van strottehoofdkanker) [1]. Confounding kan het best worden bestreden door correctie en randomisatie [1]. Met name op grond van de in de internationale literatuur gevonden risicofactoren, alsmede op grond van reeds door anderen verricht intern onderzoek, zijn voorafgaande aan het onderzoek de volgende mogelijke confounders onderscheiden:

- Persoonskenmerken, warvan bekend was of werd aangenomen dat zij de inzetbaarheid en/of medische consumptie beinvloeden: leeftijdsverschillen (op jonge leeftijd geeft een gering leefiijdsverschil al een hogere slagingskans in de militaire opleiding ten gunste van de oudere rekrunt), het geslacht (vrouwen verzuimen meer dan mannen), de gezinssituatie (herkomst uit een compleet gezin is bevorderlijk voor het behalen van de opleiding), rookgewoonten (kunnen tot ziekte leiden), de schoolopleiding (hoe hoger de schoolopleiding des te groter de kans op slagen in de militaire opleiding), herkomst uit een stad dan wel van het platteland (plattelanders behalen vaker hun militaire opleiding).

- Keuringsgegevens, waarvan bekend was of werd aangenomen dat zij de inzetbaarheid en/of medische consumptie beïnloeden zoals het wel of niet ter keuring vaststellen van medische bijzonderheden door de keurend arts (met een bijzonderheid mogelijk grotere kans op uitval), de aard van die medische bijzonderlueden, de vastgestelde mate van fysieke opleidbaarheid. (des te hoger, des te geringer de kans op blessures), het vetpercentage (hoe lager des te hoger de conditie), de keurend arts zelf. 
- Uitkomstvariabelen, waarvan bekend was of waarvan het vermoeden bestond dat zij de inzetbaarheid en/of medische consumptie kunnen beinvloedden: de locatie van de initiële militaire opleiding (er zijn verschillen in zwaarte en dutr), of men een gevechtsfunctie of een gevechtsondersteunende functie vervult, het onderdeel en de functie waar men na de opleiding wordt geplaatst, of men al dan niet wordt uitgezonden.

Deze gegevens konden in beide onderzoeksgroepen van invloed zijn, er moest wellicht voor worden gecorrigeerd; derhalve dienden deze gegevens te worden verzameld en bijgehouden.

\section{Randomisatie}

Om het verschil te meten tussen geschikt verklaarde BBT-militairen van beide keuringssystemen moesten twee onderzoekgroepen worden geformeerd. Randomisatie kon in theorie weliswaar op verschillende manieren plaatsvinden, maar de keuzemogelijkheden werden in de praktijk beperkt. Zo zou het dagelijks aanbieden van aselect (bijvoorbeeld op grond van een lijst met aselecte getallen' in de twee keuringssystemen ingedeelde kandidaten aan elke keurend arts tot diverse problemen kunnen leiden: het gevaar verstrikt te raken in verschillende diagnostische classificatieschema's [1], expectation bias [1], de hoge moeilijkheidsgraad van controle door derden op de correcte uitvoering en motivatieproblemen bij de keurend arts. In de voorbereiding tot dit onderzoek leidde dit tot de volgende wijze van randomisatie: om de samenstelling van de twee studiegroepen vergelijkbaar te maken zou per week van keuringssysteem worden gewisseld. Dit leidde tot de in figuur 4 weergegeven onderzoeksopzet. Eventuele bias kon nu op de volgende manieren worden beperkt. In de eerste plaats wist elke keurend arts op welke wijze hij / zij die week geacht werd te keuren: één periode, lang genoeg om zicl op het betreffende keuringssysteem te kunnen focussen. Voorts kon de uitslaggevend seniorbedrijfsarts (die de keuringsdossiers verzamelde) relatief eenvoudig controleren of de juiste werkwijze werd gehanteerd en zo nodig corrigerend optreden. Bovendien waren alle dossiers gedateerd en kon de onderzoeker na afloop zelf ook controleren of de juiste werkwijze was gehanteerd.

In hoofdstuk 4 wordt onder de paragraaf "Achtergrondinformatie" gedetailleerd ingegaan op de aanstellingsprocedure. Hier wordt volstaan met op te merken dat de volgorde warin kandidaten voor de aanstellingskeuring worden opgeroepen willekeurig is, waardoor het begrip randomisatie mag worden gebruikt voor de hierboven geschetste procedure.

\section{Informatiebronnen}

Voor het uitvoeren van dit onderzoek werd het radplegen van de volgende gegevens noodzakelijk geacht: de dossiers van de aanstellingskeuring, exitinter- 
views afgemomen bij dienstverlaters, centraal beheerde (over-) platsingsgegewens, het central gecontroleerde en beheerde verzumregistratiesysteem, gegevens afkomstig van de pensioenkeuring, de interne geneeskundige verrichtingenadministratic zoals opgemaakt door de militaire zorgverleners en de door de onderzoeksgroep bij de ziektekostenverzekeräur ingediende declaraties van civiele zorgverleners. Het verlenen van schriftelijke toestemming door de betreffende kandidaat voor het mogen verzamelen van bovenstaande gegewens heeft tijdens de keuring plaatsgevonden. De kandidaten waren niet op de hoogte van het onderzoek of het feit dat zij gerandomiseerd gekeurd werden. Alle tot nu toe beschreven gegevens waren afkomstig van derden en verschaften informatie over de te volgen militair zonder dat deze zelf om een mening werd gevraagd. Als anvulling hierop is ook aandacht besteed aan de eigen beleving van de onderzoekspersonen; bovendien zouden deze gegevens ook nog als controle op de overige informatie kunnen dienen.

De gehanteerde vragenlijst (tabel 8) was gebaseerd op de "groene vragenlijst" (VAG) van het Periodiek Arbeidgezondheidkundig Onderzoek [54] (PAGO) en vrijwel op dezelffle wijze geclusterd $[55,56]$. Die groene vragenlijst bestond zelf uit twee onderdelen: het onderdeel gezondheidsbeleven (in deze vragenlijst clusters $3,4,5$ en 6) en het onderdeel werkbeleven (in deze vragenlijst clusters 8 tot en met 13). Hieraan waren voor deze vragenlijst 8 clusters toegevoegd: twee ter controle van elders verkregen gegevens (clusters $1 \mathrm{en} 2$ ), één voor het beoordelen van de medische consumptie (cluster 7), en vier clusters om de uit het FIS ontleende BMEKL-vragen in te plaatsen (14 tot en met 17). Het achtste nieuwe cluster -18 - bevatte de omzetting van de specifieke militaire beoordelingspunten naar vragen. Alle vragen vanaf cluster 3 waren dichotoom. Bij de vragen uit de clusters 3 tot en met 7 werd specifiek naar de situatie van het laatste half jaar gevraagd.

Vanaf het begin van de onderzoeksperiode ontving de kandidaat deze vragenlijst halfjaarlijks, in totaal vijf maal. Positieve reacties telden voor 1 punt, negatieve voor 0 punten.

Vijf maal achtereen ontwing de kandidaat gedurende de onderzoeksperiode halfjaarlijks de hierboven vermelde vragenlijst op het verblijfadres met als doel om na te gaan of er verschillen tussen de twee studiegroepen zouden optreden in de beantwoording van de verschillende clusters.

\section{Effecruatiabelen}

Voor deze studie is de inzetbaarheid geoperationaliseerd als het aantal dagen rijdens de onderzoeksperiode warin geen sprake was wan verminderde inzetbatheid door ziekteverzum of andere vormen van arbeidsverzuim. Omdat in 


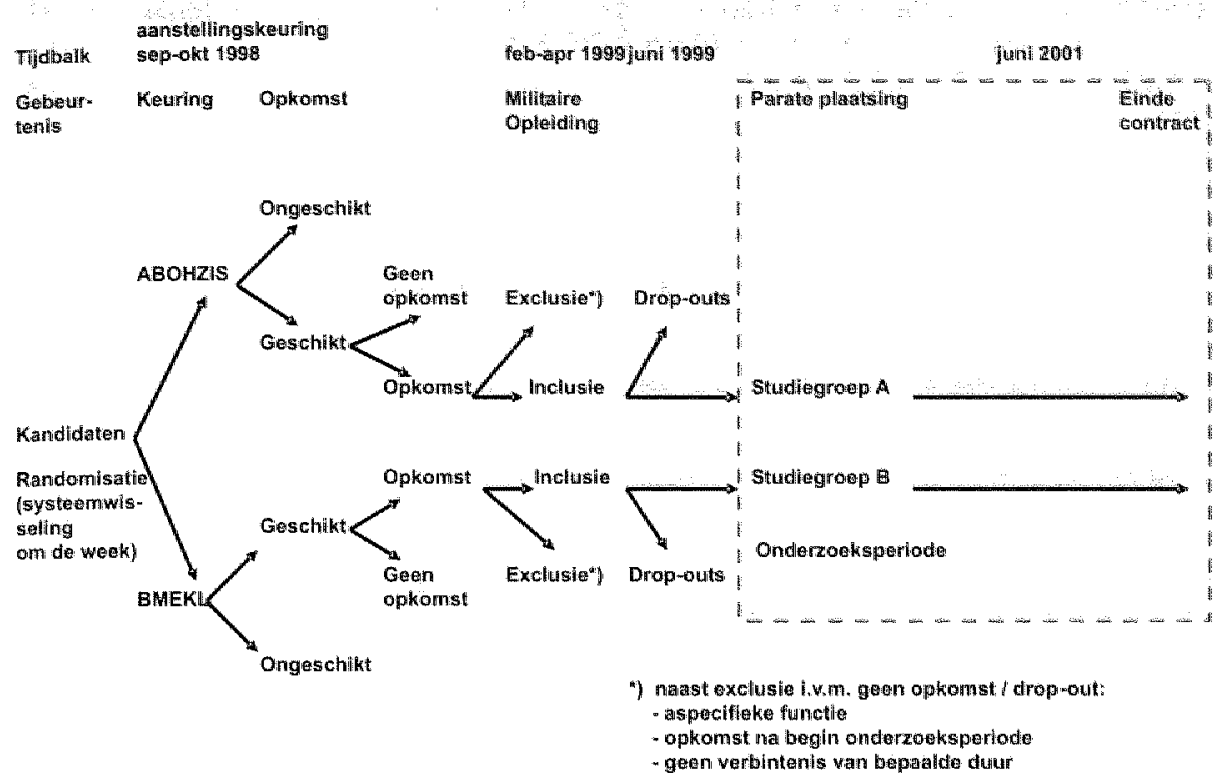

Figutur 4: De onderzoeksopzet van de gerandomiseerde gecontroleerde studie.

Na gerandomiseerd te zijn gekeurd worden de geschikt werklaarde kandidaten na opkomst gedurende de periode wan paratstelling (twee jaar) tot het einde van de arbeidsovereenkonst gevolgd.

de onderzoeksperiode een schrikkeljaar zat, bedroeg het maximale antal dagen inzetbaarheid 731 kalenderdagen.

Inzake de medische consumptie is het volgende van belang. De krijgsmacht, respectievelijk de KL, beschikt over een eigen eerstelijns geneeskundig zorgsys-teem (huisartsenzorg) en voorziet voor de belangrijkste klinisch specialismen ook in de tweede lijns gezondheidszorg. Die eerstelijns zorg geldt echter in eigen land slechts tijdens kantooruren. Tijdens operationele inzet en bij plaatsing in Duitsland wordt 24 uur per dag eerstelijns gezondheidszorg verstrekt. Buiten kantooruren kan een militair zich tot een civiele (eerste- of tweedelijns) zorgverlener wenden; hiervoor is de nilitair verzekerd. De verrichtingen van de eigen eerste lijn worden in een centrale database vergaard. Alle tweedelijns verrichtingen, alsmede extern geraadpleegde eerstelijns verrichtingen, worden door de ziektekostenverzekeraar vergoed na declaratie. Om een volledig overzicht te verkrijgen over de total gemaakte medische kosten moeten zowel de ziektekostenverzekeraar als de database worden geraadpleegd. De medische eerstelijns consumptie is berekend door alle eerstelijns consulten te rekenen naar het gemiddeld over de onderzoeksperiode geldende CTG-tarief $(€ 17,92)$. De overige gemaakte en gedeclareerde ziektekosten zijn -inclusief in het eigen 
Tabel 8. De clusterindeling van de gebruikte vragenljyst. De clusters 1 en 2 bestaan voornamelijk uit niet-dichotome controdevragen en vallen buiten verder onderzoek.

\begin{tabular}{|c|c|c|}
\hline Cluster & Aantal vragen & Herkonst \\
\hline Controleviagen & 8 & onderzoeker \\
\hline Controlevragen & 9 & onderzoeker \\
\hline Algemerie gezondtheid & 4 & PAGO-gezondheid \\
\hline Bewegingsappartat & 9 & PAGO-gezondheid \\
\hline $\mathrm{KMO}$ & 3 & PAGO-gezondheid \\
\hline Stress & 4 & PAGO-gezondheid \\
\hline Medische consumptie & 9 & onderzoeker \\
\hline Talakinhoud & 5 & PAGO-werk \\
\hline Werkorganisatic & 5 & PAGO-werk \\
\hline Samenwerking & 5 & PAGO-werk \\
\hline Toekomsiperspectief & 5 & PAGO-werk \\
\hline Duidellijkheirl & 3 & PAGO-werk \\
\hline Privé & 3 & PAGO-werk \\
\hline FIS-bewegingsapparaat: & 16 & onderzoeker \\
\hline Fysisch-chemisch, buiten & 8 & onderzoeker \\
\hline Zintuigen & 3 & onderzoeker \\
\hline FIS-psychisch & 14. & onderzoeker \\
\hline Militaire beoordelingspunten & 15 & onderzoeker \\
\hline
\end{tabular}

zorgsysteem gemaakte tweedelijns kosten - bij de ziektekostenverzekeraar opgevraagd.

\subsection{Verdere uitwerking van het onderzoek}

Nadere uitwerking vindt plats in de volgende hoofdstukken Allereerst wordt, zoals aangekondigd in paragraaf 1.2., een systematische waarneming weergegeven in hoofdstuk 2. Daarin wordt het reproduceerbaarheidonderzoek naar de kwaliteit van het ABOHZIS-systeem bij periodieke keuringen weergegeven dat in 1996 is verricht na kennis te hebben genomen van het werk van De Kort en Post-Uiterweer $[2,13]$ (figuur 5).

Hierna worden alle hierboven vermelde vragen achtereenvolgens in een apart hoofdstuk ( 3 tot en met 7) behandeld. In figuur 6 wordt een overzicht van de darin gehanteerde werkwijzen weergegeven, waarbij ook de verschillende hoofdstukken staan vermeld. 


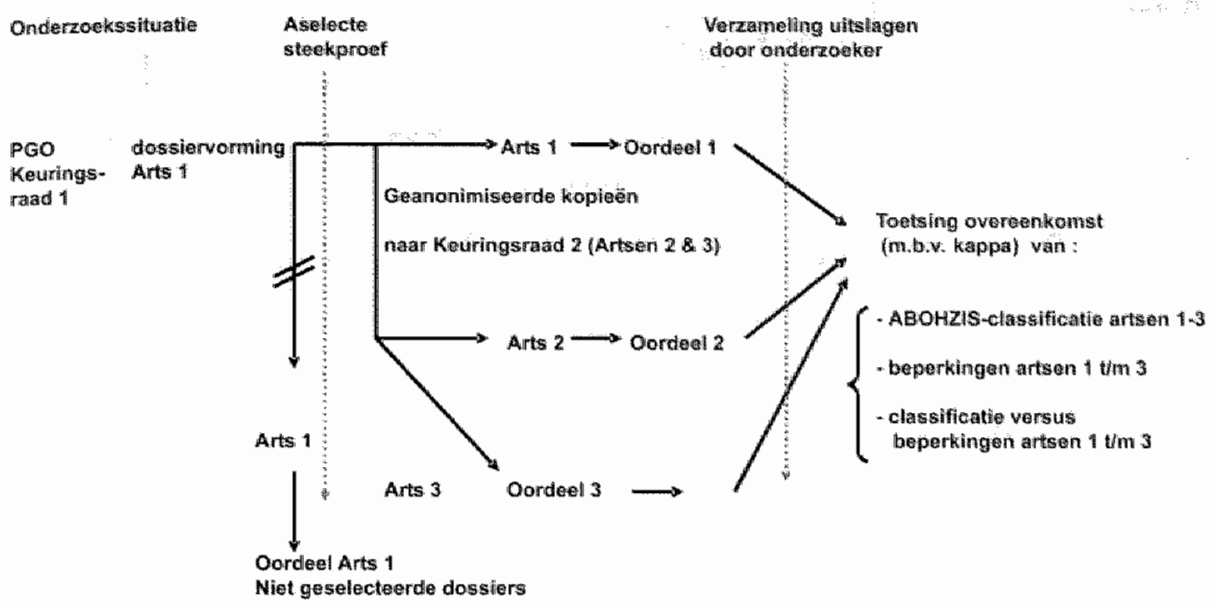

Figuur 5: De onderzoeksopzet van hoofdstuk 2

24 asellect gekozen keuringsdossiers, afkomatig van één keuringstadd, worden geanonimisered aan twee artsen van de andere keuringsrad angeboden met het verzoek on zowel de

ABOHZIS-classificatie als de beperkingen wast te stellen, warna het resultant met de origincle untslag wordt wergeleken met behulp van de kappa en PD.
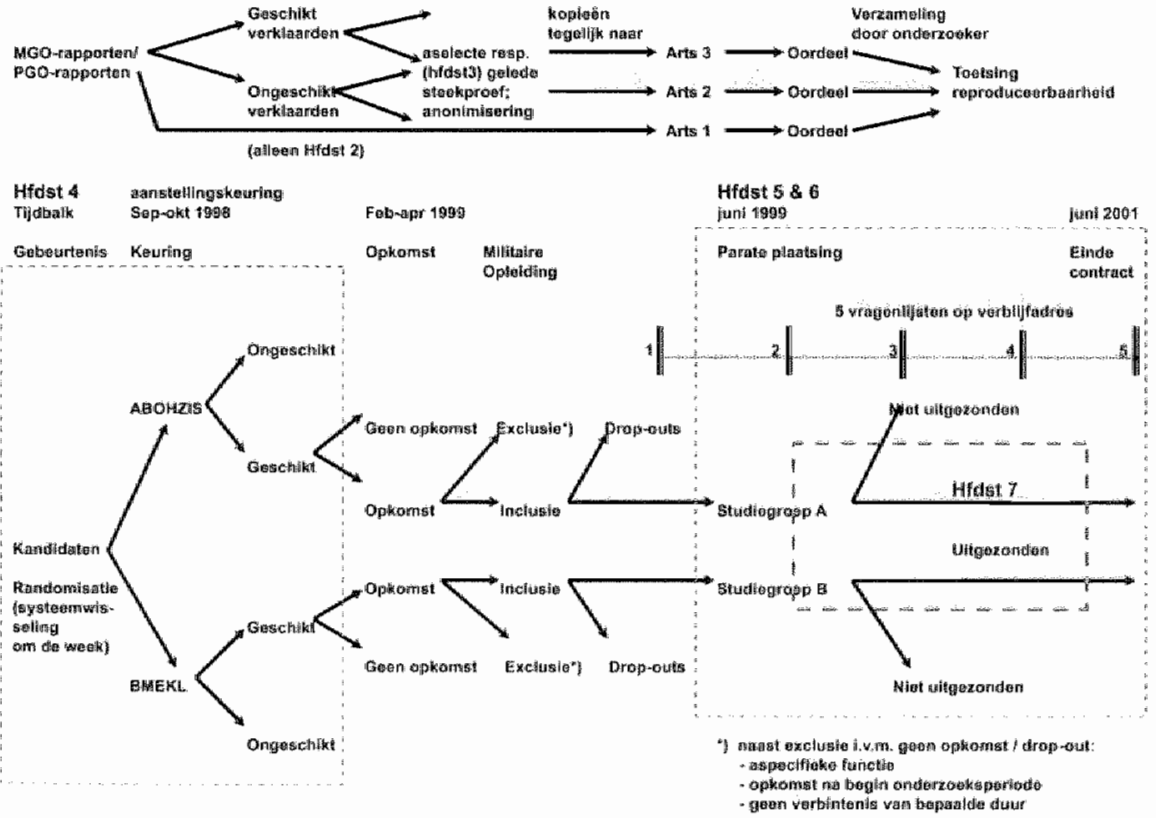

Figuur 6:Het overzicht van de onderzocken uit dit proefschrife en de darbij behorende hoofdetukken. In de hoofdstukken 2 en 3 wordt de reproduceerbaarheid van het periodiek geneeskindig onderzoek, respectievelijk de pensioenkeuring onderzocht, analoog aan Figuur 5. Hoofdstuk 4 bevat soortgelijk onderzoek voor wat betreft de aanstellingskeuringen van dezelfde gerandomisecrde, gecontroleerds studie, van wie de twee studiegroepen in de hoofdstukken 5 en 6 gedurende hun jlatsing op functic worden gevolgd om de voorspellende waande tussen beide keuringsystennen te kunnen wergelijken. 


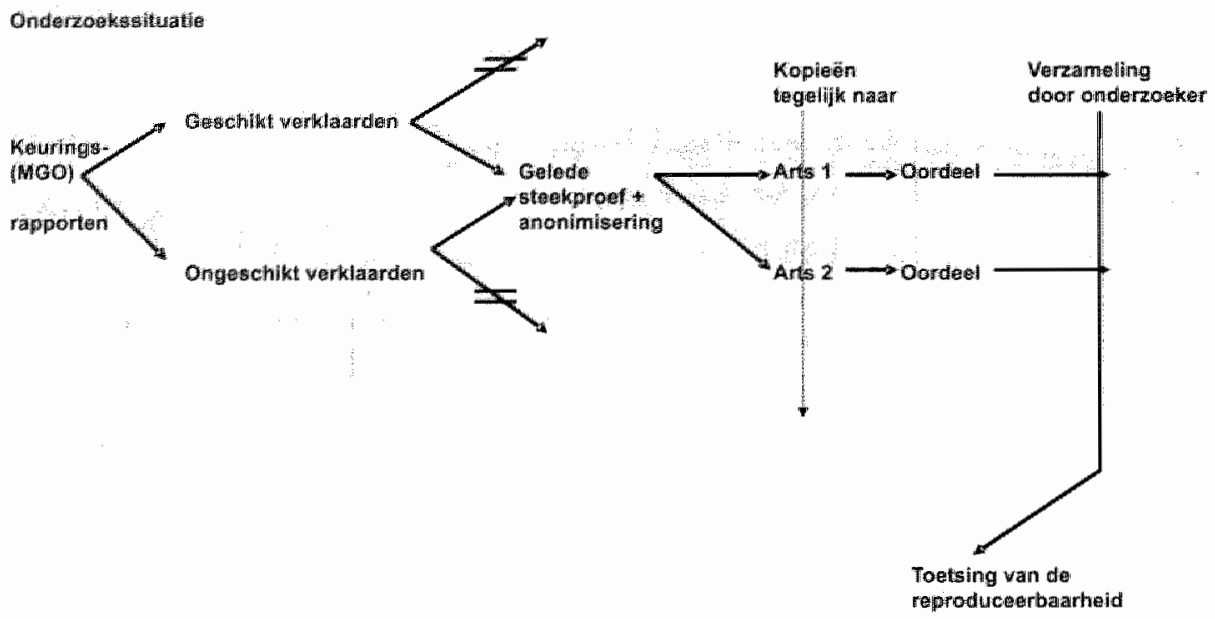

Figuur 7: De onderzoeksopzet van hoofdstuk 3.

In hoofdktuk 3 wordt de reproduceerbaarheid van de pensioenkeuring onderzocht, analoog aan de wijze warop dat in Figutur 5 woor het periodick geneeskundig onderzoek heeft plaatsgevonden.

\begin{tabular}{|c|c|c|c|}
\hline Thldobalik & Sep-03k 1998 & Fob-apr 1999 & 2000 \\
\hline Gobeurtem & Koturlag & $\begin{array}{l}\text { Vortamelang dosmars } \\
\text { an:atimiseren }\end{array}$ & Toetsen oweregensternem hirng \\
\hline
\end{tabular}

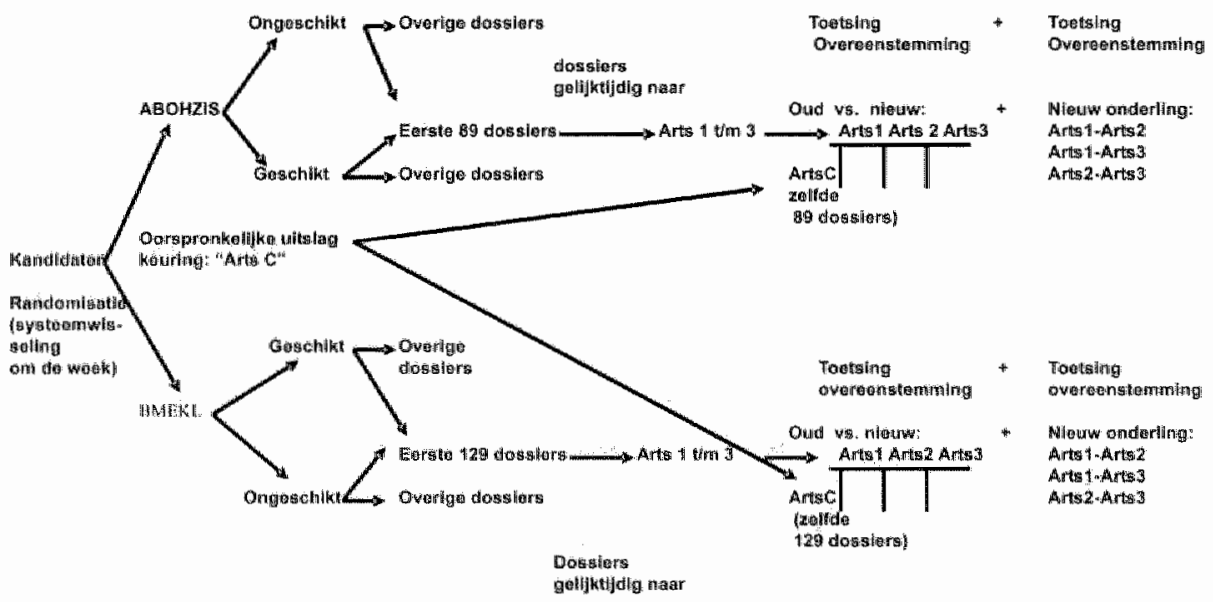

Figuur 8: De onderzocksopzet van hoofdstuk 4 .

Met behulp van dossiers uit de getandomiseerde,gecontrolecede studie wordt de reproduceerbaarheid van beide keuringssystemen wor wat betreft de anstellingskeuring onderzocht. Hierbij worden zowel de nieuwe uitslagen onderling vergeleken ("Nieuw onderling"), als de nieuwe uitslagen met de oorspronkdijke uitslag ("Ond versus nieuw, Arts $\mathrm{C}$ versus de Artsen 1, 2 en 3). 


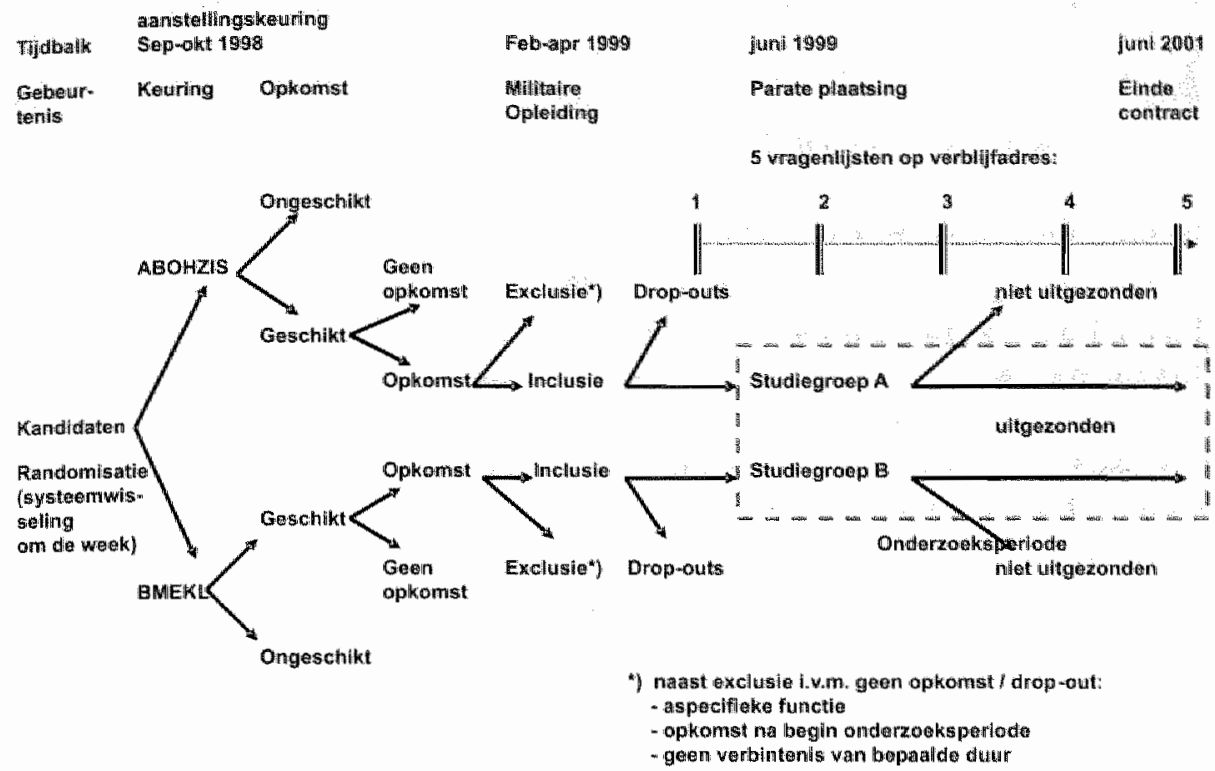

Figuur 9: De onderzoeksopzet voor hoofdstuk 7.

In deze studie worden unitsluitend de uitgezonden militairen, gerandomiseerd gekenrd en in twee studiegroepen verdeeld, gevolgd.

In hoofdstuk 3 wordt het onderzoek naar de reproduceerbaarheid van het nieuwe keuringssysteem tijdens de pensioenkeuring weergegeven conform onderzoeksvraag 1 . In dit onderzoek zijn 30 geanonimiseerde keuringsdossiers, waronder evenveel geschikt als ongeschikt verklaarden, ter beoordeling aan twee seniorbedrijfsartsen voorgelegd, waarna de reproduceerbatheid is berekend (figuur 7).

In hoofdstuk 4 wordt het onderzoek naar de mate van overeenstemming tussen beide keuringssystemen bij de aanstellingskeuring weergegeven (onderzoeksvraag 2). Hiertoe werden 227 keuringsdossiers, afkomstig van beide keuringssystemen, geanonimiseerd. Vervolgens werden deze dossiers opnieuw voorgelegd aan dezelfde drie seniorbedrijfsartsen die in het najaar van 1998 hierover al uitslag hadden gegeven, waarna de reproduceerbaarheid is berekend (figuur 8).

In hoofdstuk 5 wordt de gerandomiseerde, gecontroleerde studie voortvloeiende uit vraag 3 naar de geschikt verklaarde militairen behandeld (figuren 4 en 6). In de periode juni 1999 - juni 2001 werd een groep van 352 militairen BBT gedurende twee jaar gevolgd, nadat zij gerandomiseerd volgens het nieuwe BMEKL - dan wel het oude ABOHZIS-keuringssysteem waren beoordeeld. 
In hoofdstuk 6 wordt het onderzoek, voortvloeiende uit vraag 4 beschreven. In dit hoofdstuk worden analyses gepleegd om het mechanisme, dat achter de gevonden associatie schuilgaat, aan te tonen. Daarbij wordt gebruik gemaakt van een vragenlijst die gedurende de onderzoeksperiode vijf maal an de onderzoekspersonen is voorgelegd (figuren 4 en 6 ).

In hoofdstuk 7 wordt het onderzoek naar aanleiding van vraag 5 weergegeven (figuur 9), Gegeven de vraagstelling wordt in dit hoofdstuk uitsluitend aandacht besteed aan de uitgezonden militairen uit beide studiegroepen, die voor de hoofdstukken 5 en 6 zijn gebruikt. Bij dit onderzoek wordt zowel gebruik gemaakt van dezelfde effectvariabelen als in de hoofdstukken 5 en 6 , als van de van de laatste drie halfjaarlijks toegezonden vragenlijsten, zijnde de periode waarin de uitzendingen plaatsvonden.

Het afsluitende hoofdstuk 8 bevat een nabeschouwing op de verrichte onderzoeken, gevolgd door het beantwoorden van de onderzoeksvragen. Hierna wordt de hypothese getoetst. Vervolgens wordt beoordeeld of en in hoeverre het onderzoek invloed heeft op de theorie, waarna wordt besloten door na te gaan wellk onderzoek resteert op het terrein van (militaire) keuringen.

\section{Geraadpleegde literatuur}

1. Bouter LM, Dongen MCJM van: Epidemiologisch onderzoek, opzet en interpretatie. Bohn, Srafleu en van Loghum. Houten, 1995.

2. Kort WLAM de, Post--Uiterweer HW: Project aanstellingskeuringen dossieronderzoek bij de RBB. Deel II: panelonderzock. Ministerie van Sociale Zaken en Werkgelegenheid, S 53-2, 1991.

3. Rand J de: De historie van het Militair Keuringsreglement en de Lijst wan ziekten en gebreken. "Writhe nummy teturns?" Nederl Mil Geneesk 7" 2002; 55:146-151.

4. Romeyn D: Onze Militai-Geneeskundige Dienst voor honderd jaren en daromtrent. Harlem: De Erven F Bohn, 1913.

5. Banger JD: Het militair geneeskundig onderzoek (de visitatie) in de vorige eeuw. Nederl Mil Gencesk T 1988; 41:167-206.

6. Fouw de: Referax over de methode van Warnecke woor de ontmaskering van dooheids-simulanten. Nederl Mil Geneesk T 1900; 243-244.

7. Quix FH: Voordracht over "Ontmaskering van doofheidssinullanten in verband met eene nieuwe methode van bepaling der gehoorscherpte voot toonthoor en fluisterstem". Nederl Mil. Genecsk T 1903;177-198.

8. Wignan PW: Simulatie en aggravatie van dooheid. Nederl Mil Geneesk T 1935; 24: $127-137$.

9. Spruyt S: Over simulatie. Nedet Mil Geneesk T 1958; 11:1-13.

10. Romeyn D: Over ongeschiktwerklaring en pensioneering van onze mindere militairen. Nederl Mill Geneesk T 1895;159-173.

11. Belloni R: De bepaling van de dienstgeschiktheid. Utrecht, 1985. 
12. Koster $\mathbb{L}$ : Keuringseisen ten anzien van allergische andoenngen voor de malitaire dienst. Nederl Mil Geneesk T 1959;7:173-186.

13. Dijk FJH van; Dormolen $M$ van, Kompier MAl et al: Herwardering nodel belastingbelastbaarheid. TSG, 1990; 68:3-10.

14. Kessel JGFM wan: Consequenties van onjuist kewren. Ned Mil Geneesk T; 1984; 37 : 176-228.

15. Lourijsen ECMP, Kort WLAM de, Dam J: De praktijk wan de medische anstellingskeuring in Nederland. Ministerie van Sociale Zaken en Werkgelegenheid, S 53-3, 1991.

16. Lourijsen ECMP, Hoolboom H, Kort WLAM de: De Medische annstellingskeuring. Een inventarisatie van de mate warin en de wijze watop Nederlandse bedrijen en artsen medische annstellingskeuringen (taten) vernichten. DGA S 53-1,1989.

17. Kort WLAM de:Personnel selection through pre-employment medicals. Amsterdam, 1993.

18. Kort WLAM de, Fransman LG, Dijk FJH van: Pre-employment medical examinations in a large occupational thealth service. Sacnd ] Work Environ \& Health 1991; 17:392-297.

19. Kort WLAM de, Dijk FJH van. Preventive eflectiveness of pre-employment medical assessments. Occupational Environmental Medicine 1997; 54: 1-6.

20. Reulings PGI: Keuren is mensenwerk. Maastricht, 1996.

21. Reulings PGJ, Horst F van der, Crebolder HFJM et al: Her keuringstraject voor dienstplichtigen wan de Koninklijke Landmacht. Neder Mil Geneesk T 1994; 47:201 204.

22. Reulings PGI, Stummans F; Crebolder HFJM et al: Prognostische factoren van het nedisch disfunctioneren tijdens militaire dienst bij de Konirklijke Landmacht. TSG 1995; 73: $505-511$.

23. Reulings PG, Crebolder HFMM, Schouten HIA ot al: Medisch keuren is mensenwerk. Variatie tussen artsen bij de beoordeling van de geschiktheid voor militaire dienst. "TSG 1996 ; 74:213-216.

24. Revlings PG], Schouten HJA, Rethans JJ et all Reproduceerbaarheid van de beoordeling bij dienstpliclatkeuringen. TSG 1996;74:267-271.

25. Raad J de, Reulings PGJ, Schouten HJA: De beperkingen van medische beperkingen. De reproduceerbaarheid wan de beoordeling van de ABOHZIS-classificatie en de medische beperkingen bij periodiek geneeskundig ondierzoek bij de Koninklijke Landmacht. Ned Mil Geneesk T; 1996:49:106-111.

26. Deursen CGL van, Smulders PGW, Bongers PM: Vormt een slechte greondheid exen ziekteverzuimrisico? TSG 1997; 75: 157-164.

27. Otten FW], Smulders PGW, Houtman ILD: Werkstress en ziekteverzum bij jong en oud. TSG $1998 ; 76: 420 \sim 428$.

28. Deursen CGL van, Houtman ILD, Bongers PM: Werk, priwé-situatie, riskante gewoonten en ziekteverzuim: verschillen tussen mannen en vrouwen. TSG 1999; 77:105-115.

29. Jacobs DR Jr, Ainsworth BE, Hartman T] et al: A simultaneous ewaluation of 10 commonlly used physical activity questionnaires. Med Sci Sports Exerc 1993;25(1):81-91.

30. Weller IM. Corey PN: A study of the reliability of the Canada Fitness Survey questionnatre. Med Sci Sports Exerc 1998; 30(10):1530-1536.

31. Vogel JA, Crowdy JP. Amor AF et al: Changes in aerobic fincess and body fat during army rectuil training. Eur J Appl Physiol 1978; 40(1): 37-43.

32. Stacy RJ, Hungerford RL, McMahon $B B$ : The effect of basic training on acrobic capacicy and body far in New Zealand arny recruits. N Z Med J 1982; 95(722):876-878.

33. Jones BH, Cowan DN, Tomlinson JP et al : Epidemiology of injuries associated with physical training among young men in the army. Med Sci Sports Exerc 1993; 25(2): 197-203.

34. Jones BH, Bowee MW, Harris JM 3d et all Intrinsic risk factors for exercise-related injuries among male and female army trainees. Am J Sports Med 1993; 21 (5): 705-710. 
35. Jordan $G$ schwellnus MP. The incidence of overuse injuries in miliaty rectuts during basic military training. Mil Med 199:; 159(6):421-426.

36. Almeida $\$ A_{\text {is }}$ Williams KM, Shaffer RA et al: Epidemiological patterns of musculoskeletal injuries and physical training. Mied Sci Sports Exerc 1999; 31(8):1176-1182.

37. Pope RP. Herbert R. Kirwan JD et al Predicting attrition in basic milhtary traning. Mil Med 1999; 164(19): 710 714.

38. Ross f, Woodward A Risk Eactors for injury during basic military training. Is there a social elemeat to injury pathogenesis? ] Occup Med 1994; 36(10): 1120-1126.

39. Rudzki Sy: Injuries in Australian Arny recruits. Part ILI: The accuracy of a pretraining or thopedic sereen in predicting ultimate injury outcome. Mil Med 1997; 162(7):481 -483.

40. Stevention JM, Bryant JT, Andrew GM et al: Developnent of plyysical fitness standards for Canadian Armed Forces younger persomel. Can J Sport Sci 1992; 17(3):214-221.

41. Chin DL - Blackwood GV - Gackstetter GD: Ergometry as a predictor of basic military training success. Mil Med 1996; 161(2):75-77.

42. Williams $A G$, Rayson MP, Jones DA: Effects of basic training on material handling ability and physical fitness of British Army recruits. Ergonomics 1999; 49(8):1114-1124.

43. Rayson M, Holliman D, Belyavin A: Development of plysical selection procedures for the British Army. Phase 2: relationship between physical performance tests and criterion tasks. Ergonomics 2000; 43(1):73-105.

44. McCraw RK, Bearden DL: Personality factors in failure to adapt to the military. Mil Med $1990 ; 155(3): 127-130$.

45. Carbone EG, Cigrang JA, Todd SL et al: Predicting outcome of military basic training for individuals referred for psychological evaluation.J Pers Assess 1999; 72(2):256-265.

46. Cawfond SL, Fiedler ER: Childhood physical and sexual abuse and failure to complete military basic training. Mil Med 1992; $157(12): 645-648$.

47. Klein Hesselink DJ, Krutidenier HJ, Veerman TJ et al: Afwezigheid werklard. Een literatuurstudie naar determinanten van ziekteverzuim en arbeidsongeschiktheid. NJ.A. Ansterdinn, 1993.

48. Talcott GW, Haddock CK, Klesges RC et al: Prevalence and predictors of discharge in United States Air Force Basic Military Training. Mil Med 1999; 164(4):269-274.

49. Broersen IPJ, Weel ANH, Dijk FII wan: Periodiek Bedrijfsgeneeskundig Onderzoek; middel en matarsaf. Ansterdam, 1989.

50. Hulsho C TJ: Algemene Richtijn Aanstellingskeuringen. Amsterdam: SKB, 1999.

51. Rand J de, Peters JHM, Groot RP de et al: Modernisering van het keuringssysteem bij de Koninklijke Landmacht, keuringsprotocollen en functioneel beoordelen. TBV 2000; $8: 110-115$

52. Altun DC: Lractical statistics for medical research. London: Chapman and Hall, 1991.

53. Steinijans VW, Diletti E, Bömches B er al: Interobserver agreement: Cohens Kappa coeffcient does not necessarily reflect the percentage of patients with congruent classifications. Int J of Clin of Pharm And Ther. 1997; 35; 3:93-95.

54. Rand J de: Vragenlijsten bij periodiek bedrijfsgezondheidkundig onderzoek en het nut woor de Koninklijke Landmacht, een literatuurstudie. Leiden, 1993.

55. Putten DJ wan, Marcelissen FGH, Winter CJ de: De vragenlijst voor PBGO 1-4. Achtergronden woor het gebruk erwan. Het wijzigen wan antwoorden door bedrijfartsen. Methoden woor gebruik van referentiegegevens. TSG 1988; 66:115-120, 143-147.

56. Putten Dy wan: De vagenlijst voor $\mathrm{PBGO}$, voorstellen tot wijziging van de vragenlijst. Leiden, NIPG/TNO, 1989. 


\section{2 | De beperkingen van medische beperkingen}

In belangrijke mate gebaseerd op: Raad J de, Reulings PGJ, Schouten HJA: De beperkingen van medische beperkingen. Ned Mil Geneesk T 1996; 49: 106-111. 


\subsection{Inleiding en vraagstelling van dit onderzoek}

Naar aanleiding van de omvorming naar een beroepsleger en de uitbreiding van de takstelling met het uitvoeren van missies buiten de eigen landsgrenzen, onderging de Koninklijke Landmacht (KL) in 1994 een reorganisatie. Er was in de KJ zowel sprake van personele overtolligheid als van personeel dat vermoedelijk niet geschikt was om de nieuwe taakstelling uit te voeren. Daarom werd een onderzoek gehouden naar de kansen op behoud van werk voor beroepsmilitairen (Project Loopbaanprognose). Als onderdeel hiervan werd beoordeeld of de beroepsmilitairen in de toekomst inzerbaar zouden zijn op medische gronden. Die beoordeling vond plats op basis van de keuringsuitslag van het laatst gehouden periodiek geneeskundig onderzoek (PGO). Op grond van deze beoordeling deed zich een antal vragen voor over de keuringsprocedure die bij de KL werd gevolgd bij dat PGO.

Bij het PGO werd de beroepsmilitair beoordeeld, zoals vermeld in het Militair Keuringsreglement (MKR), op aanwezigheid van ziekten en gebreken. Als consequentie werd de gekeurde militair in een bepalde categorie op grond wan de zogenoende ABOHZIS-classificatie ingedeeld (zie onder), waarbij zo nodig (medische en functionerings-) beperkingen werden verstrekt.

Omdat aan deze handelwijze anders dan voorheen het geval was - op grond van de reorganisatie en dreigende overtolligheid - serieuze (rechtspasitionele) consequenties werden verbonden, deed zich de vraag voor of en in hoeverre de op die manier tot stand gekomen uitspraken voldoende betrouwbar waren. Recente publicaties van Post-Uiterweer [1] en De Kort [2] inzake keuringen bij de RBB en meer algemeen in Nederland, gaven aanleiding om zich af te vragen of de betrouwbaarheid van deze keuringen bij de KL volstond.

Er was nooit onderzoek verricht naar de mate van overeenkomst tussen de beoordelingen van keurend artsen volgens de ABOHZIS-classificatie of naar het verband tussen die classificatie en de daaruit voortvloeiende te verstrekken beperkingen. Gelet op het belang dat bij de reorganisatie aan deze keuring werd toegekend, lag het voor de hand on zulk onderzoek te verrichten.

De vraagstelling voor dat onderzoek luidt: "Is de beoordeling van de ABOHZIS-classificatie en de medische beperkingen, zoals die bij het PGO van de KL worden vastgesteld, voldoende reproduceerbaar, en komt de gegeven ABOHZIS-classificatie overeen met de toegekende medische beperkingen?"

\subsection{Achtergrondinformatie}

Tussen 1960 en 1995 werden beroepsmilitairen van de Koninklijke Landmacht middels het PGO (doorgaans on de vijf jaar) gekeurd on te beoordelen of zij 
op medische gronden nog geschikt waren om als militair te kunnen blywen functioneren. De militair werd opgeroepen om bij éen van de twee ketringsraden te verschijnen. De keurend arts had bij dit onderzoek inage in het medisch dossier van de militar in kweste. Het PGO zelf bestond uit een gestandaardiseerde anamnese, lichamelijk onderzoek en arvullende onderzoeksgegevens, te weten een rust-ecg, audiometric, de bepaling van de visus, onderzoek nara het kleuronderscheidend vermogen en urineonderzoek.

Naar aanleiding van de gevonden resultaten werd elke vijf jaar voor het militair beroepspersoneel een niewwe ABOHZIS-classificatie opgesteld. De letters ABOHZIS stan voor Algemene fysieke toestand, Bovenste extremiteiten, Onderste extremiteiten, Horen, Zien, Intelligentie en Stabiliteit. Voor elk van deze deelgebieden werd een indeling in vijf classificaties gehanteerd, lopend van én tot vijf (bijvoorbeeld $\mathrm{A}_{1}, \mathrm{~B}_{2}, \mathrm{O}_{3}$ etc.). Daarbij betekende een 1-classificatie dat men niet in het minst aan een in het $\mathrm{MKR}$ vermelde ziekte of gebrek leed, hetgeen in toenemende mate wel in geval was indien men een 2-classificatie of hoger kreeg. De constatering van een classificatie tussen 2 en 4 leidde tot het opleggen van éen of meer medische en functioneringsbeperkingen. De constatering van een 5-classificatie betekende formeel dat de betrokken millitair dienstongeschikt was en moest worden afgekeurd. Voor de medische beperkingen werd van een standaardlijst gebruik gemakt. Deze ljst was naar analogie van de $A B O H Z I S$-classificatie eveneens verdeeld in de rubrieken $A, B O, H, Z$, I en $S$, waarbij elke specifieke beperking van een nummer was voorzien, zoals. bijvoorbeeld $\mathrm{AO2}$ ("geen hindernisbaan), $\mathrm{O} 10$ ("geen zware rugbelasting"), B10 ("geen zware nekbelasting"), SO7 ("mag geen geestelijk stresserende werkzaamheden verrichten").

Zowel de medische als de daaran gekoppelde functioneringsbeperkingen werden vervolgens an de betreffende militaii en diens commandant bekend gesteld. De commandant kon bepalen of deze militair de opgedragen werkzammeden al dan niet kon uitvoeren. Eventueel kon de militaire dienstgeschiktheid van de militair door de commandant ter discussie worden gesteld. In het algemeen leidden de opgelegde beperkingen bij militairen niet tot verregaande consequenties, althans tot 1994. Er bestond een gesloten personeelssysteem voor militairen, men werd geacht "voor de gehele dutur van de loopbaan te zijn arrgesteld".

Een groot nadeel van de gehanteerde werkwijze was dat wel een beoordeling van de belastbaarheid werd opgemaakt, mar dat er geen sprake was van concreet inzicht in de werkelijke belasting: er werden wel functioneringsbeperkingen opgelegd, mar van functie-eisen was geen sprake. Een tweede nadeel was dat de ruimte voor het opleggen van een lagere $A B O H Z I S-c l a s s i f i c a t i e$ in de loop der jaren was gekrompen. Kon de arts oorspronkelijk per deelgebied in 
de $A, B, O, H, Z$ van de gradaties 1 naar 4 beperkingen opleggen, inmiddels was woor de gehele classificatie de ondergrens voor geschiktheid opgetrokken naar ten hoogste 2 of 3 , waronder zich de gradatie X bevond, welke laatste classificatie dienstongeschiktheid inhield. Hierdoor werden de mogelijkheden tot nuancering sterk ingekrompen, ofschoon die mogeliykheid tot nuancering nu juist de reden was dat dit systeem oorspronkelijk in gebruik was genomen [3]. Voorts was er kritiek op de koppeling van het keuringssysteem met de ABOHZIS-classificatie, die tot een te grote inperking van de professionele autonomie van de arts zou leiden [4]. Daarnaast bleek dat de indeling op grond van de $\mathrm{ABOHZIS-classificatie} \mathrm{zelf} \mathrm{te} \mathrm{weinig} \mathrm{relatie} \mathrm{met} \mathrm{de} \mathrm{feitelijke} \mathrm{militaire}$ werkzaamheden vertoonde [5].

Ten gevolge van de Defensienota uit 1991 en de Prioriteitennota uit 1993 werd de taakstelling van de $\mathrm{KL}$ uitgebreid, onder gelijktijdige omvorming naar een beroepsleger. De nieuwe takstelling bracht een verzwaring van de belasting met zich mee. Daarnaast bleek er overtolligheid onder beroepsmilitairen te bestaan, waardoor niet voor elke beroepsmilitair werk kon worden gegarandeerd. Hierdoor ontstond grotere belangstelling bij de KL-leiding voor de actuele medische inzetbaarheid van de individuele militair dan voorheen. De werkgever - de Bevelhebber der Landstrijdkrachten (BLS) - wenste militairen zonder beperkingen te kunnen inzetten. Aan het te werk stellen van militairen met ernstige medische en/of functioneringsbeperkingen werd een einde gemaakt. Als gevolg daarvan werd bij het overtolligheidonderzoek dat in 1.994 startte ook aandacht geschonken aan de individuele medische beperkingen.

\subsection{Materiaal en methoden}

\subsubsection{Keuringsdossiers}

Uit een bestand van 200 dossiers van recente (minder dan 6 maanden oude) PGO's, die door de arts van de ene keuringsraad waren verricht, zijn 24 dossiers aselect gekozen. Alle 200 dossiers werden voorzien van een opeenvolgend nummer, waarna een medewerker 24 toevalsgetallen [6] uitkoos. De dossiers zijn geanonimiseerd en ontdaan van de vastgestelde ABOHZIS-classificatie en medische beperkingen. Alle overige informatie, met inbegrip van correspondentie met eventuele geconsulteerde $k$ linisch specialisten, was overgenomen. Onder de betreffende dossiers bevonden zich 6 dossiers van militairen waarbij geen beperkingen waren vastgesteld ten aanzien van de $\mathrm{A}-$, $\mathrm{B}$ - en $\mathrm{O}$-classificatie.

Deze 24 keuringsdossiers zijn ter beoordeling aangeboden aan twee artsen van de andere keuringstaad (Figuur 10); één ervaren keurend arts en één arts met 


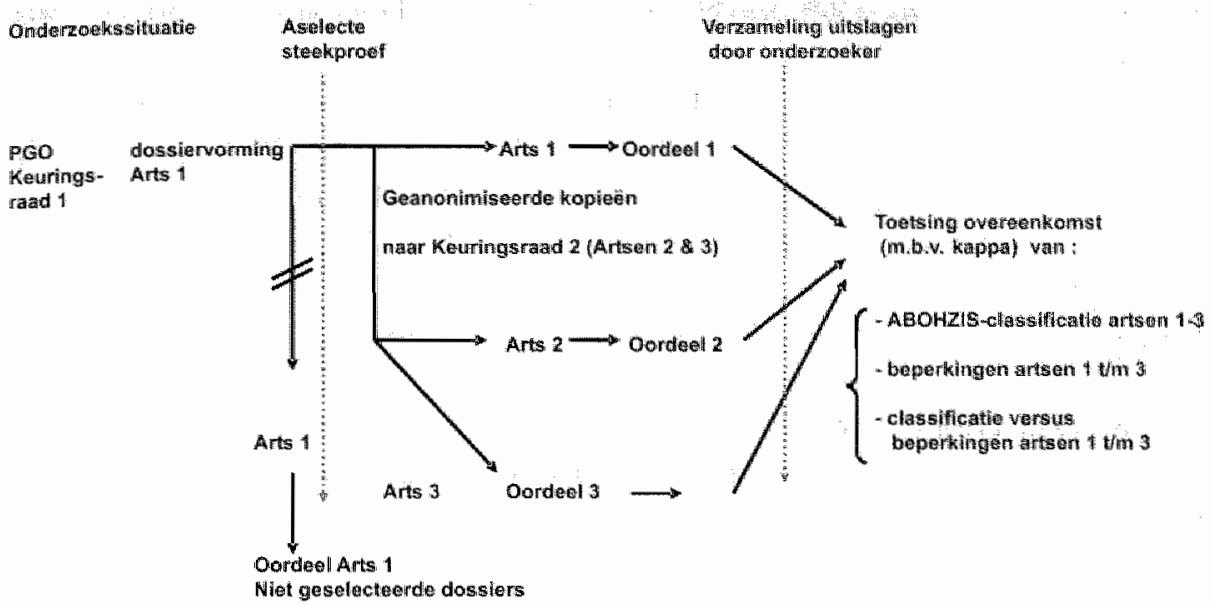

Figuur 10: De onderzoeksopzet van hoofdstuk 2.

24 aselect gekozen keuringsdossiers, afkomstig van één keuringstad, worden gennonimiseerd aan twee artsen wan de andere keuringrad angeboden met het verzoek om zowel de

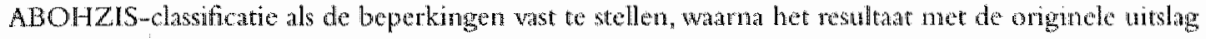
wordt vergeleken met behullp van de kappa en PD.

ongeveer 6 maanden werkervaring. Aan beide artsen is gevraagd om zowel de ABOHZIS-classificatie als de medische beperkingen vast te stellen. De beoordeling van de oorspronkelijke arts (beoordelaar 1 ) is verwolgens vergeleken met de beoordeling van de ervaren arts (beoordelaar 2) en de minder ervaren arts (beoordelaar 3).

\subsubsection{Statistische methoden}

Er bestan meerdere methoden om de mate van overeenstemming te berekenen $[1,7]$. Eén van deze methoden is het berekenen van de kappa (figur 11). De waarde wan kappa warieert tussen 0 en 1 (figuur 11). Voor het beoordelen van screeningstesten wordt vak aan een bepaalde waarde van kappa een kwalificatie gekoppeld. Bouter en van Dongen [7] vermelden dat een kappa tussen de 0,40 en 0.75 voor diagnostische testen in de klinische diagnostiek gebruikelijk is. Een wat uitgebreider indeling is die warbij een kappa $<0,40$ aangeeft dat er sprake is van een geringe overeenstemming, een kappa tussen 0,40 en 0,60 dat er sprake is van een redelijke overeenstemming, een kappa tussen 0,60 en 0,75 dat er sprake is van een goede overeenstemming en een kappa van boven de 0,75 dat er sprake is van een voortreffelijke overeenstemming. De mate van overeenkomst tussen de drie beoordelaars wordt aan de hand van de groeps-kappa 
weergegeven [8]; dit geldt zowel voor de ABOHZIS-classificatie als voor de medische beperkingen.

De belangrijkste parameters van de ABOHZIS-classificate die bij de uitslag van het $\mathrm{PGO}$ een rol spelen zijn de $\mathrm{A}-\mathrm{B}$ - en $\mathrm{O}$-classificatie. $\mathrm{Om}$ die reden wordt de kappa uitsluitend voor deze drie classificaties berekend. Om de mate van overeenstemming tussen de artsen met betrekking tot de A-, B- en O-classificatie wast te stellen, worden per rubriek twee kappa-waarden berekend. De eerste kappa geeft de mate van overeenstemming op de vier afzonderlijke scores van 1 , $2, \mathrm{X}$ of ? weer. De tweede kappa betreft de overeenstemming op de score van 1 tegenover de combinatie $2, X$ of? De scores 2 , $X$ en ? worden daarbij als gelijkwaardig gezien en geven aan dat een ziekte of gebrek in enigerlei mate aanwezig is.

Bij de medische beperkingen wordt de overeenstemming beoordeeld tussen het wel of niet toekennen van een beperking op een bepaalde rubriek. Om dichotomie te bewerkstelligen en aldus gecorreleerde kappa's met elkaar te kunnen vergelijken is de "jackknife techniek" gebruikt, analoog aan de gepaarde t-toets [9].

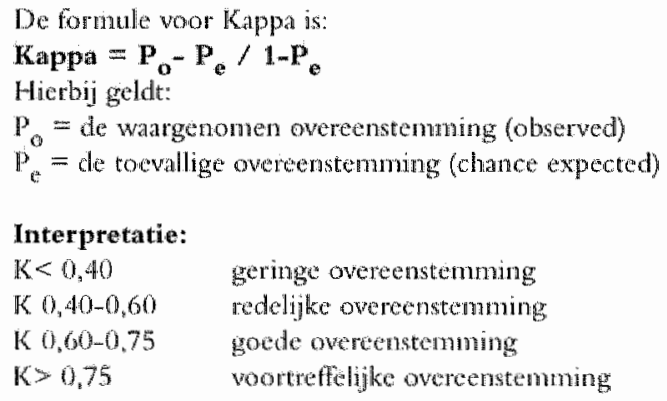

Figunar 11. De betekenis van kappa.

Tenslotte wordt onderzocht of de artsen consequent omgaan met her toekennen van medische beperkingen. De overeenkomst tussen de beperkingen in termen van de $\mathrm{A}-, \mathrm{B}$ - of $\mathrm{O}$-classificatie en de medische beperkingen wordt voor elke arts vastgesteld met behulp van de kappa. Daarbij worden gedichotomiseerde variabelen met elkaar wergeleken. $\mathrm{Er}$ is overeenstemming indien de arts enerzijds een $A 1, B 1$ of $O 1$ verstrekt terwijl hij/zij tegelijk op deze rubriek geen medische beperkingen aangeeft. Evenzeer dient bij een andere dan een $1-$ classificatie nu juist wel medische beperkingen te worden vermeld. 
Als tweede mat om de reproducerbarheid vast te stellen is het percentage discordante of discongruente uitslagen gebruikt, zoals in het panelonderzok van De Kort en Post-Uiterweer [1] is gehanteerd: $(\mathrm{GO}+\mathrm{OG} / \mathrm{GG}+\mathrm{GO}+$ $\mathrm{OG}+\mathrm{OO}) \times 100 \%$.

\subsection{Resultaten}

\subsubsection{De A-, B- en O-classificatie}

In tabel 9 is voor alle 24 keuringsformulieren de toegekende ABOHZIS-classificatie van de drie beoordelaars weergegeven. De oorspronkelijke beoordelaar heeft gebruik gemakt van de mogelijkheid om een ABOHZIS-classificatie van 1,2 respectievelijk $X$ te verstrekken. Beoordelaars 2 en 3 gebruikten soms daarnaast "?" als score. In de dagelijkse praktijk hebben de beoordelaars 2 en 3 de mogelijkheid om dit vraagteken vervolgens voor te leggen an het hoofd van de keuringsraad.

\subsubsection{Medische beperkingen}

In tabel 10 staan de medische beperkingen weergegeven, zoals de verschillende artsen deze per dossier hebben vermeld. De codes stan voor specifieke medjsche beperkingen, zoals onder "achtergrondinformatie" is weergegeven. Het is moeilijk an te geven of de keurend artsen inhoudelijk overeenstemmen in de toekenning van de medische beperkingen. Inhoudelijk is de betekenis van de betreffende beperkingen niet altijd medisch van aard, regelmatig hebben beperkingen het karakter van een functioneringsbeperking. Daarmast is er overlap tussen de rubrieken, een antal beperkingen afkomstig uit verschillende rubrieken zijn identiek.

\subsubsection{De mate van onderlinge overeenstemming bij de A-, B-, en O-classificatie en de onderlinge overeenstemming bij de medische beperkingen}

In tabel 11 zijn de kappa's voor alle drie de beoordelars tezamen weergegeven, zowel voor wat de ABOHZIS-classificatie betreft als voor de medische beperkingen.

De mate van overeenkomst is per A-, B-, of O-rubriek beoordeeld. De earste kappa die wordt vermeld (tweede kolom; "Kappa 1, 2, X, ?") geldt voor de afzonderlijke $\mathrm{A}-\mathrm{B}$ - of O-scores, zijnde 1,2, $\mathrm{X}$ of?. Deze eerste kappa-waarde geeft aan dat de mate van overeenstemming per rubriek verschillend is. De overeenkomst tussen de artsen bij de A-rubriek is gering; de overeenstemming bij de $\mathrm{B}$-en O-rubriek is redelijk. 
Tabel 9. De dover de 3 artsen bij de 24 PGO's toegekende ABOHZlS-classificaties.

\begin{tabular}{|c|c|c|c|c|c|c|c|c|c|c|c|c|c|c|c|c|c|c|c|c|c|}
\hline \multirow{2}{*}{$\begin{array}{l}\text { Formulier } \\
\text { Nummer }\end{array}$} & \multicolumn{7}{|c|}{ Bewordelatat 1} & \multicolumn{7}{|c|}{ Beoordelar 2} & \multicolumn{7}{|c|}{ Beoordelaar 3} \\
\hline & $A$ & $\mathrm{~B}$ & 6 & $H$ & $\mathbf{Z}$ & 1 & $\mathrm{~s}$ & A & $B$ & 0 & $H$ & $z$ & I & $\$$ & A & $B$ & 0 & $\mathrm{H}$ & $z$ & 1 & 5 \\
\hline 1 & 1 & 1 & 2 & 2 & 2 & 1 & 1 & 1 & $\mathbb{1}$ & 1 & 2 & $\mathrm{x}$ & 1 & 1 & 1 & 1 & $?$ & 2 & $?$ & 1 & $\mathbb{1}$ \\
\hline 2 & 2 & 1 & 1 & 2 & 1 & 1 & $\mathbb{1}$ & $x$ & 1 & $\mathbb{1}$ & 2 & 1 & $\mathbb{1}$ & 1 & $x$ & 1 & 1 & 2 & 1 & 1 & 1 \\
\hline 3 & 1 & 1 & 2 & 1 & 1 & 1 & 1 & 2 & 1 & $x$ & $?$ & 1 & $\mathbb{1}$ & 1 & $?$ & 1 & $\mathrm{x}$ & 1 & 1 & 1 & 1 \\
\hline 4 & 2 & 1 & 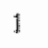 & 1 & 2 & 1 & 1 & 2 & 1 & 1 & 1 & $?$ & 1 & 1 & 2 & 1 & 2 & 1 & $?$ & 1 & 1 \\
\hline 5 & 1 & 1 & 2 & 1 & 2 & l & 2 & 1 & 1 & $x$ & 1 & 3 & 1 & 1 & $?$ & 1 & 2 & 1 & $?$ & 1 & 2 \\
\hline 6 & 2 & 1 & 1 & 1 & 2 & 1 & 1 & 2 & 1 & 1 & 1 & $?$ & 1 & 1 & $?$ & 1 & 1 & $\mathbb{1}$ & $?$ & 1 & 1 \\
\hline $7 *$ & 1 & 1 & 2 & 1 & 2 & 1 & 1 & 1 & $\mathbb{1}$ & x & 1 & 2 & 1 & 1 & $?$ & 1 & 2 & 1 & 2 & 1 & 1 \\
\hline 8 & 2 & 2 & 2 & 1 & 2 & $\mathbb{1}$ & 2 & 2 & 2 & $x$ & $?$ & $?$ & 1 & 2 & ? & 2 & $x$ & $?$ & 2 & 1 & 2 \\
\hline $9 *$ & 2 & 1 & 2 & 1 & 1 & i & 1 & 2 & $?$ & $?$ & 1 & 1 & 1 & 1 & $?$ & 1 & 2 & $\mathbb{1}$ & 1 & 1 & 1 \\
\hline 10 & 2 & 1 & 1 & 1 & 2 & 1 & 1 & 1 & $\mathbb{1}$ & 1 & 1 & $x$ & 1 & 1 & $?$ & 1 & $x$ & 1 & $x$ & 1 & 1 \\
\hline 11 & 2 & I & 2 & 1 & 1 & 1 & 1 & $\mathrm{x}$ & 1 & 2 & 1 & 1 & 1 & 1 & $?$ & 1 & 2 & 1 & 1 & 1 & $\|$ \\
\hline $12^{*}$ & 2 & 1 & 1 & 1. & 1 & 1 & 1 & 2 & 1 & 1 & : & $?$ & 1 & 1 & $?$ & 2 & 1 & $?$ & 1 & 1 & 1 \\
\hline 13 & 1 & 1 & $x$ & 1 & 2 & 1 & 1 & $?$ & $?$ & $x$ & 1 & 2 & $?$ & $?$ & $?$ & 1 & $x$ & 1 & 2 & 1 & 1 \\
\hline 14 & 2 & 1 & 1 & 1 & 1 & 1 & 1 & $x$ & 1. & 1 & 1 & 1 & 1 & 1 & $?$ & 1 & $\|$ & 1 & 1 & 1 & 1 \\
\hline 15 & 2 & 1 & 1 & 2 & $\|$ & 1 & 1 & $x$ & 1 & 1 & 2 & 1 & 1 & 1 & $?$ & 1 & 1 & $?$ & 1 & 1 & 1 \\
\hline $16 *$ & 1 & 2 & 1 & 2 & 1 & 1 & 1 & 2 & 1 & 1 & $?$ & $\mathbb{1}$ & 1 & 1 & $?$ & 2 & 1 & $?$ & 1 & 1 & 1 \\
\hline 1.7 & 2 & 2 & 2 & 2 & 2 & 1 & 1 & $x$ & 2 & 2 & $?$ & 2 & 1 & 1 & $x$ & 2 & 2 & $?$ & $?$ & 1 & 1 \\
\hline 18 & 1 & 1. & 2 & 1 & 2 & 1 & 1 & 1 & 1 & $x$ & 1 & $x$ & 1 & 1 & $?$ & 1 & $x$ & 1 & $?$ & 1 & 1 \\
\hline 19 & 2 & 1 & 2 & 1 & 1 & 1 & 1 & $x$ & 1 & 2 & 1 & $\mathbb{1}$ & 1 & 1 & $x$ & 1 & 1 & 1 & 1 & 1 & 1 \\
\hline $20 *$ & 2 & 1 & 1. & 1 & 1 & 1 & 1 & $\mathrm{x}$ & 1 & 1 & 2 & 1 & 1 & 1 & 2 & 1 & $\mathbb{1}$ & 1 & 1 & 1 & 1 \\
\hline 21 & 2 & 1 & 1 & 1 & 2 & $\mathrm{I}$ & 1 & $x$ & 1 & 1 & 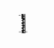 & 2 & 1 & 1 & $\mathrm{x}$ & $?$ & $?$ & 1 & $?$ & 1 & 1 \\
\hline 22 & 2 & 1 & $x$ & 2 & 1. & 1 & 1 & $x$ & $\Perp$ & $x$ & $x$ & $?$ & $x$ & 1 & $?$ & $\mathbb{1}$ & 2 & $?$ & $x$ & 1 & 1 \\
\hline $23 *$ & 1 & 2 & 2 & 1 & 1 & 1 & 1 & 1 & 2 & 2 & 1 & 1 & 1 & $\|$ & $?$ & $x$ & 1 & $?$ & 1 & 1 & 1 \\
\hline 24 & $x$ & 1 & 1 & 1 & 2 & 1 & 1 & $\mathrm{x}$ & 1 & 1 & $?$ & 2 & 1 & 1 & $\mathrm{x}$ & 1 & 1 & $?$ & $?$ & 1 & 1 \\
\hline
\end{tabular}

*: Oorspronkelijk gen medische beperkingen. Beaordelaar 1: oorspronkelijke keurend arts; beoondelar 2 cervaren keurend arts; beoondelaar 3: niet-ervaren keurend arts.

De tweede kappa geeft de overeenstemming weer bij het vaststellen of er wel of geen (" $/ /{ }^{\text {") }}$ ziekte of gebrek is. Daartoe zijn de 1-classificaties dichotoom tegenover alle andere classificaties $(2, X$, ?) geplaatst, zoals in paragraaf 2.3 .2 onder "statistische methoden" reeds is aangegeven. In de volgende kolommen -de vierde en vijfde - wordt op basis van dezelfde dichotome verdeling als uit de 


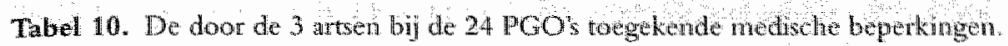

\begin{tabular}{|c|c|c|c|}
\hline \multirow[b]{2}{*}{$\begin{array}{l}\text { Formulier } \\
\text { Nummer }\end{array}$} & \multicolumn{3}{|l|}{ Boperkingen $\mathrm{ABOHZLS}$} \\
\hline & Beootdelaar 1 & Beoordelan 2 & Heoorde latr 3 \\
\hline 1 & $\mathrm{H}: 4$ & $\mathrm{H}: 4$ & \\
\hline 2 & $A: G$ & $A: 6,43, x$ & $A: 9.43$ \\
\hline 3 & $A: 200: 4,18,20$ & $A: 200: 4,19$ & $A: 20: 0: 4$ \\
\hline 4 & $A: 5,6,8, y$ & A: $5,6,34$ & $A: 6,9, y$ \\
\hline 5 & $0: 7,11,18,20,27$ & $0: 7,18,19,20,27,30$ & $0: 7,18,27$ \\
\hline 6 & A: $6,34+0: 30$ & A: $20 \mathrm{~S}: 14$ & \\
\hline \multicolumn{4}{|l|}{$7 *$} \\
\hline 8 & A: $20 \mathrm{~B}: 12,21 \mathrm{O}: \mathrm{W}: 14$ & $A: 20 \mathrm{~S}: 14$ & \\
\hline \multicolumn{4}{|l|}{$9 *$} \\
\hline 10 & $A=14$ & & \\
\hline 11 & $0: 10,27$ & & $0: 10$ \\
\hline \multicolumn{4}{|l|}{$12 *$} \\
\hline 13 & A: $200: 7,18,20,27,28,36, z$ & $0: 7,27,30$ & $0: 7,18,27$ \\
\hline 14 & $A: 6, x$ & A: $6, x$ & \\
\hline 15 & $A: 6,34$ & A: $6 \mathrm{H}: 4$ & $A: 10, x$ \\
\hline $16 \star$ & $\mathrm{H}: 4$ & & \\
\hline 17 & $\begin{array}{l}\mathrm{B}: 4,10,17,21 \mathrm{O}: 10,18,21,27 \\
\mathrm{H}: 4 \mathrm{~S}: 11\end{array}$ & $\begin{array}{l}\text { A: } 6,9,20 \mathrm{~B}: 4,7,10,14,17 \\
\text { O: } 10,18,20\end{array}$ & $A: 6 \mathrm{~B}: 7,10$ \\
\hline 18 & $0: 10,14+, 18,20,27, x$ & $0: 10,14$ & $0: 10,18,27$ \\
\hline 19 & $A=6,200,11,14,18,20+$ & A: $9,11,24$ & $A: 20, x$ \\
\hline $20 *$ & & $A: 6,20,3$ औ & \\
\hline 21 & $A: 6,12, \times S: 7$ & $A: 5,6,12,34$ & $A: 12$ \\
\hline 22 & $0: 9,12,14,27$ & & \\
\hline \multicolumn{4}{|l|}{$23 *$} \\
\hline 24 & A: $6,9,11, x$ & A: $9,11,24$ & $A: 6,11, x$ \\
\hline
\end{tabular}

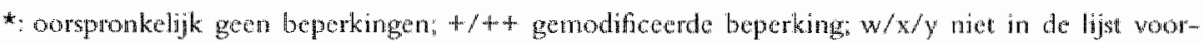
komende beperkingen

derde kolom het percentage discordante uitslagen en de bijbehorende standaardafwijking weergegeven.

In de zesde kolom wordt de overeenstemming ("Kappa") bij de medische beperkingen beoordeeld, met behulp van de "Jackknife techniek" teneinde 
Tabel 11. De nate wan owerenkenst wusen de beordelans met berekkng tot de rubrieken A, B en

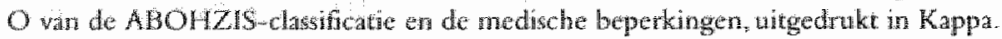

\begin{tabular}{|c|c|c|c|c|c|c|c|c|}
\hline \multirow[b]{2}{*}{$\begin{array}{l}\text { ABOHZI- } \\
\text { rubrick }\end{array}$} & \multicolumn{4}{|c|}{ ABOHZIS-classificatic } & \multicolumn{4}{|c|}{$\begin{array}{l}\text { Medisclie beperkingen } \\
\text { "Jacknife techniek" }\end{array}$} \\
\hline & $\begin{array}{l}\text { Kappa } \\
1,2, X\end{array}$ & $\begin{array}{l}\text { Kappa } \\
+/-z i c k t e \\
\text { (dichoroom) }\end{array}$ & PDOH & $\mathrm{SD} \%$ & Kappa & $\mathrm{P}$ & PD\% & SD\% \\
\hline$A$ & 0,46 & 0.32 & 20,8 & 11,8 & 0,67 & 0,07 & 20,8 & 5,9 \\
\hline$B$ & 0,52 & 0,58 & 10.4 & 2,9 & 0.74 & 0,10 & 2,8 & 2,4 \\
\hline 0 & 0,44 & 0,67 & $\$ 2,5$ & 11,8 & 0,65 & 0,10 & 16,7 & 0 \\
\hline
\end{tabular}

PD state voor percentage discongruente mibsagen tussen de beoordelars 2 en 3 versus beoordelat: 1 en ad woo de standardafwigking datrvan. Verdere toelichning wordt in de takst herondar weergegeven.

dichotomie te bewerkstelligen (paragraaf 2.3.2 "statistische methoden") met in de volgende kolom de bijbehorende p-waarde (telkens $>0,05$ ). Van diezelfde dichotome verdeling wordt in de laatste twee kolommen het percentage discordante uitslagen en de bijbehorende standaardafwijking weergegeven.

\subsubsection{De overeenkomst tussen de ABOHZIS-classificatie en de medische beperkingen per beoordelaar}

In tabel 12 staat angegeven in hoeverre de drie artsen bij de A-, B- en O-rubriek consequent omgaan met het toekennen van medische beperkingen. Bij elke arts is per rubriek de relatie tussen de verstrekte $\mathrm{A}-, \mathrm{B}$ - of $\mathrm{O}$-score en het wel of niet toekennen van een medische beperking op de betreffende rubrick vastgesteld.

De overeenkomst tussen de ABOHZIS-classificatie en de medische beperkingen bij de oorspronkelijke beoordelaar is redelijk tot goed. Bij de andere twee beoordelaars is de overeenkomst geringer, namelijk slecht tot redelijk. Alle drie artsen zijn het met elkaar eens dat bij een A1, B1 of O1 geen medische beperkingen worden toegekend. Echter, het komt wakk voor dat geen medische beperkingen worden toegekend indien de ABOHZIS-classificatie niet 1 is, maar $2, X$ of?

De percentages discongruentie (PD) tussen de beoordelaar 1 enerzijds en de beoordelaars 2 en 3 anderzijds zijn voor de relatie tussen beperkingen en A-classificatie $34,7 \pm 16,8 \%$, voor de relatie tussen beperkingen en B-classificatie 13,9 $\pm 4,8 \%$ en voor de rellatie tussen beperkingen en O-classificatie $26,4 \pm 13,4 \%$. 
Tabel 12. De overeenkomst trassen de toegekende ABOHZIS-classifextiten de medische beperkingen bij de drie beoordelars.

\begin{tabular}{|c|c|c|c|c|c|c|c|c|c|c|c|c|c|}
\hline \multirow{3}{*}{\multicolumn{2}{|c|}{$\begin{array}{l}\text { ABOHZIS } \\
\text { Classificatie }\end{array}$}} & \multirow{2}{*}{\multicolumn{4}{|c|}{$\begin{array}{l}\text { Beoordelaar } 1 \\
\text { Medische beperking }\end{array}$}} & \multirow{2}{*}{\multicolumn{4}{|c|}{$\begin{array}{l}\text { Beoordelar } 2 \\
\text { Medische beperking }\end{array}$}} & \multirow{2}{*}{\multicolumn{4}{|c|}{$\begin{array}{l}\text { Beodrdclat } 3 \\
\text { Motische beperking }\end{array}$}} \\
\hline & & & & & & & & & & & & & \\
\hline & & Nee & $\mathrm{Ja}$ & Kappa & SD & $\mathrm{Nec}$ & $\mathrm{Ja}$ & Kapp & SD & Nee. & Ja & Kappa & $\mathrm{SD}$ \\
\hline \multirow[t]{3}{*}{ A } & $A 1$ & 7 & 1 & & & 5 & 0 & & & 1 & 0 & & \\
\hline & $A 2, A x, A$ ? & 5 & 11 & & & 6 & 13 & & & 13 & 10 & & \\
\hline & & & & 0,43 & 0,32 & & & 0,47 & 0.32 & & & 0,10 & 0,18 \\
\hline \multirow[t]{3}{*}{$B$} & BI & 20 & 0 & & & 19 & 0 & & & 18 & 0 & & \\
\hline & $\mathrm{B} 2, \mathrm{Bx}, \mathrm{BP}$ & 2 & 2 & & & 4 & 1 & & & 4 & 2 & & \\
\hline & & & & 0,63 & 0.47 & & & 0,28 & 0.45 & & & 0,43 & 0,42 \\
\hline \multirow[t]{3}{*}{0} & 01 & 11 & 0 & & & 13 & 0 & & & 10 & 0 & & \\
\hline & $\mathrm{O} 2, \mathrm{Ox}, \mathrm{O} ?$ & 4 & 9 & & & 5 & 6 & & & 10 & 4 & & \\
\hline & & & & 0,67 & 0,28 & & & 0,57 & 0,30 & & & 0.25 & 0,24 \\
\hline
\end{tabular}

sid stanat voor de standartlafwijking.

\subsection{Beschouwing}

Hoewel de overeenkomsten tussen de artsen niet altijd als "slecht" kunnen worden gedefinieerd, sluiten de gevonden uitslagen aan bij eerdere publicaties over de tekortkomingen van keuringsuitslagen. Post-Uiterweer en De Kort [i] vonden bij hun panelonderzoek een gemiddelde kappa van 0,35 $\pm 0,07 \mathrm{met}$ een gemiddelde waarde voor PD van $37 \pm 4 \%$. Uit tabel 10 blijkt dat deze waarden in dit onderzoek positiever liggen ten anzien van de kappa, maar dat de waarde van PD met name de A-classificatie die van het onderzoek van Post-Uiterweer en De Kort [1] benadert, ook ten aanzien van de toegekende beperkingen op grond van die A-classificatic.

De overeenkomst tussen de toegekende ABOHZIS-classificatie en de vastgestelde medische beperkingen uit tabel 11 is evenmin zo groot als wenselijk: vaker worden geen medische beperkingen vermeld terwijl toch bij de rubrieken $A, B$ en $O$ een andere score dan 1 wordt vermeld, hetgeen in principe betekent dat beperkingen moeten worden opgelegd. Weliswar is er in alle gevallen sprake van een grote standaardafwijking bij de vermelde kappa, maar gelet op het theoretisch causale verband tussen beide fenomenen mag dit resultaat toch niet als goed worden beschouwd. Ondanks die standaardafwijkingen betekent het voor beoordelaar 3 in twee van de drie classificaties nog steeds een 
wist meer dan redelike owereenstemming. De gevonden $\mathrm{PD}$-warden wan de relatie tussen medische beperkingen en $\mathrm{A}$ - en $\mathrm{O}$-classificatie sluiten, inclusief de standaatdafwijkingen, gehe a an bij de bevindingen van Post-Uiterweer en De Kort [1].

De stapel dossiers waarut de aselecte trekking platsvond, kwam tot stand ondat militairen periodiek worden herkeurd. Vanaf hun aanstelling dienen zij vijfaarlijks opnieuw te worden gekeurd. Het moment van aanstelling is dus bepalend voor het feit dat deze bewuste dossiers op de stapel lagen. Het gaat daarbij om alle militairen die viff jar daarvoor (of een veelvoud daarvan) zijn opgekomen. Er is echter geen aanleiding om te veronderstellen dat deze militairen een afwijkend patroon in ziekten of gebreken zouden hebben ten opzichte van andere militairen die reeds voordien waren gekeurd of nog gekeurd moesten worden. In dat opzicht zou er wel sprake kunnen zijn van selectiebias, maar die bias zou geen invloed uitoefenen op bet resultat.

Het verschil in ervaring tussen beide beoordelaars wordt in theorie opgeheven door de uitvoerige werkinstructies inzake het toekennen van de ABOHZIS-classificatie en de bijbehorende beperkingen (paragrafen $1.3 .1 \mathrm{en}$ 2.2).

De oorspronkelijke beoordelaar heeft de militair in persoon gezien. Beoordelaar 2 en 3 hebben dat niet; hun oordeel komt tot stand op basis van alleen schriftelijke informatie. Door het overnemen van alle informatie uit de dossiers is getracht om het beeld woor deze artsen te completeren, maar daarmee wordt de fysieke afwezigheid (non-verbale en verbale communicatie) niet bestreden. Dit probleem heeft zich echter evenzeer bij het voor deze studie als voorbeeld geldend onderzoek van Post-Uiterweer en De Kort [1] voorgedaan. Deze onderzoksmethode wordt vaker gehanteerd on de mate van overeenstemming vast te stellen. Bovendien zijn keurend artsen bij de KL door de gehanteerde werkwijze (overname van informatie wit het meegeleverde medisch dossier) woor een gedeelte gewend om zich met schriftelijke gegevens te behelpen.

De artsen zijn het met elkaar eens over de PGO's waar oorspronkelijk geen beperkingen werden vastgesteld. Het feit dat keurend artsen onderling weinig beoordelingsverschillen vertonen indien zij een militair zonder ziekten of gebreken keuren, zal weinig verbazing wekken. De onderlinge verschillen nemen echter toe narmate de medische problematiek groter wordt - en derhalve ook de meegeleverde correspondentie toeneemt. Dit duidt eerder op verschillen in interpretatie dan op verschillen op grond van informatie-bias.

Een ander effect dat kan zijn opgetreden, omdat de eerste keurend arts de gekeurde wel en de twee andere niet hebben gezien, is het Hawthorne-effect 
ten opzichte van de eerste keurend arts. Deze zou door de onderzoekspersoon ten anzien van de conclusies kunnen zijn gemanipuleerd. Van de andere twee artsen valt niet uit te sluiten dat zij zich sociaalwenselijk hebben opgesteld ("misschien verwacht de onderzoeker wel dat wij tot dezelfde conclusies komen"). De invloed van beide effecten valt niet te meten; aangenomen wordt dat die invloed beperkt is geweest.

De verdeling van zowel de afwijkende bevindingen (in ABHOHZIS-classificaties) als de mate ervan $(1,2$ of $x)$ en de daaraan gekoppelde beperkingen correspondeert goed met de resultaten van het loopbaanonderzoek onder 13.500 militairen in 1994 [10], waaraan onder de inleiding werd gerefereerd.

De ABOHZIS-classificatie wordt in theorie aangevuld met de "Aanwijzingen", hetgeen ertoe zou moeten leiden dat bij soortgelijke keuringsbevindingen telkens eenzelfde ABOHZIS-classificatie wordt opgemaakt. Soortgelijke "Aanwijzingen" bestaan niet voor het waarborgen dat bij dezelfde ziekten of gebreken ook telkens dezelfde beperkingen worden vastgesteld. Toch is bij de vaststelling van medische beperkingen de overeenstemming tussen de artsen vergelijkbaar met die bij de vaststelling van de ABOHZIS-classificatie. Dat sluit aan bij de conclusie van De Kort [2] dat meer gedetailleerde instructie slechts geringe invloed heeft op de mate van overeenstemming.

In tegenstelling tot de geringe praktische betekenis van de ABOHZIS-classificatie (er wordt op geen enkele wijze door de KL-organisatie van de ABOHZIS-classificaties van PGO-keuringen gebruik gemaakt) wordt door de $\mathrm{KL}$ wel grote betekenis toegekend aan de medische beperkingen. Zij vormen de basis voor de op te stellen functioneringsbeperkingen en kunnen aanleiding zijn om een militair geen nieuwe functie toe te wijzen, met als gevolg dat de betrokken militair sterk gereduceerde kansen heeft op behoud van zijn werk.

Men zou bezwaar tegen dit gehele hoofdstuk kunnen maken, ondat hier de reproduceerbaarheid is onderzocht van een keuringssysteem, dat momentee] niet langer in gebruik is. In de inleiding is reeds angegeven dat het als de publicatie van een niet-systematische waarneming moet worden beschouwd Het motief voor volledige weergave ervan in dit proefschrift is dat dit de eerste schrede op weg naar meer onderzoek was; zonder dit onderzoek zouden de overige hoofdstukken en publicaties nimmer zijn verschenen

Tijdens dit onderzoek zijn vragen gerezen inzake de aard en inhoud van de gehanteerde lijst met medische beperkingen. Gezien de warde die de KL eraan hecht lijkt het van het hoogste belang om juist het gebruik hiervan te protocolleren. Gelet op het teleurstellende resultaat van het protocolleren wan de ABOHZIS-classificatie (die immers geen betere overeenstemming oplevert dan 
de ongeprotocolleerde nedische beperkingen) heeft een dergelijke protocollering alleen zin indien die medische beperkingen functie(groep)-gericht zijn en kunnen worden afgezet tegenover functie-eisen.

Op grond van het bovenstaande wordt geconcludeerd dat de ABOHZIS-systeinatiek, waarvan de nadelen al langer bekend waren, zelfs met behulp van de "aanwijzingen" niet langer aan de huidige behoeften voldoet.

\section{Geraadpleegde literatuur}

1. Kort WLAM, Post-Uiterweer HW: Project anstellingskeuringen dossieronderzoek bij de RBB. Deel 11: panclonderzoek. Ministerie van Sociale Zaken en Werkgelegenheid, S 53-2, 1991.

2. Kort WLAM de: Personnel selection through prememploynent medicals. Ansterdam, 1993.

3. Belloni R: De bepaling van de dienstgeschiktheid. Utrecht, 1985.

4. Bakker LF: Militaire keuringen en het ABOHZIS-systeem. Nederl Mil Geneesk T 1972, 25: 284-290.

5. Kessel JGFM wan: Consequenties van onjuist keuren. Ned Mil Geneesk T; 1984 (37): $176-228$.

6. Tafels Wiskunde Statistiek. Groningen: Wolters-Noordhoff, 1973.

7. Bouter LM, Dongen MCJM van: Epidemiologisch onderzoek, opzet an interpreatie. Houten: Bohn, Stafleu en van Loghum 1995.

8. Schouten HJA: Nomimal scale agreement among observers. Psychometrika 1986;51; 3 : 453-466.

9. Schouten HJA: Klinische statistiek. Houten: Bohn Stafleu Van Loghum, 1995.

10. Raad J de, Blankestijn CDA: Loopbaanprognose bij de Koninklijke Landmacht: medische beperkingen. Carré1995; 7/8:10-13,9:14-16,10:20-24. 
3 | Een onderzoek naar de reproduceerbaarheid van de basismedische eisen KL bij de pensioenkeuring

In belangrijke mate gebaseerd op: Raad J. de, Peters JHM., Nijhuis FJN:

De kwaliteit van een keuringssysteem. TBV 2000; 8:105-109. 


\subsection{Inleiding en vraagstelling van het onderzoek}

In november 1988 is bij de Koninklijke Landmacht (KL) een nieuw keuringssysteem ingevoerd. Dit systeem bestat uit 43 beoordelingspunten, waarbij aan elk beoordelingspunt een minimaal te behalen waarde is toegekend: de Basismedische Eis KL (BMEKL). Deze Basismedische Eisen vormen de operationalisatie van de door de Bevelhebber der Landstrijdkrachten - de werkgever - van kracht verklaarde "basiseisen ten behoeve van militair KL-personeel" ("militaire basiseisen"). Bij het opstellen van de Basismedische Eisen is gebruik gemaakt van zowe] het belastbaarheidspatroon van het Functie Informatie Systeem (FIS) als van een aantal specifieke militaire beoordelingspunten[1]. De intentie bij het operationaliseren was om volgens het principe van "belasting-belastbaarheid" [2] op medisch gebied vorm te geven aan de taakstelling van de militair ambtenaar zoals verwoord in de Wet op de Medische Keuringen. Dit keuringssysteem verving het tot dan toe in gebruilk zijnde diagnose-gerelateerde zogeheten ABOHZIS systeem.

Inmiddels had onderzoek van onder meer De Kort [3] aangetoond dat op aanstellingskeuringen in het algemeen de nodige kritiek viel te leveren. Vervolgens had Reulings [4] de mate van overeenstemming van de diagnose-gerelateerde ABOHZIS-keuringen binnen de KL in het bijzonder onderzocht. Die mate van overeenstemming bleek overeen te komen met de (teleurstellende) resultaten van het onderzoek van De Kort [3].

$\mathrm{Na}$ ingebruikneming van het nieuwe BMEKL-keuringssysteem rees dan ook de vraag of dit systeem wél tot voldoende overeenstemming zou leiden. Bij het beantwoorden van die vraag moest rekening worden gehouden met het feit dat dit keuringssysteem niet alleen wordt grebruikt voor de medische aanstellingskeuring, maar ook voor het medisch afkeuren van (post-)actief dienend personeel: de pensioenkeuring.

Elke KL-militair dient "algemeen en breed inzetbatar en uitzendbaar" te zijn. Daarom wordt niet alleen het ziekteverzuim geregistreerd, maar ook andere vormen van arbeidsverzuim (chronische blessures e.d.), die de operationele inzetbaarheid verminderen. Indien de operationele inzetbaarheid door een vorm van verzuim langdurig wordt angetast, ongeacht de mate waarin de vredesfunctie wordt uitgevoerd, kan de werkgever de militair in kwestie voor een pensioenkeuring laten oproepen. Op het terrein van de sociale wetgeving is voor militairen naast de Ziektewet $(Z W)$ en de Wet op de Arbeidsongeschiktheid (WAO) ook het "Kaderbesluit Militaire Pensioenen" van toepassing. De daarbij behorende pensioenkeuring - beoordeling van dienstgeschiktheid en het recht op dienstverbanduitkeringen - vindt plaats bij de Verzekeringsgeneeskundige Dienst KL (VGDKL), in commissoriaal verband. 
Bij dit onderzoek is de mate van overeenstemming van het nieuwe keuringsisysteem bij de pensioenkeuning onderzocht. De vragstelling voor dit onderzoek luidde: "Voldoet de reproduceerbararheid van het niemwe keuringsysteem by de pensioenkeuring aan de normering die gebruikelijk is voor screeningstesten?"

\subsection{Materiaal en methoden}

\subsubsection{Populatie en procedure}

Er is voor gekozen om gebruik te maken van keuringsdossiers van militairen die een pensioenkeuring (Militair Geneeskundig Onderzoek, MGO) hebben ondergaan. Deze MGO's waren door een commissie van drie verzekeringsartsen nog beoordeeld volgens de oude systematiek van de ABOILZIS-classifcatie. Om die reden kon de oorspronkelijke uitslag niet in dit onderzoek worden meegenomen.

De meerderheid van de voor een pensioenkeuring in anmerking komende millitairen wordt afgekeurd. Om inzicht te krijgen in de overeenstemming van zowel geschikt als ongeschikt verklaarden is een gelede steekproef genomen van de circa 400 dossiers van het afgelopen jaar. Zowel de geschikt verklaarden als de ongeschikt verklaarden werden apart genummerd, watma een medewerker tweemaal vijftien toevalsgetallen uitkoos. De dossiers zijn geanonimiseerd en de conclusies zijn verwijderd (figuur 12).

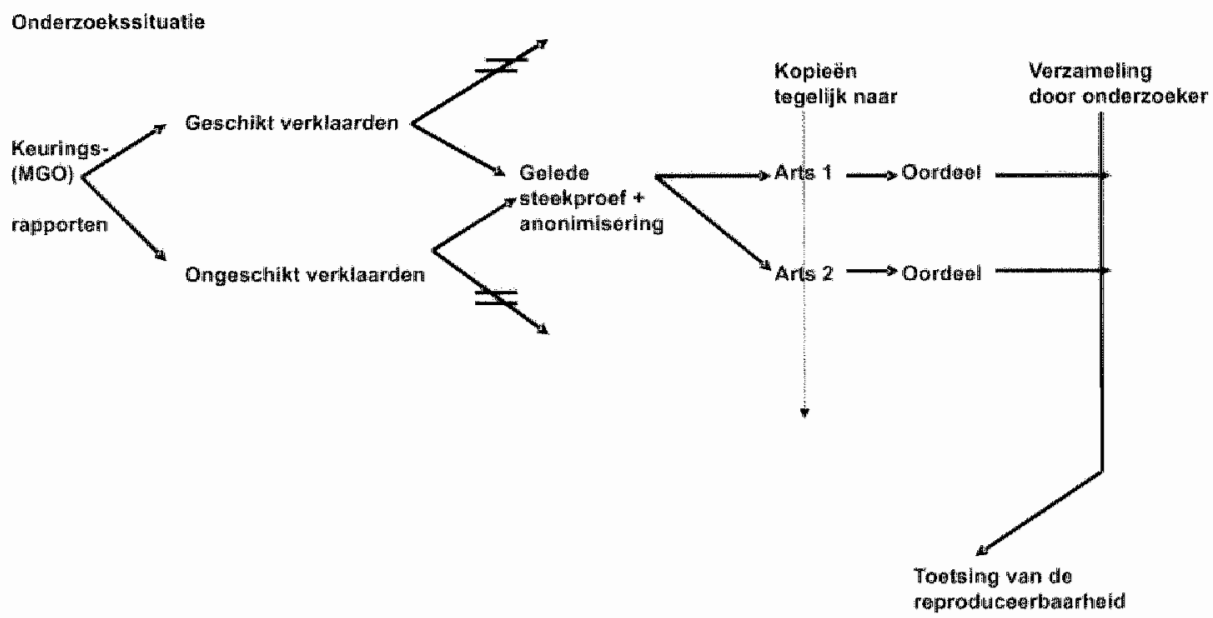

Figutar 12: De onderzoeksopzet wan hoofdstuk 3.

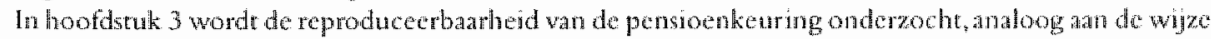
watrop dat in Figum 5 voor het periodiek geneeskundig onderzoek heeft platrgewonden. 
Deze keurngsdossiers zin vervolgens voorgelegd an twee seniorbedrijfartsen wan de Arbo-dienst $\mathbb{K L}$ met langdurige keuringservaring, met het verzoek om volgens de nieuwe keuringmethode tot en endoordeel te komen over de militaire dienstgeschik heid.

De betrokken artsen hadden nog weinig praktijkervaring met het nieuwe keuringsysteem. Een van hen had aan de totstandkoming van de basismedische eisen KL meegewerkt. Ter reductie van eventuele bias is hun kennis voorafgande het onderzoek op hetzelfde peil gebracht.

De artsen moesten een eindoordeel vellen inzake de dienst(on-)geschiktheid. Dit oordeel kont tot stand doordat de bedrijfsarts beoordeelt of de betrokken militair al dan niet voldoet aan de Basismedische Eis van elk van de 43 beoordelingspunten. Die Basismedische Eis ligt op het prestatieniveat waardoor de geschikt verklaarde militair in staat moet worden geacht om het grootste deel van de beschikbare arbeid in ons land zonder beperkingen te kunnen verrichten. Dit betekent dat voor alle beoordelingspunten een dichotome beslissing wordt gevraagd: men is wel of niet geschikt.

\subsubsection{Statistische methoden}

Voor dit onderzoek worden twee maten van overeenstemming gebruikt: de kappa [5] en het percentage discordante of discongruente uitslagen (PD): (GO $+O G / G G+G O+O G+O O) \times 100 \%$. De warde van kappa $\left(P_{0}-P_{e} / 1-P_{e:}\right.$ hierbij staat $\mathrm{P}_{0}$ voor de waargenomen overeenstemming en $\mathrm{P}_{\mathrm{e}}$ voor de toevallige overeenstemming) varieert tussen 0 en 1. Volgens Bouter en Van Dongen [6] suggereren gepubliceerde onderzoeksgegevens dat een kappa tussen de 0,40 en 0,75 voor diagnostische testen in de kliniek gebruikelijk is. Regelmatig wordt bij de interpretatie van warden van kappa een onderverdelling gehan teerd. Daarbij zou een kappa $<0,40$ betekenen dat de mate van overeenstemming gering is, een kappa tussen 0,40 en 0,60 dat de mate van overeenstemming redelijk is, een kappa tussen 0,60 en 0,75 dat de mate van overeenstemming goed is en een kappa van meer dan 0,75 dat de mate van overeenstemming voortreftelijk is. De kappa is afhankelijk van een antal factoren, zoals het aantal beoondelingscategorieèn (strata): hoe meer strata des te kleiner de kappa [6]. Voorts is de kappa afhankelijk van de te verwachten prevalentie wan elk van de beoordelingsuitkomsten $[6,7,8]$. Als een andoening zeldzaam is zal de kappa laag blijven, ook bij een hoge mate van overeenstemming $[7,8]$. Bij het berekenen van de kappa wordt telkens ook het 95\%-betrouwbaarheidsinterval weergegeven [8]. 


\subsection{Resultaten}

De resultaten wan zowel de afzonderlijke beoordelingspunten als het integrale eindoordeel worden in onderstaande tabellen weergegeven. In tabel 13 wordt de mate van overeenstemming van de beoordelingspunten van het bewegingsapparaat weergegeven. Van de 16 beoordelingspunten van tabel 13 vertonen 6 goede overeenstemming, 6 een redelijke en 4 een geringe overeenstemming. Het percentage discongruente uitslagen varieert tussen de $3,3 \%$ en $30,0 \%$.

Tabel 13. De overenstemming pet beordelingspunt (FIS- bexegingsapparat") ungedrukt in de kappa, het 95\%metroumbarheidsinterval en het percentage discongruente antwoorden PD tussen beide artsen.

\begin{tabular}{|c|c|c|c|c|c|}
\hline $\mathrm{Nr}$ & Beoordelingspunt & Kappa & $\begin{array}{l}95 \% \text { Betrousbaar- } \\
\text { heidsinterwal }\end{array}$ & Overecnstemming & PDW \\
\hline 1 & Zitten & 0,29 & $-0.18-0.76$ & Gerings & 13,3 \\
\hline 2 & Stan & 0,76 & $0.50-1.02$ & Goed & 10,0 \\
\hline 3 & Lopen & 0,32 & $0.02-0.62$ & Gering & 26,7 \\
\hline 4 & Trappenlopen & 0,22 & $-0.06-0.48$ & Gering & 30,0 \\
\hline 5 & Klimmen en kllauteren & 0,42 & $0.11-0.73$ & Redelijk & 23,3 \\
\hline 6 & $\begin{array}{l}\text { Knielen, kruipen, en } \\
\text { hurken }\end{array}$ & 0,34 & $0.06-0.62$ & Gering & 23,3 \\
\hline 7 & Gebogen werken & 0,47 & $0.10-0.84$ & Redelijk & 16,7 \\
\hline 8 & $\begin{array}{l}\text { Kortcyclisch buigen en } \\
\text { torderen }\end{array}$ & 0,41 & $0.05-0.77$ & Redelijk. & 20,0 \\
\hline 9 & Gebruik van de nek & 0,53 & $0.07-0.99$ & Redelijk & 10,0 \\
\hline 10 & Reiken & 0,62 & $0.23-0.91$ & Goed & 10,0 \\
\hline 11 & Bowenhands werken & 0,67 & $0.33-1.01$ & Gocd & 10,0 \\
\hline 12 & Hand- en vingergebruik & 0,78 & $0.36-1.20$ & Goed & 3,3 \\
\hline 13 & Tillen & 0,68 & $0.39-0.97$ & Gocd & 113,3 \\
\hline 14 & Duwen en trekkin & 0,55 & $0.25-0.85$ & Redelijk & 20,0 \\
\hline 15 & Dragen & 0.71 & $0.45-0.97$ & Goed & 13,3 \\
\hline 24 & Vibratiebelasting & 0,41 & 0.060 .76 & Redolijk & 10,0 \\
\hline
\end{tabular}


Tabel 114. De mate wan overeenteminting per beoordelingspunt (FIS-Psychische belasting) uitgedrukt in de kappa, het $95 \%$-betrouwbarheidsinterval en her percentuge discongruente antwoorden PD twsen beide artsers:

\begin{tabular}{|c|c|c|c|c|c|}
\hline $\mathrm{N} r$ & Beoorddingspunt & Kappa & $\begin{array}{l}95 \% \text { Betrotw war- } \\
\text { heidsinterval }\end{array}$ & Overeenstemming & PDir \\
\hline 27 & Persoonlijk risico & 0,13 & $-0.14-0.40$ & Gering & 36.7 \\
\hline 28 & Psychtsche butasting & 0,60 & $0.28-0.92$ & Goed & 16.7 \\
\hline $28 \mathrm{~A}$ & Werken onder tijdidruk & 0,51 & $0.14-0.88$ & Radelijk & 16.7 \\
\hline 283 & Dwingend werktempo & 0,23 & $-0.18-0.64$ & Gering & 23,3 \\
\hline $28 \mathrm{C}$ & Gedwongen nietsdoen & 0,28 & $-0.25-0.79$ & Gering & 13,3 \\
\hline 280 & $\begin{array}{l}\text { Conflickerende } \\
\text { functie-eisen }\end{array}$ & 0,78 & $0.5 t-1.07$ & Goed & 6,7 \\
\hline $28 \mathrm{E}$ & Conflicthanterings & 0,45 & $0.25-0.85$ & Redelijk & 16,7 \\
\hline $28 \mathrm{~F}^{2}$ & $\begin{array}{l}\text { Verrichten monotoon } \\
\text { werk }\end{array}$ & 0,06 & $-0.38-0.46$ & Gering & 13,3 \\
\hline $28 \mathrm{G}$ & $\begin{array}{l}\text { Contack/ongang met } \\
\text { anderen }\end{array}$ & 0.35 & $-0.23-0.93$ & Gering & 10,0 \\
\hline $28 \mathrm{H}$ & Verantwoordelijkheid & 0,71 & $0.44-1.08$ & Goed & 6.7 \\
\hline $28 \mathrm{~T}$ & Ongeving en Jawai & 0,59 & $0.24-0.94$ & Redelijk & 16,7 \\
\hline 281 & $\begin{array}{l}\text { Geen mogelijkhaid tot } \\
\text { contact }\end{array}$ & 0,63 & $0.15-0.87$ & Goed & 6,7 \\
\hline $28 \mathrm{~K}$ & Enotionele bellasting & 0,67 & $0.32-1.02$ & Goed & 10,0 \\
\hline $28 \mathrm{~L}$ & Paychiarrische stoornisen & 0,45 & $0.05-0.85$ & Redelijk & 16,7 \\
\hline $28 M$ & $\begin{array}{l}\text { Operationele inzet } \\
\text { mogelijk }\end{array}$ & 0,52 & $0.24-0.80$ & Redelijk & 23,0 \\
\hline $28 \mathrm{~N}$ & Verslawing & 1,0 & & Voortreffelijk & 0,0 \\
\hline
\end{tabular}

Tabel 14 toont de mate van overeenstemming van de beoordelingspunten van de psychische belasting. Van de 16 beoordelingspunten vertoont 1 een voortreffelijke overeenstemming; 5 vertonen goede overeenstemming, 5 een redelijke en 5 een geringe overeenstemming. De PD varieert tussen de 0,0 en $36,7 \%$. Tabel 15 lat de mate van overeenstemming zien van de van de "militaire" beoordelingspunten. Van de 11 beoordelingspunten vertonen 2 een voortreffelijke overeenstemming; 3 vertonen een goede overeenstemming, 3 een redelijke en 3 een geringe overeenstemming. De PD varieert tussen de 0,0 en $30,0 \%$. Van een aantal punten ( 16 tot en met $23,25,26,34,35,36,42)$ kon de kappa niet worden berekend omdat temminste één van beide artsen uitsluitend positieve ("Voldoet aan de gestelde eis") uitslagen versterkte. Als gevolg daarvan is de wargenomen overeenstemming $\left(\mathrm{P}_{\mathrm{o}}\right)$ minus de toevallige overeenstemming 


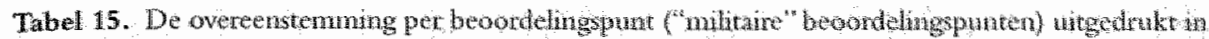
de kappa, het 95\%-betrouwbaaheidsinterval en het percentage discongraente antwoorden PD tusisen beide artsen.

\begin{tabular}{|c|c|c|c|c|c|}
\hline $\mathrm{Nr}$ & Beoordelingspunt & Kappa & $\begin{array}{l}95 \% \text { Betroumbar- } \\
\text { heidsinterten }\end{array}$ & Overeenstennming & Prow \\
\hline 29 & Algemene conditie & 0,78 & $0.55-1.01$ & Goed & 10,0 \\
\hline 30 & Lopen met bepakking & 0,86 & $0.66-1.06$ & Voomentijg & $a_{2} ?$ \\
\hline 31 & Graven & 0,55 & $0.55-1.01$ & Redelijk. & 10,0 \\
\hline 32 & Springen & 0,36 & $0.04-0.68$ & Gering: & 23,3 \\
\hline 33 & Optreden te volde & 0,37 & $0.10-0.64$ & Gering: & 30,0 \\
\hline 37 & Gesaneerd gebit & 1,0 & & Vontrefelijk & 0,0 \\
\hline 38 & Scherfwerend vest dragen & 0,46 & $0.16-0.76$ & Redeligk & 23,3 \\
\hline 39 & Heln dragen & 0,71 & $0.43-1.09$ & Goed & 6.7 \\
\hline 40 & Hanteren wurwapen & 0,78 & $0.51-1.07$ & Goed & 6,7 \\
\hline 41 & Onregelmatig functioneren & 0,30 & $0.04-0.66$ & Gering & 33,3 \\
\hline 43 & Geneesmiddel athankelijkheid & 0,54 & $0.14-0.74$ & Redelijk & 13,3 \\
\hline
\end{tabular}

Tabel 16. Het percentage discongruente antwoorden PD tussen beide artsen woor die beoordelingspunten, warwan de kappa niet kan worden berekend.

\begin{tabular}{lll}
\hline $\mathrm{Nr}$ & Beoordelingspunt & PD\% \\
\hline 16 & Luchtverplatsing & 10,0 \\
17 & Stof rook gas en damp & 0,0 \\
18 & Koude-tolerantic & 13,3 \\
19 & Wratmte-tolerantic & 6,7 \\
20 & Tenuperatumswisselingen & 13,3 \\
21 & Luchtverplating & 10,0 \\
22 & Droge luche & 3,3 \\
23 & Hundcontact & 0,0 \\
25 & Gebruik wan de zintuigen & 0,0 \\
26 & Beschernende middelen & 3,3 \\
34 & NBC-bescherming & 16,7 \\
35 & Tropische onstandigheden & 0,0 \\
36 & Spreekwaardigheid & 3,3 \\
42 & Verdragen dagelijkse voeding & 3,3 \\
\hline
\end{tabular}


(Pd) gelijk aan nuil, zodat de waarde van kappa (zajnde $\mathrm{P}_{0}-\mathrm{P}_{\mathrm{e}} / 1-\mathrm{P}_{k}$ ) niet kan worden berekend. Van deze punten is alleen het percentage discongruente antwoorden berekend en in tabel 16 weergegeven.

In figur 13 wordt de mate van overeenstenming inzake het eindoordeel weergegeven. De kappa bedraagt 0,74 en de $\mathrm{PD}$ is $13,3 \%$.

Eindoorded dientgeschikthen Kappa $=0,74(0.48-0.98)$

Interpretatio owerententhing goed. PD: $13,3 \%$

Figaur 13. Eindoordacl dientgeschiktheid, uitgedruke in kappa en PD.

\subsection{Beschouwing}

Het uiteindelijke doel van de ontwikkeling van de Basismedische Eisen was om te kunnen keuren, gericht op de aard van de werkelijke militaire activiteiten, inclusief het operationeel optreden. Dit functiegerichte keuren dient tenminste gepaard te gaan met een anvaardbare mate van onderlinge overeenstemming. Alhoewel de validiteit van het keuringssysteem hiermee nog niet is onderzocht, is goede reproduceerbaarheid een vereiste voorwaarde voor een voldoende mate van validiteit [6].

Kijkend naar de kappa kan worden gesteld dat de mate van overeenstemming voor wat betreft het eindoordeel van de dienstgeschiktheid goed is. Voor een belangrijk deel van de separate Basismedische Eisen is de overeenstemming redelijk tot zelfs hoog te noemen. Dit geldt zowel ten aanzien van de FIS-gedeelten van de Basismedische Eisen inzake het bewegingsapparaat en de psychische belasting, als ten aanzien van de specifiek militaire Basismedische Eisen.

Ten aanzien van de percentages discordante uitslagen wordt de vergelijking getrokken met de uitkomsten van De Kort [3] bij het panelonderzoek onder RBBB-artsen. Helemaal eerlijk is die vergelijking overigens niet, want bij het gememoreerde panelonderzoek waren vijf artsen betrokken en niet zoals hier slechts twee, waardoor de kans op onderlinge spreiding van de resultaten in dit onderzoek geringer is. De PD scores uit dit onderzoek moeten dan ook eerder als indicatief worden beschouwd. In het onderzoek onder de RBB-artsen werd een gemiddelde PD-waarde van $37 \pm 4 \%$ gevonden. In dit onderzoek liggen de PD-waarden voor 41 van de 43 beoordelingspunten alsmede het eindoordeel beduidend lager dan in dat van De Kort [3]. Alleen voor de beoordelingspunten, 27 (persoonlijk risico) en 42 (onregelmatig functioneren) is de score vergelijkbaar. 
De beoordelingspunten kunnen globaal in drie gedeelten worden onderscheiden, zoals de tabellen aangeven: een cluster "FIS-bewegingsapparate", een cluster psychische belastbaarheid uitgedrukt in de punten 27 en 28 en een cluster met specifiek militaire eisen. Bij 29 van de 43 Basismedische Eisen (67\%) kan een uitspraak worden gedaan geven over de mate van overeenstemming met behulp van de kappa. Daaronder is bij $75 \%$ van de beoordelingspunten sprake van een redelijke of hogere mate van overeenstemming.

Bij 12 beoordelingspunten is de mate van overeenstemining gering (kappa < 0,40 ). Zoals reeds in paragraaf 3.2.2. werd gesteld, is de waarde van kappa afhankelijk van meerdere factoren, zoals de prevalentie van de bepaalde aandoening $[7,8]$. Als deze bepaalde aandoening weinig voorkomt, dan lopen ook de daaraan gerelateerde beoordelingspunten het risico bij een beoordeling op overeenstemming met behulp van kappa een lage score te vertonen. Gegeven het in dit onderzoek beperkt antal gebruikte dossiers valt niet uit te sluiten dat dit bij deze beoordelingspunten het geval is geweest. Anderzijds kan hier het gebrek aan praktijkervaring een rol hebben gespeeld, maar dit lijkt, gelet op de overige uitkomsten, weinig waarschijnlijk. Tegelijk met de lage waarde van de kappa blijkt bij deze beoordelingspunten de waarde van het percentage discongruente uitslagen niet van die van de overige beoordelingspunten te verschillen. Over het algemeen gaat een lage kappa gepaard met een hoge waarde van PD en omgekeerd. Ook deze bevinding pleit tegen een werkelijk gebrek aan overeenstemming, maar gaat meer in de richting van een lage prevalentie.

Het gebruik van MGO-keuringsdossiers van pensioenkeuringen speelt een soortgelijke rol in de afwezigheid van overeenstemming in de vorm van kappa bij de punten uit tabel 16. Pensioenkeuringen worden alleen uitgevoerd indien men in werkelijke dienst is geweest. Bepaalde aandoeningen - zoals zintuiglijke gebreken of ernstige cariès - zullen al bij de aanstellingskeuringen tot afwijzing leiden. Derhalve komen diverse aandoeningen praktisch niet voor als afkeuringgrond bij de pensioenkeuring. De PD\%-scores uit tabel 15 zijn dan ook relatief laag en variëren tussen de 0,0 en $16,7 \%$. Het feit dat de PD\%-scores niet allemaal nul zijn impliceert overigens dat de artsen daarin toch soms onderlinge verschillen vertonen.

Door de aselecte gelede steekproef is in de sortering van de dossiers selectiebias voorkomen. Het gebruik van zowel dossiers van geschikt als ongeschikt verkJaarden vond opzettelijk plaats, conform het onderzoek van De Kort en Post-Uiterweer [3].

Van de twee nieuwe beoordelaars had er één aan de totstandkoming van het nieuwe keuringssysteem meegeholpen, de andere niet. Zoals reeds is vermeld is 
voorafgande het onderzoek hun kemnis over het nieuwe systeem op hetzelfde niveau gebracht. Het feit dat zij hierna met het nieuwe systeem konden werken sluit aan bij de ervaring die enige tijd later werd opgedaan tijdens de workshops, bedoeld om alle betrokken artsen met het nieuwe systeen te leren werken. Tijdens die bijeenkomsten - afgesloten met een toets - bleek dat alle artsen na afloop ronduit goed met de nieuwe werkwijze overweg konden. Zou bias door een verschil in kennis tussen beide artsen een rol hebben gespeeld, dan zou men bovendien eerder een lagere mate van overeenstemming hebben verwacht. Datarvan is op grond wan de gevonden overeenkomst inzake het eindoordeel tussen beide artsen in dit onderzoek geen sprake.

Het beoordelen van schriftelijke dossiers om de mate van overeenstemming tussen artsen te beoordelen is een hiervoor regelmatig gebruikte methode. In het gebruik van schriftelijke dossiers schuilt mogelijk informatiebias: men keurt immers niet fysick en mist wellicht (non-verbale en verbale communicatieve) signalen. Het voordeel van deze methode is dat de betrokken artsen per definitie uitgaan van dezelfde gegevens. Bovendien vindt de feitelijke pensioenkeuring in commissoriaal verband plaats, waarbij drie artsen betrokken zijn. Dit betekent niet dat de militair in kwestie door drie artsen wordt onderzocht, maar dat het door één arts opgestelde keuringsdossier door twee andere artsen wordt doorgenomen en (al dan niet) wordt onderschreven. Het is voor artsen bij de KL derhalve niet ongebruikelijk om een beoordeling te verrichten met behulp van alleen het dossier. Op grond hiervan wordt aangenomen dat informatiebias de onderzoeksresultaten niet onaanvaardbaar heeft beïnvloed.

Door het gebruik van dossiers in plats van onderzoekspersonen worden bovendien het Hawthorne-effect [6], het placebo-effect [6] en het Pygmalion-effect $[6]$ wararschijnlijk juist vermeden.

De simenstelling van de dossiers was niet representatief voor de gebruikelije samenstelling van dergelijke dossiers. In de grote meerderheid van de gevallen leidt een pensioenkeuring ook effectief tot afkeuring en niet - zoals hier het geval was - mar in $50 \%$ van de gevallen. De uitkomsten kunnen dus niet eén op Eén van toepassing worden verklaard op de concrete situatie bij de pensioenkeuring. Deze procedure is analoog aan die welke De Kort [3] heeft gebruikt. Wat betreft een aantal individtuele beoordelingspunten heerste bij de beoordeling van de dossiers een hoge mate van overeenstemming over de kwalificatie "betrokkene voldoet aan de Basismedische Eis". Echter, de artsen zijn het nooit met elkaar eens wanneer iemand niet voldoet aan de Basismedische Eis. In die gevallen geldt dat $P_{0}=P_{c}$ en volgt er geen waarde uit de berekening van Kappa. Het ontbreken van deze eensgezindheid, tezamen met een hoge mate van eensgezindheid wanneer er geen sprake is van een beperking, doet evenwel een goede overeenstemming vermoeden. 
De beslissing die de keurend arts in dit kader moest nemen was dichotoom:men is wel of niet geschikt. Schouten [9] stelde dat de waarde van Kappa hoger uitvalt bij een dichotome keuze-mogelijkheid dan wanneer er meerdere keuzemogelijkheden zijn. Dit zou tot een lagere mate van overeenstemming kunnen leiden als er in de toekomst functie-eisen worden ontwikkeld, die hoger liggen dan het niveau van de Basismedische Eisen. Gelet op de te signaleren verschillen in taakstelling tussen de verschillende soorten KL-militairen (zoals bijvoorbeeld het Korps Commando Troepen of het Explosieven Opruimings Commando $\mathrm{KL}$ ), zal het ontwikkelen van meerdere soorten functie-eisen uiteindelijk toch moeten plaatsvinden.

Samengevat kan worden geconcludeerd dat uit dit onderzoek blijkt dat de inter-waarnemer-variatie van het nieuwe keuringssysteem ruimschoots voldoet aan de normering die gebruikelijk is voor screeningstesten. De kappa van het eindoordeel ligt op 0,74 , zodat daarin zelfs sprake is van goede overeenstemming.

Daarbij kunnen de volgende aanbevelingen worden gedaan. In de eerste plats kan in een later stadium nog nader onderzoek worden verricht naar de beoordelingspunten die thans niet met behulp van de kappa te beoordelen waren, respectievelijk een te lage kappa hadden. Dit onderzoek zal vermoedelijk beter bij de aanstellingskeuring kumnen worden verricht.

Voorts zijn de Basismedische Eisen bedoeld als zo goed mogelijke afspiegeling van de concrete militaire (operationele) taakstelling. Indien die taakstelling wordt gewijzigd - bijvoorbeeld als het huidige scherfwerend vest van $15 \mathrm{~kg}$ wordt vervangen door een veel lichter exemplaar of verplaatsing uitsluitend nog gemotoriseerd zou platsvinden - dan dienen die eisen te worden herbezien in het oog van de vermieuwde takstelling.

\section{Geraadpleegde literatuur}

1. Raad J de, Peters JHM, Groor RP de et al: Van diagnose-gerelateed nat functic-gericht keuren. TBV 2000; 8:110-115.

2. Dijk FIH van, Dormolen $M$ van, Kompier MAJ et al: Herwaxdering model belastringbelastbarheid. TSG, 1990;68:3-10.

3. Kort WLAM de: Persomel selection through pre-employment medicals. Ansterdan, 1993.

4. Raad J de, Reulings PGI. Schouten HJA: De beperkingen van medische beperkingen. De reproduceerbarheid van de beoordeling van de ABOHZIS-classificatic en de nedische beperkingen bij periodiek geneeskundig onderzoek bij de Koninklijke Landmacht. Ned Mil Geneesk T; 1996; 49: 106-111.

5. Nijdam B, Butren H. van: Statistiek voor de sociale wetenschap. Alphen and de Rign: Samson. 1979 
6. Bouter MM, Dongen MCJM wan: Epidemiologiseh onderzoek, opzet en interpretatie. Houten: Bohn, Stafleu an van Loghum 1995.

7. Altman DG. Practicall statistics for medical research London: Chapman and Hall, 1991.

8. Stcinjans $V$ W Dilet $\mathrm{E}$, Bönches $\mathrm{B}$ et al Interobserver agreement: Cohens Kappa coefficient does not necessarily teflect the percentage of patients with congruent classifications. Int J of Cin of Pham And Ther. 1997; 35; 3.93-95.

9. Schouten HJA. Nominal scale agrement among observers. Psychometrika 1986; $51 ; 3$ : $453-466$. 


\section{4 | De reproduceerbaarheid van de aanstellingskeuring op grond van de Basismedische eisen en het ABOHZIS-systeem}

In belangrijke mate gebaseerd op: Raad J de, Slootman EJH, Groot RP de: Kwaliteitsverbetering bij de Koninklijke Landmacht. Onderzock naar de kwaliteit van het beoordelen van aanstellingskeuringen woor de Koninklijke Landmacht. TBV 2002; 10: 266-272. 


\subsection{Inleiding en vraagstelling van dit onderzoek}

$\mathrm{Na}$ ingebruikneming wan het nieuwe keuringssysteem van de Basismedische Eisen van de Koninklijke Landmacht (BMEKL) is een onderzoek uitgevoerd met pensioenkeuringen (Hoofdstuk 3). Daaruit bleek dat voor wat betreft het eindoordeel er sprake was van een goede overeenstemming. Daarmee is althans een gedeelte van de vragstelling uit hoofdstuk 1 beantwoord. De BMEKL worden echter niet alleen gehanteerd bij de pensioenkeuring maar ook bij de aanstellingskeuring. Ondat, zoals in de inleiding al is opgemerkt, het keurings-systeem zowel wordt gehanteerd bij de aanstellingskeuring als bij de pensioenkeuring moet ook voor bede situaties de reproduceerbaarheid worden onderzocht. De procedure van de aanstellingskeuring verloopt anders dan die van de pensioenkeuring, daarnaast is sprake van een andere populatie. Bij de pensioenkeuring heeft elke keurling (bepaalde) medische bijzonderheden, vaak leidend tot beperkingen, reden warom de meerderheid van de personen in kwestie wordt afgekeurd. Bij de aanstellingskeuring daarentegen vertoont de meerderheid der kandidaten geen medische bijzonderheden en wordt dan ook geschikt verklaard. Verder wordt de pensioenkeuring altijd voor actief dienend of postactief militair personeel (dat derhalve in het verleden geschikt is verklaard na de aanstellingskeuring) uitgevoerd, terwijl de anstellingskeuring voor nieuw aan te nemen personeel wordt uitgevoerd. Zoals reeds in hoofdstuk 3 is uiteengezet betekent dit dat bepaalde medische bijzonderheden in de praktijk bij actief dienend militair personeel niet voorkomen (zoals ernstige vormen van kleurenblindheid), omdat dit bij de aanstellingskeuring al tot afkeuring leidt. Daarnaast bestaat vermoedelijk ook een leeftijdsverschil tussen het nieuw aan te nemen personeel en met name dat actief dienend personeel dat wordt afgekeurd. Om een completer beeld te krijgen van de reproduceerbaarheid van het nieuwe keuringssysteem volstaat het onderzoek uit het voorgaande hoofdstuk 3 niet en dient daarnaast ook onderzoek te worden verricht naar de mate van overeenstemming bij de aanstellingskeuring.

Zoals in hoofdstuk 1 werd toegelicht kan voor dit onderzoek gebruik worden gemaakt van dezelfde populatie die dient voor de gerandomiseerde, gecontroleerde studie, weergegeven in de hoofdstukken 5,6 en 7 . In de studie van dit hoofdstuk zullen de uitkomsten van twee studiegroepen worden vergeleken, die gerandomiseerd middels het oude (ABOHZIS) ofwel het nieuwe keuringssysteem zijn gekeurd. Hierdoor wordt het mogelijk om de mate van overeenstemming van beide keuringssystemen, zoals zij voor de aanstellingskeuring worden gehanteerd, met elkaar te vergelijken.

De vraagstelling voor dit onderzoek luidt: "Hoe verhoudt zich de mate van overeenstemming tussen beide keuringssystemen bij de aanstellingskeuring?" 


\subsection{Achtergrondinformatie}

Sinds de opschorting van de dienstplicht zijn er twee soorten verbintenissen voor militairen: een beroepscontract van onbepaalde tijd ("BOT") of een beroepscontract van bepaalde tijd ("BBT"), dit latste kent over het algemeen een standaard looptijd van $2^{i / 2}$ jaar. Werving, selectie en de medische aanstellingskeuring vinden central plaats bij het Instituut Keuring en Selectie (IKS) van de krijgsmacht te Amsterdam. Hierbij vinden achtereenvolgens plaats de administratieve selectie (kennis Nederlandse taal, minmaal vereiste opleiding) en de psychologische selectie (capaciteitentest $[1,2]$, respectievelijk een persoonlijkheidsvragentest [3, 4]). Hierna worden de kandidaten voor alle vier de krijgsmachtdelen volstrekt willekeurig ingedeeld voor de medische aanstellingskeuring. Bij die medische aanstellingskeuring speett bij de $\mathrm{KL}$ ook de fysieke selectie een rol.

De medische aanstellingskeuring omvatte ten tijde van deze studie: urineonderzoek, audiometrisch onderzoek naar zowel de lucht-als de beengeleiding van $250 \mathrm{~Hz}$ tot $8 \mathrm{kHz}$, optometrisch onderzoek ter bepaling van de gezichtsscherpte, het stereoscopisch diepte zien en het kleuronderscheidingsvermogen, een rust-ecg (ter preventie van cardiale problemen bij de bepaling van de VO2max), de meting van lichaamsmaten (zoals het vetpercentage), onderzoek naar het bewegingapparaat en de adnexen door de fysiotherapeut, een anamnese en algemeen lichamelijk onderzoek door de keurend arts. De uitslag zelf wordt niet door de keurend arts gegeven, maar door de zogeheten "uitslaggevend arts". Dit is een seniorbedrijfsarts, met langdurige ervaring op het terrein van aanstellingskeuringen. Vooruitlopend op de invoering van het nieuwe keuringssysteem in november 1998, zijn alle betrokken (basis-, bedrijfs- en verzekeringsgeneeskundig) artsen van de KL vooraf bij wijze van introductie in een workshop getraind.

De fysieke selectie vindt plaats met behulp van lichaamsmaten (lichaamsgewicht, vetpercentage met de 4-punts huidplooimeting), maximale kracht (Newtons) en uithoudingsvermogen (Watt/ $\mathrm{kg}$ lichaanngewicht). Op grond hiervan wordt een indeling gemaakt in bepaalde functieclusters van fysicke belastbaarheid.

Tijdens dit onderzoek was de minimumscore van de fysieke selectie "afgesteld" op de $10^{e}$ percentiel van de mannelijke kandidaten, alsmede op de $50^{\circ}$ percentiel van de vrouwelijke kandidaten. Daarmee bleef de ondergrens voor vrouwen in absolute zin lager dan die voor mannen. 


\subsection{Materiaal en methoden}

\subsubsection{Populatie en procedure}

Vanaf 22 september tot en met 16 oktober 1998 - een periode van vier weken zijn 863 kandidaten op de even weken volgens het ABOHZIS-systeem en op de oneven weken volgens de Basismedische Eisen gekeurd. Uit dit onderzoek zijn de 227 als eerste beschikbare keuringsformulieren, afkomstig uit de eerste weken, in drievoud gekopieerd (figuur 14). Vervolgens is aan de oorspronkelijke drie uitslaggevend bedrijfsartsen ongeveer anderhalf jaar later (2000) verzocht om opnieuw uirslag te geven inzake deze keuringen. De oorspronkelijke uitslag wordt hierbij gevormd door de gecombineerde uitslagen van de uitslaggevend artsen in 1998 (Beoordelaar "C").

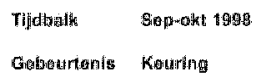

Gobetrtenis Kourthing

\section{Fotm-apt 1999}

Verzameling dessiters anonimiteren
2000

Togtsen owereenstemanimg

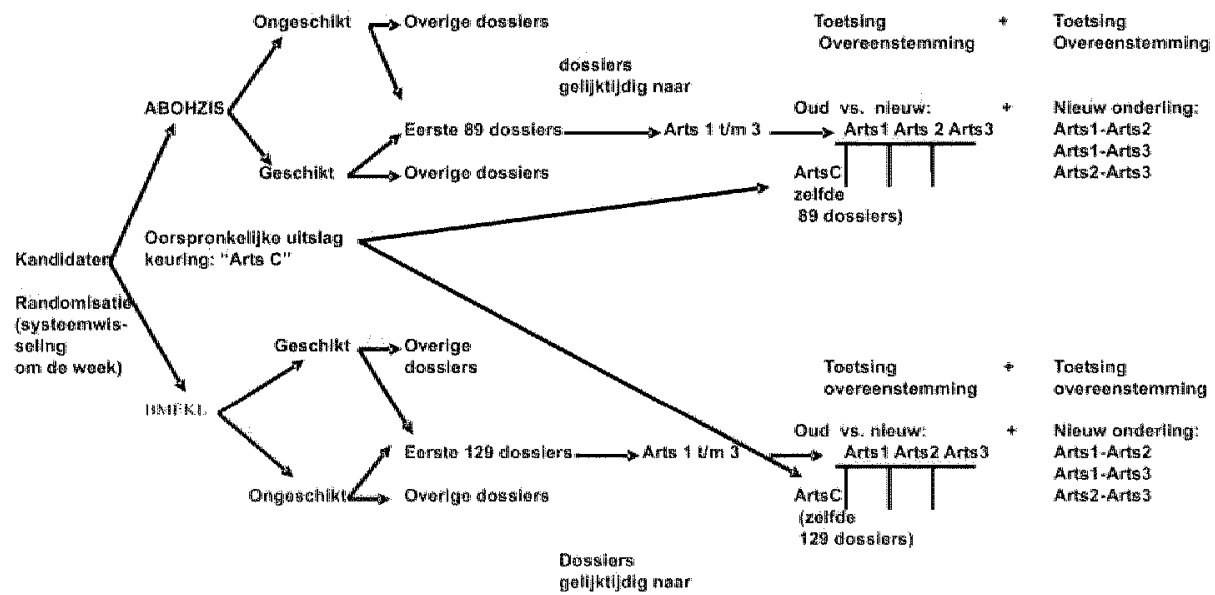

Figutur 14: Do onderzoeksopzer van hoofdetak 4.

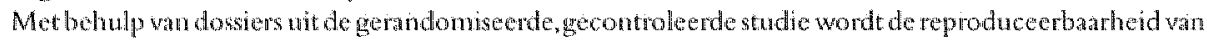

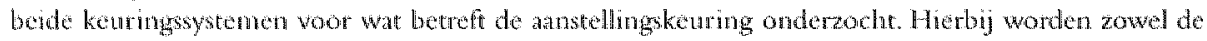
micuwe thitagen onderling vergeleken ("Nienw onderling" dijke uitshg ("Ond verstus nieuw". Arts C versus de Artsen 1, 2 en 3).

\subsubsection{Statistische methoden}

De reproduceerbaarheid kan met behulp van verschillende maten worden onderzocht $[5,6]$, af te leiden van tabel 16 . Teneinde zoveel mogelijk informatie over de mate van overeenstemming te verkrijgen is voor dit onderzoek besloten 


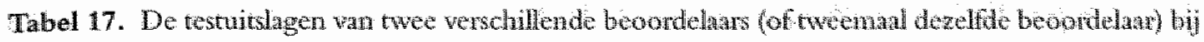
onderzoek in een populatie

Beoondelarar 2

\begin{tabular}{|c|c|c|c|}
\hline & Normale testumblag & $\begin{array}{l}\text { Normale testuitshg } \\
\text { a }\end{array}$ & $\begin{array}{l}\text { Arwikende restuitalag } \\
b\end{array}$ \\
\hline & Afwijkend restuirslag & $\mathrm{c}$ & $d$ \\
\hline
\end{tabular}

om vier verschillende maten te hanteren. Twee maten, de kappa en het percentage discordante uitslagen, zijn reeds in hoofdstuk 2 beschreven. De overige twee te gebruiken maten worden an de hand van tabel 17 beschreven.

Als met beoordelaar 1 en 2 twee verschillende onderzoekers worden bedoeld kan de intra-observers variatie worden berekend. Als met beoordelaar 1 en 2 dezelfde onderzoeker wordt bedoeld kan de intra-observers variatie worden berekend. Hieronder worden de twee nog niet behandelde maten voor overeenstemming weergegeven:

1. Het percentage overeenstemming. Deze mat wordt vooral berekend in geval onderzochte personen op basis van de testuitslag in een beperkt aantal categorieën wordt ingedeeld[5].

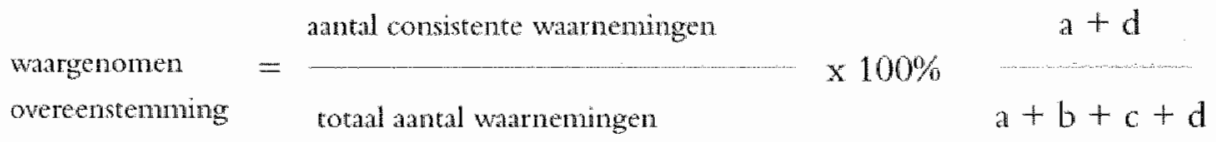

De op deze manier berekende mate van uniformiteit wordt beinvloed door de door elk van de beide warnemers geschatte prevalentie van afwijkende testuitslagen in de onderzochte populatie [5].

2. Men kan ook alleen de testuitslagen vergelijken door de testuitslagen die door één of door beide beoordelatrs als afwijkend zijn bestempeld in de berekening te betrekken. Volgens Bouter en Van Dongen wordt zo een meer realistische inruk van de mate van overeenstemming verkregen[5]:

$$
\frac{\mathrm{d}}{\mathrm{b}+\mathrm{c}+\mathrm{d}} \times 100 \%
$$

De oorspronkelijke testuitslagen zullen tegenover de nieuwe uitslagen van de drie artsen van de beide keuringssystemen worden beoordeeld. Omdat de 
oorspronkelijke testuitslagen zijn verricht door dezelfde artsen die nu bij het onderzoek zijn betrokken, zou op deze manier de intra-waamemers variatie kunnen worden beoordeeld. Helaas waren de dossiers dusdanig geanonimiseerd dat de individuele uitslaggevend arts niet meer te achterhalen viel. Hierdoor kan de intra-warnemers variatie niet worden beoordeeld.

Ook de nieuwe testuitslagen zullen onderling worden vergeleken. Hieruit kan de inter-warnemers variatie worden berekend.

\subsection{Resultaten}

\subsubsection{Uitslagen}

Van de 227 keuringsformulieren bleken 129 volgens het oude systeem (ABOHZIS-classificatie, "Systeem 1"), en 98 volgens het nieuwe systeem. (Basismedische Eisen, "Systeem 2") gekeurd en beoordeeld te zijn. Met behulp van tabel 18 wordt voor de lezer inzichtelijk gemakt hoe de resultaten over beide keuringssystemen verdeeld bleken te zijn.

De percentages ongeschikt verklaarde kandidaten, afkomstig uit beide keuringssystemen $(22 / 129=17 \%$ versus $24 / 83=29 \%)$ verschillen niet statistisch significant $(\mathrm{p}>0.05)$. Het percentage afgekeurde aspirant-militairen, afkomstig van beide keuringssystemen uit dit onderzoek is 20,3 ; dit getal correspondeert met het gemiddelde percentage jarlijkse afkeuringen.

Tabel 18. De verdeling wan het antal keurlingen met en zonder medische beperkingen en de utslag geschikt of ongeschikt over beide keuringsystemen (ABOHZIS en BMEKL).

\begin{tabular}{|c|c|c|c|c|c|c|}
\hline & \multicolumn{3}{|c|}{ ABOHZIS-systeen I ( $n=129)$} & \multicolumn{3}{|c|}{ BMEKL-systectin $2(n=98)$} \\
\hline & $\begin{array}{l}\text { Medische } \\
\text { bijzonderheden }\end{array}$ & $\begin{array}{l}\text { Geen medische } \\
\text { bijzondertheden }\end{array}$ & Total & $\begin{array}{l}\text { Medische } \\
\text { bijzonderheden }\end{array}$ & $\begin{array}{l}\text { Geen medischo } \\
\text { bijzondermeden }\end{array}$ & Total \\
\hline Gerchikt & 60 & 47 & 107 & 59 & 15 & 74 \\
\hline Ongeschikt & 21 & 1 & 22 & 24 & 0 & 24 \\
\hline Total & 81 & 48 & 129 & 83 & 15 & 98 \\
\hline
\end{tabular}

Wat in tabel 18 verder opvalt is dat bij gebruik van het ABOHZIS-keuringssysteem bij minder keurlingen medische bijzonderheden $(81 / 129=63 \%)$ werden vastgelegd dan bij gebruik van het BMEKL-keuringssysteem (83/98=85\%). Bij nadere beschouwing blijkt dit verschil vooral te berusten op het voorkomen van de medische bijzonderheid "onvoldoende fysieke belastbalarheid" (9 van de 129 in geval van het ABOHZIS-keuringssysteem versus 21 van de 98 bij het BMEKL-keuringssysteem). 
Als medische bijzonderheden - en potentiele afkeuringgronden - konen onder de keurlingen uit deze studie de volgende voor:

- onvoldoende fysieke belastbarheid,

- aandoeningen van het bewegingsapparat,

- gehoorbeperkingen,

- afwijkingen aan de visus,

- atopische constitutie.

De medische bijzonderheid "onvoldoende fysieke belastbaarheid" leidt relatief tot de grootste kans op afkeuring, namelijk in 24 van de in totall 30 gevallen warin daarvan sprake is.

Als opmerkelijk feit is er éen kandidat uit het ABOHZ IS-keuringssyteem die geen medische bijzonderheden vertoont, mar die desondanks is afgekeurd. Deze persoon is vervolgens in bezwaar getreden, herkeurd en geschikt bevonden. Ook in de hernieuwde beoordeling wordt deze kandidat telkens als geschikt beschouwd. Hier is sprake van een beoordelingsfout.

\subsubsection{Overeenstemming}

In tabel 19 worden de nieuwe beoordelingen van de drie artsen uit 2000 afgezet tegenover het oorspronkelijke oordeel in 1998. Hierbij is een onderverdeling gemakt tussen het oude en het nieuwe systeem. Vertical worden de te onderscheiden fracties weergegeven (GG, OO, GO en OG of a, d, b en c). Daarbij is de congruente fractie waarbij beide oordelen eensluidend zijn over de geschiktheid aangegeven als GG, respectievelijk a ; de congruente fractie warbij beide oordelen eensluidend zijn over de ongeschiktheid zijn aangegeven als $\mathrm{OO}$, respectievelijk d; de discongruente fracties - er is geen overeenstemming - zijn achtereenvolgens angeduid als $O G$, respectievelijk $c$ (het oorspronkelijke geschiktheidoordeel wordt achteraf veranderd in ongeschiktverklaring) en $6 \mathrm{O}$, respectievelijk b (het oorspronkelijke ongeschiktheidoondeel wordt achteraf veranderd in geschiktverklaring). Daaronder worden de bij dit onderzoek gehanteende maten voor overeenstemming weergegeven, met de gemiddeldes en standardafwijkingen.

De 95\%-betrouwbarheidsintervallen van alle vermelle kappa's overlappen elkaar ruimschoots. Op grond van de onderlinge gemiddeldes en de darbij vermelde standaardafwijkingen kan eveneens worden gezien dat de overige maten van overeenstemming onderling geen statistisch significante verschillen vertonen.

Opvallend is voorts het feit dat men veel minder afwijkt van het oorspronkelijke ongeschiktlieidoordee $O G$ (c) dan andersom $G O$ (b).

In tabel 20 zijn de onderlinge uitslagen tussen de drie nitslaggevend seniorbedrijfsartsen zoals ze in 2000 beoordeelden, op dezelfde manier weergegeven 
Tabel 19. De vergelijking tuswen de gecombineerde uitslagen van de uitslaggevend artsen ün 1998 (Beoordetar " $\mathrm{C}$ ) en de in 2000 werkregen uivilagen van de afzonderlijke uitslaggevend artsen (artsern 1,2 en 3 ).

\begin{tabular}{|c|c|c|c|c|c|c|c|c|c|c|}
\hline \multirow[b]{2}{*}{ Uithagen } & \multicolumn{5}{|c|}{ ABOHZIS-yysteen 1. $(n=129)$} & \multicolumn{5}{|c|}{ BMEKL-systeem $2(\mathrm{n}=98)$} \\
\hline & $\begin{array}{l}\text { Cus } \\
\text { Arsil }\end{array}$ & $\begin{array}{l}C \\
\text { Arts } 2\end{array}$ & $\begin{array}{l}\text { Cvs. } \\
\text { Arrs3 }\end{array}$ & GEM & $\mathrm{SD}$ & $\begin{array}{l}\text { Cvs. } \\
\text { Arts } 1\end{array}$ & $\begin{array}{l}\mathrm{C} \text { ws. } \\
\text { Art:2 }\end{array}$ & $\begin{array}{l}\text { Cws. } \\
\text { Arts3 }\end{array}$ & $\mathrm{GEM}$ & $\mathrm{SD}$ \\
\hline $\operatorname{CG}(a)$ & 95 & 97 & 96 & & & 67 & 67 & 69 & & \\
\hline 60 (b) & 12 & 10 & 11 & & & 7 & 7 & 5 & & \\
\hline OG $(c)$ & 1 & 1 & 5 & & & 1 & 2 & 1 & & \\
\hline$O O(d)$ & 20 & 20 & 17 & & & 23 & 22 & 22 & & \\
\hline \multicolumn{11}{|l|}{ Maten wan } \\
\hline \multicolumn{11}{|l|}{ Overeenstemming } \\
\hline$a+d / a+b+c+d(\%)$ & $90 \%$ & $91 \%$ & $88 \%$ & $90 \%$ & $1,9 \%$ & $92 \%$ & $91 \%$ & $94 \%$ & $92 \%$ & $1,5 \%$ \\
\hline$d / b+c+d(\%)$ & $61 \%$ & $65 \%$ & $52 \%$ & $59 \%$ & $6,7 \%$ & $74 \%$ & $71 \%$ & $79 \%$ & $75 \%$ & $3,8^{\%} \%$ \\
\hline Kappa*y & 0,69 & 0,73 & 0,60 & & & 0,80 & 0.76 & 0.84 & & \\
\hline$b+c / a+b+c+d(\%)$ & $10 \%$ & $9 \%$ & $12 \%$ & $10 \%$ & $1,9 \%$ & $8 \%$ & $9 \%$ & $6 \%$ & $8 \%$ & $1,5 \%$ \\
\hline
\end{tabular}

Tabel 20. De vergelijking tussen de gecombineerde uitslagen van de uitsliaggevend artsen zoals ze in 2000 beoordedden (artsen 1,2 en 3 ).

\begin{tabular}{|c|c|c|c|c|c|c|c|c|c|c|}
\hline \multirow[b]{2}{*}{ Uitslagen } & \multicolumn{5}{|c|}{$A B O H Z I S$-system $1(n=129)$} & \multicolumn{5}{|c|}{ BMEKL systeem $2(n=98)$} \\
\hline & $\begin{array}{l}\text { Arts 1 } \\
\text { vs. } \\
\text { Arts2 }\end{array}$ & $\begin{array}{l}\text { Arts } 1 \\
\text { vis. } \\
\text { Arts } 3\end{array}$ & $\begin{array}{l}\text { Arts2 } \\
\text { vs. } \\
\text { Arts } 3\end{array}$ & GEM & $\mathrm{SD}$ & $\begin{array}{l}\text { Arts1 } \\
\text { ws. } \\
\text { Arts2 }\end{array}$ & $\begin{array}{l}\text { Arts } 1 \\
\text { vg. } \\
\text { Arts3 }\end{array}$ & $\begin{array}{l}\text { Arts2 } \\
\text { ws. } \\
\text { Arts3 }\end{array}$ & GEM & $\mathrm{SD}$ \\
\hline$G G(a)$ & 95 & 94 & 95 & & & 67 & 68 & 68 & & \\
\hline $\mathrm{GO}(b)$ & 1 & 2 & 3 & & & 1 & 0 & $i$ & & \\
\hline OG $(c)$ & 3 & 6 & 5 & & & 2 & 2 & 2 & & \\
\hline $00(d)$ & 29 & 26 & 25 & & & 28 & 27 & 26 & & \\
\hline \multicolumn{11}{|l|}{$\begin{array}{l}\text { Matren var } \\
\text { Overcenstemming }\end{array}$} \\
\hline$a+d / a+b+c+d(\%)$ & $97 \%$ & $94 \%$ & $94 \%$ & $95 \%$ & $1.8 \%$ & $97 \%$ & $98 \%$ & $97 \%$ & $97 \%$ & $0,6 \%$ \\
\hline$d / b+c+d(\%)$ & $88 \%$ & $76 \%$ & $76 \%$ & $80 \%$ & $6,8 \%$ & $90 \%$ & $93 \%$ & $90 \%$ & $91 \%$ & $1,8 \%$ \\
\hline Kappin & 0.92 & 0,83 & 0,82 & & & 0,93 & 0,95 & 0,92 & & \\
\hline$b+c / a+b+c+d(\%)$ & $3 \%$ & $6 \%$ & $6 \%$ & $5 \%$ & $1,8 \%$ & $3 \%$ & $2 \%$ & $3 \%$ & $3 \%$ & $0,6 \%$ \\
\hline
\end{tabular}

O staat voor ongeschikr; $G$ voor geschikt. De uitshgen $G, 00,0 G$ en $G O$ stann voor de uirslagen per arsenpar. GEM stat woor gemiddelde, sd woor standardafwijking. *) De kappa's in het oude en nieuwe keuringssystecm laten poor elk van de artsen geen significante verbetering zien (de 95\%-betrouwbaarheidsintervallen owerlappen elkar ruimschoots\%. 
zoals in tabel 18. Ook hierbij is geen onderscheid te vinden ten alanien de maten van overeenstemming.

Anders dan in tabel 19 is er bij tabel 20 een minder groot verschil tussen de beide discongruente fracties $\mathrm{OG}$ (c) en $\mathrm{GO}$ (b).

De 95\%-betrouwbaarheidsintervallen van alle vermelde kappa's overlappen elkaar wederom ruimschoots. Op grond van de onderlinge gemiddeldes en de daarbij vermelde standaardafwijkingen kan worden aangenomen dat de overige maten van overeenstemming onderling eveneens geen verschillen vertonen.

\subsection{Beschouwing}

Gelet op de kappa kan worden gesteld dat de overeenstemming "in het heden" (tabel 20) voortreffelijk is in het geval van beide systemen. De overeenkomst tussen de momentane uitslagen en die uit het verleden (tabel 19) kan op diezelfde grond als "voortreffelijk" worden gekenschetst. De mate van overeenstemming tussen beide keuringssystemen bij de aanstellingskeuring verschilt niet statistisch significant. De inter-waarnemers variatie is derhalve zeer aanvaardbaar, maar verschilt niet per keuringssysteem.

Idealiter waren alle 863 keuringen bij dit onderzoek betrokken. Door de eerste 227 ( $n>200$ ) keuringsdossiers te gebruiken is een voldoende hoeveelheid verkregen om verantwoorde, gegeneraliseerde uitspraken over te mogen doen. Bij het IKS wordt de uitvoering van de aanstellingskeuring voor kandidaten van de vier verschillende krijgsmachtdelen aselect ingepland; de $\mathrm{KL}$ is slechts één van die krijgsmachtdelen. Gelet op de willekeurige wijze waarop kandidaten voor de aanstellingskeuring worden ingedeeld is er geen aanleiding om aan te nemen dat deze 227 kandidaten anders zijn samengesteld dan de overige bij de gerandomiseerde gecontroleerde studie betrokken kandidaten.

In de theorie is het bepalen dat er om de week op de ene dan wel op de andere wijze moet worden gekeurd niet het optimale design voor dit onderzoek. In de praktijk valt het gekozen design te verdedigen. Zo zou het dagelijks aanbieden van aselect in de twee keuringssystemen ingedeelde kandidaten aan elke keurend arts tot diverse problemen لeiden: het gevaar verstrikt te raken in verschillende diagnostische classificatieschema's [5], expectation bias [5], de hoge moeilijkheidsgraad van controle door derden op de correcte uitvoering en motivatieproblemen bij de keurend arts. Bij het IKS worden jaarlijks duizenden keuringen voor de vier krijgsmachtdelen (Koninklijke Marine, - Landmacht, Luchtmacht en - Marechaussee) verricht. Om dit instituut tijdelijk te laten werken met twee keuringssystemen (onder meer met 10 keurend artsen en drie uitslaggevend artsen), bleek deze oplossing in de praktijk de optimaal haalbare werkwijze. De betrokken artsen waren dezelfde die in 1998 de oorspronkelijke 
uitslag hadden gegeven; allen hadden dezelfde kennis van zaken van het nieuwe zowel als het oude keuringssysteem. Op grond hiervan lijkt selectiebias afdoende te zijn bestreden.

Het beoordelen wan schiffelijke dossiers om de mate van overeenstemming tussen artsen te beoordelen is een hiervoor regelmatig gebruikte methode. Hierin schuilt wel een beperking: men keurt immers niet fysiek en mist wellicht (non-verbale en verbale communicatieve) signalen. Het voordeel van deze methode is dat de betrokken artsen per definitie uitgaan van dezelfde gegevens. Bovendien vindt het uitslag geven van de gebruikelijke aanstellingskeuring door de uitslaggevend arts ook plaats op grond van het door de keurend arts opgestelde dossier, al dan niet toegelicht door diezelfde keurend arts. In die zin wijkt de gehanteerde procedure voor de uitslaggevend artsen niet veel af van de praktijksituatie.

Door het gebruik van dossiers in plaats van onderzoekspersonen worden het Hawthorne-effect [5], het placebo-effect [5], en het Pygmalion-effect [5] juist vermeden. Omdat bij de herbeoordeling de artsen inmiddels al meer dan een jaar met het nieuwe systeem hadden gewerkt, kan er ook geen sprake meer zijn van een eventueel novelty-effect [5]. Op grond van het bovenstaande wordt angenomen dat informatiebias afdoende is bestreden.

Er is sprake van een grote mate van overeenstemming, zowel wanneer de oude uitslagen met de nieuwe worden vergeleken, als de nieuw uitslagen onderling worden vergeleken. Tussen de oorspronkelijke uitspraak en de nieuwe is meer dan een jaar verstreken. Volgens Bouter en Van Dongen [5] kan een te lange tussentijd voor werkelijke veranderingen zorgen. Dit zou een verklaring kunnen zijn voor de overgang van het oordeel "goed" naar "voortreffelijk". Er zou sprake van een leereffect kurnen zijn, tenslotte hebben de betrokken artsen nu al meer dan een jaar in de praktijk met het nieuwe systeem gewerkt.

Gelet op de willekeurige volgorde warin de medische anstellingskeuring door het IKS in de tijd wordt gepland, berust het gesignaleerde verschil tussen beide keuringssystemen inzake de fysieke selectie op toeval.

De samenstelling van de gebruikte dossiers was representatief voor de gebruikelijke samenstelling van dergelijke dossiers. De verhoudingen tussen de geschikt verklaarden en ongeschikt verkaarden weerspiegelen het jaarlijks gemiddelde bij het IKS voor KL-kandidaten.

Het begrip "fysieke belastoaarheid" als medische bijzonderheid leidt wellicht tot vraagtekens. Enerzijds wordt die belastbaarheid door middel van instrumentarium gemeten zoals men ook de visus of het gehoor meet. Anderzijds kan 
men zich afvragen of en in hoeverre iemand die louter enige statische of dynamische kracht op een door de KL woorgestane schaal tekort komt, een medische bijzonderheid heeft. Daar waar bijvoorbeeld perceptief verlies bij het gehoor niet meer te herstellen valt, kan men zich vervolgens afvragen of dat met onvoldoende conditie soms wel het geval kan zijn. Dat kracht en conditie voor een functie als KL-militair belangrijk zijn valt niet te ontkennen, mat behalve onvoldoende conditie of kracht mankeren deze personen medisch niets. Aangezien juist conditieproblemen relatief tot het hoogste percentage afkeuringen leidt, lijkt nader onderzoek hiernaar gewenst.

De artsen zijn het bijna altijd met elkaar eens inzake de geschiktheid. Deze eensgezindheid heeft te maken met het feit dat bij de meerderheid van deze beoordelingen ook geen medische bijzonderheden worden gevonden: niets aan de hand betekent geschikt.

Het hierboven vermelde "leereffect" kent overigens een prijs. Zijn er oorspronkelijk 46 afgekeurden in 1998, (tabel 18), anno 2000 worden dat er in totaal tussen de 55 en 62 (Tabel 20). Dat is letterlijk het effect van de gedaalde discongruentie aan de afkeuringzijde $(O O)$, waardoor het total aan afkeuringen toeneemt.

Beoordeling van de reproduceerbaarheid van het nieuwe systeem bij de anstellingskeuring diende, zoals in de inleiding vermeld, plaats te vinden. Maar heeft het, bij het ontbreken van een "gouden standaard", zin om de gevonden uitslagen voor beide keuringssystemen met elkaar te vergelijken? Een lagere reproduceerbaarheid van het nieuwe systeem zou kunnen betekenen dat het ten aanzien van die kwaliteitseis relatief als minder goed dan het vorige systeem kan worden gekwalificeerd. Daardoor zou verder onderzoek als minder relevant zou kunnen worden beschouwd.

De reproduceerbaarheid van het nieuwe systeem blijkt evenzeer te voldoen aan de volgens Bouter en Van Dongen [5] gebruikelijke mate van reproduceerbaarheid volgens kappa als het oude systeem. Ook bij de overige gebruikte maten voor reproduceerbaarheid valt geen verschil te ontdekken.

De voor dit onderzoek gebruikte casus zijn afkomstig uit twee studiegroepen die (zie hoofdstuk 5) in weinig van elkaar blijken te verschillen. Op grond hiervan kan worden angenomen dat beide keuringssystemen inzake reproduceerbaarheid bij de aanstellingskeuring niet voor elkaar onderdoen.

Samengevat kan worden vastgesteld dat in de mate van overeenstemming tussen beide keuringssystemen geen statistisch significant verschil bestaat. In beide gevallen is sprake van een voortreffelijke overeenstemming. 


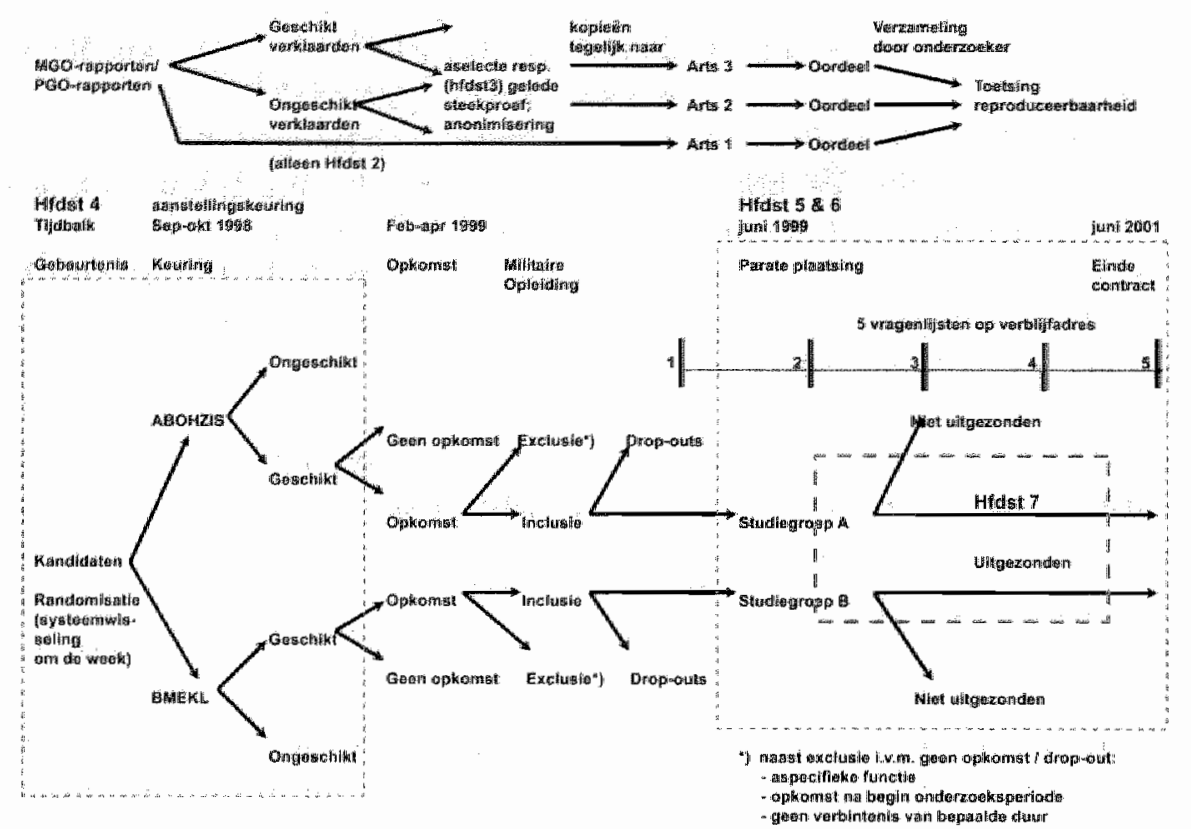

Figuor 15: Het overzicht van de onderzoeken uit dit proefschrift en de daarbij behorende hoofdstukken. In de hoofdstukken 2 en 3 wordt de reproduceerbartheid van het periodiek geneeskundig onderzoek, respectievelijk de pensioeinkeuring onderzocht, analoog an Figum 5 . Hoofdstuk 4 bevat soortgelijk onderzock voor wat betreft de anstellingskeuringen wan dezelfde gerandomiseerde, gecontroleerde studie, van wie de twee studiegroepen in de hoofdstukken 5 en 6 geclurende hun platsing op functie worden gevolgch om de worspellencle warde tussen beide keuringssystemen te kumnen vergelijken.

Daathoor lijkt bij luet gebruik van de BMEKL het uitsluiten wan gevaar voor de eigen veiligheid en gezondheid of die van anderen thans goed gewarborgd bij een aanstelling als militair bij de KL, als lonter wordt gekeken nar de mate van overeenstenming als kwaliteitsmaatstaf.

In hoodstuk 2 is de mate van overeenstemming van het ABOHZIS-keuringssysteem in geval van het Periodiek Geneeskundig Onderzoek (PGO) ten tijde van een grote reorganisatie in 1994 - 1996. De uitkomsten (kappas) van dat onderzoek sloten ann bij de bevindingen die De Kort in zijn onderzoek had gevonden. Dit hoofdstuk is omschreven als een systematische waarneming, die leidde tot de interesse in verder onderzoek. In de daarop volgende hoofdstukken is andacht besteed aan één gedeelte van de vraagstelling (figuur 15): de mate van overeenstemming als kwaliteitsmat.

In loofdstuk 3 is de inter-waanemers variatie bij de pensioenkeuring onderzocht voor het nieuwe keuringssysteem. De mate van overeenstemming bleek 


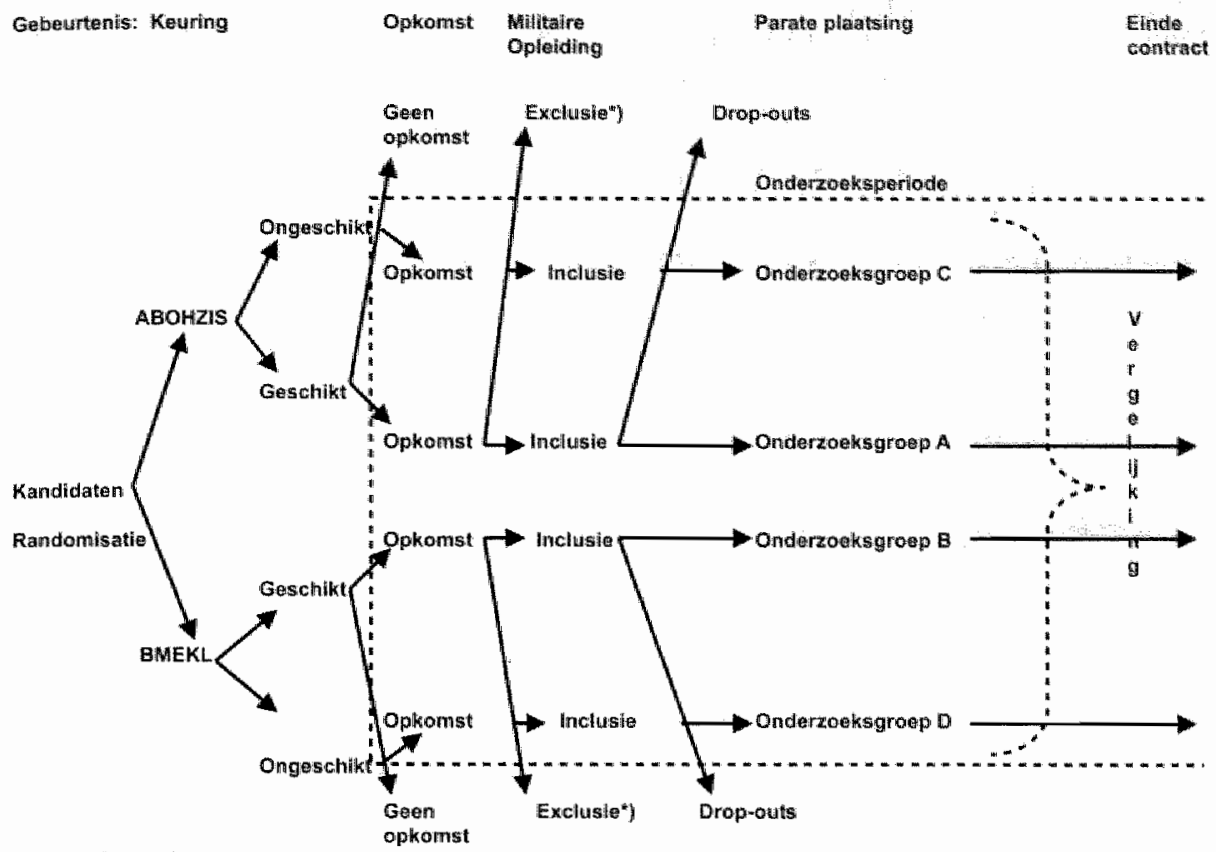

7 exclusiecriteria

Figuur 16: De ideale onderzoeksopzet woor de bepaling van de voorspellende warde.

Alle kandidaten, geschikt zowel als ongeschikt verklaard, worden na opkonst tot het einde van de arbeidsovereenkomst gewolgd.

hierbij, met name voor wat het definitieve eindoordeel betreft, kunnen worden omschreven als goed in de betekenis van de kappa.

In hoofdstuk 4 is aandacht besteed aan de mate van overeenstemming van beide keuringssystemen bij de aanstellingskeuring. Hieruit kwam nar voren dat deze mate van overeenstemming voor beide keuringssystemen als voortreffelyjk kan worden beschouwd. Daarmee wordt het onderwerp overeenstenuming voor wat dit proefschrift betreft afgesloten.

Een goede mate van overeenstemming is een noodzakelijke, maar op zichzelf staand onvoldoende voorwaarde voor de kwaliteit van een test. De meetuitkomsten moeten ook valide zijn. Om die validiteit te bepalen is ander onderzoek nodig. De resultaten van het nieuwe keuringssysteem konden niet aan een gouden standaard worden getoetst. Wel was het mogelijk on een simultane vergelijking te maken met een andere test met een onbekende validiteit: het oude ABOHZIS-keuringssysteem.

In de ideale onderzoeksopzet worden groeperingen kandidaat-militairen volgens één of beide systemen gekeurd en vervolgens aangenomen, opgeleid en. 
ingezet - onafhankelijk wan goed-of afkeuring (Guur 16). Het te werk stellen van ongeschikt verklarde militairen was echter geen halbare optie. Om praktische en ethische redenen geeft de KL-organisatie hiervoor geen toestemming. Nu zou er toe kunnen worden overgegaan om de afgewezen kandidaten op dezelfde wije te vervolgen gedurende dezelfde onderzoeksperiode als hun militaire, geschikt bevonden collega"s. Hierbij zouden zich drie problemen voordoen. Ten eerste waren de mogelijkheden on data voor bij de KL te werk gestelde militairen te verzamelen aanmerkelijk uitgebreider dan die voor de externe onderzoeksgroep. Hierdoor zou selectiebias optreden. Ten tweede zouden de arbeidsomstandigheden en functie-eisen van die externe onderzoeksgroep hoogstwaarschijnlijk grote individuele variatie vertonen. Door de te verwachten selectiebias zou hiervoor niet kunnen worden gecorrigeerd. Als derde zou het problematisch kunnen zijn om voldoende respons te verkrijgen.

Hierdoor resteerde alleen de mogelijkheid om onderzoek te verrichten nar verschillen tussen geschikt verklaarde militairen.

On dit te beoordelen is gedurende de periode juni 1999 - juni 2001 een gecontroleerde gerandomiseerde studie verricht. Bij het begin van de studie zijn keurlingen gerandomiseerd gekeurd door middel van éen van de twee keuringsystemen, $\mathrm{ABOHZIS}$ of BMEKL, hetgeen in de volgende hoofdstukken wordt weergegeven.

\section{Geraadpleegde literatuur}

1. Capaciteiten test:General Aptitude Tese Battery. GATB versie B 1002-b. Unites States Employement Service, 1958. Voor Nederland bewerkt door de Stichting GATB-resenrch. Swers 'Test Publishers, Lisse: 1994.

2. Fiter H wiñ der, Boominim-Sucrink JL: Handboek GATB B 1002-B. Utrecht, Swets Test Publishers, Lisse: 1994.

3. Lutelin F, Starren J, Dijk H van: Nederlandse Persoonlijkheids Vragenhijst (NPV). Swets Test Publishers, Lisse: 1974.

4. Lutejin F, Starten J, Dijk H van: Handleiding Nederlandse Persoonlijklaeids Vragenlijst (herziene witgave). Swets Thest Publishers, Lisse: 1985.

5. Bouter LM, Dongen MCJM van: Epidemiologisch onderzoek, opzet en interpretatie. Bohn, Staleu en van Loghum. Houten, 1995.

6. Kort WLAM, Post-Uiterween HW: Project a anstellingskeuringen dossieronderzoek bij de RBB. Deel II: panelonderzoek. Ministerie van Sociale Zaken en Werkgelegenheid, S 53-2, 1991.

7. Altman DG: Practical statistics for medical research. London: Chapnan and Hall, 1991.

8. Steinjans VW, Diletri E, Bömches B et al: Interobserver agreenent: Cohens Kappa coefficient does not necessarily teflect the percentage of patients with congruent classifications. Int J of Chin of Pharm And Ther. 1997; 35; 3:93-95. 


\section{5 | Een vergelijking tussen twee} systemen voor de aanstellingskeuring bij de Koninklijke Landmacht met behulp van een gerandomiseerde, gecontroleerde studie

In belangrijke mate overgenomen uit: Raad, J de, Redekop WK: A comparison between two systems for pre-employment medical assessment in the RNLA by a randomised-controlled study. Military Medicine $2004 ; 169(6): 437-443$. 


\subsection{Inleiding en vraagstelling van dit onderzoek}

In 1811 introduceerde Napoleon Bonaparte zowel de conscriptie als de medische keuring in het Nederlandse leger. Tot 1998 werd de medische aanstellingskeuring bij de Koninklijke Landmacht (KL) uitgevoerd met behulp van het daarvan afkomstige "Militair Keuringsreglement" (MKR) en de bijbehorende "Lijst van ziekten en gebreken".

Deze lijst van ziekten en gebreken werd van tijd tot tijd gemoderniseerd. Verder werd het aan de professionele autonomie van de keurend arts overgelaten om te beslissen of een keurling in voldoende ernstige mate aan een bepaalde ziekte of gebrek leed on te worden afgekeurd. Na de Tweede Wereldoorlog ontstond een groeiende behoefte tot verdere verfijning van het personele selectieproces in de KL. Daartoe adopteerde de Nederlandse overheid in 1946 het Canadese PULHEEMS-indelingssysteem, vertaald als ABOHZIS (Algemene toestand, Bovenste extremiteiten, Onderste extremiteiten, Horen, Zien, Intelligentie en Stabiliteit). Dit systeem werd gecombineerd met het MKR en de "Lijst van ziekten en gebreken". Door een verdere verbijzondering in 1967 werden praktisch alle toenmalig bekende ziekten en gebreken beschreven in termen van de ABOHZIS-classificatie. Na 1967 werd hierin geen verandering meer aangebracht.

Dit systeem vertoonde verschillende tekortkomingen [1]. Zo werden beperkingen opgelegd terwijl functie-eisen ontbraken. Voorts was aangetoond dat er een slechte overeenkomst bestond tussen de ABOHZIS-classificatie en de eisen die in de dagelijkse praktijk aan militairen worden gesteld [2]. Het systeem werd gehandhafd zolang de dienstplicht van kracht bleef, of juister tot deze in 1996 werd opgeschort. Hierna ontstond een snel groeiende behoefte aan een ander keuringssysteem.

In 1998 werden de Basismedische Eisen KL (BMEKL) als nieuw keuringssysteem geintroduceerd [3]. De te stellen eisen aan militairen waren in de vorm van 43 beoordelingspunten samengebracht, tezamen met keuringsprotocollen. Voor elk beoordelingspunt werd een te scoren grenswaarde gedefinieerd, de Basismedische Eis (hoofdstuk 1, tabel 1).

Dit systeem is door de overige krijgsmachtdelen overgenomen als nieuw keuringssysteem voor de aanstellingskeuring. Dit betekent dat een nieuw keuringssysteem bij de krijgsmacht is geïntroduceerd, gebaseerd op aan militairen te stellen eisen, dat bovendien niet strijdig is met de Wet op de Medische Keuringen uit 1998.

Het nieuwe keuringssysteem verschilt in belangrijke mate van het ABOHZIS-systeem. Het systeem houdt rekening met operationele inzetbaarheid. De eisen houden voorts rekening met zowel gedragswetenschappelijke elementen als taakspecifieke militaire vardigheden. De keurend arts dient te 
beoordelen of de rekruut op medische gronden in stat is om zonder beperkingen aan de gestelde eisen te voldoen. Is dit latste het geval dan wordt de rekruut goedgekeurd, ongeacht de aanwezigheid wan zlekte of gebrek: In het oude keuringssysteem bestonden geen functie eisen, evenmin als een relatie met operationele inzetbaarheid. Er bestond weinig medische interesse in gedragswetenschappelijke elementen. De goedkeuring van rekruten voor de militaire dienst was gebaseerd op het afwezig zijn van ziekten en gebreken, ongeacht of zij in staat waren om de vereiste taken wit te voeren, ondat die taken niet waren gedefinieerd.

Dit nieuwe keuringssysteem wordt thans gebruikt voor de aanname van militairen, die momenteel allen vrijwillig dienend zijn. De meeste rekruten krijgen een arbeidsovereenkomst voor een bepalde periode angeboden, in de regel bedraagt dit periode $21 / 2$ jaar ("Beroeps Bepaalde Tijd", "BBT"). Daarnanst is tevens sprake van beroepsmilitairen met een arbeidsovereenkomst voor onbepaalde tijd ("Beroeps Onbepaalde Tijd", "BOT"). Militairen BBT ondergaan gedurende de eerste 6 maanden na opkomst de algemene militaire opleiding, gevolgd door een functiegerichte opleiding. Manschappen worden opgeleid bij één van de vier Schoolbataljons, waarvan drie hetzelfde programma volgen. Het vierde Schoobataljon is bedoeld om manschappen op te leiden voor de Luchtmobiele Brigade en kent een zwaarder programma, dat 5 weken langer duurt. Officieren en onderofficieren worden op aparte opleidingsinstituten (Koninklijke Militaire Academie, KMA, respectievelijk Koninklijke Militaire School, KMS) opgeleid.

Sinds de omvorming van de op dienstplicht gebaseerde $\mathrm{KL}$ naar een beroepsleger ligt het percentage rekruten dat voortijdig de dienst verlaat in alle schoolbataljons tussen de 20 en 35 . Meestal verlaten deze rekruten de dienst in de eerste 12 weken. Velen vertrekken ondat zij uiteindelijk niet de gewenste functie krijgen of omdat het militaire leven niet an hun verwachtingen voldoet. Zelden is er een medische oorzaak voor hun vertrek.

Nadat het nieuwe keuringssysteem in werking was getreden, diende hat te worden geëvalueerd. Inmiddels zijn de reproducerbarheid van het keuringssysteem bij zowel de pensioenkeuring als de anstellingskeuring onderzocht. Beide onderzoeken leverden bevredigende resultaten op. Zo bleek bijvoorbeeld bij het vergelijken van de mate van overeenkomst tussen twee keurend artsen bij de pensioenkeuring de kappa van Cohen $0.74(0.48-0.98)$ te zijn [4]. De mate van overeenkomst van de annstellingskeuring tussen drie keurend artsen in de zin van $a+d / a+b+c+d(\%)$ bleek $97 \pm 0,6 \%$ te zijn $[5]$.

Het beoordelen wan de validiteit van het nieuwe keuringssysteem is ingewikkelder dan het beoordelen van de reproduceerbaarheid. Weliswaar voldoen 
zowel de onschrijving van de BMKEL als de keuringsprotocollen an "face validity", evenals aan "expert validity". Ook lijkt ten gevolge van die keuringsprotocollen, door de constante werkomstandigheden en door de supervisie van seniorbedrijfsartsen, de correcte uitvoering van de keuring gegarandeerd. Maar nimmer is de specificiteit of sensitiviteit van het BMEKL-keuringssysteem onderzocht, evenmin bestaat er een "gouden standaard".

Tengevalge van meerdere redenen, waronder ethische, is het niet mogelijk om ongeschikte kandidaten aan te nemen en onder dezelfde (militaire) arbeidsomstandigheden te volgen als de geschikt verklaarde soldaten. Voorts zou het erg moeilijk worden om een vergelijking te maken over een langere periode tussen de ongeschikt verklaarden, werkzaam in de civiele sector, en de geschikt verklaarden (selectie-bias, informatie bias, uiteenlopende arbeidsomstandigheden, evenals een gebrekkige respons, waardoor voor die arbeidsomstandigheden niet zou kunnen worden gecorrigeerd). Hetzelfde geldt ten aanzien van. diegenen die weliswaar geschikt zijn verkaard, maar niet in dienst zijn getreden, evenals voor diegenen die teeds tijdens de algemene militaire opleiding de dienst alweer verlaten.

Om deze redenen is ervoor gekozen beide keuringssystemen te vergelijken voor wat betreft het vermogen om geschikte rekruten op te leveren. Daarbij worden twee uitkomstvariabelen gehanteerd, te weten het aantal dagen inzetbaarlheid en de hoeveelheid medische consumptie. Hiervoor werd van juni 1999 tot en met juni 2001 een gerandomiseerde, gecontroleerde studie verricht (figuur 17). De vraagstelling voor dit onderzoek luidde: "Is er een verschil in prognostische waarde tussen beide keuringssystemen ten aanzien van de geschikt verklaarde militairen BBT op het gebied van de dagen inzetbaarheid en/of de genoten medische consumptie?"

\subsection{Materiaal en methoden}

\subsubsection{Populatie en procedure}

Twee studiegroepen werden samengesteld. Daarbij werden deelnemers uit groep éen gekeurd volgens het ABOHZIS-systeem ("ABOHZIS") en deelnemers uit groep twee volgens het BMEKL-systeem ("BMEKL"). Tussen 22 september en 16 oktober 1998 zijn 863 kandidaten gekeurd, waarbij randomisatie plaatsvond door iedere week van keuringssysteem te wisselen (figuur 17). Dit leidde tot de uiteindelijke samenstelling van twee onderzoeksgroepen van in totaal 352 personen, warvan 166 in de ABOHZIS-studiegroep en 186 in de BMEKL-studiegroep. 


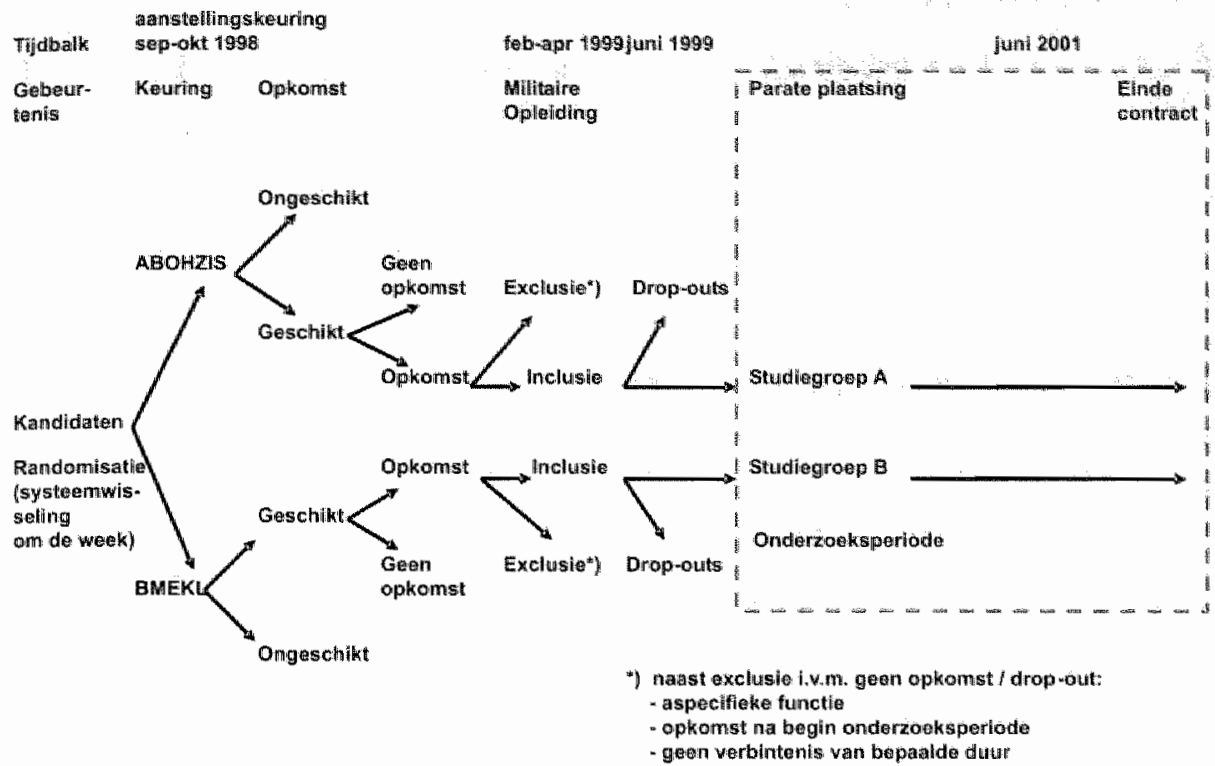

Figuur 17: De onderzoeksopzer van de gerandomiseerde gecontroleerde studie.

Na gerandonniseard te zijn gekeurd worden de geschike verklaarde kandidaten na opkonnst gedurende de periode van paratstelling (twee jaar) tot het einde van de arbeidsovereenkomst gevolgd.

\subsubsection{Informatie}

Voor het nalopen van de te onderzoeken variabelen werd van de volgende middelen gebruik gemaakt: dossiers van de aanstellingskeuring, exitinterviews afgenomen bij dienstverlaters, centraal beheerde platsingsgegevens, het decentraal ingevulde, mar centraal gecontroleerde en beheerde verzuimregistratiesysteem, gegevens afkomstig van de afkeuring, ingediende claims, de interne geneeskundige verrichtingenadministratie zoals opgemalakt door de militaire zorgwerleners en declaraties bij de ziektekostenverzekeraar.

\subsubsection{Exclusie van verder onderzoek}

De onderzoeksperiode liep van 1 juni 1999 tot 1 juni 2001. De redenen voor exclusie waren: ongeschikt verklaring, militairen BOT, geen opkomst respectievelijk vertrek reeds in de militaire opleiding, opkomst na 1 juni 1999 en atypische functies (bijvoorbeeld militaire muzikant). 


\subsubsection{Effectvariabelen}

Inzetbaarheid. Per kandidaat is over de onderzoeksperiode het aantal (kalender-)dagen inzetbaarhéd bepaald door aftrek van het aantal dagen ziekteverzuim of andere vormen van arbeidsverzuim, zoals beperkte operationele inzetbaartheid door blessures, vastgesteld door een arts. Hierbij bepaalde het klassieke ziekteverzuim 95\% van het totaal en kon de zuivere inzetbaarheid ( het aantal kalenderdagen dat een militair operationeel had kunnen worden ingezet) worden bepaald.

Medische consumptie. De KL bezit een eigen eerstelijns geneeskundig zorgsysteem (huisartsenzorg) en voorziet voor de belangrijkste klinisch specialismen ook in de tweede lijns gezondheidszorg. Die eerste lijns zorg geldt echter in eigen land slechts onder kantooruren. Tijdens operationele inzet en bij plaatsing in Duitsland wordt 24 uur per dag eerstelijns gezondheidszorg verstrekt. Buiten kantooruren kan een militair zich tot een civiele (eerste of tweedelijns) zorgverlener wenden; hiervoor is de militair verzekerd.

De verrichtingen van de eigen eerste lijn worden in een centrale database vergaard. Alle tweedelijns verrichtingen, alsmede extern geraadpleegde eerstelijns verrichtingen worden door de ziektekostenverzekeraar vergoed na declaratie. Om een volledig overzicht te verkrijgen over de total gemaakte medische kosten moeten zowel de ziektekostenverzekeraar als de database worden geraadpleegd.

De medische eerstelijns consumptie is berekend door alle eerste lijns consulten te rekenen naar het gemiddeld over de onderzoeksperiode geldende CTG-tarief $(€ 17,92)$. De overige gemalakte en gedeclareerde ziektekosten zijn bij de ziektekostenverzekeraar opgevraagd.

\subsubsection{Statistische methoden}

Om de verschillen tussen beide studiegroepen te toetsen is voor continue variabelen gebruik gemaakt van zowel de Mann-Whitney-U test als de Kruskal-Wallis $\mathrm{H}$ test, voor dichotome variabelen de Pearson Chikwadraattest. Voorts zijn multiple lineaire regressie analyses uitgevoerd.

\subsection{Resultaten}

In total werden in de ABOHZIS-groep 399 kandidaten gekeurd, waarvan 304 geschikt werden bevonden (tabel 21). Daarvan kwamen uiteindelijk 243 beroeps bepaalde tijd (BBT) op, waarvan op grond van de exclusiecriteria uiteindelijk 166 in de studiegroep belandden. Voor de BMEKL-groep lag dit als volgt: 464 kandidaten werden gekeurd, waarvan 341 geschikt werden verklaard; 
Tabel 21. Het werloop van de gekenurde nulitainen.

\begin{tabular}{|c|c|c|c|c|c|}
\hline \multirow[b]{2}{*}{ Gekend } & \multicolumn{2}{|c|}{ ABOHZIS groep } & \multicolumn{2}{|c|}{ BMEKX groep } & \multirow[t]{2}{*}{$p$} \\
\hline & 399 & $100 \%$ & 464 & $100 \%$ & \\
\hline Afgekeurd & -64 & $16 \%$ & -58 & $13 \%$ & 0,14 \\
\hline Uitvall door fysieke selectie & -31 & $8 \%$ & -65 & $1.4 \%$ & $<0,01$ \\
\hline Geschikt & 304 & $76 \%$ & 341 & $73 \%$ & \\
\hline Beroeps Onbepaalde Tija (BOT) & -8 & $2 \%$ & -17 & $4 \%$ & 0,12 \\
\hline Niet bij KL maar alders & -15 & $4 \%$ & -18 & $4 \%$ & 0,84 \\
\hline Nooit opgekomen & -36 & $9 \%$ & -33 & $7 \%$ & 0,38 \\
\hline Anders & -2 & $1 \%$ & -3 & $1 \%$ & 0.75 \\
\hline Beroeps Bepaalde Tijd (BBT) & 243 & $61 \%$ & 270 & $58 \%$ & 0,76 \\
\hline Te kort in dienst & -75 & $19 \%$ & -80 & $17 \%$ & 0,50 \\
\hline Te laat in dienst & -2 & $1 \%$ & -4 & $1 \%$ & \\
\hline Onderzocksgroep & 166 & $42 \%$ & 186 & $40 \%$ & $40 \%$ \\
\hline
\end{tabular}

"Anders" staat voor afwijkende militaire furcties, zoals geestelijk verzorger en militaire nuzikant.

hiervan kwamen 270 BBT-ers op, hetgeen resulteerde in een studiegroep van 186 op grond van de exclusiecriteria.

Uit tabel 21 blijkt dat alleen een statistisch significant verschil op grond van de fysieke selectie tussen de keuringssystemen bestond. De persoonskenmerken van diegenen die geschikt verklaard zijn maar nooit opkomen, verschillen niet per keuringssysteem. Aanvullend kan worden vermeld dat de periode die tussen het moment van de aanstellingskeuring en het moment van de daadwerkelijke opkomst lag, $136 \pm 34$ kalenderdagen bedroeg.

Van 100 van de 155 militairen die binnen 12 weken alweer afzwaaien kon het exit-interview worden achterhaald. Van hen geven 4 een medische reden op, 11 geven aan de fysieke belasting toch te $z$ waar te vinden. De overige 85 geven andere, niet-medische redenen op. Geen van de in totaal 155 vroege dienstver]aters dient een claim in op grond van het Kaderbesluit Militaire Pensioenen, hetgeen de suggestie wekt dat de kans op serieuze medische problemen onder de vroege dienstverlaters als gering mag worden beschouwd.

Uit de beginsituatie (tabel 22) blijkt dat geen van de onderzochte variabelen statistisch significant verschilt tussen beide studiegroepen. Buiten de in tabel 22 vermelde variabelen is voorts nog gekeken naar de fysieke selectie $(p=0,72)$, medische bijzonderheden $(p=0,54)$, de schoolopleiding $(p=0,20)$ en de 
Tabel 22. Te peroonkewmeten an het begin wan de onderzoksperode.

\begin{tabular}{|c|c|c|c|c|c|c|}
\hline \multicolumn{2}{|l|}{ Wantubetle } & \multicolumn{2}{|c|}{ ADOHLW } & \multicolumn{2}{|l|}{ BMERL } & \multirow[b]{2}{*}{$\mathrm{P}$} \\
\hline & & $N=168$ & $\%$ & $N=188$ & $\%$ & \\
\hline Letrijd & & $20,8 \pm 2,5$ & & $20,8 \pm 27$ & & 0,95 \\
\hline Cugbadrt & Man & 146 & 88,0 & 169 & 91,0 & 0,37 \\
\hline Denografisch: & Stedelijk & 46 & 27,7 & 64 & 34,4 & \\
\hline$>7<50.060$ inwoners & Platteland & 103 & 62,0 & 104 & 55,9 & 0,40 \\
\hline \multirow[t]{2}{*}{ Gransamenstolling } & Compleet & 115 & 69,3 & 133 & 71.5 & \\
\hline & Incomplaet & 34 & 20,5 & 37 & 19.9 & 0.85 \\
\hline Roketr (sigaretcon) & Jat & 98 & 59,0 & 109 & 58,6 & 0,92 \\
\hline \multirow[t]{4}{*}{ Butgerlijke Statat } & Ongehuwd & 156 & 94,0 & 180 & 96,8 & \\
\hline & Samenwonend & 2 & 1,2 & 3 & 1,6 & \\
\hline & Gehuwd & 6 & 3,6 & 3 & 1,6 & \\
\hline & Gescheiden & 1 & 0.6 & 0 & & $0_{1} 44$ \\
\hline Recidivise (eerder ith dienst) & Ja & 8 & 4,8 & 14 & 7,4 & 0,30 \\
\hline
\end{tabular}

Toelichting Onder "Incompleet" bij gezinssanenstelling wordt werstan ovders gescheden of én dst: ouders overleden.

verhouding tussen geschikt- en ongeschiktverklaring van de 10 verschillende keurend artsen $(p=0,27)$.

In tabel 23 staan de uitkomstvariabelen. Er is een statistisch significant verschil tussen beide studiegroepen inzake plaatsing naar gevechts- of gevechtsondersteunende functies ( $p=0,02$; de BMEKL-groep telt meer gevechtsfuncties, de ABOHZIS-groep meer gevechtsondersteunende functies), dagen inzetbaarheid $(p=0,02)$ en medische consumptie $(p=0,05)$. Het aantal dagen inzetbaarheid wordt voor $95 \%$ bepaald door ziekteverzuim en voor $5 \%$ door andere vormen van arbeidsverzuim, hoofdzakelijk door medische beperkingen ten aanzien van de operationele inzetbaarheid (blessures e.d). De inzetbaarheid valt voor zowel gevechts-als gevechtsondersteunende functies in de BMKEL-groep hoger uit dan de ABOHZIS-groep.

De onderzoeksgroepen zijn ook per militaire opleidingsplaats naar de dagen inzetbaarheid en medische consumptie tussen de keuringssystemen vergeleken. Hierbij bleek dat de onderlinge verschillen alleen statistisch significant waren ten aanzien van het aantal dagen inzetbaarheid bij de opleiding van het Schoolbataljon Luchtmobiel $(\mathrm{p}=0,01)$, gevolgd door het resultaat voor wat betreft Schoolbataljon Zuid $(p=0,06)$. Beoordeling van verschillen tussen de studiegroepen op grond van de plaats waar de Algemene Militaire Opleiding is gevolgd levert een $\mathrm{p}$-waarde van 0,06 op. 
Tabel 23. De uitkomstwablabelen gedurende de ondenzoekperiode.

\begin{tabular}{|c|c|c|c|c|c|c|}
\hline \multirow[b]{2}{*}{ Variabele } & & \multicolumn{2}{|l|}{$\mathrm{ABOHZ \textrm {L }}$} & \multicolumn{2}{|l|}{ BMEKL } & \multirow[b]{2}{*}{$p$} \\
\hline & & $N=166$ & 8 & $M=180$ & $\%$ & \\
\hline Militaire Opleiding & Noord & 25 & 15,1 & 36 & 19,4 & \\
\hline (Opl manschappen & Centraal & 75 & 45,2 & 64 & 34,4 & \\
\hline 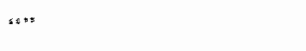 & Zuid & 28 & 16,9 & 23 & 12,4 & \\
\hline :us & LMB & 23 & 13,9 & 39 & 21,0 & \\
\hline$\approx *$ & Ander: & 8 & 4,8 & 11 & 5,9 & \\
\hline (Opl onderofficier) & KMS & 7 & 4,2 & 9 & 4.8 & \\
\hline (Opl officien) & KMA & 0 & 0,0 & 4 & 2,2 & 0,06 \\
\hline \multirow[t]{7}{*}{ Platsing } & $11 \mathrm{LMB}$ & 16 & 9,6 & 31 & 16,7 & \\
\hline & 13 Mechbrig & 32 & 19,3 & 32 & 17,2 & \\
\hline & 41 Mechbrig & 27 & 16,3 & 30 & 16,1 & \\
\hline & 43 Mechbrig & 17 & 10,2 & 24 & 12,9 & \\
\hline & Divisietroepen & 57 & 33,1 & 54 & 26,3 & \\
\hline & Overig & 13 & 7,8 & 19 & 10,3 & \\
\hline & IBDKL & 6 & 3.6 & 1 & 0.5 & 0,36 \\
\hline Uitzending & Wel uitgezonden & 54 & 47,6 & 62 & 45,2 & 0,59 \\
\hline Indeling gevechisfunctie & Gewechtsfunctie & 71 & 41,5 & 105 & 57.5 & \\
\hline Ondersteunende functie & Ondersteunend & 95 & 58,5 & 81 & 42,5 & 0,02 \\
\hline Dagern inzet, max 731 & & $6 \| 2 \pm 170$ & & $648 \pm 134$ & & $<0,01$ \\
\hline Madische consumptie & $\in / 73 \| \mathrm{dgn}$ & $746 \pm 2170$ & & $396 \pm 958$ & & 0,05 \\
\hline
\end{tabular}

Tochichtingr. LMB staat woor Luchtmobiele Brigade, Mechbrig woor Gemechaniseende brigade, ITSDKL = platsing i.v.m. langdurig verminderdk inzetbaancid als militair. Opl stat voor opleiding. De p-waarden van dagen inzet en medische constumptie zijn berekend met behulp wan de Mann-Whincy-U test, woor de overige p-warden is de chi-k wadrattest gebruikt.

Soms volgt na platsing op het definitieve onderdeel nogmaals een overplatsing. Uiteindelijk blijkt dat in total 19 militairen naar de speciale eenheid voor Jangdurig verminderd inzetbare militairen (Individuele Begeleidingsdienst KL, IBDKL) zijn overgeplaatst: 13 uit de ABOHZIS-groep en 6 uit de BMEKL-groep. Het verschil wordt echter niet statistisch significant $(p=0,17)$. Het aantal uitgezonden militairen is evenmin verschillend tussen beide onderzoeksgroepen.

Na het vinden van deze verschillen in inzetbaarheid en medische consumptie tussen de studiegroepen is onderzocht of een associatie kon worden gevonden tussen deze uitkomsten en andere gegevens over deze rekruten. Daarvoor 
Tabel 24. Multiple hincare regressie nar keuringssysteem en militante opleiding(-sphats) met achtereenvolgens dagen inzetbaaneid en medische consunptie als afhankelijke variabelen.

\begin{tabular}{|c|c|c|c|c|c|c|c|c|}
\hline \multirow[t]{2}{*}{$\begin{array}{l}\text { Onaflianketijhe } \\
\text { Wariaben }\end{array}$} & \multicolumn{4}{|c|}{$\begin{array}{l}\text { Afhankelijke variabele: } \\
\text { dagen inzetbaarheid }\end{array}$} & \multicolumn{4}{|c|}{$\begin{array}{l}\text { Afhankelijke variabele: } \\
\text { Medische consurnptie }\end{array}$} \\
\hline & $\begin{array}{l}\text { Beta } \\
\text { coefficientit }\end{array}$ & $\begin{array}{l}\text { Standaatd } \\
\text { Fout }\end{array}$ & P. & $\mathrm{R}^{2}$ & $\begin{array}{l}\text { Bètal } \\
\text { coèfficiènt }\end{array}$ & $\begin{array}{l}\text { Standaard } \\
\text { fout }\end{array}$ & P. & $\mathrm{R}^{2}$ \\
\hline $\begin{array}{l}\text { Keuringsystedm } \\
\text { (BMEKL ABOHZIS) }\end{array}$ & 43 & 16 & 0,01 & & -376 & 171 & 0,03 & \\
\hline \multicolumn{9}{|l|}{ Type opleiding wersus } \\
\hline \multicolumn{9}{|l|}{ Overige typen opleiding } \\
\hline Opleiding officier & -86 & 46 & 0,06 & & -415 & 477 & 0,39 & \\
\hline Opleiding onderofficier & 80 & 78 & 0,30 & & -251 & 812 & 0,76 & \\
\hline Schoolbataljon LMB & 71 & 42 & 0,09 & & -316 & 437 & 0,47 & \\
\hline Schoolbataljon Zuid & -39 & 27 & 0,14 & & 404 & 277 & 0,115 & \\
\hline Schoolbataljon Centraal & 20 & 28 & 0.47 & & 410 & 293 & 0,16 & \\
\hline \multirow[t]{2}{*}{ Schoolbataljon Noord } & 15 & 22 & 0.52 & & -103 & 234. & 0,66 & \\
\hline & \multicolumn{7}{|c|}{0,06} & 0,04 \\
\hline
\end{tabular}

Toelichring: Schoolbataljons leiden manschappen op; kaderleden worden opgeleid op aparte instituten. $\mathrm{R}^{2}$ stat voor vertilarde variantie.

bestonden twee redenen. In de eerste plaats om de grootte van het effect van het keuringssysteem beter in te kunnen schatten, in de tweede plaats om het mechanisme te ontdekken waarom het BMEKL-systeem tot hogere uitkomsten had geleid. Hiervoor zijn per afhankelijke variabele telkens twee lineaire regressiemodellen gebruikt.

Bij multiple lineaire regressie analyse met inzetbaarheid als afhankelijke variabele en het keuringssysteem $(p=0,02)$, de militaire opleidingsplaats $(p=0,00)$ en gevechts- of gevechtsondersteunende functie $(p=0,88)$ als onafhankelijke variabelen bleek een associatie tussen de eerste twee onafhankelijke variabelen en inzetbarheid. Bij een tweede regressie model met inzetbaarheid als afhankelijke variabele tegenover het keuringssysteem en alle militaire opleidingsplaatsen afzonderlijk als onafhankelijke variabelen (tabel 24) bleek alleen een associatie tussen inzetbaarheid en het type keuringsysteem aanwezig $(p=0,01)$. De p-warde van de opleiding tot officier is weliswaar ook slechts 0,06 maar slechts 4 personen uit beide studiegroepen werden opgeleid tot officier. Bij mulciple lineaire regressie analyse met medische consumptie als afhankelijke variabele en het keuringssysteem, de militaire opleidingsplaats en gevechts- of 
gevechtsondersteunende functie als onafthankelijke variabelen bleek alleen het keuringsysteem alls onathankelijke variabele statistisch significant van iniloed te zijn $(p=0,01)$. Bij een tweede regressie model met medische consumptie als afhankelijke variabele tegenover het keuringssysteem en alle militaire opleidingsplaatsen afzonderlijk als onafhankelijke variabelen (tabel 24 , tweede deel) wordt dit beeld bevestigd.

\subsection{Beschouwing}

In deze studie bleken militairen, gekeurd volgens het nieuwe keuringssysteem (BMEKL) en gevolgd gedurende een periode van twee jaar na de opleiding, statistisch significant meer dagen (648 versus 612) inzetbaar te zijn en minder medisch te consumeren ( $€ 396$ versus $€ 746$ ) dan militairen die terzelfder tijd volgens het oude keuringsysteem (ABOHZIS) zijn gekeurd.

Hierboven is reeds vermeld dat juist tussen manschappen uit beide keuringsystemen een statistisch significant verschil in inzetbaarheid bestond indien zij afkomstig waren van de zwaarste opleiding. Het voorkomen van meer gevechtsfuncties in de BMKEL-studiegroep heeft wellicht te maken met verschillen in trainingsresultaten tussen beide studiegroepen.

Er was echter geen verschil in de absolute aantallen geschikt verklaarde kandidaten, evenmin alls in het percentage vroege drop-outs om niet-medische redenen. Het nieuwe systeem is niet strenger, malar brengt ook geen verlaging van het aantal vroege drop-outs. De verklaring voor deze latste bevinding is dat de oorzaken voor dienstverlating (exit-interviews, geen claims) van niet-medische aard zijn en door een keuringssysteem hoe dan ook niet worden beinvloed. Het bovenstaande roept drie vragen op. Beïnvloedt het keuringssysteem het type militaire opleiding dat voor en door de kandidaat wordt gekozen? En als dat zo is, beinvloedt deze militaire opleiding vervolgens zelf de inzetbaarheid? En als dat niet zo is, welke factor kan anders de gevonden verschillen verklaren? Wat de eerste vraag betreft: naar welke opleiding de kandidaat gaat is in de praktijk afhankelijk van de eigen wensen van de kandidaat en van de momentane vullingbehoefte bij de KL. Dit maakt het onaannemelijk dat de keuze voor het type opleiding wordt beinvloed door het keuringssysteem.

Of de training zelf iemands inzetbaarheid kan beïnvloeden blijft onduidelijk. Wel is sprake van een statistisch significant verschil in inzetbaarheid tussen beide onderzoeksgroepen voor zover ze afkomstig zijn van de zwaarste (luchtmobiele) opleiding. Als nu onder die kandidaten de verschillen het kleinst zouden zijn geweest, zou een relatie tussen het type militaire opleiding en de inzetbarheid aannemelijk zijn: de meest gemotiveerde en best inzetbare militairen zouden in dat geval bewust voor de zwaarste functies opteren. Nu echter onder die 
zwatrste functies het verschil in inzetbaarheid het grootst is tussen belide keuringssystemen, lijkt het er eerder op dat de verschillen tussen beide keuringssystemen juist bij die zwaarste functies tot uiting komen.

Wat de laatste vraag betreft kan het antwoord niet uit dit onderzoek worden verkregen. Na het vaststellen van het verschil in zowel inzetbaarheid als medische consumptie tussen beide keuringssystemen is zonder resultat onderzocht of andere factoren konden worden gevonden die met de twee uitkomstmaten waren geassocieerd. Er is derhalve een associatie tussen het keuringssysteem en de twee uitkomstmaten, waarvan het mechanisme op grond van de gepleegde analyses niet kon worden achterhaald. Voorlopig wordt dit mechanisme verklaard op basis van het verschil tussen beide keuringssystemen.

Het verschil in uitval op grond van fysieke selectie heeft te maken met het feit dat de BMEKL-groep op basis van toeval meer vrouwelijke kandidaten bevatte, woor wie de fysieke selectie relatief zwaarder is. In de uiteindelijke studiegroepen is geen verschil meer naar geslacht.

De voornaamste reden om niet op te komen na geschikt verklaring lijkt de vertraging van vier maanden die tussen keuring en opkomst ligt. De vroegtijdige uitval van relatief veel geschikte kandidaten vindt niet op medische gronden plaats. De uitslagen van de in deze studie gebruikte exit-interviews sluiten aan bij uitslagen van alle exit-interviews sinds deze in 1996 worden afgenomen, in die zin dat daarin eveneens zelden medische oorzaken voor de vroege "drop-out" naar voren komen.

In deze studie is ervoor gekozen om beide keuringssystemen te vergelijken voor wat betreft hun vermogen om inzetbare militairen op te leveren, tevens kijkend naar de medische consumptie. Weliswaar had follow-up van de ongeschikten mogelijk nog meer informatie kunnen verschaffen, maar het onthreken, biervan. doet geen afbreuk aan de resultaten van deze studie.

Fouten in de interne validiteit zijn voorkomen door randomisatie en het gebruik van data van goede kwaliteit centraal beheerd en gecontroleerd binnen de KL). Ten gevolge van die toevallige samenstelling en omdat de groepen goed vergelijkbaar zijn met de samenstelling van de gehele populatie aan KL-rekruten, kan worden gesteld dat in de externe validiteit geen fouten zijn opgetreden. Ten gevolge van de juiste groepsgrootte, de gebruikte statistische methoden en betrouwbarheidsintervallen was het mogelijk om fouten in de precisie te vermijden.

Tussen het keuringssysteem en de twee uitkomstmaten is een associatie vastgesteld, waarvan het mechanisme niet kon worden achterhaald. Voorlopig wordt dit mechanisme verklaard op basis van het verschil tussen beide keuringssystemen. Nader onderzoek wordt aanbevolen om dit mechanisme te achterhalen. In dit onderzoek is gebruik gemaakt van gegevens over de onderzoekspopulatie. 
Volgens Broersen [6] beinvloedt het beleven van de gezondheid, respectievelijk de gezondheidsrisico's het effect dat deze gezondheidsrisico's op de werknemer uitoefenen. Navraag bij de onderzoeksgroep naar hun persoonlijk beleven had relevante informatie kunnen opleveren teneinde het mechanisme achter de relatie tussen het keuringssysteem en de uitkomstvariabelen te achterhalen. Een vragenlijst zou derhalve wellicht kunnen helpen om verder na te gaan waar de in dit onderzoek gevonden verschillen op berusten.

\section{Geraadpleegde literatuur}

1. Raad J de, Reulings PG], Schouten HIA: De beperkingen van medische beperkingen. Ned Mil Geneesk $T ; 1996 ; 49: 106-111$.

2. Kessel JGFM van: Consequenties van onjuist keuren. Ned Mil Geneesk T; 1984: 37 : $176-228$

3. Raad J de, Peters JHM, Groot RP de et al: Modernisering van het keuringssysteem bij de: Koninklijke Landmacht. TBV 2000; 8: 110-115.

4. Raad J de, Peters JHM. Nijhuis FIN: De kwaliteit van een keuringssysteem. TBV 2000; 8:105-109.

5. Raad J de, Slootman EJH, Groot RP de: Kwaliteitsverbetering bij de Koninklijke Landmacht. Onderzoek naar de kwallteit van het beoordelen van anastellingskeuringen voor de Koninklijke Landmacht. TBV 2002; 10:266-272.

6. Broersen JPJ, Weel ANH, Dijk FJH van:Periodiek Bedrijfsgeneeskundig Onderzoek; middel en maatstaf. Amsterdam, 1989. 


\section{6 | Analyse van het verschil in prognostische waarde tussen beide keuringssystemen}

In belangrijke mate overgenomen uit: Raad, J de, Redekop WK: Analysis of health factors as predictors for the functioning of military personnel. Military Medicine 2005: 170(1): 14-20. 


\subsection{Inleiding en vraagstelling voor dit onderzoek.}

In november 1998 is bij de Koninklijke Landmacht (KL) een nieuw keuringssysteem in gebruik genomen, de Basismedische Eisen KL[1] (BMEKL), ter vervanging van het vorige systeem (ABOHZIS). Het nieuwe systeem is gebaseerd op het model belasting-belastbaarheid en gaat uit van functie-eisen, het oude was diagnosegericht en liet de arts toetsen op de aanwezigheid van ziekten en gebreken.

Om te onderzoeken of tussen beide keuringssystemen verschillen bestaan qua vermogen om geschikte rekruten te onderscheiden, is in de periode juni $1999-$ juni 2001 een gerandomiseerde gecontroleerde studie verricht. Daarbij werd een groep van 352 militairen BBT gedurende een periode van twee jaar gevolgd, nadat zij gerandomiseerd via én van beide keuringssystemen waren goedgekeurd en vervolgens opgeleid. Als maatstaven voor het vermogen om geschikte rekruten te onderscheiden werden de variabelen medische consumptie en het aantal dagen inzetbaarheid gehanteerd [2].

Uit deze studie bleek dat militairen die waren gekeurd volgens het nieuwe keuringssysteem statistisch significant meer dagen (648 versus 612) inzetbaar waren en minder medisch consumeerden ( $€ 396$ versus $€ 746$ ) dan militairen die terzelfder tijd volgens het oude keuringsysteem waren gekeurd. Hierna is onderzocht of andere factoren konden worden gevonden die met de twee uitkomstmaten waren geassocieerd. Weliswaar werd daarbij een associatie tussen het keuringssysteem en de twee uitkomstmaten vastgesteld, maar op grond van de gepleegde analyses kon het mechanisme daarvan niet worden achterhaald. Voorlopig is dit mechanisme verklaard op basis van het verschil tussen beide keuringssystemen.

Eerder onderzoek naar het effect van aanstellingskeuringen door De Kort [2] had angetoond dat anstellingskeuringen slechts weinig effect op werknemers uitoefenden. Hij onderzocht de relatie tussen het uitvoeren van aanstellingskeuringen en het optreden van arbeidsongeschiktheid door het optreden van beroepsziekten. De Kort voegt aan zijn hoofdconclusie toe dat het gebruik van een aanstellingskeuring aanvaldbaar kan zijn als het te vermijden risico groot wordt geacht. De risico's voor militairen bij de KL kunnen inderdaad groot zijn, met name gedurende operationele inzet. Het nieuwe BMEKL-systeem is afgeleid van de dagelijkse te verrichten militaire werkzaamheden - inclusief dit operationeel optreden - en vanuit die optiek bezien zou dit systeem in theorie dan ook tot betere resultaten moeten leiden dan het oude ABOHZIS-systeem, in de zin van langduriger imzetbare militairen en/of lagere medische consumptie. Dit laat de vraag open of de in het vorige onderzoek gevonden verschillen tussen beide studiegroepen werkelijk moet worden toegeschreven 
aan een verschil in het keuringssysteem of dat (ook nog) andere factoren van invloed een rol spelen.

Er zijn veel factoren mogelijk die de inzetbaarheid van werknemers beïnvloeden [3], zonder dat die invloed direct tot uitval wegens arbeidsongeschiktheid door beroepsziekte leidt. Die invloed kan bijvoorbeeld beperkt blijven tot een algemeen gevoel van onbehagen, frequenter artsenbezoek en kortdurend ziekteverzuim, waardoor zowel inzetbaarheid als medische consumptie worden beinvloed zonder dat er sprake is van een beroepsziekte die tot arbeidsongeschiktheid leidt. Daaraan kan worden toegevoegd dat uit de studie van Broersen, Weel en Van Dijk blijkt dat de eigen beleving van gezondheidsrisico's invloed uitoefent op het effect dat gezondheidsrisico's werkelijk uitoefenen op de betreffende werknemer [4]. De persoonlijke beleving kan aldus mede de onderzoeksuitkomsten (ziekmelding, uitval) beinvloeden. Het gebruik van bijvoorbeeld een periodieke vragenlijst zou op grond hiervan een toegevoegde waarde kunnen hebben bij verder onderzoek, met name om na te gaan wellk mechanisme achter de associatie tussen het keuringssysteem en de uitkomstvariabelen schuilgaat.

Gedurende de onderzoeksperiode zoals vermeld in het vorige onderzoek werd halfjaarlijks aan de bij het onderzoek betrokken kandidaten een vragenlijst aangeboden, met als doel om inzicht te krijgen in het beleven van de gezondheid, respectievelijk de gezondheidsrisico's door die onderzoekspersonen zelf. De vraagstelling voor dit onderzoek luidde: "Indien een verschil in prognostische waarde tussen beide keuringssystemen wordt gevonden, kan het mechanisme daarvan worden verklaard door analyse van de determinanten persoonskenmerken, de eigen beleving van gezondheid, inzetbaarheid en operationele inzet?"

\subsection{Materiaal en methoden}

\subsubsection{Populatie en procedure}

Twee studiegroepen werden samengesteld. Daarbij werden deelnemers uit groep éen gekeurd volgens het ABOHZIS-systeem ("ABOHZIS") en deelnemers uit groep twee volgens het BMEKL-systeem ("BMEKL"). Tussen 22 september en 16 oktober 1998 zijn 863 kandidaten gekeurd, waarbij randomjsatie plaatsvond door iedere week van keuringssysteem te wisselen (figuur 18). Dit leidde tot de uiteindelijke samenstelling van twee onderzoeksgroepen van in totaal 352 personen, waarvan 166 in de ABOHZIS-studiegroep en 186 in de BMEKL-studiegroep. Uit figuur 18 blijkt de onderzoeksopzet, evenals de exclusiecriteria (een aanvullend, niet in figuur 18 vermeld exclusiecriterium was een arbeidsovereenkomst wan onbepaalde duur, de zgn. militair "BOT"). 


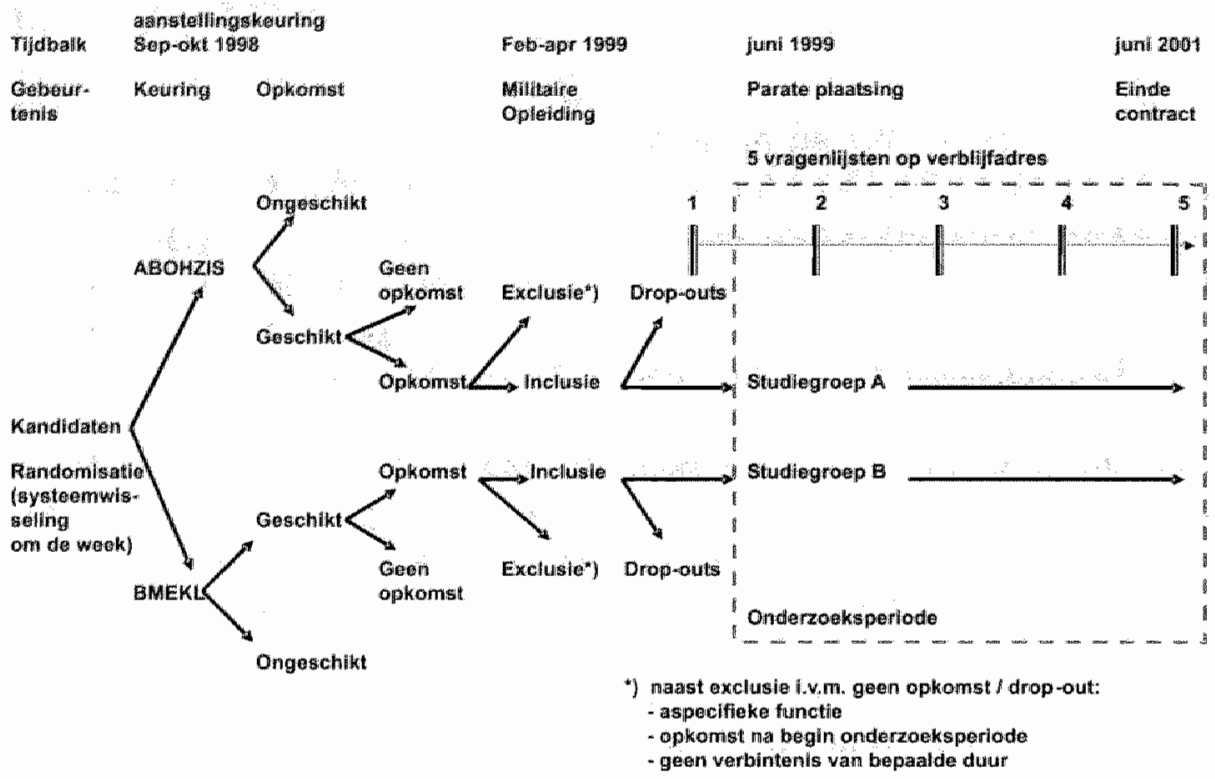

Figuur 18: De onderzoeksopzet voor dit hoofdstuk.

Kandidaten, gerandomiseerd gekeurd en in twee studiegroepen verdeeld na opkomst, worden gedurende twee jaar (periode wan paratstelling) gevolgd. Daarbij wordt halfjaarlijks gebruik genaakt van een vragenlijst.

\subsubsection{Informatie}

Gegevens werden gebruikt uit de keuringsdossiers van de studiegroepen van de centraal beheerde personeelsgegevens. Gegevens inzake de medische consumptie werden ontleend aan zowel de interne (binnen de KL) gebruikte verrichtingenadministratie als bij de ziektekostenverzekeraar.

In totaal werd gebruik gemaakt van de volgende gegevens: keuringsgegevens, exitinterviews van vroegtijdige dienstverlaters, plaatsings- en persoonsgegevens, verzuimgegevens, gegevens afkomstig van eventuele pensioenkeuringen, overplaatsingen op sociale of medische indicatie, de interne geneeskundige verrichtingenadministratie en declaraties bij de ziektekostenverzekeraar. Voorts werd aan iedere deelnemer gevraagd om halfjarlijks een vragenlijst in te vullen en terug te sturen, vanaf het begin van de onderzoeksperiode en vervolgens elke 6 maanden gedurende twee jaar. De gehanteerde vragenlijst was gebaseerd op de klassieke "groene vragenlijst" die lang is gebruikt voor het periodiek arbeidsgezondheidkundig onderzoek (PAGO) en vrijwel op dezelfde wijze geclusterd[5, 6] (tabel 26). Die groene vragenlijst bestond zelf uit twee onderdelen: het onderdeel gezondheidsbeleven (in deze vragenlijst clusters 3, 4, 5 en 6) en het 
onderdeel werkbeleven (in deze vragenlijst clusters 8 tot en met 13). Hieraan waren voor de vragenlijst van dit onderzoek 8 clusters toegevoegd: twee ter controle van elders verkregen gegevens (clusters 1 en 2), één voor het beoordelen van de medische consumptie (cluster 7 ), en vier clusters om de uit het FIS ontleende BMEKL-vragen in te plaatsen[7] (14 tot en met 17). Het achtste nieuwe cluster - 18 - bevatte de omzetting van de specifieke militaire beoordelingspunten naar vragen. Alle vragen vanaf cluster 3 waren dichotoom. Positieve reacties telden voor 1 punt, negatieve voor 0 punten. Bij de vragen uit de clusters $3 \mathrm{t} / \mathrm{m} 7$ werd specifiek naar de situatie van het laatste half jaar gevraagd.

\subsubsection{Effectvariabelen}

Inzetbaarheid. Per kandidaat is over de onderzoeksperiode het aantal (kalender-) dagen inzetbaarheid bepaald door aftrek van het antal dagen ziekteverzuim of andere vormen van arbeidsverzuim, zoals beperkte operationele inzetbaarheid door blessures, vastgesteld door een arts. Hierbij bleek dat her klassieke ziekteverzuim $95 \%$ van het total uitmaakte. Op deze wijze kon de zuivere inzetbaarheid (het aantal kalenderdagen dat een militair operationeel had kunnen worden ingezet) worden bepaald.

Medische consumptie. De medische eerstelijns consumptie is berekend door alle eerste lijns consulten te rekenen naar het gemiddeld over de onderzoeksperiode geldende CTG-tarief $(€ 17,92)$. De overige gemaakte en gedeclareerde ziektekosten zijn bij de ziektekostenverzekeraar opgevraagd.

\subsubsection{Statistiek}

Om relaties tussen de effectvariabelen en de overige variabelen te onderzoeken zijn multiple lineaire regressieanalyses uitgevoerd. Ondat sprake was van twee effectvariabelen zijn twee series anallyses uitgevoerd. Eerst zijn multiple lineaire regressie analyses verricht met dagen inzetbaarheid als aflonkelijke variabele en keuringssysteem als vaste onafhankelijke variabele, achtereenvolgens samen met de volgende onafhankelijke variabelen: leeftijd, gezinsstructuur, geslacht, demografische herkomst (stedelijk of platteland), rookgewoontes (sigaretten of niet), civiele schoolopleiding, fysieke opleidbaarheid, vetpercentage, maximaal vermogen bij de fietsergometrie in watt $/ \mathrm{kg}$ lichaamsgewicht, de ter keuring gevonden medische bijzonderheden en een aantal uitkomstvariabelen zoals platsing, soort functie en het feit of men al dan niet operationeel voor (vredes-) missies is uitgezonden.

Deze regressie analyses zijn vervolgens herhaald, maar nu met medische consumptie als onafhankelijke variabele in plaats van dagen inzetbaarheid. 


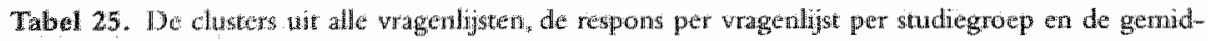
delde score van de chusters per studiegroep.

\begin{tabular}{|c|c|c|c|c|c|c|c|c|c|c|c|c|}
\hline \multirow{3}{*}{\multicolumn{2}{|c|}{$\begin{array}{l}\text { Vrageligst ir } \\
\text { Respons / studiegroep } \\
\text { (A)BOHZIS / (B)MEKL }\end{array}$}} & \multirow{4}{*}{ \# } & \multirow{2}{*}{\multicolumn{2}{|c|}{$\begin{array}{l}1 \\
\text { Nulneting } \\
\text { Scone }\end{array}$}} & \multirow{2}{*}{\multicolumn{2}{|c|}{$\begin{array}{l}\frac{2}{6} \text { maand } \\
\text { score }\end{array}$}} & \multicolumn{2}{|c|}{12 mand } & \multicolumn{2}{|c|}{$18^{\mathrm{e}}$ maand } & \multicolumn{2}{|c|}{$\begin{array}{l}5 \\
24^{e} \text { matand }\end{array}$} \\
\hline & & & & & & & \multicolumn{2}{|c|}{ Score } & \multicolumn{2}{|c|}{ Score } & \multicolumn{2}{|c|}{ Scone } \\
\hline & & & \multirow{3}{*}{$\begin{array}{l}\mathrm{A} \\
75 \%\end{array}$} & & & & A & $\mathrm{B}$ & A & B & A & $\mathrm{B}$ \\
\hline Resp & poris & & & & & & $55 \%$ & $62 \%$ & $4.4 \%$ & $57 \%$ & $42 \%$ & $48 \%$ \\
\hline \multicolumn{9}{|c|}{$\mathrm{Nr}$ Clinster } & & & & \\
\hline 3 & $\begin{array}{l}\text { Algementie } \\
\text { gezondheid }\end{array}$ & 3 & 2,9 & 3,0 & 2.8 & 2,8 & 2.7 & 2,8 & 2,7 & 2,6 & 2,7 & 2.8 \\
\hline 4 & Bewegingrapparat & 8 & 7,5 & 7.6 & 7,0 & 7,0 & 6,8 & 7,0 & 6,6 & 6,8 & 6,8 & 7,0 \\
\hline 5 & Keel, neus en oor & 3 & 2.5 & 2,5 & 2,6 & 2,6 & 2,6 & 2,6 & 2,6 & 2,6 & 2,6 & 2,6 \\
\hline 6 & Stress & 4 & 3,8 & 3,8 & 3,9 & 3,9 & 3,7 & 3,8 & 3.7 & 3,9 & 3,8 & 3,8 \\
\hline 7 & Medische consumptio & $e 8$ & 5,7 & 5,8 & 5,6 & 5,9 & 5,8 & 5,8 & 5.7 & 5,8 & 5,6 & 5,8 \\
\hline $8 / 9$ & $\begin{array}{l}\text { Talakomschrijuing / } \\
\text { Werkorganisatie }\end{array}$ & 10 & 8.8 & 9.1 & 7,9 & 7,8 & 7,6 & 7,4 & 6.9 & 6,8 & 7,4 & 7,3 \\
\hline 10 & Siumenwerking & 5 & 4,3 & 4,4 & 4,3 & 4,1 & 4,0 & 4,0 & 3,8 & 3,8 & 3,8 & 3,9 \\
\hline 11 & Toekomstperspectef & 5 & 4.2 & 4,2 & 4,0 & 4,0 & 3,7 & 3,8 & 3.6 & 3,2 & 3,7 & 3,7 \\
\hline 12 & Duidelijkheid & 3 & 2.7 & 2,7 & 2,4 & 2,5 & 2,4 & 2,5 & 2,3 & 2,3 & 2,2 & 2,3 \\
\hline 13 & Privế & 3 & 2,4 & 2,6 & 2.5 & 2,6 & 2,5 & 2,6 & 2,4 & 2,5 & 2,4 & 2,5 \\
\hline 14 & $\begin{array}{l}\text { FIS-beweging- } \\
\text { sapparat }\end{array}$ & 16 & 15,1 & 15.3 & 15,0 & 15,2 & 14.8 & 15.0 & 14,8 & 15,2 & $1,4,9$ & 15,4 \\
\hline 15 & $\begin{array}{l}\text { Fysisch-chemisch, } \\
\text { buten }\end{array}$ & 8 & 7,5 & 7,6 & 7,4 & 7,7 & 7,4 & 7.7 & 7.6 & 7,7 & 7,6 & 7,8 \\
\hline 16 & $\begin{array}{l}\text { Zintuigen/ } \\
\text { veiligheids }\end{array}$ & 4 & 3,8 & 3,9 & 3,8 & 3,8 & 3,7 & 3,7 & 3,7 & 3,7 & 3.7 & 3,7 \\
\hline 17 & Mis-Pychisch & 13 & 12,1 & 12,4 & 12.2 & 12,4 & 12,0 & 12,5 & 12,1 & 12,3 & 12,2 & 12,8 \\
\hline 18 & $\begin{array}{l}\text { Militaire } \\
\text { beoordelingsptroten }\end{array}$ & 15 & 14,2 & 14,3 & 14,0 & 14,3 & 13,8 & 14,1 & 13,8 & 14,2 & 13,8 & 14,3 \\
\hline
\end{tabular}

A: antal wagen / cluster, A: ABOHZIS, B: BEMKL, FIS: vragen ontlecnd an het FIS.

Van alle vragenlijsten is per studiegroep de respons berekend, van alle clusters uit elke vragenlijst is per studiegroep de gemiddelde uitslag berekend, zoals weergegeven in tabel 25.

Voorafgaand aan verder onderzoek is Crohnbachs' alfa van elk cluster uit de vragenlijsten bepaald. Uit tabel 26 blijkt dat de meeste clusters voldeden aan de eis dat de alfa tenminste 0,50 moet zijn, behoudens enkele clusters uit de eerste vragenlijst en cluster 5 (KNO) uit de tweede. Alleen de clusters 12 "Duidelijk- 
heid" (drie vragen) en 16 "Zintuigen/veiligheid" (vier vragen) voldeden stelselmatig niet aan deze eis. Uit vier clusters $(3,4,7$ en 17$)$ is stelselmatig dezelfde enkele vraag verwijderd om tot een alfa $\geq 0,50$ te komen, om diezelfde reden zijn de clusters 8 en 9 gecombineerd. Om de clusters met statistisch significante associatie met inzetbaarheid en/of medische consumptie te selecteren werden bivariate lineaire regressie analyses uitgevoerd met achtereenvolgens inzetbaarheid en medische consumptie als afhankelijke variabele, waarbij het keuringssysteem samen met telkens een enkel cluster de onafhankelijke variabelen vormen.

Vervolgens werden twee multiple lineaire regressie anallyses uitgevoerd met één van beide effectvariabelen als aflankelijke variabele en de geselecteerde clusters plus keuringssysteem als onafhankelijke variabelen. Een p-waarde van minder dan 0,05 werd als statistisch significant beschoumd. Alle analyses zijn uitgevoerd met behulp van SPSS versie 10.0.

\subsection{Resultaten}

\subsubsection{Uitkomsten van het voorgaande onderzoek op hoofdlijnen}

In totaal werden in de ABOHZIS-groep 399 kandidaten gekeurd, waarvan 304 geschikt werden bevonden (tabel 27). Hiervan kwamen 243 als Beroepsmilitair Bepaalde Tijd (BBT) op. Op grond van de exclusiecriteria bleef darvan een studiegroep van 166 kandidaten over. Voor de BMEKL-groep werden 464 kandidaten gekeurd, waarvan 341 geschikt werden verklaard; hiervan kwamen $270 \mathrm{BBT}$-ers op, op grond van de exclusiecriteria resulterend in een studiegroep van186 kandidaten.

Van de vroege drop-outs werd op grond van verschillende informaticbronnen (uitslagen van de exitinterviews, het achterwege laten van ingediende claims) aangenomen dat hun vertrek op niet-medische gronden berust. In het begin van de onderzoeksperiode bleken persoonskenmerken (leeftijd, gesllacht, gezinssamenstelling, demografische herkomst, schoolopleiding, rookgewoonten) noch de keuringsgegevens (gewicht, lengte, medische bijzonderheden, vetpercentage, fysiek prestatievermogen) statistisch significant te verschillen tussen beide studiegroepen. Tijdens de onderzoeksperiode bleken statistisch significante verschillen te zijn opgetreden tussen beide studiegroepen qua indeling naar gevechts- of gevechtsondersteunende functie $(p=0,02)$, het aantal dagen inzetbaarheid (gemiddeld 648 dagen voor de BMEKL-groep tegenover 612 voor de ABOHZIS-groep; $p=0,02$ ) en de medische consumptie (gemiddeld $€ 396$ tegenover $€ 746 ; p=0,05)$. 
Tabel 26. De cluskerindeling wan de gebrukte wrageniligst, tezmen mett de herkomst wan de vragen, respons en Crohnbachis "alfa van de clusters van alle wageniljstern.

\begin{tabular}{|c|c|c|c|c|c|c|c|}
\hline & \multirow[t]{2}{*}{ Respons } & Enquếte & $\begin{array}{l}1 \\
70 \% \%\end{array}$ & $\begin{array}{l}2 \\
69 \%\end{array}$ & $\begin{array}{l}3 \\
58 \%\end{array}$ & $\begin{array}{l}4 \\
49 \%\end{array}$ & $\begin{array}{l}5 \\
46 \%\end{array}$ \\
\hline & & $\begin{array}{l}\text { Aantint } \\
\text { vragent }\end{array}$ & Allifa & Alfa & Alfa & Alfat & Alfa \\
\hline $\mathrm{Nr}$ & Cluster & & & & & & \\
\hline 3 & Algemene gezondheid * & 3 & 0,61 & 0,63 & 0,64 & 0,61 & 0,74 \\
\hline 4 & Bewegongsapparat * & 8 & 0,62 & 0,66 & 0,62 & 0,71 & 0,62 \\
\hline 5 & KNO * & 3 & 0,46 & 0.48 & 0,55 & 0,55 & 0,53 \\
\hline 6 & Stress * & 4 & 0,29 & 0,73 & 0,56 & 0,71 & 0,61 \\
\hline 7 & Medische Consumptie & 8 & 0,62 & 0,65 & 0,72 & 0,70 & 0,70 \\
\hline $8 / 9(1)$ & $\begin{array}{l}\text { Takinhoud/ } \\
\text { Werkorganisatie * }\end{array}$ & 10 & 0,52 & 0,56 & 0,58 & 0,66 & 0,65 \\
\hline 10 & Samenwerking * & 5 & 0,54 & 0,68 & 0.54 & 0,60 & 0,62 \\
\hline 11 & Tockomstperspecticf & 5 & 0,50 & 0,50 & 0.65 & 0,70 & 0,68 \\
\hline 12 & Dundeligkheid ts & 3 & 0,34 & 0,34 & 0,31 & 0,4 & 0,36 \\
\hline 13 & Privé * & 3 & 0,52 & 0,59 & 0,44 & 144 & 0,51 \\
\hline 14 & FIS-bewegingsapparaat * & ${ }^{*} 16$ & 0,60 & 0,87 & 0,86 & 0,89 & 0,88 \\
\hline 15 & $\begin{array}{l}\text { Fysisch-chemisch, buiten } \\
\star \star\end{array}$ & 8 & 0,35 & 0,81 & 0,81 & 0,59 & 0,67 \\
\hline 16 & Zintugen/velighed ** & 4 & 028 & 0109 & 0,12 & 021 & 0,08 \\
\hline 17 & FIS-psychisch $\star \star$ & 13 & 9,4 & 0,79 & 0,55 & 0,79 & 0,76 \\
\hline 18 & $\begin{array}{l}\text { Militaire } \\
\text { beoordelingspunten ** }\end{array}$ & 15 & 0,12 & 0,69 & 0,59 & 0,61 & 0,66 \\
\hline
\end{tabular}

Toelichting: De grijs gearceende chusters voldoen niet an de eis dat de alfå tenminste 0,50 moet zijn. (1): Op grond van de alfas zijn de clusters 8 en 9 gecombineerd. De met gemarkeerde clusters zijn afkomstig wit het PAGO en de met *t gentarkeerde zijn door de onderzocker ontwikkeld, respectievelijk ondeend asn her FIS.

\subsubsection{Analyse persoonskenmerken en uitkomstvariabelen}

Uit multiple lineaire regressie analyses met dagen inzetbaarheid en medische consumptie als athankelijke variabelen en persoonskenmerken en uitkomstvariabelen als onathankelijke variabelen bleek dat uitgezonden militairen statistisch significant meer dagen inzetbaar waren dan niet uitgezonden militairen (tabel 27). Schoolopleiding bleek geen invloed te hebben $(p=0,06)$. De $p$-waarde van het keuringssysteem bleef $<0,05$. 
Tabel 27. Multiple lineare regressie analyse nar keuringsystecen on de wentude thitzending,

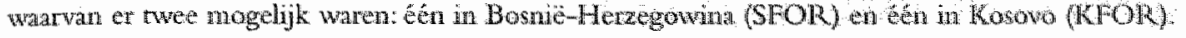

\begin{tabular}{|c|c|c|c|c|}
\hline \multirow[t]{2}{*}{ Onafllankelijke variabelen } & \multicolumn{4}{|c|}{ Afhankelijke variabele: Dagen inzetbarheid } \\
\hline & Bèt: Coëficient & Standarat fout & Puwarade & $\mathrm{R}^{2}$ \\
\hline Keuringssysteem & 118 & 16 & $<0,01$ & \\
\hline \multicolumn{5}{|l|}{ (BMEKL wS ABOHZIS) } \\
\hline \multicolumn{5}{|l|}{ Type uitzending versus } \\
\hline \multicolumn{5}{|l|}{ Overige typen uitzending } \\
\hline Geen uirzending & 510 & 46 & $<0,01$ & \\
\hline SFOR & 280 & 48 & 0,01 & \\
\hline \multirow[t]{2}{*}{ KFOR } & 250 & 51 & 0,04 & \\
\hline & & & & 0,16 \\
\hline
\end{tabular}

Toelichting: $\mathrm{R}^{2}$ staat woor de verklaarde variantie.

\subsubsection{Enquêtes}

Alleen de volledig ingevulde vragenlijsten werden meegeteld. Dit resulteerde in een respons van gemiddeld 2,9 van de 5 lijsten $(2,9 \pm 1,6)$. In totaal reageerden 28 personen nooit, 61 reageerden eenmalig (vooral aan het begin), 60 reageerden tweemaal, 48 driemaal, 79 viermaal en 76 vijfmaal. Tussen beide studiegroepen zat qua respons per vragenlijst eenmaal een statistisch significant verschil (vragenlijst 4 , tabel 25), de respons daalde van $70 \%$ naar $46 \%$ (tabel 25 ).

Bij lineaire regressie analyses met inzetbaarheid als afhankelijke variabele en het keuringssysteem met telkens één van de clusters als onafhankelijke variabelen komt een statistisch significante associatie $(\mathrm{p}<0,05)$ nar voren tussen inzetbaarheid en de clusters Algemene gezondheid. (3), Bewegingsapparaat. (4), Medische consumptie (7) en Militaire beoordelingspunten (18).

Vervolgens is multiple lineaire regressie analyse uitgevoerd met al deze clusters per vragenlijst tezamen en het keuringssysteem als onafhankelijke variabelen en met dagen inzetbaarheid als afhankelijke variabele. Daaruit bleek (tabel 28) dat het cluster Militaire beoordelingspunten (18) bij drie enquêtes statistisch significante associatie vertoont met de inzetbaarheid, voor de clusters Medische consumptie (7) en Algemene gezondheid. (3) is dit elk twee maal het geval, voor de beide clusters over het bewegingsapparaat ( 4 en 14) is dit elk eenmaal het geval. De p-waarde van het keuringssysteem bleef bij deze toetsing boven de 0,05 .

Bij herhaling van de lineaire regressie analyse zoals hierboven vermeld, maar nu met medische consumptie in plaats van dagen inzetbaarheid als aflankelijke 
Tabel 28. Vesultaten van de nutuple lineare regressie andyse net dagen inzetbaarhed als afhankelike variabele cr bet keuringssystem en de clusters als onathankelijke variabelen.

\begin{tabular}{|c|c|c|c|c|c|}
\hline Enquêtu & Cluster & $\begin{array}{l}\text { Beta } \\
\text { Coefficient } \\
\text { (dagen) }\end{array}$ & $\begin{array}{l}\text { Standaardfout } \\
\text { (dagen) }\end{array}$ & P-watde & $R^{2}$ \\
\hline \multirow[t]{4}{*}{2} & Keuringsysteem & 23 & 15 & 0,07 & \\
\hline & $\begin{array}{l}\text { Cluster } 7 \text { : medische } \\
\text { consumptie } 2\end{array}$ & -15 & 4 & 0,02 & \\
\hline & $\begin{array}{l}\text { Cluster 18: militaire } \\
\text { punten } 2\end{array}$ & -43 & 6 & $<0,01$ & \\
\hline & & & & & 0,14 \\
\hline \multirow[t]{5}{*}{3} & Keuringsysteem & -29 & 15 & 0,06 & \\
\hline & $\begin{array}{l}\text { Cluster } 3 \text { : algemene } \\
\text { gezondheid } 3\end{array}$ & -.35 & 11 & $<0,01$ & \\
\hline & $\begin{array}{l}\text { Cluster 4: } \\
\text { bewegingsapparatat } 3\end{array}$ & -26 & 6 & $<0,01$ & \\
\hline & $\begin{array}{l}\text { Cluster 18: militaire } \\
\text { punten } 3\end{array}$ & -37 & 7 & $<0,01$ & \\
\hline & & & & & 0,23 \\
\hline \multirow[t]{4}{*}{4} & Keuringssystecm & -18 & 19 & 0,41 & \\
\hline & $\begin{array}{l}\text { Cluster 3: algenuene } \\
\text { gezondheid } 4\end{array}$ & -60 & 7 & 0,01 & \\
\hline & $\begin{array}{l}\text { Cluster 18: militaire } \\
\text { punten } 4\end{array}$ & -37 & 7 & $<0,01$ & \\
\hline & & & & & 0,21 \\
\hline \multirow[t]{4}{*}{5} & Ketringssystecm & -7 & 20 & 0,54 & \\
\hline & $\begin{array}{l}\text { Cluster } 7: \text { medische } \\
\text { consumptie } 5\end{array}$ & -21 & 6 & 0,01 & \\
\hline & $\begin{array}{l}\text { Cluster 14: } \\
\text { Fis-bewegingsapparatt } 5\end{array}$ & -20 & 9 & $<0,01$ & \\
\hline & & & & & 0,20 \\
\hline
\end{tabular}

Alleen de clusters met cen lage p-warde zijn weergegeven, $\mathrm{R}^{2}$ stat woor de werkJaarde variantie.

variabele bleek vaak sprake van een statistisch significante associatie tussen de clusters Stress (6), Samenwerking (10), FIS-bewegingsapparaat (14), FIS-fysisch-chemisch (15), FIS-psychisch (17) en Militaire beoordelingspunten (18) en medische consumptie.

Hierna is opnieuw multiple lineaire regressie analyse uitgevoerd zoals eveneens hierboven weergegeven, maar met medische consumptie in plaats van dagen 
Tabel 29. De resultaten van de multuple lineare regressie anslyse met medische consumpte als athankelijke variabele en het keuringsysteen en de clustens als onafhankelijke variabelen.

\begin{tabular}{|c|c|c|c|c|c|}
\hline \multirow[t]{2}{*}{ Enquête } & \multirow[t]{2}{*}{ Cluster } & \multirow{2}{*}{$\begin{array}{l}\text { Bètaw } \\
\text { coêfficiënt } \\
€\end{array}$} & \multirow{2}{*}{$\begin{array}{l}\text { Stondaandfout } \\
E\end{array}$} & \multirow[t]{2}{*}{ P-wande } & \multirow[t]{2}{*}{$R^{2}$} \\
\hline & & & & & \\
\hline \multirow[t]{4}{*}{1} & Keuringsysteem & -358 & 217 & 0,10 & \\
\hline & Cluster 9: samenwerking 1 & -470 & 114 & $<0,01$ & \\
\hline & $\begin{array}{l}\text { Chuster 14: } \\
\text { Fis-bewegingsapparat ! }\end{array}$ & -184 & 85 & 0,03 & \\
\hline & & & & & 0,10 \\
\hline \multirow[t]{3}{*}{2} & Keuringssysteem & -351 & 216 & 0.10 & \\
\hline & $\begin{array}{l}\text { Chuster } 15 \text { : } \\
\text { FIS-fysisch-chemisch } 2\end{array}$ & -431 & 107 & $<0,01$ & \\
\hline & & & & & 0,10 \\
\hline \multirow[t]{5}{*}{3} & Keuringssysteem & -190 & 168 & 0,29 & \\
\hline & Cluster 6: Stress 3 & -396 & 197 & 0,03 & \\
\hline & $\begin{array}{l}\text { Cluster 15: } \\
\text { FIS-fysisch-chenusch } 3\end{array}$ & -257 & 133 & 0,01 & \\
\hline & Cluster 17: FIS-psychisch 3 & -212 & 92 & 0,01 & \\
\hline & & & & & 0,15 \\
\hline \multirow[t]{5}{*}{4} & Ketringssysteem & -136 & 222 & 0,33 & \\
\hline & Cluster 4: bewegingsapparaat 4 & -220 & 97 & 0,03 & \\
\hline & Cluster 5: KNO 4 & -387 & 74 & 0,01 & \\
\hline & Clnster 18: militaire punten 4 & -407 & 113 & $<0,01$ & \\
\hline & & & & & 0.31 \\
\hline \multirow[t]{4}{*}{5} & Keuringsystecm & -350 & 271 & 0,61 & \\
\hline & Cluster 17: FIS-psychischt 5 & -520 & 150 & $<0,01$ & \\
\hline & Cluster 18: miliaire punten 5 & -340 & 113 & $<0,01$ & \\
\hline & & & & & 0,28 \\
\hline
\end{tabular}

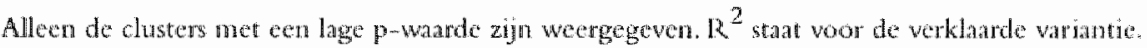

inzetbaarheid als afhankelijke variabele (tabel 29). Uit deze analyse bleek dat de volgende clusters alle in twee van de vijf vragenlijsten een statistisch significante associatie $(p<0,05)$ met medische consumptie vertoonden: Stress (6), FIS-fysisch-chemusch (15), FIS-psychisch (17) en Militaire beoordelingspunten (18). 


\section{3 .4 (Non) respons}

Uit non-responsie analyse bleek dat kandidaten niet responderen indien zij zijn afgekeurd, niet zijn opgekomen of reeds vroeg tijdens de militaire opleiding zijn vertrokken. Ook nadien bleek dat diegenen die uit dienst vertrekken, daarna niet langer reageren. Qua leeftijd, schoolopleiding of keuringssysteem zit er geen statistisch significant verschil tussen de groepen respondenten en non-respondenten, wel naar geslacht (meer vrouwen non-respondent).

Nadere (multiple lineaire regressie) analyse (inzetbaarheid als afhankelijke variabele en het aantal malen respons als onafhankelijke variabele) toonde aan dat diegenen die nooit reageren op de vragenlijst $(\mathrm{p}<0,01)$ of slechts eenmallig $(\mathrm{p}=$ $0,02)$ statistisch significant minder dagen inzetbaar zijn geweest dan de overige respondenten. Tijdens deze analyse bleef de $\mathrm{p}$-waarde van het keuringssysteem relatief gering $(\mathrm{p}=0,09)$. Voor de medische consumptie bleek het aantal malen response niet van belang $(\mathrm{p}=0,40)$. Op grond hiervan is vervolgens nagegaan of tussen de beide te onderscheiden groepen (non-responders plus eenmalige responders versus de overigen) ten aanzien van vermelde persoonskenmerken, keuringsgegevens en uitkomstvariabelen sprake was verschillen. Alleen de schoolopleiding van diegenen die meerdere malen op de vragenlijst reageerden, bleek statistisch significant hoger te liggen dan die van de anderen $(p=0,02)$.

\subsection{Beschouwing}

In de door de keurend arts geregistreerde persoonskenmerken zijn geen factoren van invloed te vinden op de inzetbaarheid of medische consumptie. Wel werd een aantal andere factoren gevonden, geassocieerd met de inzetbaarheid of medische consumptie.

Het al (positief) dan niet (negatief) operationeel worden uitgezonden is een met inzetbaarheid geassocieerde factor. Een hogere respons op de vragenlijst gekoppeld aan een hogere schoolopleiding - is eveneens een factor van invloed. Ook het eigen beleven van de gezondheid, het bewegingsapparaat en de mate warin gebruik wordt gemaakt van medische instanties is van invloed; deze invloed is vermoedelijk tijdelijk (voor periodes van telkens een half jaar, gelet op de vraagstelling). Hoe meer men zichzelf in staat acht tot het uitvoeren van specifieke militaire taken, des te groter is het antal dagen inzetbaarheid.

Anders dan bij inzetbaarheid wordt medische consumptie uitsluitend door de eigen beleving beïnloed. Factoren die daarbij een rol spelen zijn de mate warin men zichzelf in staat acht tot het ondergaan van meer extreme klimatologische onnstandigheden, de mate waarin men zichzelf psychisch belastbaar acht en - gelijk bij inzetbaarheid - de mate waarin men zichzelf in staat acht tot het verrichten van specifieke militaire taken. 
De directe verklaring voor de relatie tussen respons en inzetbaarheid is thet niveau van de schoolopleiding: hoe hoger die opleiding, des te groter de inzet. Tegelijkertijd ontbreekt de relatie tussen response en medische consumptie. Omdat behalve schoolopleiding geen enkel verschil tussen beide groepen kan worden aangetoond, is de meest waarschijnlijke indirecte verklaring voor de bovenstaande gegevens dat (een gebrek aan) motivatie op de achtergrond speelde, bijvoorbeeld door een hoger verzum te vertonen waarbij geen extrat medische kosten werden gemaakt: Omdat non-respons echter het primaire kenmerk van de ene groep is, kan dit niet met behulp van de vragenlijst worden aangetoond.

Operationele, uitzending voor buitenlandse missies gedurende 6 maanden - een kerntaak van de $\mathrm{KL}$ - is geassocieerd met grotere inzetbaarheid, c.q. een lager verzuim. De meest plausibele verklaringen hiervoor zijn de speciffeke verblijfsomstandigheden en de sociale controle tijdens uitzending. Voor de medische consumptie maakt het niet uit of men al dan niet is uitgezonden. Dit wordt niet veroorzaakt door de verrichtingenregistratie, welke tijdens uitzending gecontinueerd wordt. Bij ernstiger medische problemen tijdens uitzending volgt bovendien repatriëring, waarna verdere ziektekosten in eigen land worden gedeclareerd. Het kan niet worden uitgesloten dat het niet worden uitgezonden een rol heeft gespeeld bij inzetbaarheid: teleurstelling omdat men niet wordt uitgezonden, met meer verzuim als gevolg.

De invloed van clusters uit de vragenlijst op inzetbaarheid en medische consumptie is beperkt van omvang: op een potentiële inzetbaarheid van 731 dagen is de gezamenlijke bètacoëffciënt van de clusters uit de tweede vragenlijst bijvoorbeeld $58 \pm 10$ dagen. Ook bij multiple lineaire regressie analyses met medische consumptie als afhankelijke variabele zijn de bètacoëfficiënten van de betrokken clusters bescheiden van omvang.

In deze studie is onderzoek verricht met als doel het vinden van kemmerken, geassocieerd met het functioneren als militair. Dergelijke kenmerken zijn ook gevonden (figur 19). Daarnaast is een verklaring gezocht voor het feit dat het BMEKL-keuringssysteem rekruten selecteert die een grotere inzetbaarheid en lagere medische consumptie vertonen dan het ABOHZIS-keuringssysteem. Aanwezige blessures worden in beide keuringsystemen door anamnese en lichamelijk onderzoek stellig opgemerkt. Of veel blessures zullen optreden valt niet te voorspellen, evenmin of gebruik van medische zorg zal worden gemaakt. Internationaal wordt te intensieve training beschouwd als een hoofdoorzaak van blessureleed $[8,9,10]$, maar door de fysieke selectic vooraf bij de KL zou de 


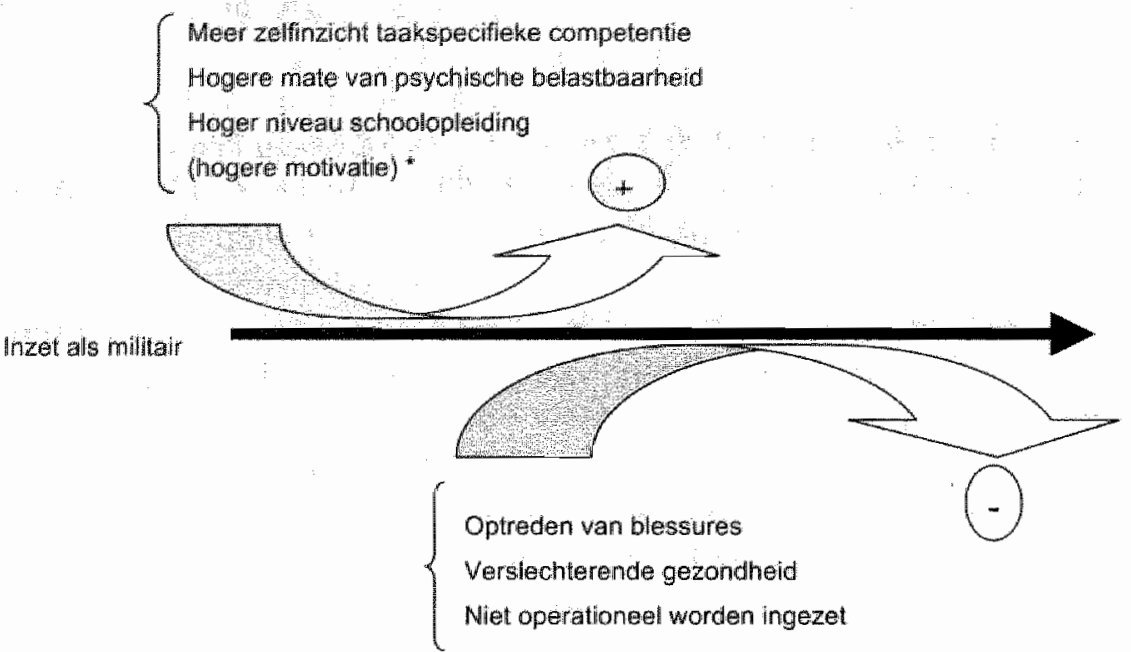

" De factor (hogere motivatie) is gebaseerd op een alanname.

Figuur 19: ter keuring meetbare en inzetbaarheid bevorderende $(+)_{,}$respectievelijk: niet ter keuring meetbare, de inzerbaatheid verlagende $(-)$ factoren van invloed gedurende de contractduur van militairen BBT.

noodzaak voor te intensieve training worden vermeden. Van schoolopleiding was door interne $\mathrm{KL}$-studies al langer een relatie met uitval bekend; bovendien is het vaststellen van de daarvoor aangewezen ondergrens geen medische aangelegenheid. Of militairen al dan niet voor vredesmissies zullen worden uitgezonden wordt evenmin door de medische keuring bepaald.

Het beoordelen of een kandidaat voldoet aan taakspecifieke (militaire) eisen vormt, in tegenstelling tot bij het oude ABOHZIS keuringssysteem, een vast onderdeel van het nieuwe BMEKL keuringssysteem.

Volgens deze redenatie heeft éen factor uit de keuring conform het BMEKL-systeem de meeste invloed gehad op het verschil in inzetbaarheid. Dat betreft de gehanteerde werkwijze (toetsing an de taakspecifieke eisen) voor het beoordelen van de geschiktheid. Voor medische consumptie speelt daarnaast de psychische belastbaarheid een rol. Ook deze belastbaarheid wordt alleen met behulp van het BMEKL-systeem getoetst.

Deze onderzoeksbevindingen komen niet overeen met de theorie dat de invloed van aanstellingskeringen op werknemers gering is, een theorie die vooral is ontstan naar aanleiding van thet onderzoek van De Kort [2]. Voor het feit dat deze bevindingen niet met de heersende theorie overeenkomen, kunnen twee verklaringen worden gegeven. 
Zelfs De Kort erkent dat het gebruik van een anstellingskeuring tanvaardbaar kan zijn als het te vermijden risico groot wordt geacht. Dit is nu precies het geval bij het optreden als militair. Een militair wordt dan ook niet voor een bepaalde functie gekeurd, maar wordt gekeurd on een uiteenlopend scala van taken uit te voeren, met inbegrip van operationele inzet. Het verschil tussen de theorie en de onderzoeksbevindingen zou kunnen zijn gebaseerd op het feit dat dit soort werk - het militaire - uitermate gevarieerd is en veel verschillende risico"s kent, geestelijk zowel als lichamelijk. In geval er sprake zou zijn van minder veeleisende functies zou de vigerende theorie van toepassing blijven.

Een tweede verklaring kan zijn dat de eisen hoger liggen dan de werkelijk vereiste belastbaarheid, waardoor veel feitelijk geschikte kandidaten onterecht worden afgewezen. Deze verklaring lijkt minder waarschijnlijk dan de eerste. Weliswaar bestaat geen gouden standaard, zodat de mogelijkheid niet kan worden uitgesloten, maar tussen beide keuringssystemen zit geen statistisch significant verschil inzake de percentages afgewezen kandidaten. Desalniettemin zow het alsnog zo kunnen zijn dat beide keuringssystemen "te streng keuren".

Samenvattend kan worden geconcludeerd dat in deze studie een aantal factoren is gevonden die van invloed zijn op de inzetbaarheid en de medisch consumptie: schoolopleiding, blessures, operationele inzet en het BMEKL-keuringssysteem zelf. De betere prestatie van het BMEKL-keuringssysteen lijkt deels te kunnen worden toegeschreven aan het vermogen om op taakspecifieke eisen te beoordelen. Maar het primaire mechanisme waarop dit is gebaseerd, blijft verborgen.

\section{Geraadpleegde literatuur}

1. Raad J de, Peters JHM, Groot RP de et al: Modernisering wan het ketringssystem bij de Koninklijke Landmacht; keuringsprotocollen en functioned beoordelen. TBV 2000; $8: 110$ 115.

2. Kort WLAM de: Personnel selection through prememploynent medicals. Ansterdan, 1993.

3. Klein Hesselink DJ, Kruidenier HJ, Veerman TJ et al: Afwezigheid verklard. Een literatuurstudie naar determinanten van ziekteverzuim en arbeidsongeschiketheid. NIA. Amsterdan, 1993.

4. Broersen JPJ, Weel ANH, Dijk FHH van: Periodiek Bedrijfsgeneeskundig Onderzoek; midde! en maatstaf. Anisterdam, 1989.

5. Putten DJ van, Marcelissen $F G H$, Winter $C$ de: De vragenlijst voor PBGO 1-4. Achtergronden woot het gebruik ervan. Het wijzigen van antwoorden door bedijifsartsen. Methoden woor gebruik wan referentiegegevens. TSG 1988; 66:115-120,143-147.

6. Putten DI van: De vragenlijst voor $\mathrm{PBGO}$, voorstellen tot wijziging van de vagenlijst. Leiden, NIPG/TNO, 1989.

7. Raad J. de, Peters JHM, Nijhuis FJM: De kwaliteit van een keuringssystem, Een pilot-onderzoek naar de kwaliteit van ther keuringssysteem wolgens de basismedische eison van de Koninklijke Landmacht. TBV 2000;8:105-109. 
8. Jordan $G, S c h w d h u s$ MP. The incidence of overuse injuries in military recrutes during basic nalicary traning, Mil Med 1994: 159(6):421-426.

9. Alneida SA, Willami KM, Shaffer RA et al: Epidemiological patterns of musculoskeletal injuries and physical training Med Sei Sports Exerc 1999; $31(8): 1176$-1182.

10. Popye RP Herbert R, Kinwan JD et als Predicting attrition in basic military training. Mil Med $1999,164(10): 710-714$ 


\section{7 | Verschillen in inzetbaarheid tussen uitgezonden militairen}

In belangrijke mate overgenomen uit: Raad J de, Nijhuis FJN, Willems JHBM: Difference in fitness for duty between soldiers on a mission. Can these be explained by a difference in the pre-employment assesment? In september 2005 door Military Medicine voor publicatie ingepland. 


\section{1 inleiding en vraagstelling voor dit onderzoek}

In november 1998 is bij de Koninklijke Landmacht (KL) een nieuw keuringssysteem in gebruik genomen, de Basismedische Eisen KL [1] (BMEKL), ter vervanging van het vorige systeem (ABOHZIS). Het nieuwe systeem is gebaseerd op het model "belasting-belastbaarheid" [2]. De functue-eisen voor de militair zijn geoperationaliseerd in 43 beoordelingspunten. Elk beoordelingspunt (zoals "staan" en "lopen", maar ook "vuurwapen hanteren", "scherfwerend vest dragen" en "graven") is voorzien van een norm. Tezamen vormen deze normen de BMEKL. Ze zijn afkomstig van het belastbarheidpatroon van het FIS en specifieke militaire activiteiten. Het oude - diagnosegerichte keuringssysteem verplichtte de keurend arts om ziekten en gebreken te determineren, waarna de uitslag werd bepaald op grond van een vastgestelde lijst met aandoeningen. Er bestonden geen functie-eisen. Bekend was dat dit systeem geen relatie met de feitelijke militaire werkzaamheden vertoonde [3]; er werd. vooral geen rekening gehouden met operationeel optreden tijdens (vredes-)missies. Bij het nieuwe keuringssysteem wordt gekeken of de gevonden medische bijzonderheden tot beperkingen leiden ten opzichte van functie-eisen. Deze functie-eisen zijn geoperationaliseerd in een minimaal vereist operationele functioneringsniveau, dat wel alle feitelijke militaire werkzaamheden omvat. In het ABOHZIS-systeem kon men op grond van een aandoening worden afgekeurd, ongeacht de mate van belastbaarheid; in het BMEKL-systeem kan men geschikt worden verklaard aan de hand van de mate van belastbaarheid, ongeacht de aandoening.

$\mathrm{Na}$ de introductie van het nieuwe systeem is begonnen met de evaluatie ervan. Inmiddels is al onderzoek verricht naar de mate van overeenstemming [4], [5]. Hierbij was ter illustratie de kappa van Cohen [6] 'bij pensioenkeuringen tussen de twee bij dit onderzoek betrokken artsen 0,74 ; bij de anstellingskeuringen werd tussen de verschillende bij dat onderzoek betrokken paren artsen een kappa van Cohen gevonden die varieercle tussen 0,69 en 0,95.

Voorafgaande aan de formele invoering van het nieuwe systeem deed zich de gelegenlyeid voor om beide keuringssystemen naast elkaar te gebruiken bij de aanstellingskeuring, in de wetenschap dat een gouden standaard ontbreekt. Als gevolg daarvan kon een onderzoek worden opgezet om de (lange termijn) effecten van beide keuringssystemen op het aldus gekeurde militair personeel te vergelijken. De hieruit voortgekomen studies onderscheiden zich in tweeërlei

$1 \quad K a p p a=\mathbb{P}_{0}-P_{e} / 1-P_{e}$, warbij $P_{0}$ de wargenomen overeenstemning en $P_{e}$ de toevallige overeenstenming is. 
opzicht van wat tot op heden in Nederland aan onderzoek natar de relevantie van medische aanstellingskeuringen is verricht [7]. Tot nu toe is de relatie tussen keuring enerzijds en uitval op het werk door ziekte of uitstroom natar arbeidsongeschiktheid anderzijds onderzocht. In deze studie is de tegenovergestelde relatie onderzocht: tussen de keuring en de mate waarin de werknemer adequat functioneert. Daamaast is in deze studie ook andacht besteed aan de beleving van de arbeidsomstandigheden door de werknemers zelf.

Om te onderzoeken of tussen beide keuringssystemen verschillen in dagen inzetbaarheid en medische consumptie onder het angenomen personeel zouden optreden, is in de periode $1999-2001$ een gerandomiseerde gecontroleerde studie verricht. Daarbij werd een groep van 352 militairen met een verbintenis van bepaalde duur (Beroeps Bepaalde Tijd, BBT) gedurende een periode van twee jaar gevolgd, nadat zij gerandomiseerd via één van beide keuringssystemen waren goedgekeurd en in twee studiegroepen waren verdeeld [8]. Als maatstaven voor het meten van de effecten op het personeel werden de uitkomstvariabelen medische consumptie en het aantal dagen inzetbaarheid gehanteerd.

Gedurende diezelfde onderzoeksperiode werd halfjarlijks aan de bij het onderzoek betrokken kandidaten een vragenlijst aangeboden. Het doel daarvan was om inzicht te krijgen in het beleven van de gezondheid(-srisico's) door de respondent. Aan die beleving wordt invloed toegeschreven op het effect dat gezondheidsrisico's uitoefenen op de werknemer [9]. Een vragenlijst 'zou aldus de mogelijkheden uitbreiden om na te gaan waar de in het vorige onderzoek gevonden verschillen op berusten.

Eén van de belangrijkste redenen om naar een nieuw keuringssysteen over te gaan was dat het oude systeem onvoldoende rekening hield met de operationele taakstelling. Die taakstelling manifesteert zich in de participatie van internationale missies in het buitenland. Sinds 1992 is de bijdrage van de Nederlandse krijgsmacht aan internationale missies een steeds grotere plats gaan innemen in de algehele taakstelling. Voor dergelijke missies worden eenheden samengesteld die gedurende 4 tot 6 maanden achtereen in het aangegeven inzetgebied operationeel actief zijn. De arbeidsomstandigheden ter plekke zijn afhankelijk van de lokale (militaire, politieke, klimatologische en geografische) omstandigheden en zijn meestal anders dan die in het eigen land.

De militair wordt niet voor een bepaalde functie aangesteld, maar moet alle opgedragen werkzaamheden en diensten verrichten en kan daarbij overal ter wereld onder uiteenlopende arbeidsomstandigheden worden ingezet. De wetgever heeft aangegeven dat deze "multifunctionaliteit" zware fysieke en 
geestelijke eisen aan de militair stelt: Juist daarom stelt de wetgever de krijgsmacht in de gelegenheid om een anstellingskeuring uit te voeren bij aspirant-militairen. De werzwarende arbeidsomstandigheden daarbij zijn de training en de opleiding voot de operationele taakstelling, de cefeningen en de uitzendingen zelf. Op de eigen werkplek - de kazerne - verschillen de arbeidsomstandigheden weinig van die van andere Nederlandse werknemers.

De anstellingskeuring wordt gebruikt voorafgaande aan de indiensttre ding wan militair beroepspersoneel, waar de KL sinds de opschorting van de dienstplicht (1996) nog louter uit bestaat. Naast kaderleden met een verbintenis voor onbepaalde tijd ("BOT") bestaat dit personeel in toenemende mate uit manschappen en kaderleden met een verbintenis voor bepaalde tijd, in de regel voor $2^{1 / 2} \mathrm{jaar}$ ("BBT") . Het eerste half jaar van die verbintenis bestaat uit verschillende opleidingen $^{2}$, waarna een platsing op de definitieve functie volgt. Deze functies kunnen worden onderverdeeld in zogenaamde gevechts- dan wel gevechtsondersteunende functies. Uit intern onderzoek was reeds bekend dat gedurende de opleidingsperiode een uitstroom plaatsvindt van $20-35 \%$. Hiervoor bestaan diverse oorzaken van niet-medische aard: dat men niet de functie heeft gekregen die men wenste, of dat de bedrijfscultuur achteraf toch tegenviel, ofwel dat men het vele buitenwerk (veldoefeningen etc.) onaantrekkelijk vindt. $\mathrm{Na}$ de opleiding is het verloop zeer gering.

Met name het aanstellen van de hierboven vermelde militairen BBT is op participatie aan operationele missies in het buitenland gericht. Niet elke militair BBT wordt echter gedurende de verbintenis effectief operationeel ingezet. Zowel bij een vergelijking van de mate van overeenstemming als van de voorspellende waarde tussen beide keuringssystemen zal er sprake zijn van groepen waarbij een gedeelte operationeel is ingezet en een ander gedeelte waarbij dit niet het geval is. Juist onder operationele onstandigheden zou het verschil tussen beide keuringssystemen in theorie moeten opvallen. Om die reden is nader onderzoek naar verschillen tussen louter uitgezonden militairen uit de hierboven gememoreerde studiegroepen relevant.

Uit het bovenstaande volgt de vraagstelling voor dit onderzoek: "Bestaat er ook een verschil in prognostische waarde tussen beide keuringssystemen ten aanzien van uitsluitend de uitgezonden militairen en zo ja, kan dat worden verklaard

2 Voor manschappen bestaan er qua fysieke belasting twee soorten opleiding, de reguliere en de zwatrdere (en iets langere) voor de Luch tmobiele Brigade. Kaderleden krijgen een opleiding an eigen instituten, fysiek ongeveer vergelijkbar met de zwaarste opleiding voor mantischappen. 
door analyse van de determinanten persoonskenmerken, het beleven wan de eigen gezondheid, de eigen beleving van gezondheid en inzetbaarheid?"

\subsection{Materiaal en methoden}

\subsubsection{Populatie en procedure}

Twee studiegroepen werden samengesteld. Daarbij werden deelnemers uit groep één gekeurd volgens het ABOHZIS-systeem ("ABOHZIS") en deelnemers uit groep twee volgens het BMEKL-systeem ("BMEKL"). Tussen 22 september en 16 oktober 1998 zijn 863 kandidaten gekeurd, waarbij randomisatie plaatsvond door iedere week van keuringssysteem te wisselen. Dit leidde tot de uiteindelijke samenstelling van twee onderzoeksgroepen van in totaal 352 personen, waarvan 166 in de ABOHZIS-studiegroep en 186 in de BMEKL-studiegroep (figuur 20). Uit deze studiegroepen zijn voor dit onderzoek die militairen geselecteerd die volgens hun persoonsgegevens zijn uitgezonden tijdens de onderzoeksperiode. Uiteindelijk bleken van de ABOHZIS-groep 77 (46\%) uitgezonden te zijn geweest, tegenover 84 (45\%) uit de BMEKL-groep (Tabel 30).

Teneinde voor het volgen van de onderzoekspersonen gebruik te kunnen maken van hun persoons- en keuringsgegevens verzochten de keurend artsen alle kandidaten om hun schriftelijke toestemming; die toestemming werd zonder uitzondering verkregen. De kandidaten waren niet op de hoogte van het onderzoek of het feit dat zij gerandomiseerd werden gekeurd. De onderzoeksperiode liep van 1 juni $1999-1$ juni 2001. De redenen voor exclusie waren: ongeschikt verklaring, militairen BOT, plaatsing buiten de $\mathrm{KL}$, geen opkomst / vertrek reeds in de militaire opleiding, opkomst na 1 juni 1999 en atypische functies.

\subsubsection{Informatie}

Informatie werd gehaald uit de keuringsdossiers van de studiegroepen, alsmede van de centraal beheerde personeelsgegevens inzake de studiegroepen. Gegevens over de medische consumptie werden ontleend an zowel de interne (binnen de KL) gebruikte verrichtingenadministratie als bij de ziektekostenverzekeraar.

In total werd gebruik gemaakt van de volgende gegevens: keuringsgegevens, exitinterviews van vroegtijdige dienstverlaters, plaatsings- en persoonsgegevens, verzuimgegevens, gegevens afkomstig van eventuele pensioenkeuringen, overplaatsingen op sociale of medische indicatie, de interne geneeskundige verrichtingenadministratie en declaraties bij de ziektekostenverzekeraar. Voorts werd 


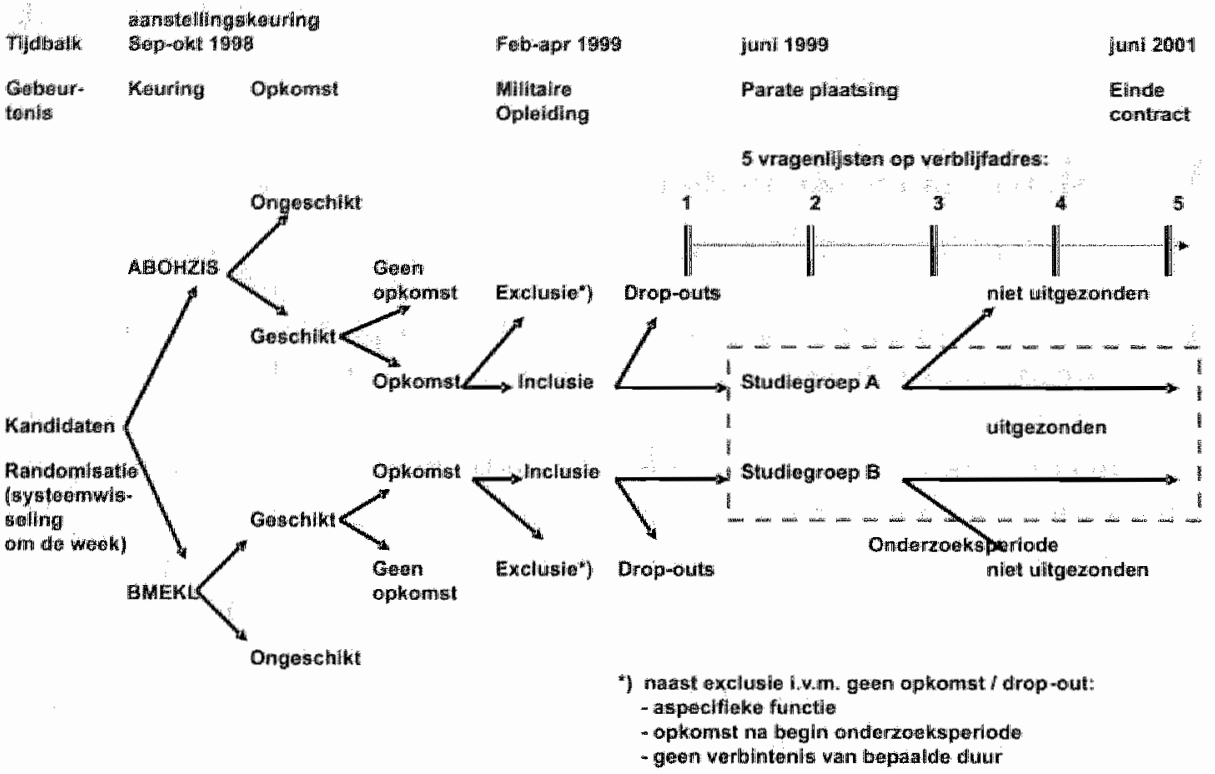

Figuur 20: De onderzoeksopzet woor hoofdstuk 7.

In deze studie worden uitsluitend de uitgezonden militairen, gerandomseerd gekeurd en in twee studiegroepen verdeeld, gevolgd.

Tabel 30. Het verloop van de gekeurde militairen.

\begin{tabular}{|c|c|c|c|c|}
\hline \multirow[b]{2}{*}{ Gekeurd } & \multicolumn{2}{|c|}{ ABOHZIS groep } & \multicolumn{2}{|c|}{ BMEKL groep } \\
\hline & 399 & $100 \%$ & 464 & $100 \%$ \\
\hline Argekeurd & -64 & $16 \%$ & -58 & $13 \%$ \\
\hline Uitwal door fysieke selectix & -31 & $8 \%$ & -65 & $14 \%$ \\
\hline Ouschikt & 304 & $76 \%$ & 341 & $73 \%$ \\
\hline Beroeps Onbepanlde Tijd (BOT) & -8 & $2 \%$ & -17 & $4 \%$ \\
\hline Niat bij KL mare diders & -15 & $4 \%$ & -18 & $4 \%$ \\
\hline Nooit opgekonen & -36 & $9 \%$ & -33 & $7 \%$ \\
\hline Anders ${ }^{\star}$ & -2 & $1 \%$ & -3 & $1 \%$ \\
\hline Berocps Bepalde Tijd (BBT) & 243 & $61 \%$ & 270 & $58 \%$ \\
\hline Te kort in dienst & -75 & $19 \%$ & -80 & $17 \%$ \\
\hline To laat in dichat & -2 & $1 \%$ & -4 & $1 \%$ \\
\hline Sudiegroepen & 166 & $42 \%$ & 186 & $40 \%$ \\
\hline Uitgezonden & 77 & $46 \%$ & 84 & $45 \%$ \\
\hline
\end{tabular}

*): "Anders" stant woor afwijkende militaire functics, zoals geesteljik verzorger en millitaike muzikant. 
Tabel 31. De clusterindeling van de gebruikte vagenlyjs, tezanen met ab herkomist wan de wragen, respons en Crohnbachs" alfa wan de clusters van alle vragenlijsten.

\begin{tabular}{|c|c|c|c|c|c|}
\hline & \multirow{3}{*}{ Respons } & Enquâtre & 2 & \multirow{3}{*}{$58 \%$} & 4 \\
\hline & & \multirow{2}{*}{ Aantal yragen } & \multirow{2}{*}{$\begin{array}{l}69 \% \\
\text { Alf }\end{array}$} & & \multirow{2}{*}{$\begin{array}{l}49 \% \\
\text { Alfa }\end{array}$} \\
\hline & & & & & \\
\hline $\mathrm{Nr}$ & \multicolumn{5}{|l|}{ Cluster } \\
\hline 3 & Algemene gezondheid * & 3 & 0.63 & 0,64 & 0,61 \\
\hline 4 & Bewegingsapparaat * & 8 & 0,66 & 0,62 & 0,71 \\
\hline 5 & $\mathrm{KNO} *$ & 3 & 0,48 & 0,55 & 0,55 \\
\hline 6 & Stress * & 4 & 0,73 & 0,56 & 0,71 \\
\hline 7 & Medische Consumprie * & 8 & 0,65 & 0,72 & 0,70 \\
\hline $8 / 9(1)$ & $\begin{array}{l}\text { Taakinhoud/ } \\
\text { Werkorganisatie * }\end{array}$ & 10 & 0,56 & 0,58 & 0,60 \\
\hline 10 & Samenwerking * & 5 & 0,68 & 0,54 & 0,60 \\
\hline 11 & Toekomstperspectief* & 5 & 0,50 & 0,65 & 0,70 \\
\hline 12 & Duidelijkheid * & 3 & & & \\
\hline 13 & Privé * & 3 & 0,59 & 0,4 & 0,44 \\
\hline 14 & FIS-bewegingsapparant ** & 16 & 0,87 & 0,86 & 0.89 \\
\hline 15 & Fysisch-chemisch, buiten $*$ * & 8 & 0,81 & 0,81 & 0,59 \\
\hline 16 & Zintuigen/ veiligheid tt & 4 & tes & 2 & 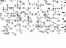 \\
\hline 17 & FIS-psychisch ** & 13 & 0.79 & $0,5,5$ & 0,79 \\
\hline 18 & 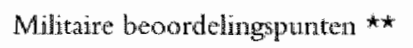 & 15 & 0,69 & 0,59 & 0,61 \\
\hline
\end{tabular}

De grijs gearceerde clusters woldoen niet aan de eis dat de alfa tenminste 0,50 moet zijn. (1): Op grond van de alfa's zijn de clusters 8 en 9 gecombineerd. De nee * genarkectc clusters zijn. afkomstig uit het PAGO en de met "gemarkerde zijn door de onderzocken ontwikkeld, respectievelijk ontleend an het FIS.

aan iedere deelnemer gevragd om halfjaarlijks een vragenlijst in te vullen en terug te sturen, vanaf het begin van de onderzoeksperiode en vervolgens elke 6 maanden gedurende twee jaar.

De gehanteerde vragenlijst was gebaseerd op de klassieke "groene vragenlijst" die lang is gebruikt voor het periodiek arbeidsgezondheidkundig onderzoek (PAGO) en vrijwel op dezelfde wijze geclusterd[10, 11] (tabel 31). Die groene vragenlijst bestond zelf uit twee onderdelen: het onderdeel gezondheidsbeleven (in deze vragenlijst clusters $3,4,5$ en 6) en het onderdeel werkbeleven (in deze vragenlijst clusters $8 \mathrm{t} / \mathrm{m}$ 13). Hieraan waren voor de vragenlijst van dit onderzoek 8 clusters toegevoegd: twee ter controle van elders verkregen gegevens (clusters 1 en 2), één voor het beoordelen van de medische consumptie (cluster 
7), en viet clusters orn de uit het FIS ontleende BMEKL-vragen in te plaatsen[11] (14 tot en met 17). Het achtste nieuwe cluster-18-bevatte de omzetting văn de specifieke militaire beoordelingspunten naar vragen. Alle vragen vanaf cluster 3 waren dichotoom. Bij de vragen uit de clusters 3 tot en met 7 werd specifiek naar de situatie van het laatste half jaar gevraagd.

Vanaf het begin van de onderzoeksperiode ontving de kandidaat deze vragenlijst halfjarlijks, in totaal vijf maal. Positieve reacties telden voor 1 punt, negatieve voor 0 punten.

\subsubsection{Effectvariabelen}

Inzetbarheid. Per kandidaat is over de onderzoeksperiode het aantal (kalender-)dagen inzetbaarheid bepaald door aftrek van het aantal dagen ziekteverzuim of andere vormen van arbeidsverzuim, zoals beperkte operationele inzetbaarheid door blessures, vastgesteld door een arts. Hierbij bleek dat het klassieke ziekteverzuim 95\% van het totaal uitmaakte. Op deze wijze kon de zuivere inzetbaarheid ( het aantal kalenderdagen dat een militair operationeel had kunnen worden ingezet) worden bepaald.

Medische consumptic. De medische eerstelijns consumptie is berekend door alle eerste lijns consulten te rekenen naar het gemiddeld over de onderzoeksperiode geldende CTG-tarief $(€ 17,92)$. De overige gemaakte en gedeclareerde ziektekosten zijn bij de ziektekostenverzekeraar opgevraagd.

\subsubsection{Statistische methoden}

Voor de beoordeling van standaardafwijkingen en betrouwbaarheidsintervallen is voor continue variabelen gebruik gemaakt van de Mann Whitney $U$ test, voor niet-continue variabelen de Pearson Chikwadraattest.

Voorts zijn lineaire regressie analyses (voor de selectie van clusters die inzetbaarheid en/of medische consumptie beinvloedden) en multiple lineaire regressie analyses (mei die geselecteerde clusters) verricht. Voor het analyseren van de relaties tussen de effectvariabelen en de overige variabelen zijn lineaire regressie analyses en multiple lineaire regressie analyses gepleegd. Omdat er sprake was van twee effectvariabelen (inzetbaarheid en medische consumptie) zijn ook twee sets analyses gepleegd. Omdat dit onderzoek zich beperkt tot uitgezonden militairen en omdat deze uitzendingen platsvonden tussen het moment van de tweede en de vierde vragenlijst, zijn alleen deze tweede tot en met de vierde vragenlijst in dit onderzoek gebruikt.

Voorafgaande aan de analyse van de vragenlijsten is Crohnbachs' alfa van elk cluster bepaald. Uit tabel 31 blijkt dat de meeste clusters voldeden aan de eis dat deze alfa tenminste 0,50 moet zijn. Alleen de clusters 12 "Duidelijkheid" (drie 
vragen) en 16 "Zintuigen/veiligheid" (vier vragen) voldeden stelselmatig niet aan deze eis en zijn derhalve buiten beschouwing gelaten. Uit vier clusters $(3,4$, 7 en 17) is stelselmatig een vragg verwijderd on to een alfa $\geq 0,50$ te konen; om diezelfde reden zijn de clusters 8 en 9 gecombineerd.

Om de clusters, geassocieerd met de effectvariabelen, te selecteren zijn lineaire regressie analyses gepleegd waarbij de relatie tussen elk cluster en de effectvariabele één voor één is nagegaan. Hierna werd multiple lineaire regressie analyse gepleegd met alle clusters, waaruit in voorgaand onderzoek (de lineaire regressie analyse) op individuele basis een statistisch significante associatie was gebleken met de effectvariabele. Een p-waarde van minder dan 0,05 werd als statistisch significant beschouwd. Alle analyses zijn met behulp van SPSS 10.0 verricht.

\subsection{Resultaten}

\subsubsection{Uitkomsten van het voorgaande onderzoeken op hoofdlijnen}

In het eerste onderzoek [8] werd een ABOHZIS-studiegroep samengesteld van 166 personen en een BMEKL-studiegroep van 186 personen (tabel 30). Van de vroege drop-outs kon op grond van verschillende informatiebronnen (uitslagen van de exitinterviews, het achterwege laten van ingediende claims) worden aangenomen dat hun vertrek op niet-medische gronden berustte.

In het begin van de onderzoeksperiode bleken persoonskenmerken noch de keuringsgegevens statistisch significant te verschillen tussen beide studiegroepen. Tijdens de onderzoeksperiode bleken statistisch significante verschillen te zijn opgetreden tussen beide studiegroepen qua indeling naar gevechts- of gevechtsondersteunende functie, het aantal dagen inzetbaarheid en de medische consumptie.

Teneinde meer inzicht te krijgen in de oorzaak van de gevonden verschillen werd de associatie tussen deze gegevens en informatie inzake de deelnemers aan het onderzoek (zoals schoolopleiding, uitzending) nader onderzocht [12]. Duarnaast ontvingen de participanten halfjaarlijks een vragenlijst, die grotendeels was gebaseerd op een ("groene vragen-") lijst die voor het periodiek bedrijfsgezondheidkundig onderzoek in ons land werd gehanteerd. Uit dit onderzoek bleek dat de volgende factoren van invloed waren op inzerbaarheid en medische consumptie: opleiding, blessures, operationele inzet (tuitzending) en het keuringssysteem zelf.

\subsubsection{Analyse persoonskenmerken en uitkomstvariabelen}

Bij multiple lineaire regressie analyse met dagen inzetbaarheid als afhankelijke variabele tegenover het al dan niet uitgezonden zijn als onaflankelijke variabele, 


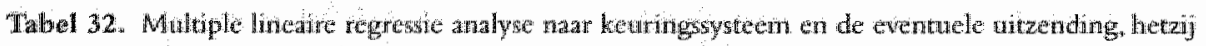
nara Bome-Heregown (SFOR), dan wel nat Kosowo (KFOR).

\begin{tabular}{|c|c|c|c|c|}
\hline \multirow[t]{2}{*}{ Onafhankelijke variabelen } & \multicolumn{4}{|c|}{ Afhanke dijke variabele: dagen inzetbarheid } \\
\hline & Beta coefficiënt & $\begin{array}{l}\text { Standard } \\
\text { Fout }\end{array}$ & P-waarde & $\mathrm{R}^{2}$ \\
\hline $\begin{array}{l}\text { Kewnigsysteem } \\
\text { (BMEKL wS ABOHZIS) }\end{array}$ & 118 & 16 & $<0,01$ & \\
\hline \multicolumn{5}{|l|}{ Type untzending versus } \\
\hline \multicolumn{5}{|l|}{ Overige typen utzending } \\
\hline Geen witzending & -510 & 46 & $<0,01$ & \\
\hline SFOR & 280 & 48 & 0,01 & \\
\hline \multirow[t]{2}{*}{ KPOR } & 250 & 51 & 0,04 & \\
\hline & & & & 0,16 \\
\hline
\end{tabular}

$\mathrm{R}^{2}$ stat woor de verklatarde wariantic.

blijkt dat uitgezonden militairen statistisch significant meer dagen inzetbaar zijn geweest dan diegenen die niet zijn uitgezonden (tabel 32). Uit verdere analyses bleek dat op het gebied van de geregistreerde persoonskenmerken, keuringsgegevens en personeelsgegevens verder geen statistisch significante verschillen tussen wel en niet uitgezonden militairen bestonden.

Vervolgens is onderzocht of tussen de fracties uitgezonden militairen uit beide studiegroepen statistisch significante verschillen bestonden inzake de persoonskenmerken, keuringsgegevens, persoonsgegevens en uitkomstvariabelen. Dit bleek niet het geval met betrekking tot leeftijd $(p=0,51)$, geslacht $(p=0,53)$, demografische herkomst (stad of platteland, $p=0,43$ ), ouderlijke gezinssamenstelling (compleet of niet; $\mathrm{p}=0,55$ ), rookgewoonten (altijd sigaretten; $\mathrm{p}=0,17$ ), schoolopleiding $(p=0,53)$, burgerlijke staat $(p=0,57)$, medische bijzonderheden uit de keuringsgegevens $(p=0,37)$, de fysieke selectietest $(p=0,28)$, definitieve plaatsing na de militaire opleiding $(\mathrm{p}=0,27)$ en eventuele overplaatsingen op social-medische indicaties $(p=0,93)$. In tabel 33 worden de enige drie variabelen weergegeven warin tussen beide fracties uitgezonden militairen wel een statistisch significant verschil bestond. Uitgezonden militairen uit de BMEKL-fractie bleken statistisch significant meer dagen inzetbaar te zijn geweest. Voorts werden in de uitgezonden fractie van de BMEKL-studiegroep statistisch significant meer gevechtsfuncties uitgeoefend dan in de uitgezonden fractie van de $A B O H Z I S$-studiegroep. In de derde plaats zaten in de uitgezonden fractie van de BMKEL-studiegroep statistisch significant meer 
Tabell 33. Utkomistwabelen gedurende de onderzoekspenode:

\begin{tabular}{|c|c|c|c|c|c|c|}
\hline \multirow[b]{2}{*}{ Varrabele } & & \multicolumn{2}{|c|}{ ABOHZLS } & \multicolumn{2}{|l|}{ BMEKL } & \multirow[b]{2}{*}{$\mathrm{p}$} \\
\hline & & $N=77$ & $\%$ & $N=84$ & $\%$ & \\
\hline \multirow{2}{*}{$\begin{array}{l}\text { Indeling op } \\
\text { frnctie }\end{array}$} & Gevechtsfunctie & 27 & 35,0 & 46 & 54,7 & \\
\hline & Gevechtondersteunend & 50 & 65,0 & 38 & 45.3 & 0,01 \\
\hline $\begin{array}{l}\text { Militaire } \\
\text { Opleiding }\end{array}$ & Regulier & 72 & 93,5 & 69 & 82.1 & \\
\hline \multirow[t]{2}{*}{ a) Manschappen } & LMB & 1 & 1,3 & 11 & 13,1 & \\
\hline & Anders & 2 & 2,6 & 2 & 2,4 & \\
\hline b) Kaderleden & KMS & 2 & 2.6 & 2 & 2,4 & $<0,05$ \\
\hline $\begin{array}{l}\text { Dagen inzer, } \\
\max 731\end{array}$ & & $682 \pm 65$ & & $693 \pm 75$ & & $<0,05$ \\
\hline $\begin{array}{l}\text { Medische } \\
\text { Consumptie }\end{array}$ & $\in / 731 \mathrm{dgn}$ & $767 \pm 15$ & 514 & $494 \pm 746$ & & 0,23 \\
\hline
\end{tabular}

De pwwarden (p) van dagen inzet en medische consumptie zijn berekend met behulp van de Mann-Whitney $U$ test, voor de overige p-waanden is de chi-kwadrattest gebruikt. De regullere opleiding voor manschappen vindt op drie centra net een verschillende locatie phats, waarbij een identiek programma wordt gehanteed. LMB stat woor een zwaardere en langere opleiding.

manschappen die een zwaardere (luchtmobiele) militaire opleiding hadden gevolgd dan in de uitgezonden fractie van de ABOHZIS-studiegroep.

Bij onderscheid van de uitgezonden militairen naar gevechtsfunctie dan wel gevechtsondersteunende functie bleek daartussen geen statistisch significant verschil in het aantal dagen inzetbaarheid te bestaan $(p=0,35)$.

Om de onderlinge effecten juister te kunnen beoordelen en om het mechanisme te vinden op grond waarvan de uitgezonden militairen uit de BMEKL-studiegroep beter presteerden, zijn vervolgens multiple lineaire regressie analyses gepleegd.

$\mathrm{Bij}$ de eerste is het antal dagen inzetbaarheid als athankelijke variabele gehanteerd tegenover het keuringssysteem, gevechts- of gevechtsondersteunende functie en de soort militaire opleiding als onafhankelijke variabelen. Hierbij bleek alleen de onafhankelijke variabele (soort) militaire opleiding statistisch significant te verschillen $(p<0,05)$. Uit een tweede regressie analyse met het keuringssysteem en de verschillende opleidingsplaatsen als afhankeljjke variabelen (tabel 34) bleek een associatie tussen zowel het keuringssysteem als de zwaarste opleiding voor manschappen en het aantal dagen inzetbaarheid. 


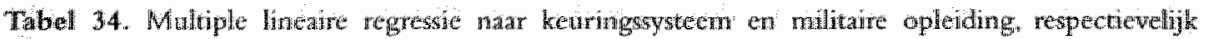

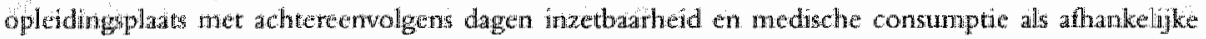
variabelon

\begin{tabular}{|c|c|c|c|c|}
\hline \multirow[t]{2}{*}{ Onafhankelijke warrabelen } & \multicolumn{4}{|c|}{ Afhankelijke variabele: dugen inzetbarheid } \\
\hline & Beta Coefficiènt & $\begin{array}{l}\text { Scandaard } \\
\text { fout }\end{array}$ & P-wwarde & $\mathrm{R}^{2}$ \\
\hline Keuringssystedin & -54 & 27 & $<0,05$ & \\
\hline \multicolumn{5}{|l|}{ (BMEKL V: ABOHZIS) } \\
\hline \multicolumn{5}{|l|}{ Type opleiding versus } \\
\hline \multicolumn{5}{|l|}{ Overige typen opleiding } \\
\hline Opleiding offecier & -90 & 97 & 0,23 & \\
\hline Opleiding onderofficier & -360 & 131 & 0,07 & \\
\hline Opleiding manschappen Noord & -24 & 39 & 0,55 & \\
\hline Opleiding marschappen Zuid & -37 & 28 & 0,50 & \\
\hline Opleiding manschappen Central & -44 & 42 & 0,31 & \\
\hline \multirow[t]{2}{*}{ Opleiding manschappen LMB } & -199 & 64 & $<0,01$ & \\
\hline & & & & 0,13 \\
\hline
\end{tabular}

Opleiding manschappen LMB (Luchtmobie) is langduriger en zwaarder, de opleidingen op de schoollbataljons Noord, Zuid en Centraal. Deze latste clric zijn qua programma identiek, maar verschillen clua locatie. Kaderleden worden opgeleid op aparte opleidingsinstituten. $\mathbb{R}^{2}$ stat voor de verklaarde variantie.

\subsubsection{Enquêtes}

Voor nadere analyse telden alleen de geheel ingevulde exemplaren van de vragenlijst mee. Tussen de uitgezonden militairen uit beide studiegroepen bestond geen verschil in respons inzake de tweede tot en met de vierde vragenlijst. De totale respons van de uitgezonden daalde tussen de tweede en de vierde vragenlijst van $69 \%$ naar $49 \%$.

De antwoorden op de vragen werden geclusterd. Vervolgens is behulp van lineaire regressic analyse de associatie onderzocht tussen de separate clusterscores en de uirkomstvariabele dagen inzetbaarheid. Bij deze analyse vertoonden de clusters Bewegingsapparaat (4) en Militaire punten (18) telkens een statistisch significante associatie met de uitkonstvariabele. Voor het cluster Algemene Gezondheid (3) werd deze associatie tweemaal vastgesteld. ( $3^{\mathrm{e}}$ en $4^{\mathrm{e}}$ vragenlijst); ten annzien van de clusters Bewegingsapparaat $\left(7 ; 2^{\mathrm{e}}\right.$ vragenlijst) en FIS-bewe-

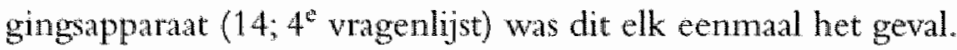

Vervolgens is multiple lineaire regressie analyse uitgevoerd met de hierboven vermelde clusters tezamen en het keuringssysteem als onafhankelijke variabelen, 
Tabel 35. De resultaten wan de multiple lineaire regressie analyse viet digen inzetbarthad als afharke]jike variabele en de chusters die op basis van lineare regressie analyse associatie wertoonden met inzetbaarheid, tezamen met het keuringsysteem als onthankelijke variabelen.

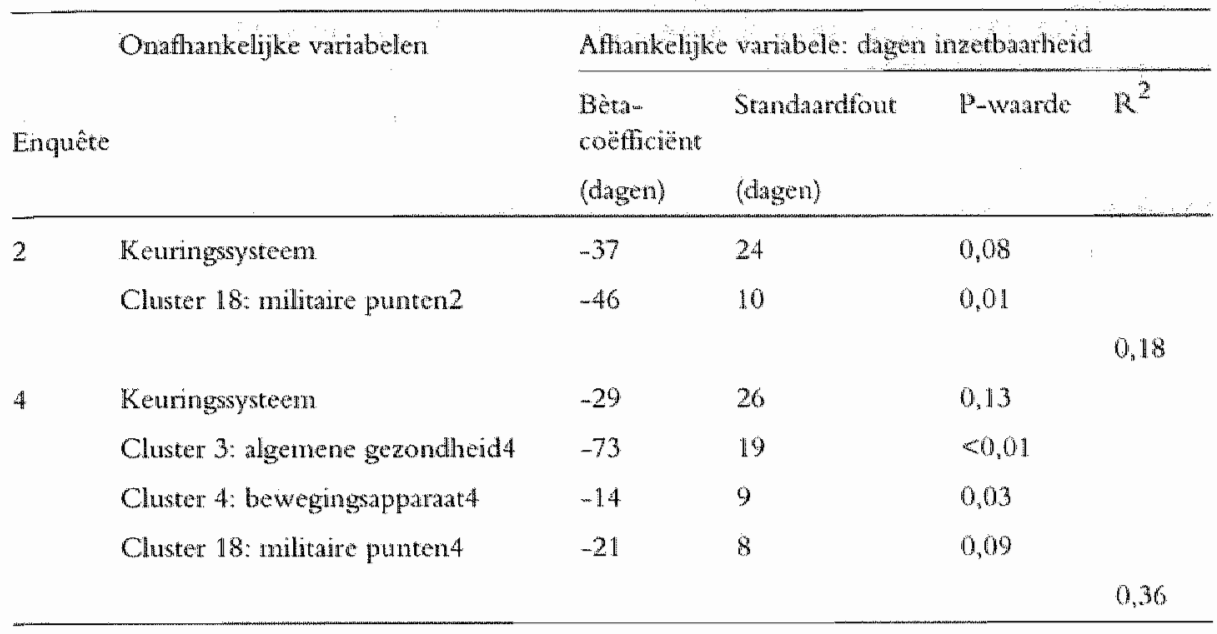

$R^{2}$ statat woor de verklaarde variantie.

met dagen inzetbaarheid als afhankelijke variabele. Uit deze analyse bleek (tabel 35) dat de clusters Algemene Gezondheid (3), Bewegingsapparaat (4) en Militaire beoordelingspunten (1.8) elk eenmaal een statistisch significante associatie vertoont met de inzetbaarheid. Bij deze analyse bleef de $\mathrm{p}$-waarde van het keuringssysteem $>0,05$, terwijl de verklaarde variantie in de tijd toenam.

\subsection{Beschouwing}

Uitgezonden militairen blijken statistisch significant meer dagen inzetbaar te zijn dan niet uitgezonden militairen, zonder dat dit tot een verschil in medische consumptie tussen beide groepen leidde.

Dit verschil in inzetbaarheid kan op meerdere gronden berusten. Zo zal iemand die zich heeft ziek gemeld niet mee op uitzending gaan. Er kan sprake zijn van selectie van de meest fitte en/of geschikte kandidaten. Gedurende cen uitzending is de sociale controle groter dan op de eigen kazerne, behoudens tijdens eventueel verlof kan niemand zich gedurende een uitzending ziek thuis melden. Andersom kan het niet worden uitgezonden tot teleurstelling, demotivatie en leegloop leiden gedurende de resterende periode van de arbeidsovereenkomst. Deze laatste verklaring wordt ondersteund door het feit dat er geen statistisch significant verschil bestaat tussen uitgezonden en niet uitgezonden militairen 
ten aanzien van de medische consumptie. Niet urtgezonden militaren vertonen een hoger verzuim zonder bijkomende meerkosten.

Dergelijke redenen kunnen het gevonden verschil in inzetbaarheid tussen de uitgezonden militairen uit beide studiegroepen niet verklaren. De uitgezonden fractic van de BMEKL-studiegroep is statistisch significant meer dagen inzetbaar geweest dan de uitgezonden fractie van de ABOHZIS-studiegroep. Dit sluit an bij wat in theorie in de inleiding werd verondersteld.

De fracties verschillen onderling verder qua opleidingsplaats en wat betreft de verfouding tussen het antal gevechtsfuncties en gevechtsondersteunende functies. Bij nadere analyse blijkt er een associatie te bestaan tussen het gesignaleerde verschil in inzetbaarheid en de zwaarste opleiding voor manschappen, maar dat verklaart het gevonden verschil in inzetbarheid niet.

Het ontbreken van een verschil in inzetbaarheid tussen gevechts- respectievelijk gevechtsondersteunende functies komt overeen met het verwachtingspatroon: het verschil tussen deze twee soorten functies komt pas tot uiting bij missies warbij de vrede moet worden afgedwongen of onder pure oorlogsomstandigheden. Daarvan was tijdens deze studie geen sprake.

Ondanks het ontbreken van dergelijke zware omstandigheden gedurende de tritzendingen in deze studie blijkt dat uitgezonden militairen die gekeurd zijn volgens het BMEKL-systeem beter presteren ten aanzien van gezondheidsklachten en het voldoen an specifieke militaire eisen dan de uitgezonden militairen die gekeurd zijn volgens het ABOHZIS-systeem. Aangezien het BMEKL-keuringssysteem, in tegenstelling tot het ABOHZIS-keuringssysteem, bestat uit het beoordelen of iemand aan die specifieke militaire functie-eisen voldoet, sluit deze bevinding aan bij de verwachting.

Kunnen deze bevindingen op een artefact berusten?

Door randomisatie is selectie-bias voorkomen. De fracties uitgezonden militairen zijn representatief voor wat geniddeld wordt uitgezonden wan alle militairen BBT: ze worden over de vier verschillende uit te zenden eenheden verdeeld. Wan deze eenheden worden gedurende de actieve dienstijd van de studiegroepen achtereenvolgens twee voor uitzending angewezen. Weliswar verschillen beide fracties ten anzien van de militaire opleidingsplats en in hun verhouding tussen gevechts- en gevechtsondersteunende functies, maar deze verschillen zijn niet van doorslaggevende invloed op de inzetbarheid. Bij de multiple lineaire regressie analyses blijkt immers dat de p-warde van het keuringssysteem niet tot boven de 0,05 stijgt. Een deel van de conclusies berust op de analyse van de an de $\mathrm{PBGO}$-vragenlijst toegevoegde clusters vragen. Die vragen zijn nimmer gevalideerd; ze zijn door de onderzoeker zelf ontwikkeld. Alle vragen zijn eenwoudig en helder geformuleerd, alle betreffen navraag naar 
een enkele handeling ("acht u uzelf in stat tot het 8 ur per dag dragen van een. helm?"). Bovendien is bij de analyse niet gebruik genaakt van de enkele vragen, maar van de clusters waartoe ze behoorden. Van de hiervoor gebruikte clusters is in elk geval angetoond dat de alfa boven de vereiste 0,50 ligt over alle drie voor dit onderzoek gebruikte vragenlujsten.

Samengevat komt uit dit onderzoek nar voren dat uitgezonden militairen, gekeurd volgens het functiegerichte BMEKL-systeem, een grotere inzetbaarheid vertoonden dan de uitgezonden militairen, gekeurd volgens het diagnosegerichte ABOHZIS-systeem. Het BEMKL-keuringsysteem voorspelt beter ten aanzien van het functioneren als militair in het algemeen en specifiek op basis wan uitzending, gezondheid en bewegingsapparat dan het ABOHZIS-systeem.

\section{Geraadpleegde literatuur}

1. Raad ] de, Peters JHM, Groor RP de et al: Modernisering van het keuringssysteem bij de Koninklijke Landmacht; keüngsprotocollen en functioneel beoordelen. TBV 2000; 8: 110115.

2. Dijk FJH van, Dormolen $M$ van, Kompier MAJ et al: Herwardering model belasting-belastbatheid. TSG, 1990;68: 3-10.

3. Kessel JGFM van: De consequenties van onjuist keuren. Ned Mil Geneesk T; $1984(37)$ : $176-228$.

4. Raad J. de, Peters JHM., Nijhuis FJM: De kwaliteit van een keuringssysteem. TBV 2000; $8: 105-109$.

5. Raad J de, Slootman EJH, Groot R.P de; Onderzoek naar de consistentie van het beoordelen van anstellingskeuringen woor de Kominklijke Landmacht. TBV 2002; 10:266-272.

6. Bouter LM, Dongen MCJM van: Epidemiologisch onderzoek, opzet en interpretatie. Bohn, Staflet en van Loghum. Houten, 1995.

7. Kort WLAM de: Personnel selection througln pre-employment medicals. Ansterdan, 1993.

8. Raad, J de, Redekop WK: A comparison between rwo systems for pre-cenployment medical assessment in the RNLA by a randomised-controlled study. Military Medicine 2004; $169(6): 437-443$.

9. Broersen JPJ, Weel ANH, Dijk FJH wan: Periodiek Bedrijfsgeneeskundig Onderzoek: middel en maatstaf. Amsterdam, 1989.

10. Putten DJ wan, Marcelissen $\mathrm{FGH}$, Winter CJ de: De vragenlijst voor PBCO $1-4$. Achtergronden voor het gebruik ervan. Het wijzigen wan antwoorden door bedrijfartsert. Methoden voor gebruik wan referentiegegevens. TSG 1988; 66: 115-120, 143-147.

I1. Putten DJ vam: De vragenlijst voor $\mathrm{PBGO}$, voorstellen tot wijziging van de vragenlijst. Leiden, NIPG/TNO, $198 \%$.

12. Raad, de, Redekop WK: Analysis of health factors as predictors for the functioning of military personnel. In februari 2004 door Military Medicine woor publicatie aanvaard. 
8 | Slotbeschouwing 


\subsection{Inlleiding}

In de vorige hoofdstukken is onderzoek beschreven naar het effect van aanstellingskeuringen bij militairen. Allereerst zijn niet-systematische en systematische waarnemingen weergegeven. Vanuit die waarnemingen is een theorie inzake de kwaliteit van keuringen geinduceerd. Mede op grond van die theorie is een nieuw keuringssysteem voor de KL ontwikkeld. Hierna is een hypothese gededuceerd, waarbij een verschil in kwaliteit tussen het nieuwe (BMEKL) en het oude (ABOHZIS) systeem werd verondersteld. Op basis van deze hypothese is een aantal onderzoeksvragen geformuleerd. Met behulp van deze vragen zijn vervolgens twee kwaliteitskenmerken van het meetinstrument keuring onderzocht.

Bouter en van Dongen [1] stellen dat de resultaten van één enkel onderzoek een theorie zelden kunnen maken of breken. Meestal is veel onderzoek nodig voordat een theorie voldoende in de empirie is verankerd. In feite, zo stellen zij [1], is een empirische spiral nodig om de werkelijkheid steeds nauwkeuriger te beschrijven. De toegevoegde waarde van het enkele onderzoek aan deze spiraal is afhankelijk van de hoeveelheid bewijslast, de interne en externe validiteit en de onvang van de onderzoekspopulatie [1].

In de hoofdstukken 2 tot en met 7 zijn al meer opmerkingen vermeld inzake de toegevoegde waarde van de betreffende onderzoeken. Thans kan echter de som der delen worden overzien. Daarbij valt niet uit te sluiten dat bij deze onderzoeken, apart of in onderlinge samenhang, nog kanttekeningen moeten worden geplaatst. Een nabeschouwing is noodzakelijk.

Na deze nabeschouwing kan, met inachtneming van eventuele kanttekeningen, de vraagstelling worden beantwoord. Met behulp van die antwoorden kan vervolgens de hypothese worden getoetst. Daarna kan worden nagegaan of en in hoeverre het onderzoek de theoric inzake keuringen heeft beïnloed. Als laatste kan worden nagegaan wat de betekenis van het onderzoek is geweest voor de empirische cyclus.

\subsection{Nabeschouwing van het verrichte onderzoek}

Hoofdstuk 2 valt als systematische waarneming buiten de eigenlijke vraagstelling van het onderzoek. Het onderzoek vormde echter de aanleiding tot het operationaliseren van de BMEKL en was op deze wijze van grote invloed op het verdere onderzoek. Bij dit onderzoek valt de volgende kanttekening te maken. De mate van overeenkomst - gemeten in kappa - ligt in dit onderzoek lager dan in het onderzoek zoals beschreven in hoofdstuk 4. Kan dit worden verklaard? Bij het ABOHZIS-systeem, zoals dat bij het PGO werd gehanteerd, 
was sprake van veel meer keuzemogelijkheden in de uitspraken (A1) of $\mathrm{H}_{2}, \mathrm{H}_{2}$ of H3 etc) dan bij de vaststelling van de aanstellingskeuring. Deze laatste vaststelling heeft een dichotoom karakter: men is geschikt of ongeschikt, ongeacht of van het nieuwe dan wel oude keuringssysteem sprake was. In hoofdstuk 3 is reeds opgemerkt dat de kappa onder meer afhankelijk is van het anatal beoordelingscategorieën (strata): hoe meer strata des te klleiner de kappa [1].

In hoofdstuk 3 is de reproduceerbaarheid van 30 pensioenkeuringen onderzocht volgens het BMEKL-systeem. De consistentie van het eindoordeel gemeten in $\mathrm{kappa}$ - is goed. Ook de meeste, in dit onderzoek meetbare beoordelingspunten komen er goed vanaf. De gebruikte hoeveelheid van 30 keuringsdossiers is echter een minimum voor onderzoeksdoeleinden. Het gewolg is dat maar een beperkt scala van medische bijzonderheden voorkomt, zodat niet elk beoordelingspunt kan worden getoetst. Voor een aantal wan die beoordelingspunten makt de gekozen hoeveelheid dossiers overigens niet uit. De constatering dat iemand beperkt is op sommige beoordelingspunten leidt al bij de aanstellingskeuring tot afwijzing (zoals een onvoldoende kleuronder scheidend vermogen). Dergelijke beperkingen komen bij de pensioenkeuring feitelijk nooit voor. Al met al moet worden erkend dat dit onderzoek maar een. beperkt inzicht geeft in de mate van overeenstemming bij de pensioenkeuring. Deze constatering doet echter geen afbreuk aan de uitspraken over die beoordelingspunten die wel te beoordelen vielen. Als latste moet worden vastgesteld dat in dit hoofdstuk wel inzicht is verkregen in cle inter-waanemers variatie, mar niet in de intra-warnemers variatic.

In hoofdstuk 4 wordt de betrouwbaarheid van beide keuringssystemen bij de aanstellingskeuring onderzocht. Hierbij worden vier verschillende overeenstemmingsmaten gebruikt. Als tekortkoming wit het tweede onderzoek geldt dat de oorspronkelijke beoordelar de samengestelde is van de drie werschillende oorspronkelijke uitslaggewend artsen. Daardoor valt intra-warnemers variatie niet te bepalen. Deze constatering doet echter geen afbreuk an de bevindingen op het gebied van de inter-warnemers variatie.

In de hoofdstukken 5, 6 en 7 wordt telkens gebruik gemaakt van gegevens afkomstig van dezelfde gerandomiseerde gecontroleerde studie. In die studie zijn twee onderzoeksgroepen geschikt verklaarde militairen (gekeurd wolgens één van beide keuringssystemen) twee jan gevolgd. Bij deze hoofdsukken kunnen de volgende kanttekeningen worden vermeld.

Uit de laatste hoofdstukken blijkt dat het nieuwe keuringssysteem cen betere voorspeller is ten aanzien van inzetbaarheid, maar dat het mechanisme waarop 
dit is gebaseerd niet kan worden achterhaald. Weliswar kan gewezen worden op bepaalde verschillen tussen beide keuringssystemen, die mogelijk tot een verklaring zouden kunnen leiden, maar wetenschappelijk gezien kan het mechanisme niet worden aangetoond.

Ondanks het voorkomen van selectiebias door randomisatie zou men kritiek kunnen hebben op de wijze van randomisatie (om de week van systeem wisselen). De indeling van gegadigden voor een aanstellingskeuring vindt echter volstrekt willekeurig plaats, waardoor een eventueel verschil tussen kandidaten die op de even en oneven weken worden gekeurd op toeval moet berusten. Het hanteren van een werkweek als termijn lijkt daarbij optimaal om dit onderzoek te verrichten. Het dagelijgs aselect aanbieden van op verschillende wijze te keuren kandidaten aan keurend artsen zou immers risico's opleveren: het gevaar verstrikt te raken in verschillende diagnostische classificatieschema's [1], expectation bias [1], motivatieproblemen bij de uitvoering en het bemoeilijken van de controle door derden op het gebruik van het juiste keuringssysteem. Als aanvullend bewijs dat deze vorm van randomisatie aanvaardbaar is wordt gewezen op de goede onderlinge verhouding qua onder meer leeftijd en geslacht in beide studiegroepen.

Het verzamelen van de gegevens voor het berekenen van de medische consumptie zou ook tot selectiebias kunnen leiden, met name ten aanzien van de "externe" consumptie (zorgafname buiten het eigen zorgsysteem warvoor declaraties bij de ziektekostenverzekeraar worden ingediend). Vrijwel in al deze gevallen wordt de betreffende declatatie niet door de verzekerde, maar door de zorgverlener ingediend bij de verzekeraar. Bovendien zou bij het niet declareren de militair de rekening zelf moeten betalen. Op basis van voornoemde argumenten wordt aangenomen dat de kans dat hierin selectiebias is opgetreden gering is.

Opgemerkt zou kunnen worden dat in de totstandkoming van de studiegroepen - die immers uit geschikt verklaarden bestonden - sprake kan zijn geweest van inter-doktersvariatie. De individuele interpretatie van de begrippen "geschikt" en "ongeschikt" zou tussen de tien betrokken keurend artsen tot (te grote) verschillen in de uiteindelijk geschikt verklaarde rekruten hebben kunnen leiden. Hierdoor zouden de uitkomsten kunnen zijn beinvloed. $\mathrm{Als}$ onderdeel van de introductie van het nieuwe keuringssysteem zijn onder meer al deze artsen tijdens een workshop voorbereid. Zoals ook in hoofdstuk 1 is beschreven, vormt het gebruik maken van keuringsprotocollen onderdeel van de methodiek, waardoor in theorie de eenduidigheid wordt bevorderd. Blijkens paragraaf 5.3 zit ook geen verschil in de onderlinge verhouding tussen geschikten ongeschiktverklaring $(p=0,27)$ tussen de artsen. Bovendien wordt, zoals in 
paragraaf 2 van hoofdstuk 4 al werd uiteengezet, de uitslag niet door de keurend artsen vastgesteld maar door drie vaste uitslaggevend senorbedrijfsartsen, van wie het oordeel volgens datzelfde hoofdstuk 4 in goede tot voortreffelijke mate reproduceerbaar bleek te zijn. Op grond van de hierboven weergegeven redenatie wordt aangenomen dat een eventuele inter-doktersvariatie de resultaten niet in ernstige mate heeft beïnvloed.

De onderzoeksgroep had aanzienlijk uitgebreid kunnen worden indien gekozen was om ook die militairen te volgen, die al in de militaire opleiding (AMO) de dienst alweer verlieten. Het meenemen van de reeds tijdens de AMO vertrekkende militairen had de onderzoeksgroep weliswaar optisch. aanmerkelijk groter gemaakt, maar door de uiterst korte periode waarin zij effectief bij de KL aanwezig waren (niet werkzaam, maar slechts in opleiding), zou dit weinig waarde ann het onderzoek hebben toegevoegd.

Ook bij de clustering kunnen kanttekeningen worden gemaakt. Bij het stellen van een enkele vraag naar een bepaald onderwerp kan de foutieve interpretatie van de respondent een verstorende rol spelen. Dit effect kan worden bestreden door meer vragen over hetzelfde onderwerp te stellen: clustering - reden waarom clustering voor het onderzoek uit de hoofdstukken 6 en 7 heeft plaatsgevonden. Voorwaarde voor clustering is dat er voldoende correlatie tussen die vragen bestaat. Clustering heeft volgens Swanborn [2] en Meerling [3] zowel voor-als nadelen. De voordelen zijn onder meer dat de clusterscore betrouwbaarder is dan de score op een enkele vraag en dat de informatie kort en overzichtelijk kan worden gepresenteerd. Als nadelen worden onder meer aangehaald dat men zo signalen kan missen en dat de informatie op een hoger abstractieniveau komt te liggen. Het abstractieniveau vormde voor deze clusters geen nadelig effect. Voor zover ze tot de oorspronkelijke PAGO-vragenijst behoorden, waren ze all gedefinieerd en werden ze door verschillende onderzoekers als zodanig gebruikt $[4,5]$. Dat mogelijk signalen, afkomstig van een enkele vraag, kunnen zijn gemist, kan nadelig zijn, maar doet aan de conclusies inzake de clusters geen afbreuk.

Diezelfde onderzoekers $[4,5]$ wijzen bovendien op het feit dat de reactie op de PAGO-clusters altijd assymmetrisch is: de meerderheid van de werknemers rapporteert weinig tot geen klachten, sommigen daarentegen rapporteren juist veel klachten op vragen uit een cluster. Dit zou volgens deze auteurs de lijst vooral geschikt maken voor het opsporen van knelpunten. Aangezien het de intentie was om verschillen te zoeken behoeft ook dit niet als verstorend voor het onderzoek te worden beschouwd. 
Var de hierboven vermelde kanttekeningen is een aantal van belang voor het beantwoorden van de vraagstelling in de volgende paragraaf. Deze worden hieronder samengevat.

In algemene zin valt het onderzoek uiteen in twee delen in het eerste deel wordt onderzoek verricht naar de mate van overeenstemming (werkt het systeem kwalitatief?), in het tweede deel wordt onderzoek verricht naar de prognostische waarde van beide keuringssystemen.

Wat het eerste gedeelte betreft, is het onderzoek beperkt gebleven tot het beoordelen van de inter-waarnemers variatie. Dit kan weliswaar als een tekortkoming worden opgevat, maar doet geen afbreuk an de conclusies inzake de gevonden inter-waarnemers variatie.

Het tweede gedeelte is beperkt gebleven tot de in dienst tredende en niet al tijdens de opleiding weer vertrekkende keurlingen. Daarmee valt geen uitspraak te doen inzake de validiteit. Er is weinig reden om te twijfelen aan de uitkomsten van het rekenmodel zoals De Kort [6] dat in 1997 publiceerde. Daarom kan niet worden uitgesloten dat ook in deze studie meer fout-positieven tegelijk met een enkele risicodrager worden geweerd. Daaraan kan ter verdediging van het keuringssysteem worden toegevoegd dat de nauwkeurige definiëring van de meeste Basismedische Eisen (Tabel 1, hoofdstuk 1) in elk geval theoretisch de variatie in de besluitvorming zal beperken.

Tevens blijkt uit de hoofdstukken 5, 6 en 7 dat het nieuwe BMEKL-keuringssysteem een betere voorspeller is ten aanzien van inzetbaarheid dan het oude ABOZIS-systeem. Het lijkt aannemelijk dat het nieuwe keuringssysteem, gebaseerd op de feitelijke taakstelling (met inbegrip van operationele inzet), onder operationele omstandigheden ook beter voorspelt, omdat het nu juist voor die omstandigheden is ontworpen.

Maar het mechanisme warop dit is gebaseerd kan wetenschappelijk niet worden aangetoond.

Met inaclatneming van deze bemerkingen kan thans de vraagstelling worden beantwoord.

\subsection{Beantwoording van de vraagstelling}

In paragraaf 1.5.7. zijn voor het onderzoek naar de kwaliteit van het BMEKL-keuringssysteem ten opzichte van het ABOHZIS-keuringssysteem vijf vragen gesteld. Nadat in hoofdstuk 2 een systematische waarneming is beschreven, waaruit de lage reproduceerbaarheid van het oude ABOHZIS-keuringssysteem naar voren kwam, hebben die vijf vragen als onderzoeksvraag deel uitgemaakt van de hoofdstukken 3 tot en met 7 . In de vorige paragraaf is andacht besteed aan kanttekeningen die bij deze hoofd- 
stukken kunnen worden geplaatst. Hierdoor wordt het mogelijk deze vijf vragen thans te beantwoorden.

De eerste onderzoeksvraag was: "Voldoet de reproduceerbaarheid van het nieuwe keuringssysteem bij de pensioenkeuring aan de normering die gebruikelijk is voor screeningstesten?"

Volgens Bouter en van Dongen [1] suggereren gepubliceerde onderzoeksgegevens dat een kappa tussen de 0,40 en 0,75 voor diagnostische testen in de klinische diagnostiek gebruikelijk is. In hoofdstuk 3 wordt de beoordeling volgens het BMEKL-systeem van 30 aselect gekozen dossiers van recente pensioenketiringen door twee seniorbedriffsartsen onderzocht. Dit levert ten aanzien van thet definitieve geschiktheidoordeel een Kappa op van 0,74 (0.48-0.98) en een PD van $13,3 \%$.

Op grond hiervan kan de gestelde vraag bevestigend worden beantwoord voor wat betreft de inter-waarnemers variatie.

De tweede onderzoeksvraag was: "Hoe verhoudt zich de mate van overeenstemming tussen beide keuringssystemen bij de aanstellingskeuring?"

In hoofdstuk 4 wordt de reproduceerbaarheid van het geschiktheidoordeel bij de aanstellingskeuring van beide keuringssystemen vergeleken. Er wordt gebruik gemaakt van 227 keuringsdossiers van de aanstellingskeuring; bij het onderzoek zijn op drie dit terrein ervaren seniorbedrijfsartsen betrokken. Elke vergelijking levert een zeer hoge mate van onderlinge overeenstemming op, ongeacht welk keuringssysteem wordt beoordeeld.

Op grond van dit onderzoek kan worden geconstateerd dat ten aanzien van de medische aanstellingskeuring beide keuringssystemen, voor wat betreft de inter-waarnemers variatie, een even hoge mate van overeenstemming vertonen.

De derde onderzoeksvraag was: "Is er een verschil in prognostische waarde tussen beide keuringssystemen ten aanzien van de geschikt verklaarde militairen BBT op het gebied van de dagen inzetbaarheid en/of de genoten medische consumptie?"

Uit een gerandomiseerde, gecontroleerde studie, beschreven in hoofdstuk 5 blijkt dat militairen, gekeurd volgens het nieuwe keuringssysteem (BMEKL) gedurende een periode van twee jaar na de opleiding statistisch significant meer dagen (648 versus 612) inzetbaar waren en minder medisch consumeerden ( $€$ 396 versus $€ 746$ ) dan millitairen die terzelfder tijd volgens het oude keuringsys-teem (ABOHZIS) waren gekeurd. Daarmee is de inzetbarheid van $84 \%$ tot $89 \%$ toegenomen. Niet alleen de prognostische waarde, maar ook de construck validiteit is toegenomen. 
Het antwoord op de derde vraag is derhalve dat er een verschil in prognostische warde tussen beide keuringssystemen bestaat, waarbij keuring volgens het nieuwe BMEKL-systeem zowel meer dagen inzetbaarheid als lagere medische consumptie oplevert dan keuring volgens het ABOHZIS-systeem.

De vierde onderzoeksvraag was: "Indien een verschil in prognostische waarde tussen beide keuringssystemen wordt gevonden, kan het mechanisme daarvan worden verklaard door analyse wan de determinanten persoonskenmerken, de eigen beleving van gezondheid, inzetbaarheid en operationele inzet?"

In hoofdstuk 6 wordt een analyse verricht van gegevens, afkomstig van dezelfde studie als in hoofdstuk 5 , met inbegrip van de resultaten van een halfjaarlijks afgenomen vragenlijst. Uit die analyse blijkt dat een aantal factoren wordt gevonden die van invloed zijn op de inzetbaarheid en de medisch consumptie. De betere prestatie van het BMEKL-keuringssysteem lijkt deels te kunnen worden toegeschreven aan het vermogen om op taakspecifieke eisen te beoordelen. Maar het primaire mechanisme waarop dit is gebaseerd, blijft verborgen. Het antwoord op de vraag hierboven is derhalve dat er weliswaar vermoedens zijn dat het BMEKL-keuringssysteem beter voorspelt omdat het ook beter is gericht op het functioneren als militair, maar dat dit niet kan worden aangetoond.

De vijfde en laatste onderzoeksvraag was: "Bestaat er ook een verschil in prognostische warde tussen beide keuringssystemen ten aanzien van uitsluitend de uitgezonden militairen en zo ja, kan dat worden verklaard door analyse van de determinanten persoonskenmerken, het beleven van de eigen gezondheid, de eigen beleving van gezondheid en inzetbaarheid?"

In hoofdstuk 7 zijn de uitgezonden militairen uit beide studiegroepen aan nadere analyse onderworpen.

De aitgezonden millitairen, gekeurd volgens het BMEKL-systeem, zijn meer dagen inzetbaar geweest, vertonen minder gezondheidsklachten en achten zichzelf meer in stat tot het voldoen an specifieke militaire eisen dan de uitgezonden militairen die gekeurd zijn volgens het ABOHZIS-systeem.

Het antwoord op de gestelde vraag is dat inderdaad een verschil in prognostische waarde wordt gevonden in het voordeel van het BMEKL-keuringssysteem; dit verschil lijkt te zijn gebaseerd op het beleven van de eigen gezondheid en de mate waarin men zich bekwaam acht tot het verrichten van de vereiste taken. 


\subsection{Toetsing van de hypothese}

In hoofdstuk 1 is gesteld dat het nieuwe BMEKL-keuringssysteem, anders dan het oude ABOHZIS-keuringssysteem, in hoofdzaak an het gestelde in zowel de WMK als de ARA voldoet. Daaruit werd geconcludeerd dat dit hypothetisch zou moeten betekenen dat de kwaliteit van het BMEKL-keuringssysteem beter zou moeten zijn dan die van het ABOHZIS-systeem. Op grond van deze hypothese zijn de verschillende onderzoeksvragen getormuleerd. Op deze onderzoeksvragen is in de vorige paragraaf antwoord gegeven.

Uit de beantwoording van de vragen kan worden opgemaakt dat de reproduceerbaarheid van het nieuwe keuringssysteem in alle onderzochte gevallen volstaat. Echter, anders dan in tabel 6 in hoofdstuk 1 het gevall leek te zijn, blijkt uit hoofdstuk 4 de reproduceerbaarheid van het ABOHZIS-systeem even goed te volstaan wanneer het om de aanstellingskeuring gat. De vermoedelijke verklaring daarvoor is hierboven in paragraaf 8.2.uiteengezet. Het woord "situationeel" lijkt derhalve op de reproduceerbaarheid van het ABOHZIS-systeem van toepassing. Omdat keuringen zoals vermelde in hoofdstuk 2 echter niet meer voorkomen en dit onderzoek de aanstellingskeuring betrof, kan niet worden gesteld dat de kwaliteit van het nieuwe systeem inzake de reproduceerbaarheid beter is dan het oude.

Anders is dit wat de prognostische warde bij geschikt verklaarde militairen betreft. Uit drie achtereenvolgende onderzoeken blijkt dat deze prognostische waarde voor het BMEKL-systeem hoger ligt, met name onder operationele en andere zware omstandigheden. Weliswaar kan het mechanisme waarop dit is gebaseerd niet worden achterhaald, maar de constatering uit de laatste drie onderzoeken valt daarmee niet weg. Er zijn zelfs aanwijzingen, op grond van de vragenlijst, dat het verschil te herleiden zou zijn naar de eigen beleving van gezondheid en taakbekwamheid. Het feit dat de eisen van het nieuwe BMEKL-keuringssysteem waren afgeleid van de feitelijke takstelling - anders dan het ABOHZIS-systeem - deed vooraf vermoeden dat het BMEKL-systeem beter zou functioneren. $\mathrm{Nu}$ dit laatste, althans wat de prognostische waarde bij geschikt verklaarde militairen betreft, ook is angetoond, wordt dit opgevat als een bevestiging van het feit dat de hypothese juist is geweest.

In tabel 36 wordt, analoog aan tabel 6 uit hoofdstuk 1, een overzicht gegeven van de stand van zaken voor beide keuringssystemen ten opzichte van de kwaliteitscriteria, zoals de onderzoeker deze zelf na afloop van het onderzoek beschouwt. 
Tabel 36. De stand yan zaken met betrekking tot de kwaliteitskenmerken van de BMKEL.-keuring en ABOHZIS-heuring tha aloop wan het werrichte onderzoek.

\begin{tabular}{|c|c|c|c|}
\hline $\begin{array}{l}\text { Kwaliteisikenmerk } \\
\text { Keuning }\end{array}$ & ABOHZIS & BMEKL & Toelichting \\
\hline Relevantie: & \multicolumn{2}{|c|}{ Vernoedelijk gelijkwaardig } & $\begin{array}{l}\text { Getheten kenmerk moet betekenis hebben } \\
\text { gelet op het met de test beoogde doel }\end{array}$ \\
\hline Toepasbartheid & \multicolumn{2}{|c|}{ Vermoedelijk gelijkwardig } & $\begin{array}{l}\text { Toegesneden op situatie, proportioned, } \\
\text { subsidiair, woor alle partijen acceptabel } \\
\text { (umplementatie) }\end{array}$ \\
\hline Efficiente & \multicolumn{2}{|c|}{ Vermoedelijk gelijkwardig } & $\begin{array}{l}\text { Minimalisering van inspamingen en } \\
\text { uitgaven }\end{array}$ \\
\hline Validiteit & $\begin{array}{l}\text { Gedeeltelijk } \\
\text { bekend; } \\
\text { lager }\end{array}$ & $\begin{array}{l}\text { Gedeelrelijik } \\
\text { bekend; } \\
\text { hoger }\end{array}$ & $\begin{array}{l}\text { Operationalisatie, uitwoering, te meter } \\
\text { concept: sensitiviteit/specificiteit, } \\
\text { diagnostische waarde, gouden standward }\end{array}$ \\
\hline \multirow[t]{2}{*}{ Reproduceserbarheid } & Situationeel & Altijd hoog & Inter-waarnemers variatie \\
\hline & \multicolumn{2}{|c|}{$\begin{array}{l}\text { Hoog bij } \\
\text { aanstellingskewringen }\end{array}$} & $\begin{array}{l}\text { (Intra-waarnemers variatie nict } \\
\text { beoordeeld) }\end{array}$ \\
\hline
\end{tabular}

Met "gedeeltelijk bekend" achter "validiteit" wordr de uitkomst van bet onderzock naar de woorspellende waarde uit de hoofdstukken $5,6 \mathrm{en} 7$ aangeduid, warin BMEKL gekeurde militanen een hogere inzetbasheid vertoonden dan de ABOHZIS-gekeurden. Met "situationeel" wordt het verwehil in reproduceerbatheid wan het ABOHZIS-ketringssysteem uit de howdstukken 2 (Periodick Geneeskundig Onderzoek) en 4 (aanstellingsketringen) angeduid.

\subsection{Aanpassing van de theorie?}

De theorie is dat de kwaliteit van aanstellingskeuringen als meetinstrument te wensen over laat. Aan de hand van de hypothese en de operationalisatie van de onderzoeksvragen uit hoofdstuk 1 heeft dat geleid tot de stelling dat de kwaliteit van anstellingkeuringen voor militairen dusdanig gering is, dat aanstellingskeuringen geen invloed op de inzetbaarheid van het personeel uitoefenen. In deze studie is angetoond dat anstellingskeuringen wel degelijk invloed op de inzetbarheid van het personeel uitoefenen. Voorts is hieruit gebleken dat het keturingssysteem, dat is afgeleid van de feitelijke taakstelling van de (althans militaire) werknemer en dat op hoofdlijnen voldoet aan de eisen van WMK en ARA, een hogere kwaliteit oplevert dan het keuringssysteem dat niet aan de vermelde twee voorwaarden (afgeleid van de tak, voldoen aan WMK en ARA) voldoet. Anders dan bij voorgaande onderzoeken zoals die van De Kort [7] is in deze studie voor een lange onderzoeksperiode gekozen.

Moet de theorie nu worden aangepast? Voor het beantwoorden van deze vraag worden hieronder de volgende argumenten gehanteerd. 
Weliswatr is angetoond dat anstellingkearingen unvloed op de intetbathed vam het personeel utoefenen, maar het mechanisme warop die invloed berwst kan niet worden aangetoond. Hooguit kan het vermoeden worden gevit dat dit mechanisme niet op fysieke gronden, maar op mentale gronden berust, zoals in het onderzoek van Carbone [8].

Het percentage afgekeurden ligt in deze studie voor beide keuringsystenen ( 13 $-16 \%$ exclusief uitval door fysieke selectie) hoger dan de percentages die in het onderzoek van De Kort [7] worden vermeld. Het argument van De Kort [7] dat een keuring weinig toevoegt aan het wervingsproces op grond wan een laag percentage afgekeurden, is in deze studie derlalve niet van toepassing.

De medische bijzonderheden blijken bij geschikt verklaarden niet maatgevend voor de inzetbartheid of de medische consumptie, evenmin als welk ander persoonskenmerk. Net als in het proefschrift van De Kort [7] ontbreekt in deze studie de relatie tussen medische bijzonderheden en de oorzak van de uitval op het werk. Tijdens de aanstellingskeuring wordt veel onderzocht dat geen voorspellende waarde voor geschikt verklaarden blijkt te bezitten. Daarmee is overigens nog niet aangetoond dat medische bijzonderheden ten opzichte van ongeschikt verklaarden geen waarde hebben. Maatgevend bij geschikt verklarden lijkt immers hoezeer men zichzelf tot het verrichten van taakspecifieke militaire eisen in staat acht. Dit kan inhouden dat instrumenten om zelfoverschatting te bewaken op hun plaats zouden kunnen zijn, makr dat is in deze studie geen onderwerp van onderzoek geweest.

Voor deze studie zijn andere effectvariabelen gebruikt dan die welke De Kort [7] hanteende. Voor militairen van de KL is bijvoorbeeld met name inzetbarr heid een zeer aanvaardbare effectvariabele, maar daarmee is nog niet angetoond dat deze effectwariabele ook voor de overige in ons land voorkomende beroepen toegepast kan worden.

De bijzondere taakstelling van de militair speelt een rol in dit onderzoek. De militair wordt niet voor een bepaalde, welomschreven functie gekeurd, mar voor het kunnen uitoefenen van een breed scala aan opdrachten, waaraan de nodige uiteenlopende risico's zijn verbonden - multifunctioneel. Juist die bredé taakstelling rechtwaardigt een keuring met een breed spectrum, samen met administratieve, psychologische en fysieke selectie. De meeste beroepen in ons land zijn aanmerkelijk minder pluriform van aard, zeker wat betreft de eran verbonden risico's. Als bij dergelijke beroepen al een anstellingskeuring mag platsvinden, dan kan daarbij vermoedelijk de door De Kort [7] gekozen effectvariabele zeer adequaat worden toegepast, terwijl de in deze studie gekozen effectvariabelen wellicht minder invloed zullen hebben. Al net al lijken de resultaten van dit onderzoek niet eenvoudig naar andere werksituaties te extrapoleren. 
De weergegeven argumenten leiden tot de volgende afweging. Dat in deze studie de keuring invloed uitoefent kan op meerdere factoren berusten, zoals de gebruikte effectvariabelen, het feit dat is voldaan an wettelije normen, wastoor deze keuring een afspiegeling vormt van de werkelijke te werwachten belasting en de lange onderzoeksperiode. Daarnaast kan niet worden uitgesloten dat het resultaat uit deze studie (te) sterk samenlangt met de specifieke werkzaamheden van de onderzoekspopulatie.

Ook kan niet concretet worden vastgesteld op grond warvan de keuring invloed uitoefent. Die invloed ligt in elk geval niet an een associatie tussen keuringsbevindingen en redenen voor uitval. Sterker, men kan zich afvragen of de mogellike reden (zoals motivatie) wel in een medische keuring thuishoort. Vanuit deze redenatie kunnen vier mogelijke verklaringen worden onderscheiden, of wellicht een combinatie daarvan:

- De voor deze studie gekozen variabelen wormen een concrete aanvulling voor onderzoek naar het effect van keuringen, waarmee bij toekomstig onderzoek rekening moet worden gehouden.

- Keuringen die voldoen aan de eisen, gesteld in WMK en ARA, hebben effect op werknemers, dit in tegenstelling tot keuringen die daaraan niet voldoen.

- Het resultat van deze studie kan uitsluitend worden bereikt bij een onderzoek naar een populatie die zwar en gevarieerd werk verricht.

- Het effect op werknemers uit deze studie is gebaseerd op een niet-medisch mechanisme.

Het bovenstaande kan worden opgevat als vier hypothesen ter mogelijke verklaring van de gevonden variaties in uitslagen. Het valt echter buiten het bestek van dit onderzoek om deze hypothesen te toetsen. Uitsluitend wanneer één van de eerste twee verklaringen juist zou zijn (of beide), zou de theorie worden beinvloed. Over de voor- en nadelen van de in de eerste verklaring vermelde effectvariabelen is zowel hierboven als in hoofdstuk 1 voldoende opgemerkt. In het woordeel van de tweede verklaring kan worden gesteld dat de invoering van de WMK ongetwijeld ook tot doel had dat de toegestane keuringen effect zouden hebben. De derde verklaring beinvloedt de theorie niet of nauwelijks; de laatste verklaring ondersteunt de theersende theorie. Alle verklaringen zijn het gevolg van éen studie. Zelfs indien één van de eerste twee verklaringen juist zou zijn, dan nog blijft van toepassing wat in de inlleiding is gesteld: de resultaten van éen enkel onderzoek kunnen een theorie zelden maken of breken. Meestal is veel onderzoek nodig voordat een theorie voldoende in de empirie is verankerd [1]. 
Er is geen aanleiding om op grond wan deze bevindingen de theorie te wijzigen. Wel kunnen deze resultaten worden beschouwd als een ansporing tot verder onderzoek. In de zin van de empirische spiral zal nog meer onderzoek moeten worden verricht vooraleer revisie van de theorie moet worden overwogen.

\subsection{Over keuringen: de betekenis van dit onderzoek voor de empirische spiraal}

In tabel 36 is de stand van zaken van het BMEKL-systeem ten opzichte van de vijf kwaliteitskenmerken aan het einde van deze studie weergegeven, naar de visie van de onderzoeker. In de vorige paragraf zijn verklaringen aangedragen voor de bevindingen uit dit onderzoek. Welke onderwerpen voor verder onderzoek levert dat tezamen op? Zonder de pretentie uitputtend alle mogelijkheden weer te geven, volgt hieronder een opsomming op hoofdlijnen op grond van de bevindingen uit deze studie.

Wat de relevantie betreft $k$ an de werkelijke betekenis van het gemeten kenmerk pas worden vastgesteld indien de validiteit of de gehele voorspellende waarde van het systeem wordt vastgesteld. Dan pas wordt immers bekend hoe relevant de gemeten kenmerken feitelijk zijn.

Inzake de toepasbaarheid en efficiëntie is al opgemerkt dat bij de keuring veel kenmerken worden onderzocht die in deze studie geen prognostische aarde bleken te bezitten. Ook bleek het aantal verschillende categorieèn medische bijzonderheden die een rol spelen bij de aanstellingskeuring beperkt te zijn. Deze constateringen nodigen uit tot het verrichten van een studie naar de mogelijkheden om het aantal gehanteede keuringsinstrumenten te reduceren. Deze bemerking sluit aan op de kanttekeningen die in paragraaf 1.4.2. bij toetsing van het BMEKL-systeem aan de ARA werden gemaakt en die hier tevens als aanbevelingen voor nader onderzoek kumnen worden weergegeven: er moet nog nader onderzoek worden verricht naar de validiteit, proportionaliteit en/of relevantie van bepaalde ter keuring gehanteerde meetinstrumenten, evenals naar het uiteindelijke effect van het Convenant Fysieke Belasting tussen de Ministeries van SZW en Defensie).

Inzake de reproduceerbaarheid kan nader onderzoek naar de intra-waarnemers variatie worden aanbevolen.

Of het te meten concept valide is, is slechts gedeeltelijk aangetoond. Weliswar is er nog steeds geen gouden standaard, maar nast de in paragraaf 1.4.1. aannemelijk gemaakte "face validity" [1] en "expert validity" [1] is nu ook de prognostische waarde voor geschikt verklarden aangetoond. Hierdoor kan dit onderzoek de basis vormen voor een studie naar de prognostische warde, waarin tevens de afgekeurden worden gevolgd. 
Door in een dergelijke studie zowel de effectvariabele van De Kort [7] te gebruiken als de effectvariabelen uit deze studie, zouden meer associaties tegelijk kunnen worden onderzocht. In de eerste plaats kan het belang van alle effectvariabelen worden herbeoordeeld, waarbij ook de onderlinge verhouding qua relevantie kan worden vastgesteld (welke associatie is het sterkst?). Zowel herbevestiging van de associaties uit dit onderzoek, als het mogelijk vinden van een associatie tussen ketringsbevindingen en uitval wegens arbeidsongeschiktheid kunnen voorts worden beschouwd als bewijs dat functiegericht keuren conform de in WMK en ARA weergegeven eisen wel invloed op de theorie heeft. Gegeven de resultaten uit de in dit proefschrift weergegeven studie zou hiervoor mogelijk kunnen worden volstaan met het hanteren van een vragenlijst. In deze lijst moeten - naast de in deze studie gehanteerde - ook de onderwerpen verzuim, arbeidsongeschiktheid en motivatie worden opgenomen. Een knelpunt in zulk onderzoek kan worden gevormd door de (te lage) respons bij niet actief dienenden, zoals ook in deze studie het geval was.

Om het mechanisme achter het effect te achterhalen is ook nader onderzoek geïndiceerd. Bij dat onderzoek kan bij het determineren van te meten variabelen rekening worden gehouden met de in Figuur 17 uit hoofdstuk 6 weergegeven mogelijke factoren (zelfinzicht, psychische belastbaarheid, opleiding, motivatie, blessures, gezondheid en operationele inzet). Van de keurend arts kan worden gevraagd om bij bepaalde factoren, zoals motivatie of algemene gezondheid, een gradatie aan te geven bij de kandidaten, bijwoorbeeld door middel van een schaalverdeling.

Qok zou kunnen worden beoordeeld of de in deze studie gevonden onderzoeksresultaten afhankelijk zijn van de aard van de werkzaamheden. Daarvoor zou een soortgelijke studie als in de vorige alinea's is weergegeven moeten worden herhaald bij een niet-militaire werknemerspopulatie, waarvoor eveneens een aanstellingskeuring is geïndiceerd.

Kortom, over keuringen kan ook in de toekomst nog voldoende onderzoek worden gepubliceerd.

\section{Geraadpleegde literatuur}

1. Bouter LM, Dongen MCJM van: Epidemiologisch onderzoek, opzet en interpretatie. Bohn, Stafletu en van Loghum. Houten, 1995.

2. Swanborn $\mathbb{P} G$ :Methoden van social-wetenschappelijk onderzoek. Meppel, Boom, 1987.

3. Meerling: Methoden en technieken van psychologisch onderzoek. Meppel, Boom, 1989. 
4. Putten DJ van, Marcelissen FGH, Whater CJ de: De vragenlijst noor PBCO 1-4. Achtergronden voor het gebruik erwan. Het wajzigen van antwoorden door bedryfsittsen. Methoden voor gebruik van referentiegegevens. TSG 1988; 66: 115-120,143-147.

5. Vrijlrof BJ, Broersen JPI: De structuur van de vragenlijst voor periodiek bedrijsgezondheidkundig onderzoek (PBGO). Tijdschrift voor toegepaste arbowetensetap $1993 ; 6: 14-17$.

6. Kort WLAM de, Dijk FJH van: Preventive effectiveness of pre-cmploymert medical assessments. Occupational Environmental Medicine 1997; 54: 1-6.

7. Kort WLAM de : Personnel selection through pre-employment medicals. Amsterdim, 1993.

8. Carbone $\mathrm{EG}_{\text {" }}$ Cigrang $\ \mathrm{~A}$, Todd SL et al: Predicting outcome of military basic training for individuals referred for psychological evaluation. J Pers Assess 1999;72(2):256-265. 
166 
Bijlage:

Verklaring van begrippen en afkortingen 
ABOHZIS

Classificatie

AMAR

AMO

ARA

Arbo-dienst $\mathrm{KL}$

BBT

BLS

BMEKL

BOT

Brigade

CTG

Dienstongeschikt
Selectiesysteem, waarbij ziekten en gebreken worden verdeeld naar: Algemene fysieke toestand, Bovenste extremiteiten, Onderste extremiteiten, Horen, Zien, Intelligentie en Stabiliteit.

Algemeen Militair Ambtenaren Reglement, warin de rechtspositie is omschreven.

Algemene Militaire Opleiding, die elke militair initieel ontvangt.

Algemene Richtlijn Aanstellingskeuringen.

Interne Arbo-dienst ten behoeve van zowel de Koninklijke Landmacht als de Koninklijke Marechatussee.

Beroepsmilitair Bepaalde Tijd, militair ambtenaar met een contractuele verbintenis voor een beperkte tijd, vaak $2 \frac{1}{2}$ jaar.

De Bevelhebber der Landstrijdkrachten, de werkgever (tot september 2005).

Basismedische Eisen KL, keuringssysteem gebaseerd op het model belasting- belastbaarheid.

Beroepsmilitair Onbepaalde Tijd, militair ambtenaar met een contractuele verbintenis tot aan het functioneel leeftijdsontslag (thans 55 jaar of ouder).

Resultaat Verantwoordelijke Eenheid (RVE), bestaande uit meerdere bataljons. Grootste eenheid die op grond van de Defensienota buiten de eigen landsgrenzen operationeel kan worden ingezet voor peace-keeping tot en met peace-enforcing missies.

College Tarieven in de Gezondheidszorg.

Medisch ongeschiktheidoordeel op grond van verschillende artikelen uit het AMAR, zoals door middel van de pensioenkeuring of de aanstellingskeuring IKS. 
DP\&O

Expert-validity

Face-validity

FIS

IBDKL

IGO

IKS

Keurend arts

$\mathrm{KFOR}$

KL

KLu
Directie Personed \& Organistue KL; contrale personeelsdienst, onderdeel van de "Hagse Stanen". Sinds. juni 2004 Personeelscommando geheten.

Validiteit, gebaseerd op het oordeel van deskundigen (bijvoorbeeld audiometrie-criteria laten vaststellen door $\mathrm{KNO}$-artsen).

Validiteit "op het oog" (bjuoorbeeld "timmermansoog'").

Functie Informatie Systeem. Met behulp van het belastbaarheidpatroon van 28 beoordelingspunten is in de vorige eeuw voor de Nederlandse matktsector de belasting van bestaande arbeid in kaart is gebracht, waarna voor elke functie of beroep het specifieke patroon in een database is opgenomen. Op deze wijze konden bij de WAO-keuring geconstateende beperkingen worden gekoppeld aan functies die, met inachtneming van die beperkingen, nog konden worden verricht door de betrokken werknemer. Bij veel van. deze beoordelingspunten kon gedifferentieerd worden tussen meerdere prestatieniveaus.

Individuele Begeleidingsdienst KL, IBDKL. Speciale eenheid voor de reintegratie van langdurig verminderd inzetbare militairen.

Incidenteel Geneeskundig Onderzoek. Voor KL en KMar uitgevoerd door de VGDKL op grond van AMAR Artikel 99, meestal voorafgande atan eventuele overplatsing naar de IBDKL voor militairen.

Instituut Keuring en Selectie voor de Krijgsmacht. Verricht voor de krijgsmachten de selectie en medische aanstellingskeuring.

Bedrijisarts (in opleiding) in dienst van het IKS die de medische aanstellingskeuring effectief verricht.

Peace-keeping missie in Kosovo 1999-2000.

Koninklijke Landmacht.

Koninklijke Lachtmacht. 
KM

KMA

KMar

KMS

MGO

Milicien

MKR

Natres

PAGO

Paraatstelling

PBGO

Peace-enforcing missie

Peace keeping missie

Pensioenkeuring

$\mathrm{PGO}$
Koninklijke Marine.

Koninklijke Militaire Academie, opleidingsinstituut voor officieren $\mathrm{KL}$.

Koninklijke Marechaussee, militaire politie.

Koninklijke Militaire School, opleidingsinstituut voor onderofficieren $\mathrm{KL}$.

Zie pensioenkeuring.

Frans, "soldaat van een lichting".

Militair Keuringsregelement. Dit reglement vormt de grondslag voor de uitvoering van zowel de annstellingskeuring als de pensioenkeuring of $\mathrm{MGO}$ voor militairen, evenals dit voorheen voor het PGO het geval was.

Korps Nationale Reserve. Parttime vrijwillig dienenden, die louter bimen de landsgrenzen worden ingezet in geval van een grootschalig conflict.

Periodiek Arbeidsgezondheidkundig Onderzoek.

Parate plaatsing. Het op de eigen functie bij een bepaald onderdeel plaatsen van de militair na het doorlopen van de opleiding(-en).

Periodiek Bedrijfsgezondheidkundig Onderzoek.

Militaire operatie on de vrede in een gebied af te dwingen met militaire middelen.

Militaire operatie met als doel om de vrede in een gebied te handhaven.

(commissoriaal) Geneeskundig onderzoek volgens het Besluit Procedure Geneeskundig onderzoek blijvende dienstongeschktheid en pensioenkeuring militairen, Statsblad 1997,67.

Periodiek Geneeskundig Onderzoek. Periodieke (om de vijf jaar) beoordeling van de dienstgeschiktheid op medische gronden voor beroepsmilitairen. Het PGO werd bij de KL uitgevoerd van $1960 \mathrm{t} / \mathrm{m} / 1995$. 
Proportionaliteitcriterium

PULHEEMS

$\mathrm{RBB}$

SFOR

Subsidiariteitcriterium

SZW

Uitslaggevend arts

UNELCYP

UNMEE

VGDKL

$\mathrm{VO}_{2} \max$

WMK
Een onderzoek is alleen gerechtwardigd indien de prevalentie van de te onderzoeken aandoening bij onderzoekspopulatie dit rechtvandigt .

Indeling na aanstellingskeuring bij het Canadese Leger in 1945 naa: : Physical capacity, Upper limbs, Locomotion, Hearing, Eyesight, Emotional and Mental.

Rijksbedrijfsgezondheids- en Bedrijsveiligheidsdienst. Naam van de toenmalige Arbo-dienst voor overheidspersoneel uit de tijd van het onderzoek van De Kont (1992).

Het te verrichten onderzoek moet relevant zijn voor het verwezenlijken van het doel van de keuring.

Speciale opleidingseenheid om leerlingen die op medische of sociale gronden de AMO tijdelijk niet geheel kunnen volgen, op te vangen.

Tot op heden doorlopende peace keeping missie in Bosmiè-Herzegowina.

Een onderzoeksmethode moet zo weinig mogelijk belastend of ingrijpend voor de keurling zijn.

Ministerie wan Sociale Zaken en Werkgelegenheid.

Seniorbedrijfsarts in dienst van éen van de Arbo-diensten van de krijgsmachtdelen, die niet de aanstellingskeuring zelf uitvoert, mar nadien de uitslag vaststelt.

Peace keeping missie in Cyprus t/m 2001.

Peace keeping operatie in Erithrea 2001.

Eenheid waar onder meer voor militairen van zowel de $\mathrm{KL}$ als de KMar de pensioenkeuring en het IGO worden uitgevoerd.

Maximale zuurstofopname, gemeten in $\mathrm{ml} / \mathrm{kg}$ lichamsgewicht / minuut.

Wet op de Medische Keuringen. 
172 


\section{Samenvatting}

Vanuit de behoefte om een goede voorspelling te doen van de inzetbaarheid van militairen, is een valideringsonderzoek [1] uitgevoerd. In dit onderzoek is de kwaliteit van een nieuw ontwikkeld keuringssysteem vergeleken met de kwaliteit van het voorheen gebruikte keuringssysteem.

In hoofdstuk 1 worden achtereenvolgens weergegeven: de niet-systematische en systematische waarnemingen, de ontwikkeling van een nieuw instrument voor keuringen, de theorie en de daaruit gededuceerde onderzoekshypothese, de onderzoeksvragen en het de hoofdlijnen van het materiaal en de methoden die gebruikt zijn om deze onderzoeksvragen te beantwoorden.

De niet-systematische warnemingen bestonden uit de ontdekking dat er kwaliteitscriteria voor het instrument "keuringen" bleken te bestaan [2] en de confrontatie met de vraag of keuringen bij de Koninklijke Landmacht ooit aan die criteria waren getoetst. Op grond van deze niet-systematische waarnemingen was de interesse in het onderwerp, te weten de kwaliteit van (anstellings-) keuringen zoals uitgevoerd bij de KL, gewekt. Deze interesse leidde tot systematische waarnemingen. Eerst werd nagegaan waarop de werkwijze voor het uitvoeren van keuringen bij de $\mathrm{KL}$ was gebaseerd en of die werkwijze tekortkomingen vertoonde.

Nadat Holland in 1810 bij het Franse keizerrijk was ingelijfd en Napoleon Bonaparte ook hier in 1811 de conscriptie had laten invoeren, werd alhier het eerste (Franse) reglement op het geneeskundig onderzoek van miliciens van kracht. Dit reglement vormt de grondslag van het Militair Keuringsreglement (MKR), dat sedertdien bij de Koninklijke Landmacht als basis dient voor zowel de medische aanstellingskeuring als de pensioenkeuring voor militair personeel. Bij dat MKR behoorde van oudsher een "Lijst van Ziekten en Gebreken". De keurend arts besliste op grond van professionele autonomie of een rekruut in voldoende emstige mate aan één der in deze lijst vermelde ziekten of gebreken leed, wat inhield dat deze moest worden afgekeurd. Na de Tweede Wereld- 
oorlog werd door de Nederlandse regering de ABOHZIS-classificatie ${ }^{l}$ van het Canadese leger overgenomen. Dit classificatiesysteem ter nadere verfijning van het selectieproces werd vervolgens aan het MKR en de "Lijst van ziekten en gebreken" gekoppeld. Hierdoor werd de professionele autonomie van de keurend arts sterk ingeperkt. Met dit keuringssysteem is tot november 1998 gewerkt.

De tweede systematische waarneming bestond uit literatuuronderzoek naar de kwaliteit van keuringen. Uit dit onderzoek kwam naar voren dat de kwaliteit van het instrument keuringen over het algemeen te wensen over liet. Vermoedelijk gold dit ook voor het in de KL gebruikte systeem. Dit keuringssysteem was diagnosegericht en niet gebaseerd op het model "belasting-belastbaarheid" [3]. Er bestonden geen functie-eisen. Het classificatiesysteem was niet aangepast, alhoewel de taakstelling van de krijgsmacht was uitgebreid met operationele uitzendingen naar het buitenland. Op deze wijze voldeed het systeem niet aan de eisen die de Wet op de Medische Keuringen (WMK, 1998) stelt.

De derde systematische waarneming bestond uit het uitvoeren van onderzoek naar de reproduceerbaarheid van keuringen binnen de $\mathrm{KL}$, waaraan in hoofdstuk 2 aandacht wordt besteed.

Vanuit deze waarnemingen werd de theorie geïnduceerd dat de kwaliteit van bestaande aanstellingskeuringen niet voldeed. De Bevelhebber der Landstrijdkrachten (BLS) werd in 1997 geadviseerd om een ander keuringssysteem te laten ontwikkelen. Als basis hiervoor dienden de recent geformuleerde werkgeverseisen, minimaal te stellen aan alle militairen. Deze eisen werden geformuleerd op grond wan de concrete militaire takstelling, met inbegrip van operationele uitzendingen naar het buitenland. Dit leidde tot een lijst met 43 beoordelingspunten. Elk beoordelingspunt werd voorzien van een grenswaarde: de Basismedische Eis KL (BMEKL). Tijdens de keuring wordt onderzocht of de kandidaat beperkt is ten opzichte van deze eisen. Om de keuringsituatie te structureren zijn keuringsprotocollen ontwikkeld.

In tegenstelling tot het oude ABOHZIS-systeem voldeed het nieuwe BMEKL-systeem aan de eisen, gesteld door de WMK. Hypothetisch zou dit moeten betekenen dat de kwaliteit van het BMEKL-keuringssysteem beter zou moeten zijn dan die van het ABOHZIS-systeem.

1 De letters ABOHZIS stonden voot Alyemene fysieke toestand, Bovenste extremiteiten, Onderste extremiteiten, Horen, Zien, Intelligentie en Stabiliteit, de terreinen warop werd ingedeeld, net en gradatie van 1 (geen ziekte of gebrek) tot 5 (ongeschikt op grond wan.... 
Omdat voor de beoordeling van de kwaliteit van keuringsystemen geen gouden standaard voorhanden is, resteende alleen de mogelijkheid on het ane keuringssystem te vergelijken ten opzichte van het andere. Het BMEKL-keuringssysteem zou per 1 november 1998 het ABOHZIS-systeem gaan vervangen. Dat bood de gelegentheid om deze beide keuringsystemen kwalitatief met elkaar te vergelijken.

Met inachtneming van deze kennis en de hypothese werden hierna de volgende onderzoeksvragen geoperationaliseerd:

1. Voldoet de reproduceerbaarheid van het nieuwe keuringssysteem bij de pensioenkeuring aan de normering die gebruikelijk is voor screeningstesten?

2. Hoe verhoudt zich de mate van overeenstemming tussen beide keuringsystemen bij de aanstellingskeuring?

3. Is er een verschil in prognostische warde tussen beide keuringssystemen ten aanzien van de geschikt verklaarde militairen BBT op het gebied van de dagen inzetbaartheid en/of de genoten medische consumptie?

4. Indien een verschil in prognostische warde tussen beide keuringssystemen wordt gevonden, kan het mechanisme daarvan worden verklaard door analyse van de determinanten persoonskenmerken, de eigen belewing van gezondheid, inzetbaaheid en operationele inzet?

5. Bestaat er ook een verschil in prognostische waarde tussen beide keuringssystemen ten aanzien van uitsluitend de uitgezonden militairen en zo ja, kan dat worden verklaard door analyse van de determinanten persoonskenmerken, het beleven van de eigen gezondheid, de eigen beleving van gezondheid en inzetbarheid?

Om deze vragen te beantwoorden is een gerandomiseerde gecontroleerde studie uitgevoerd. In deze studie zijn 352 soldaten gedurende twee jar gevolgd, nadat ze waren goedgekeurd volgens éen wan beide keuringsystemen.

Als effectvariabelen werd gekozen voor zowel inzetbarheid thet anat dagen dat een militair geen arbeidsverzuim vertoont) als de medische consumptie gedurende de onderzoeksperiode. Alleen voor het beantwoorden van de eerste onderzoeksvraag diende een andere onderzoekspopulatie te worden gebruikt.

In hoofdstuk 2 wordt nader ingegan op de in de inleiding vermelde derde systematische warneming. In dit hoofdstuk wordt de mate van overeenstemming onderzocht in de eerste plaats tussen de ABOHZIS-classificaties, vervolgens tussen de medische beperkingen, en als latste tussen die classificatie en de beperking. Voor dat doe] werden 24 casus afkomstig van het periodiek geneeskundig onderzoek (PGO) geanonimiseerd. Vervolgens werd aan twee artsen verzocht om zowel een $A B O H Z 1 S$-classificatie op te maken als in voorkomend 
geval medische beperkingen op te leggen. Alhoewel de uitkomsten niet altijd als onvoldoende kumen worden gekenschetst, corresponderen de resultaten toch met eerdere teleurstellende resultaten uit studies van anderen [2]. De conclusie is dat door de ABOHZIS-classificatie te handhaven niet langer an de huidige behoeften wordt voldaan.

In hoofdstuk 3 wordt het onderzoek naar is de reproduceerbaarheid van het nieuwe keuringssysteem tijdens de pensioenkeuring weergegeven. 30 geanonimiseerde keuringsdossiers met een evenredige verdeling tussen geschikt en ongeschikt verklaarden werden ter beoordeling voorgelegd aan twee seniorbedrijfsartsen. Voor het meten van de overeenstemming werd gebruik gemaakt van twee maten: de kappa [1] en PD\% [2]. Het resultaat is dat er, voor wat betreft het geschiktheidoordeel, sprake is van een goede overeenstemming [1]. De conclusie is dat het nieuwe keuringssysteem bij de pensioenkeuring voldoet aan de normering die gebruikelijk is voor diagnostische testen.

In hoofdstuk 4 wordt het onderzoek naar de mate van overeenstemming tussen beide keuringssystemen bij de aanstellingskeuring weergegeven. Hiervoor werd aan dezelfde bedrijfsartsen die voor de oorspronkelijke keuringsuitslag verantwoordelijk waren, na ongeveer $1 \frac{1}{3}$ jaar gevraagd om 227 keuringsdossiers te herbeoordelen. De dossiers waren geanonimiseerd en afkomstig van de gerandomiseerde, gecontroleerde studie waarvan in de hoofdstukken 5,6 en 7 sprake is. Voor het meten van de overeenkomst werd van 4 verschillende maten $[1,2]$ gebruik gemaakt. Op grond van de gevonden resultaten wordt geconcludeerd dat de inter-waarnemers overeenstemming bij de aanstellingskeuring voor beide keuringssystemen als voortreffelijk [1] kan worden beschouwd.

In hoofdstuk 5 worden beide keuringssystemen met elkaar vergeleken op hun vermogen om geschikte kandidaten op te leveren. Voor dit laatste worden de effectvariabelen dagen inzetbaarheid en medische consumptie gehanteerd. Er werd een gerandomiseerde, gecontroleerde studie verricht, waarbij 352 soldaten gedurende twee jaar zijn gevolgd, na geschikt te zijn verklaard en de militaire opleiding te hebben gevolgd.

De alanstellingskeuring blijkt de dominante factor te zijn bij het voorspellen van zowel het aantal dagen inzetbaarheid als de medische consumptie. Degenen, gekeurd volgens die door het BMEKL-systeem, blijken gemiddeld statistisch significant een hoger aantal dagen inzetbaar te zijn geweest (648 tegenover 612) en tegelijkertijd een lagere medische consumptie te vertonen ( 396 tegenover 746). In deze studie bleek het niet mogelijk om het mechanisme op grond warvan het BMEKL-systeem betere uitkomsten laat zien, te ontdekken. Voor- 
lopig wordt dit mechanisme verklard op basis van het verschil tussen beide keuringssystemen.

Hoofdstuk 6 wordt analyse gepleegd, teneinde het mechanisme te ontdekken warop de associatie tussen het soort keuringsysteem en de twee uitkonstmaten wit het vorige onderzoek berust. Gedurende het onderzoek zijn uiteenlopende data omtrent de deelnemers aan de studie verzameld (opleiding; uitzending etc.) Gedurende de onderzoeksperiode is tevens vijf maal een vragenlijst aan de onderzoekspersonen voorgelegd. Deze vragenljyst was inhoudelijk voor een deel gebaseerd op de vragenlijst die lang in Nederland is gebruikt bij het Periodiek Bedrijfsgezondheidkundig Onderzoek. De volgende factoren bleken een statistisch significante associatie met inzetbaarheid en medische consumptie te vertonen: schoolopleiding, blessures, operationeel ingezet worden en de mate waarin men zichzelf geschikt acht tot het unitwoeren van specifieke militaire vaardigheden. De betere prestatie van het BMEKL-systeem lijkt deels te kunnen worden toegeschreven aan het betere vermogen om op geschiktheid voor militaire takspecifieke eisen te keuren. Desalniettemin blijft opnieuw het primaire mechanisme verborgen.

Ondat het feit of men al dan niet wordt uitgezonden invloed uitoefent op de inzetbaarheid, worden in hoofdstuk 7 dezelfde analyses gepleegd als in de voorgaande hoofdstukken 5 en 6, mar nu alleen gericht op militairen uit beide studiegroepen die operationeel zijn ingezet in het kader van een uitzending. De betreffende militairen werden gedurende twee jaar gevolgd. Alls effectvariabelen werden opnieuw het aantal dagen inzetbaarheid en de medische consumptie gehanteerd. Daarnaast werd gebruik gemaakt van de halfjarlijks toegezonden vragenlijsten. Uit dit onderzoek komt naar voren dat uitgezonden militairen, gekeurd volgens het functiegerichte BMEKL-systeem, een grotere inzetbar heid vertoonden dan de uitgezonden militairen, gekeurd volgens het diagnosegerichte ABOHZIS-systeem. Het BMEKL-keuringssysteem voorspelt beter dan het ABOHZIS-systeem ten aanzien van het functioneren als militair in het algemeen, en specifiek op het gebied wan witzending, gezondheid en bewegingsapparaat.

In hoofdstuk 8 wordt de slotbeschouwing weergegeven. Nabeschouwing van de onderzoeken levert een aantal kanttekeningen op, sommige daarvan hebben invloed op het uiteindelijke antwoord op de onderzoeksvragen. Ten eerste is het onderzoek beperkt gebleven tot het beoordelen van de inter-warnemers variatie. Ten tweede is het nieuwe BMEKL-keuringssysteem een betere voorspeller dan het $A B O H Z I S-S y s t e e m$, maar het mechanisme warop dit is gebaseerd kan 
niet worden aarigetoond. Dit impliceert dat delen van sommige vragen (reproduceerbaar woor zover het de inter-waarnemers variatie betreft; factoren die het opgetreden verschil beinvloeden kunnen niet worden verklaard) niet kunnen worden beantwoord. Tegellijk wordt de bewijslast eenvolgende onderdelen van deze studie, als voldoende beschouwd om te stellen dat de hypothese juist is geweest. Het feit dat de hypothese wordt aangenomen, leidt tot de vraag of de theorie inzake keuringen moet worden aangepast. Ex kunnen werschillende verklaringen worden aangedragen om het wellicht alleen ogenschijnlijke - verschill tussen hypothese en theorie aannemelijk te maken. Voor alle verklaringen geldt evenwel dat zij alleen op grond van deze studie worden weergegeven. Bouter en van Dongen [1] stellen dat de resultaten van één enkel onderzoek een theorie zelden kunnen maken of breken. In feite, zo stellen zij, is er een empirische spiraal nodig om de werkelijkheid steeds nauwkeuriger te beschrijven Ten gevolge van deze constatering lijkt een aanpassing van de theorie prematuur. $O m$ in het kader van de empirische spiraal te onderzoeken of de theorie in de toekomst wellicht toch moet worden aangepast, wordt besloten met enige aanbevelingen voor verder onderzoek.

\section{Geraadpleegde literatuur}

1. Bouter LM, Dongen MCJM van: Epidemiologisch onderzoek, opzet en interpretatie. Bohn, Staffeu en van Loghum. Houtenn 1995.

2. Kort WLAM de: Personnel selection through pre-employment medicals. Ansterdam, 1993.

3. Dijk FjH van, Dormolen $\mathrm{M}$ wan, Kompier MAJ et al: Herwardering model belastingbelastbaarlieid. "TSG, 1990;68: 3-10. 


\section{Abstract}

The necessity for a good prediction of the fitness for duty of soldiers from the Royal Netherlands Army (RNLA) has led to a validation study [1]. In this study the quality of a new developed medical pre-employment assessment is compared to the quality of the previous used system.

Chapter 1 contains: the non-systematic and the systematic observations, the development of a new instrument for medical assessment, a theory and, deduced from that theory, a hypothesis, the study questions and the main features of both material an methods, used to answer these study questions. The non-systematic observations were the discovery that criteria existed with which to measure the quality of the instrument of medical assessment [2], as well as the confrontation with the question as to whether the quality of the medical assessments as conducted in the RNLA had ever been measured against those criteria. As a result of these non-systematic observations, the interest in the quality of medical (pre-employment) assessments, as conducted within the RNLA, was evoked. That interest led to systematic observations being made. First, the method of conducting medical assessments within the RNLA was studied, as well as the question as to whether this method showed any shortcomings.

Following the incorporation of the Kingdom Holland into the French Empire in 1810, and the introduction by Napoleon Bonaparte of conscription in 1811, the first (French) regulation on medical assessment of conscripts came into force also here. This regulation is the foundation of the "Regulations for Military Medical Examinations", which from that day on have been used by the RNLA as a basis for pre-employment medical assessments as well as medical assessments in the event of a pension claim.

Ever since their introduction, the "Regulations for Military Medical Examinations" have been accompanied by a "List of Diseases and Infirmities". It was left to the professional autonomy of the physician performing the examination to decide whether a recruit was suffering from any disease or infirmity mentioned in this list severely enough to be declared unfit for military service. 
After the Second World War the Dutch government adopted the PULHEEMS ${ }^{1}$ classification method used by the Canadian army, known in Dutch as the ABOHZIS system. This classification system for further refinement of the personnel selection process was combined with the "Regulations for Military Medical Examinations" and the accompanying "List of Diseases and Infirmities". The professional autonomy of the physician performing the examination was thus reduced. This system remained in place until November 1998.

The second systematic observation was a literature study regarding the quality of medical assessments. The conclusion from that research was that the quality of the instrument "medical assessments" in general was poor. This was presumably also the case with the system used within the RNLA. This system was diagnosis-related and not based on the "workload-capability" model [3]. Job requirements did not exist. The classification system was not changed even though the tasks of the armed forces had recently been expanded to include missions abroad. Thus the system was not in keeping with the Medical Examinations Act of 1998.

As a third systematic observation a study was performed to investigate the reproducibility of medical assessments in the RNLA, as will be explained in further detail in Chapter 2.

From these observations the theory was induced that the quality of existing medical pre-employment assessments was insufficient.

The Commander-in-Chief of the Army was advised in 1997 to have a new system for medical assessment developed. As a basis for that further development the recently defined employer's requirements were used, which applied minimally to every soldier. These requirements were developed according to the actual military tasks, including deployment on missions abroad. Thus a list of 43 assessment criteria for physical examination was developed. For each criterion we defined a minimum, which we called the "RNLA Basic Medical Requirements" (BMEKL in Dutch). During the examination the physician checks whether the candidate has a restriction with regard to these requirements. In addition, we developed protocols to give structure to the medical assessments. Unlike the old ABOHZIS system, the new BMEKL system was in keeping with the Medical Examinations Act of 1998. Hypothetically, this should lead to a better quality of the BMEKL system in comparison with the old system. Since

1 "The letters of the Dutch acronym $A B O H Z I S$ stand for; $A=$ physical capacity, $B=$ tupper limbs, $O=$ lower limbs, $H=$ hearing, $Z=$ eyesight, $I=$ mental state, $S=$ emotiond state, which are the terms used for classification, graded from 1 (no disease or infirmity) to 5 (unfit due to...). 
there is no "golden standard" for pre-employment medical assessment to compare it with, the only remaining possibility was to compare the quality of the two systems mentioned above. The BMEKL system was to replace the ABOHZIS system in November 1998, which provided the opportunity to compare the quality of both systems. Based on this knowledge and the hypothesis, the following study questions were developed:

1. Does the reproducibility of the Basic Medical Requirements meet the standards commonly used for diagnostic tests, when used for assessments related to pension claims?

2. How does the reproducibility of both systems compare for pre-employment medical assessments?

3. Is there a difference in the prognostic value between the two systems for pre-employment medical assessment when looking at the amount of time fit-for-duty and/or the health care costs incurred, once a candidate has been declared fit for active service?

4. If a difference in the prognostic value between the two systems for pre-employment medical assessment is found, can this be explained by analysing the following determinants: personal characteristics, the personal experience of health and fitness for duty as well as being deployed or not?

5. Is there also a difference in the prognostic value between the two systems for pre-employment medical assessment when looking only at those persons who have actually been deployed on a mission abroad, and if so, can that difference be explained by analysing the following determinants: personal characteristics, the personal experience of health and fitness for duty?

To answer these questions, a randomised-controlled study was performed. In this study 352 soldiers were monitored for two years after being declared fit by one of the pre-employment medical assessment systems in question. Both the fitness for duty of military personnel (the number of days a soldier is not absent from work) and the health care costs incurred during the research period were chosen as the effect variables. Only for the first question was it necessary to use another study population.

Chapter 2 discusses the third systematic observation, as mentioned in the introduction. The reproducibility was investigated, first of the ABOHZIS classification, then of the medical restrictions and finally the reproducibility of the combination of both classification and restrictions. For that purpose 24 cases as used at the time for the periodical medical assessment were made anonymous. Two occupational health physicians were asked to apply the ABOHZIS classification and if needed the medical restrictions to each case. Although the results 
of this study cannot always be defined as insufficient, they correspond well to earlier disappointing results of other studies [2]. The conclusion is that the ABOHZIS classification no longer meets the demands of our time.

Chapter 3 studies the reproducibility of the Basic Medical Requirements with regard to the new system of medical assessments when used for pension claims. Thirty medical files were made anonymous. In 15 cases the candidates were declared to be fit-for-duty, in the other 15 cases the candidates were declared to be unfit. Then two occupational health physicians of the RNLA were asked to re-examine these cases on the basis of the medical files. To analyse the agreement two measures were used: the agreement according to kappa [1] and PD\% [2]. In the case of the fit-for-duty declaration the reproducibility appears to be good [1]. Therefore the conclusion was that the reproducibility of the Basic Medical Requirements, used for medical assessment regarding a pension claim, meets the standards commonly used for diagnostic tests.

In chapter 4 the reproducibility of the results of the pre-employment medical assessment was examined. The three occupational health physicians who were responsible for the original declarations were asked to re-examine 227 cases, approximately $1 \frac{1}{2}$ years later. These cases were 227 anonymous medical files from the randomised-controlled study as described in chapters 5 and 6 . To analyse the agreement four different measures $[1,2]$ were used.

According to the results of this study, the inter-observers variation can be described as excellent [1] for both pre-employment medical assessment systems.

In chapter 5 the two different examination systems were compared for their ability to identify suitable recruits. For that latter purpose we used the two operational measures of days fit-for-duty and health care costs. A randomised-controlled study was performed, in which 352 soldiers were monitored for two years after being declared fit by one of the pre-employment medical assessment systems in question and having passed their General Military Training. The pre-employment medical assessment system was found to be the dominant factor for predicting the number of days fit-for-duty as well as the health care costs incurred. Those declared fit by the new BMEKL system showed a statistically significant higher mean number of days fit-for-duty $(648$ compared to 612) and incurred significantly lower mean health care costs ( $€ 396$ compared to 6746 ). In this study it was not possible to uncover the mechanism by which the BMEKL examination system led to an improvement in outcome. For the time being this mechanism has been explained on the basis of the differences between the two systems. 
In chapter 6 an analysis was performed to uncover the mechanism on which the association between the two systems of assessment and the two measures of outcome depends. During the study, divergent data about the subjects of the study have been collected (training, on mission abroad etc.). Also, the soldiers were asked five times to complete a questionnaire, its content based in part on a periodic occupational health examination questionnaire commonly used in the Netherlands. The following factors showed a statistically significant association with fitness for duty and health care costs: education, injuries, actual operational deployment and the extent to which the soldiers considered themselves able to perform specific military skills.

The superior performance of the new BMEKL system seems partly due to the better ability of assessing to meet the military task-specific requirements. However, the primary mechanism remains as yet undiscovered.

Because being deployed on a mission is associated with fitness for duty, in chapter 7 the same analyses are performed as in chapters 5 and 6 , but this time restricted to those soldiers from both study groups who had been deployed on a mission abroad. In this study those soldiers were monitored for two years, using the two operational measures: number of days being fit for duty and health care costs. In addition, during the study period the candidates were given a questionnaire twice a year. The study revealed that the soldiers who were deployed on a mission and assessed using the job-based BMEKL system, displayed a greater fitness for duty than those assessed using the diagnosis-based ABOHZIS system. The BMEKL assessment system is a better predictor, with regard to the ability to function as a soldier in general and with regard to deployment, health and the locomotor apparatus in particular, than the ABOHZIS system.

In chapter 8 the concluding remarks are made. A final consideration of the studies leads to a number of remarks, some of which may influence the final answers to the study questions. Firstly, only the inter-observers variation was studied. Secondly, the new BMEKL system is a better predictor than the old ABOHZIS system, but the primary mechanism remains undiscovered. This implies that parts of some study questions (reproducibility measured only in terms of the inter observers variation; no explanation as to why some factors are responsible for the differences) cannot be answered. Yet the cvidence, gathered from the various parts of this study, is considered to be sufficient to accept the hypothesis. Accepting the hypothesis raises the question as to whether the theory on the subject of assessments should be adapted. Several explanations can be found to make the - possibly only apparent - difference between this hypothesis and the theory acceptable. All those explanations, however, only apply to 
the present study. According to Bouter and Van Dongen [1] the results of one single studly seldom change a theory. In fact they state that an empirical spiral is necessary to describe reality more accurately each time. Therefore, changing the theory would seem premature. It would require further research to find out whether, according to the empirical spiral, the theory should be adapted in the future. This chapter concludes with several recommendations for such research.

\section{References}

1. Bouter LM, Dongen MCJM van: Epidemiologisch onderzoek, opzet en interpretatie. Bohn, Stafleu en van Loghum. Houten, 1995.

2. Kort WLAM de: Personnel selection through pre-employment medicals. Amsterdam, 1993.

3. Dijk FJH wan, Dormolen $M$ van, Kompier MAJ et al: Herwardering model belasting-belastbartheid. TSG, 1990; 68:3-10. 


\section{Nawoord}

Bij de totstandkoming van dit proefschrift heb ik van veel mensen ondersteuning mogen ontvangen. Die ondersteuning was uiteenlopend van vorm; telkens heb ik daaraan motivatie en inspiratie ontleend. Op het gevaar af dat ik iemand vergeet te vermelden, wil ik daarom hieronder iedereen bedanken die mij de afgelopen jaren heeft ondersteund.

Ik bedank de collega's waarmee ik de Basismedische Eisen heb ontwikkeld. In de eerste plaats Jeroen Peters - medeauteur van het artikel waarop hoofdstuk 3 is gebaseerd - en voorts Ed Hendriks, Hans de Boer, Tjeerd Homsma, Erik Peperkamp en John van Meeteren, voor de prettige en succesvolle samenwerking in 1997.

Voorts bedank ik de collega's in de periode $1998-2000$ werkzaam waren als uitslaggevend arts bij het Instituut Keuring en Selectie (IKS), voor hun medewerking: Ronald de Groot, Theo van der Snoek ${ }^{\dagger}$ en Remco Holst. Evenzeer gaat mijn dank uit naar alle keurend artsen van het IKS uit die periode, voor hun medewerking.

Mijn dank gaat verder uit naar Evert van Ankum, de toenmalige Commandant van het Militair Geneeskundig Facilitair Bedrijf, voor het beschikbaar stellen van financiële ondersteuning. Ook wil ik Adri Blom, Wim Melger en alle medewerkers van het bureau Medisch en Paramedisch Personeel bedanken, voor hun behulpzaamheid bij het raadplegen van de personeelsbestanden. Ook Paulien Burema bedank ik voor al haar zoekwerk. Tevens gaat mijn dank uit naar Maarten Hoeienbos, die als geen ander iemand tot publiceren weet aan te zetten, evenals naar Dirk Kramer, voor zijn medewerking en morele steun.

In deze opsomming mogen beslist Joop de Lange en André Sondeijker niet ontbreken, voor hun gastvrijheid bij de redactie van het Nederllands Militair Geneeskundig Tijdschrift. Joop bovendien nog in het bijzonder bedankt voor zijn redactionele bijdrage. Ook bedank ik Thea van Manen en Onno Mulder, voor hun enthousiaste inzet waardoor telkens weer alle vragenlijsten halfjarlijks op hun bestemming terecht zijn gekomen.

Voorts bedank ik Ken Redekop, woor zijn onmisbare bijdrage. Evenzeer bedank ik Evert-Jan Slootman voor zijn steun en inspiratie. Ook mijn supericuren gedurende de onderzoeksperiode, Wil van der Water en Rob van der Meer, ben ik dank verschuldigd voor het beschikbaar stellen van "de baas zijn tijd".

Tot slot gaat mijn dank in het bijzonder uit naar mijn promotoren, Frans Nijhuis en Han Willems, die zich beiden leermeester in de ware zin des woords hebben getoond. 
186 


\section{Curriculum Vitae}

John de Raad is op 9 november 1956 in Dordrecht geboren. Na het Johan de Witt-gymnasium en het vervullen van de militaire dienstplicht heeft hij de studie geneeskunde gevolgd aan de Erasmus Universiteit Rotterdam. Als assistent werkte hij vervolgens twee jaar bij het St. Ignatius Ziekenhuis te Breda. In 1989 werd hij officier-arts bij de Koninklijke Landmacht. Tot op heden vervulde hij hier de volgende functies:

- Bataljonsarts in de rang van eerste-luitenant-arts bij het $41 \mathrm{e}$ Pantserinfanteriebataljon in Ermelo, 1989-1990.

- Hoofd Geneeskundige Instructiegroep in de rang van kapitein-arts aan het Opleidingscentrum Militair Geneeskundige Dienst te Hollandsche Rading, 1990-1992.

- Plaatsvervangend Hoofd Hygiëne Inspectie Orgaan in de rang van majoor-arts in de Luitenant-Generaal Knoopkazerne te Utrecht, 1992-1994.

- Seniorbeleidsmedewerker bedrijfs- en verzekeringsgeneeskunde bij de Directie Personeel en Organisatie, Cluster Gezondheidszorg, Afdeling Gezondheidszorg Beleid en Planning in Den Haag, in de rang van luitenantkolonel-arts, 1994-2004.

Momenteel is hij Hoofd van de Verzekeringsgeneeskundige Dienst KL te Utrecht in de rang van kolonel-arts.

Van 1990 tot 1993 volgde hij de postacademische opleiding in de Arbeids- en bedrijfsgeneeskunde, gevolgd door de postacademische opleiding in de Verzekeringsgeneeskunde van 1994 tot 1996, beide bij TNO/Preventie en Gezondheid te Leiden.

Gedurende het gehele onderzoeksperiode maakte John deel uit van de Koninklijke Landmacht. Het onderzoek zoals weergegeven in hoofdstuk 2 van dit proefschrift is in 1996 uitgevoerd en gepubliceerd. De opzet voor het onderzoek, weergegeven in de overige hoofdstukken, is in 1998 ontwikkeld en uitgevoerd.

In 1999 is hij als Senior Medical Officer in het kader van SFOR6 met het $12 \mathrm{e}$ Luchtmobiele Bataljon (Regiment Van Heutsz) naar Bosnië-Herzegowina uitgezonden.

De overige in dit proefschrift vermelde publicaties zijn in de jaren 1999-2004 tot stand gekomen.

Samen met Jeroen Peters en Frans Nijhuis ontving hij in 2000 de Talmapenning voor het artikel, weergegeven in hoofdstuk 3 van dit proefschrift.

John de Raad is gehuwd en vader van een dochter. 